UNIVERSIDADE DE SÃO PAULO

FACULDADE DE ARQUITETURA E URBANISMO

PROGRAMA DE PÓS-GRADUAÇÃO

KAREN PESSOA FREIRE

Quilombos nas bordas do ouro: conflitos entre negros e agentes lusitanos pelo domínio do Campo Grande no século XVIII

São Paulo

2020 


\title{
Quilombos nas bordas do ouro: conflitos entre negros e agentes lusitanos pelo domínio do Campo Grande no século XVIII
}

\author{
Versão Corrigida
}

\begin{abstract}
Dissertação apresentada à Faculdade de Arquitetura e Urbanismo da Universidade de São Paulo para obtenção do título de Mestre em Arquitetura e Urbanismo

Área de concentração: História e Fundamentos da Arquitetura e do Urbanismo
\end{abstract}

Orientação: Prof ${ }^{\mathrm{a}}$. Dr ${ }^{\mathrm{a}}$. Ana Cláudia Castilho Barone

São Paulo

2020 


\section{Ficha catalográfica}

Autorizo a reprodução e divulgação total ou parcial deste trabalho, por qualquer meio convencional ou eletrônico, para fins de estudo e pesquisa, desde que citada a fonte.

$$
\text { Catalogação na publicação }
$$

Serviço de Biblioteca e Documentação da

Faculdade de Arquitetura e Urbanismo da Universidade de São Paulo

Freire, Karen Pessoa.

Quilombos nas bordas do ouro: conflitos entre negros e agentes lusitanos pelo domínio do Campo Grande no século XVIII / Karen Pessoa Freire; orientadora, Ana Cláudia C. Barone - 2020 169 f. : il..

Dissertação (Mestrado em Arquitetura e Urbanismo) - Programa de Pós-Graduação em Arquitetura e Urbanismo, Faculdade de Arquitetura e Urbanismo, Universidade de São Paulo, São Paulo, 2020.Versão corrigida

1. Quilombos - Brasil. 2. Rede quilombola - Brasil. 3. Capitania de Minas Gerais. 4. Expansão territorial portuguesa no século XVIII - Minas Gerais. 5. Malha territorial - Minas Gerais. I. Barone, Ana Cláudia C., orientação. II. Título. 
FREIRE, Karen Pessoa. Quilombos nas bordas do ouro: conflitos entre negros e agentes lusitanos pelo domínio do Campo Grande no século XVIII. 2020. Dissertação (Mestrado em Arquitetura e Urbanismo) - Faculdade de Arquitetura e Urbanismo da Universidade de São Paulo, São Paulo, 2020.

Aprovado em:

\section{Banca Examinadora}

Prof. Dra.: Ana Cláudia Castilho Barone

Instituição: Faculdade de Arquitetura e Urbanismo da Universidade de São Paulo Julgamento:

Prof. Dra.: Íris Kantor

Instituição: Faculdade de Filosofia, Letras e Ciências Humanas da Universidade de São Paulo Julgamento:

Prof. Dra.: Fania Fridman

Instituição: Universidade Federal do Rio de Janeiro

Julgamento: 


\section{Quilombos nas bordas do ouro: conflitos entre negros e agentes lusitanos pelo domínio do Campo Grande no século XVIII.}

\section{RESUMO}

A zona que era conhecida como sertão do Campo Grande abrange áreas junto às nascentes dos rios São Francisco e Paranaíba e parte do rio Grande (nomes atuais), na fronteira entre as capitanias de Goiás, Minas Gerais e São Paulo, tendo sido palco de conflitos entre quilombolas e agentes da coroa portuguesa no século XVIII. Esta pesquisa busca compreender as características dos quilombos que povoavam tais paragens e procura, também, avaliar o processo de conquista das mesmas pelos súditos lusitanos, que buscavam novas terras para colonização e exploração de recursos naturais. Para isso analisamos registros de campanhas militares, organizadas pelo Estado português em meados daquele século, que apresentam mapas das regiões exploradas. Viabilizando a leitura espacial unificada desses mapas históricos, o trabalho transpõe a localização dos quilombos e outros dados deles extraídos para a cartografia atual. O exame dos documentos produzidos nos momentos de conflito entre quilombolas e luso-americanos nos revelam os critérios e estratégias de estabelecimento de povoamentos desses grupos, antagônicos em suas organizações sociopolíticas e culturais, que se rivalizaram pelo domínio desse planalto fértil e abundantemente irrigado. A partir das fontes primárias analisadas, constatamos que os quilombos do Campo Grande contavam com roças, pilões e manufaturas, possuíam diversificadas organizações sociopolíticas e estavam interligados uns aos outros, constituindo uma rede quilombola. Com arranjos político-sociais próprios, tais povoados eram combatidos pelos luso-americanos, que organizavam tropas armadas para eliminar esses inimigos da coroa portuguesa. Tais áreas foram apropriadas pelo Estado lusitano através da implantação de estradas, ranchos para descanso e abastecimento de tropas, fazendas e povoados destinados aos súditos da coroa Bragança sobre os quilombos que destruíam. Dessa maneira, tais quilombos podem ser compreendidos com precursores da malha territorial de parte da região que atualmente integra o "triângulo mineiro".

Palavras-chave: Quilombos. Rede quilombola. Capitania de Minas Gerais. Expansão territorial portuguesa no século XVIII. Malha territorial. 


\title{
Quilombos at the borders of gold mines: conflicts between blacks and Portuguese agents over Campo Grande territory in the XVIII Century.
}

\begin{abstract}
The region which used to be known as countryside of Campo Grande is the place of origin irrigated by several sources of São Francisco e Paranaíba Rivers (those are their current names), on the border between Goiás, Minas Gerais and São Paulo. Over the Eighteenth Century, quilombolas and agents from the Portuguese Crown disputed over those areas. This research aims to assess the main characteristics of the quilombos that existed in Campo Grande backlands. It also investigates that region's conquering process by Portuguese vassals, who sought new lands for colonization and the exploitation of natural resources. With this purpose, I analyze documents on Portuguese state's military expeditions in the midcentury, which comprise maps from the region to be explored. Enabling the unified spatial reading of these historical maps, this work also cross-references the ancient location of the quilombos and other information gathered from official documents with the recent cartography. The analysis of the documents, produced during the episodes of conflicts between quilombolas and Portuguese-Americans, reveals both groups' criteria and strategies for the land's settlement and occupation. With antagonistic sociopolitical and cultural organization, both groups competed for dominance of this fertile and abundantly irrigated plateau. The primary sources consulted indicate that Campo Grande quilombos were well equipped with plantations and manufacturing production, had diverse socio-political organizations and were interconnected to each other, constituting a quilombola community network. Such areas have been appropriated by the Portuguese State through the implementation of roads, ranches to rest and supply troops, farms and settlements destined to the vassals of the Crown Bragança over the quilombos they destroyed. Therefore, such quilombos can be understood as precursors of the territorial network of part of the region that currently integrates the Minas Gerais state.
\end{abstract}

Keywords: Quilombos. Quilombola community network. Captaincy of Minas Gerais. Portuguese territorial expansion in the XVIII ${ }^{\text {th }}$ Century. Territorial network. 


\section{AGRADECIMENTOS}

Este trabalho foi possível graças ao apoio das instituições de ensino, pesquisa e conservação que pude frequentar. Assim, agradeço o acolhimento pelo Liceu de Artes e Ofícios de São Paulo, pela Universidade Paulista e pela Universidade de São Paulo - cuja estrutura como um todo permitiu o desenvolvimento deste trabalho, especialmente pelas suas unidades da Faculdade de Arquitetura e Urbanismo (FAU-USP), da Faculdade de Filosofia, Letras e Ciências Humanas (FFLCH-USP) e do Instituto de Estudos Brasileiros (IEB-USP) pela Biblioteca Nacional (BNRJ), Arquivo Nacional (AN) e Instituto Histórico Geográfico Brasileiro (IHGB), cuja consulta aos arquivos no Rio de Janeiro foi financiada pela bolsa PROAP-CAPES.

Agradeço à professora Dra ${ }^{\mathrm{a}}$. Ana Cláudia Castilho Barone, junto a qual pude construir esta investigação, aos integrantes do Laboratório de Estudos sobre Relações Étnico-Raciais e o Espaço Urbano (LabRaça) da FAU-USP, grupo de pesquisa do qual participo. Agradeço pelas ricas observações ao trabalho, nas bancas de qualificação e de defesa, pelas professoras $D^{\mathrm{a}}$. Beatriz Piccolotto Siqueira Bueno, Dr ${ }^{\mathrm{a}}$. Maria Cristina Cortez Wissenbach, Dr ${ }^{\mathrm{a}}$. Fania Fridman e Dr ${ }^{\mathrm{a}}$. Íris Kantor.

Agradeço aos meus pais, marido, irmão, família, amigos e professores que veem me formando como pessoa e como profissional ao longo das décadas.

O presente trabalho foi realizado com apoio da Coordenação de Aperfeiçoamento de Pessoal de Nível Superior - Brasil (CAPES) -Código de Financiamento 001 


\section{LISTA DE ABREVIATURAS}

AHU Arquivo Histórico Ultramarino, Lisboa

AN Arquivo Nacional - Secretaria de Estado do Brasil, Rio de Janeiro

ANBNRJ Anais da Biblioteca Nacional, Rio de Janeiro

APM Arquivo Público Mineiro, Belo Horizonte

BNRJ Biblioteca Nacional - seção de manuscritos, Rio de Janeiro

IEB Instituto de Estudos Brasileiros da Universidade de São Paulo, São Paulo 


\section{LISTA DE ILUSTRAÇÕES}

Documento M01 -Mappa da Conquista do Mestre de Campos Regente Chefe da Legião Ignacio Correya Pamplona. [ca.1784]

Figura M01B - Estradas e povoados no Mappa da Conquista [.... ......

Documento M02 - [Mapa do trajeto da expedição de 1769 de Ignacio Correya Pamplona] [ca.1769]

Documento M03 - Mapa de todo o campo Grande tanto da parte da comquista, que parte com a Campanha do Rio verde e S. Paulo como de Piuhy cabeceyras do Rio de S. Francisco, e Goyazes. [176-].

Documento G01 - Quilonbo de hum dos braços da perdiçã̃. [1769?]

Documento G02 - Quilonbo chamado do Rio da perdiçã̃. [1769?] 94

Documento G03 - Quilonbo do Ambrozio. [1769?] 95

Documento G04 - Quilonbo da Sambabä̈a. [1769?] 96

Documento G05 - Quilonbo de Sam Gonçalo. [1769?] 97

Documento G06 - [Quilonbo] dos Santos fortes. [1769?] 98

Mapa K 01 - releitura da localização das povoações luso-americanas e quilombos sobre base cartográfica do IBGE editada. 118

Figura 01 - Perspectiva de mucambo e detalhes construtivos - Manuel Bandeira.

Figura 02 - Estrutura de paus a pique com varas amarradas - Sylvio Vasconcelos

Figura 03 - Planta e vista de residência em pau a pique - Antônio Luiz de Andrade

Figura 04 - "Habitação de negros" - Johann Moritz Rugendas

Figura 05 - Fazenda próxima à Província de São Paulo, desenho aquarelado - Thomas Ender 132

Figura 06 - "Senzalas" - Victor Frond 132

Figura 07 - "Antes da partida para a roça" - Victor Frond

Figura 08 - Mulheres Basoko fabricando potes, Alto Congo - coleção Mirac Tervuren 132

Figura 09 - Casas e sistema de vigilância de quilombo, Goiânia - Rafael S. A. dos Anjos 132 


\section{SUMÁRIO}

INTRODUÇÃO.

\section{Capítulo 1 - POVOS AFRODESCENDENTES NA CONSTRUÇÃO DO BRASIL E DE SUA HISTORIOGRAFIA}

1.1 - POVOS AFRICANOS EM TERRAS AMERICANAS 17

1.2 - JUÍZOS À PORTUGUESA NA CONSTRUÇÃO DA HISTORIOGRAFIABRASILEIRA

1.3 - NOTAS SOBRE O CONCEITO DE DIÁSPORA AFRICANA E SOBRE O IDEAL DE QUILOMBO PARA A IDENTIDADE CULTURAL E LUTAS POLÍTICAS NO BRASIL 22

1.4 - INTRODUÇÃO AOS ESTUDOS SOBRE QUILOMBOS. 29

1.4.1 - Primeiros trabalhos sobre quilombos na historiografia. 29

1.4.2 - O que são Quilombos e Mocambos. 30

1.4.3 - A heterogeneidade dos quilombos 31

1.4.4 - Relações entre quilombolas e outros grupos da sociedade ...... 31

1.4.5 - Composição social das tropas contra quilombos 33

1.4.6 - Quilombos nos sertões das minas no século XVIII. 34

1.4.7 - Considerações para os estudos dos quilombos setecentistas do Campo Grande 36

1.5 - EXPANSÃO DO IMPÉRIO LUSITANO NOS SERTÕES DAS MINAS SETECENTISTAS. 


\section{Capítulo 2 - MAPAS E RELATÓRIOS DE EXPEDIÇÕES AO CAMPO GRANDE}

ANÁLISE DAS FONTES PRIMÁRIAS.

2.1 - MAPPA DA CONQUISTA DO MESTRE DE CAMPOS REGENTE

CHEFE DA LEGIÃO IGNACIO CORREYA PAMPLONA [ca.1784]

2.1.1 - Título, assuntos, produção e cronologia do

"Mappa da Conquista [...]"

2.1.2 - Geografia

2.1.3 - Caminhos terrestres

2.1.4 - Caminhos, hidrografia, povoados e destacamentos militares

2.1.5 - Cronologia dos confrontos pelo povoamento e exploração do Campo Grande 48

2.1.6 - Considerações ao "Mappa da Conquista [...]" 54

Documento M01 - Edição do

“Mappa da Conquista do Mestre [...] Pamplona.

\section{2 - RELATÓRIOS DA EXPEDIÇÃO DE IGNACIO CORREYA}

PAMPLONA DE 1769

2.2.1 - A jornada de conquista do sertão do Campo Grande de 1769 segundo seus relatórios

2.2.2 - Estrada de Pamplona e picada velha de Goiás no "Memorial dos Mapas “ de 1769 68

2.2.3 - Considerações sobre o Diário, Memorial e Mapa do Trajeto da Expedição de 1769.

Documento M2 - Edição do [Mapa do trajeto da expedição de 1769 de Ignacio Correya Pamplona]. 72

2.2.4 - O interior dos quilombos do Campo Grande na visão de seus destruidores 75

Quilombo de hum dos braços da Perdiçaõ. 77

Quilombo chamado do Rio da perdiçaõ 79

Quilombo do Ambrozio 81

Quilombo da Sambabaÿa 83

Quilombo de Sam Gonçalo 86

Quilombo dos Santos fortes 89 
2.3.1 - Delimitação geográfica da zona do Campo Grande e expedições enviadas para sua conquista

2.3.2 - Expedições de Antonio Francisco França e de Bartolomeu Bueno do Prado entre 1756 e 1760.

2.3.3 - Povoações e estradas 103

2.3.4 - Meios de manutenção dos quilombos 106

2.3.5 - Considerações ao Mapa de todo o campo Grande [...] 107

\section{4 - CARTAS DA ADMINISTRAÇÃO PÚBLICA DA CAPITANIA} DE MINAS GERAIS

Documento - Carta de Gomes Freire para o vice-Rei de 1746

Documento - Carta do Conde de Bobadella para Tomé Joaquim da Costa Corte Real de 1759

\section{5 - TRADUÇÃO DOS MAPAS HISTÓRICOS PARA CARTOGRAFIA} ATUAL

Mapa K01 - Mapa atual com localização dos quilombos

\section{Capítulo 3 - QUILOMBOS E DISPUTAS TERRITORIAIS NO CAMPO GRANDE NO SÉCULO XVIII}

3.1- DEFINIÇÃO DE “QUILOMBO” E "NEGROS” SEGUNDO OS DOCUMENTOS OFICIAIS DAS REGIÕES MINERADORAS NO SÉCULO XVIII

3.1.1 - Quem são os "Negros" 119

3.1.2 - O que são os "Quilombos” 
3.3 - POSSÍVEIS ARQUITETURAS DOS QUILOMBOS DO CAMPO GRANDE NO SÉCULO XVIII ........................................................... 125

3.3.1 - Construções em madeira "a pique" e barro ....................................... 125

3.3.2 - Tipologias de moradias afro-americanas....................................... 127

3.3.3 - Arquitetura dos quilombos ........................................................ 133

3.4 - OS QUILOMBOS DO CAMPO GRANDE NOS RETRATOS DE SEUS INIMIGOS ...

3.4.1 - Roças, Pilões e Manufaturas

3.4.2 - Organização social, conexão entre quilombos, reedificação de povoados.

3.4.3 - Fortalezas e mirantes 143

3.4.4 - Rede quilombola no Campo Grande e meios de manutenção 146

3.5 - POVOAÇÕES NO CAMPO GRANDE NO SÉCULO XVIII

3.6 - POVOAÇÕES CONCORRENTES NAS BORDAS DO OURO

3.6.1 - Povoamento do Campo Grande e cercanias

3.6.2 - Expedições militares, estradas e ranchos para tropas

3.6.3 - Padroado régio e ocupação dos territórios americanos pelo Império lusitano

3.6.4 - Arraiais luso-americanos sobre territórios quilombolas 154

3.6.5 - Acesso à terra 155 


\section{INTRODUÇÃo}

A exiguidade historiográfica a respeito da influência dos povos africanos e seus descendentes na arquitetura e na conformação da malha territorial dessas partes da América foi o incômodo fundador que motivou esta pesquisa. Em busca de identificar expressões materiais das culturas das populações de ascendência africana nos territórios que vieram a constituir o Brasil (fossem na execução de suas moradias ou na organização de seus espaços de convívio), percebemos que os quilombos implantados nos arredores das áreas mineradoras no século XVIII seriam um interessante tema para o estudo.

Desejando vislumbrar algumas características espaciais dos quilombos setecentistas, assim como compreender suas inserções no território, examinamos alguns documentos oficiais de expedições militares organizadas pelo Estado português que exploraram a zona conhecida por eles como sertão do Campo Grande. Tais tropas luso-americanas combateram os habitantes ali estabelecidos, rivalizando com os quilombolas pelo domínio daqueles espaços.

Para a pesquisa selecionamos três documentos cartográficos onde os quilombos aparecem com destaque, o que nos permitiu localizar geograficamente as áreas de conflito entre quilombolas e agentes portugueses. Devido à riqueza de detalhes das narrativas e desenhos, elegemos como fonte primária principal desta pesquisa os relatórios da campanha de 1769, liderada por Ignacio Correya Pamplona. Arquivados na Biblioteca Nacional no Rio de Janeiro, pudemos analisar as imagens a partir dos manuscritos originais. No entanto, devido ao mau estado de conservação dos documentos, tivemos que acessar as narrativas que integram os relatórios a partir de sua publicação nos anais da instituição ${ }^{1}$.

Os dados levantados nos relatos da campanha de Pamplona foram confrontados com outros documentos do mesmo período, também executados por expedicionários lusoamericanos, que apresentaram os frutos de suas explorações no Campo Grande para o Estado português, onde a destruição de quilombos, a busca por ouro e por novas terras para agropecuária eram as principais atividades das tropas.

\footnotetext{
${ }^{1}$ [Encontrando Quilombos]. Transcrição e edição paleográfica por Maria Filgueiras Gonçalves. Anais da Biblioteca Nacional, Rio de Janeiro, v.108, p.47-113, 1988. Disponível em:

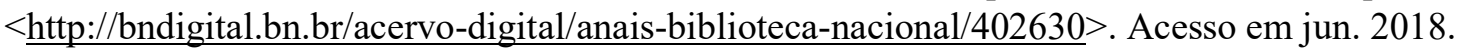


Priorizando tais documentos oficiais do Estado português como objetos de análise, a pesquisa também incorporou informações advindas de outros estudos, estabelecendo diálogo com a bibliografia já consolidada sobre o tema.

Visto que nossos arquivos guardam as heranças do Estado ibérico, os registros executados por grupos afastados do poder dominante raramente perduraram até nossos dias. Por essa razão, os documentos que hoje utilizamos para entrever aspectos da conformação material, espacial e sociopolítica dos quilombos, paradoxalmente, foram executados no momento de suas invasões e destruições pelos súditos da coroa lusitana. Além desses manuscritos traçados por seus inimigos, outro meio de aproximação aos vestígios dos povoados quilombolas que tivemos foi por meio das publicações dos estudos arqueológicos de um dos quilombos estudados.

Nosso acesso a esses povoados extintos ficam inevitavelmente atrelado aos registros executados por seus algozes. Contudo, através do exame dos próprios registros das expedições de combate aos quilombos, vemos que os ajuntamentos quilombolas analisados estavam bem estabelecidos no local, contando com roças de alimentos, produção de farinhas, teares, forjas de ferreiro, cemitérios, espaços para administração sociopolítica e capacidade para abrigar dezenas ou centenas de pessoas.

O episódio investigado revela a existência de um povoamento na região serrana junto às nascentes do Paranaíba e São Francisco onde predominavam indivíduos africanos ou descendentes, possivelmente associados a ameríndios, que concorreram contra os súditos lusitanos pelo domínio do Campo Grande ao longo de todo o século XVIII.

A análise dos documentos oficiais nos revelaram dados inesperados. Um deles foi a interligação entre os quilombos registrados nos documentos, onde alguns povoados tinham funções especializadas na organização das comunidades, que, por exemplo, podiam ter o plantio de alimentos em um quilombo e a administração sociopolítica em outro, constituindo uma rede quilombola. Outra surpresa foi a constatação da instalação da estrutura colonial do Estado português por sobre os quilombos destruídos, substituindo a povoação existente por outra subordinada à coroa lusitana.

A importância da rede quilombola naquelas paragens era tamanha que a implantação da estrutura do Estado português se sobrepôs à mesma na tentativa de suprimi-la, exterminando os quilombos e diluindo suas evidências através da construção de estradas, 
pousos para viajantes, fazendas, arraiais e patrimônios religiosos. Por ter servido de base para a estrutura luso-americana, que soterrou boa parte dos vestígios dos quilombos sob si, tal povoamento quilombola constituiu (involuntariamente) os alicerces da malha territorial assentada nessa região que hoje integra o triângulo mineiro.

Os objetos centrais deste estudo é a rede quilombola constituída no século XVIII nas regiões de nascentes da bacia dos Paranaíba e São Francisco e arredores (esboçando algumas características dos quilombos ali estabelecidos) e, a apropriação de seus territórios pelo Estado português com a instalação de sua estrutura sobre as terras quilombolas.

Algumas investigações que contribuiriam para a melhor compreensão dessas povoações concorrentes no Campo Grande não puderam ser empreendidas nesses 24 meses de pesquisa, como: realizar uma estimativa da população desses quilombos confrontando com as dos povoados luso-americanos vizinhos; traçar possíveis similaridades entre as conformações espaciais dos quilombos com povoados africanos ou ameríndios; realizar um inventário das sesmarias concedidas sobre terras quilombolas; investigar os povoados luso-americanos que se mantiveram ativos até nossos dias, cujas origens podem estar relacionadas aos quilombos (que parece ser o caso dos atuais municípios de Patrocínio e Bambuí). Seria também interessante analisar relatórios de outras expedições na região, assim como os registros da construção das estradas e malha territorial do entorno. Tais temas contribuiriam substancialmente para a compreensão da participação quilombola na formação do território, constituindo desdobramentos desta pesquisa que merecem ser retomados em outros trabalhos.

Como saldo desta investigação construída sobre os documentos oficiais, temos os quilombolas surgindo como desbravadores dos espaços sobre os quais posteriormente se estabeleceu a colonização do Estado português. Assim, tal esforço de reconstituição de fragmentos dessas comunidades extintas constitui também uma reflexão sobre o legado das populações quilombolas na conformação territorial da região que hoje faz parte do sudoeste de Minas Gerais.

A constatação da montagem da estrutura colonial portuguesa por sobre os quilombos nessa região, revelada através da análise dos documentos oficiais, nos faz questionar se podemos manter a perspectiva historiográfica que observa os agentes lusitanos como “colonizadores" e os povos indígenas como seus primitivos precursores, enquanto os povos 
de ascendência africana não teriam qualquer papel no estabelecimento da malha territorial. Tal ponto de vista nos parece incorreto.

Esta dissertação aborda, primeiramente, alguns aspectos gerais relevantes à pesquisa, progressivamente fechando o foco sobre os quilombos estudados e seus processos de conversão em plataformas de fixação de seus inimigos. No primeiro capítulo realizamos uma aproximação com temas relacionados aos quilombos e à expansão do domínio do Estado lusitano para o interior do continente americano a partir de fontes bibliográficas. No segundo capítulo destrinchamos alguns documentos da administração portuguesa setecentista (para os quais apresentamos também suas edições paleográficas), procurando fazer com que tais registros respondam nossas questões. Ainda no segundo capítulo exibimos o mapa atual que compomos para localização dos quilombos identificados na cartografia histórica. No terceiro capítulo confrontamos as diferentes fontes primárias e secundárias abordadas para examinar as características dos quilombos do Campo Grande e suas invasões por agentes portugueses. Nas considerações finais expomos um balanço sobre os tipos de povoados quilombolas implantados no Alto São Francisco, Alto Paranaíba, vale do Rio Gramde e arredores, assim como sobre a apropriação dos territórios quilombolas pelos vassalos da coroa portuguesa para o estabelecimento de sua malha colonial. 


\section{Capítulo 1 - OS POVOS AFRODESCENDENTES NA CONSTRUÇÃO DO BRASIL E DE SUA HISTORIOGRAFIA}

\section{1 - POVOS AFRICANOS EM TERRAS AMERICANAS}

Os povos distribuídos no continente africano são muito diversificados, tanto na multiplicidade biológica, organizações estatais e religiosas, práticas cotidianas, quanto na variedade ecológica dos ambientes habitados e formas de adaptação ao meio. Os estudos contemporâneos da África adotam recortes baseados em características físicas dos territórios (como tipos de cobertura vegetal, bacias hidrográficas e relevo), em macro grupos linguísticos e, também, nas formações estatais historicamente conhecidas ${ }^{1}$.

A maioria dos africanos que foram sequestrados de suas terras de origem para servirem como mão de obra escravizada na América do Sul entre o fim do século XVI e primeira metade do século XIX foram embarcados em portos da África Central (zona próxima à linha do equador, dominada por diferentes povos falantes de línguas com raízes comuns que nomeamos, generalizadamente, como povos Bantu²) e da África Ocidental (região ao sudoeste das bordas do Saara que compreende as áreas entre o rio Senegal e o rio Cross, onde está localizado o Golfo do Benin). ${ }^{3}$

Apesar dos esforços contemporâneos de levantamento e análise de dados sobre o tráfico atlântico negreiro, ainda não parece possível uma identificação precisa dos povos africanos que chegaram nessas partes da América do Sul. Boa parte dos prisioneiros capturados em diferentes partes do interior do continente africano por grupos rivais vizinhos ou por expedições caçadoras eram vendidos aos comerciantes de escravos locais e somente depois de percorrerem longas rotas, a pé ou em pirogas nos rios, que os cativos chegavam aos portos de embarque no litoral para serem novamente negociados e dali atravessarem o atlântico. $^{4}$

\footnotetext{
${ }^{1}$ M`BOKOLO, Elikia. África Negra: história e civilizações v.1. Salvador: EDUFBA; São Paulo: Casa das Áfricas, 2009. p.11-14/ p.49-53/ p.168-180.

${ }^{2}$ A forma de utilização entre os Bantu de prefixos classificadores junto aos nomes dos povos para indicar plural, singular e língua falada, foram extraída do artigo citado em: MUNANGA, Kabengele. "Origem e Histórico de Quilombo na África". Revista USP, São Paulo, n.28, p.56-63, mar.1996. Disponível em: http://www.revistas.usp.br/revusp/article/view/28364. Acesso em: dez. 2017.

${ }^{3}$ SOUZA, Marina de Mello. África e Brasil Africano. São Paulo: África, 2006. p.11-119.

${ }^{4}$ KI-ZERBO, Joseph. História da África Negra I. Sintra: Publicações Europa-América, 1972. p.2932/ p.22-126/ p.139-141/ p.172-416
} 
Mesmo os registros de origem dos portos de embarque do tráfico transatlântico não são precisos, visto que os comerciantes negreiros os burlavam quando restrições legais os constrangiam na realização do comércio humano em suas regiões de atuação. Por fim, os cativos que desembarcavam na América eram redistribuídos no tráfico regional. Devido essa multiplicidade de meandros criados pelo tráfico humano, há muitas incertezas nos estudos a respeito das origens dessas populações. ${ }^{5}$

Misturados nos portos de embarque e desembarque e também no comércio interno, não era possível que os indivíduos apartados de suas comunidades mantivessem aqui suas redes de relações sociais, religiosas ou mesmo suas identidades de origem. No amálgama entre os diferentes grupos de africanos, portugueses e ameríndios, foram criados novos códigos culturais na colônia luso-americana, diferentes dos existentes na África. Chegando à margem oeste do atlântico, esses imigrantes compulsórios recebiam identificações genéricas, prevalecendo a diferenciação entre "boçais" (africanos não falantes do português e portadores dos costumes de sua origem), "ladinos" (africanos falantes do português e adaptados aos costumes locais) e "criolos" (nascidos na colônia lusitana ou império brasileiro, cujo português era primeira língua, sendo nome também dado aos mestiços indígenas). Diferenciava-se também o "forro" (alforriado ou liberto) do "livre" (nascido do ventre de mãe livre). ${ }^{6}$

Após a proibição oficial do comércio atlântico de escravizados, em 1831, aumentaram a demanda e preço dos cativos, gerando uma progressiva concentração da população nas grandes propriedades rurais exportadoras do sudeste cafeeiro. Incompatível com a Constituição de 1824 (que declarava o direito inalienável do homem à liberdade) e com os novos interesses colonialistas ingleses, a escravidão começou a ser questionada por uma significativa fração da população, ampliando as rebeliões e tensões internas em torno dessa instituição. Ao longo do século XIX a população negra e mestiça brasileira foi se tornando majoritariamente livre ou forra. No entanto, a restrição efetiva do tráfico atlântico humano ocorreu apenas em 1850 e a abolição em 1888, quando os escravizados correspondiam 5\% da

${ }^{5}$ FLORENTINO, Manolo; VIEIRA RIBEIRO, Alexandre; DOMINGUES DA SILVA, Daniel. Aspectos comparativos do tráfico de africanos para o Brasil: séculos XVIII e XIX. Revista Afro-Ásia da Universidade Federal da Bahia, Salvador, n. 31, p. 83-126, 2004.

${ }^{6}$ SOUZA, Marina de Mello, op. cit., p.89. 
população total. Dessa forma o Brasil foi o último país do mundo ocidental a proibir a escravidão. $^{7}$

O fluxo populacional e comercial de povos entre os dois lados do Atlântico Sul teceu conexões sólidas entre África e Brasil. No entanto, durante a formação inicial da historiografia brasileira, as contribuições das culturas negras foram colocadas em segundo plano, como expomos brevemente adiante.

\section{2 - JUÍZOSÀ PORTUGUESA NA CONSTRUÇÃO DA HISTORIOGRAFIA BRASILEIRA}

O pensamento europeu expandia seus domínios sobre o globo terrestre a partir do século XVIII através da ciência, ou seja, pela sistematização do estudo da natureza e da história humana sob uma ótica hierárquica onde seus criadores europeus e tudo a que esses estejam relacionados ocupavam posição privilegiada. Esses termos desiguais foram adotados também pelos povos subjugados por esse modo de racionalização ${ }^{8}$. O desenvolvimento de ideias e a construção de conceitos teóricos na ciência brasileira participaram desse diálogo assimétrico.

As representações das memórias sobre o passado humano, construídas a partir de demandas contemporâneas de quem as manipulam, são artefatos aos quais se recorrem sempre que se faz necessário justificar ações do presente ou repensar projetos para o futuro. Durante a formação das primeiras instituições científicas brasileiras, entre o fim do século XIX e início do século XX, foi desenvolvido um complexo mito de origem para representação do Brasil como país 'mestiço' digno de inserção no ocidente civilizado, onde foram utilizadas ideias de hierarquia racial. Nessa interpretação, a herança portuguesa dominante teria se permitido o amálgama com negros e indígenas para adaptação ao novo meio e sociedade?

Uma das instituições criadas nesse contexto foi o Serviço do Patrimônio Histórico e Artístico Nacional, oficialmente fundado em 1937, durante o Estado Novo. Objetivando a criação de uma unidade nacional através de bens que fornecessem lastro a uma ancestralidade

\footnotetext{
${ }^{7}$ COSTA, Emília Viotti da. A Abolição. São Paulo: Editora da Unesp, 2010.

${ }^{8}$ PRATT, Mary. Os olhos do império: relatos de viagem e transculturação. Bauru, SP: EDUSC, 1999. p.23-75

${ }^{9}$ SCHWARCZ, Lilia Moritz. O espetáculo das raças: cientistas, instituições e questão racial no Brasil - 1870-1930. São Paulo: Companhia das Letras, 1993. p.11-22/ p.43-66.
} 
comum aos povos brasileiros e contornasse conflitos internos, intelectuais do SPHAN (entre eles Lúcio Costa e Rodrigo Melo Franco de Andrade), crentes na universalidade da cultura e arte, reafirmaram a herança portuguesa predominante na formação da sociedade brasileira. Forjaram, assim, conceitos classificadores de obras produzidas no Brasil para inseri-las nos critérios estabelecidos para a História da Arte e Arquitetura europeia. ${ }^{10}$

Os autores que inauguraram as interpretações históricas no Brasil consideraram a população negra como elemento essencial ao funcionamento das atividades cotidianas durante a escravidão, já que seus serviços prestados aos escravocratas viabilizavam a utilização das edificações, resolvendo os problemas derivados da precariedade tecnológica das construções, como o fornecimento de água, esgoto e afins. ${ }^{11}$

Parece pertinente relacionar esse esforço brasileiro de aproximação da Europa Ocidental com a difusão das doutrinas de superioridade racial e cultural europeia a partir de meados de século XIX, cuja missão civilizadora autoatribuída do europeu sobre os demais povos endossou a expansão colonial desse sobre territórios africanos e asiáticos ${ }^{12}$. Assim, as instituições e intelectuais brasileiros que buscavam criar uma identidade nacional, ao destacarem a herança portuguesa civilizada na formação do Brasil, buscavam reiterar a autonomia da jovem nação.

Assim, o fazer do negro não foi considerado elemento de destaque na cultura material brasileira. No entanto, é possível que os povos africanos e seus descendentes não tenham contribuído com a conformação dos territórios onde estiveram presentes? Vemos que essas conclusões depreciativas na historiografia sobre a participação ativa dos negros na produção material não foram tomadas após minuciosas pesquisas sobre o assunto, mas influenciadas por uma necessidade da época de alinhamento do Brasil com o "Ocidente Civilizado" europeu racialmente hierarquizado.

${ }^{10}$ CHUVA, Márcia. Fundando a nação: a representação de um Brasil barroco, moderno e civilizado. Revista Topoi. Rio de Janeiro, v.4, n.7, p.313-333, jul/dez, 2003.

${ }^{11}$ MELLO, Bruno César Euphrasio de. E o negro na arquitetura brasileira?. Arquitextos, São Paulo, ano 13, n. 145.01, Vitruvius, jun. 2012. Disponível em: https://www.vitruvius.com.br/revistas/read/arquitextos/13.145/4372. Acesso em: out.2018.

${ }^{12}$ PRATT, 1999, loc. cit.; HERNANDEZ, Leila Maria Gonçalves Leite. A África na sala de aula: visita à história contemporânea. São Paulo: Selo Negro, 2005. p.17-44. 
Base fundamental de nossa população, percebemos que os africanos foram agentes da transposição de seus rituais e conhecimentos para a constituição do Brasil, influenciando a cultura imaterial e material de nosso País. A participação ativa das culturas negras na arquitetura e conformação do território brasileiro ainda é assunto pouco estudado na historiografia, cuja ampliação do campo de estudos demanda que se extrapole sua concepção eurocêntrica de atribuição de valor, à qual ainda nos vemos apegados.

Extraídos de sociedades múltiplas, os africanos representavam parte significativa da população no Novo Mundo. O legado da África Subsaariana sobre manifestações materiais no Brasil suscita um universo de questões que precisam de grande dedicação de estudos acadêmicos para que se possam chegar a considerações consistentes a respeito de sua reverberação. Apesar das perseguições, coerções físicas e psicológicas contra esse grupo no Novo Mundo, apesar dos fatores materiais, sociais e legais que condicionavam desfavoravelmente a atuação dos negros, podemos identificar heranças africanas na recriação das tipologias, técnicas construtivas e formas de uso das construções e povoação em terras brasileiras?

Como veremos adiante, estudos históricos e geográficos recentes revelam que durante a reorganização das identidades e relações dos negros na sociedade escravista luso-americana, as condições materiais e sociais adversas não parecem terem impedido que algumas características oriundas de suas culturas de origem tenham interferido na execução das edificações para seu próprio uso, como na utilização de seus conhecimentos práticos sobre materiais e técnicas construtivas e costumes de uso das construções e entorno.

Consideramos que os diferentes povos da África Subsaariana conectados deste lado do atlântico, influenciaram e foram influenciados pela interação entre diversas culturas negras, colonos portugueses e povos nativos no Novo Mundo, colaborando ativamente na criação desta nova sociedade. Sem nenhuma pretensão de esgotar as questões possíveis, resgatamos alguns elementos relacionados à matéria nessa pesquisa, que se concentra nos quilombos encontrados na região de fronteiras entre as capitanias de Minas Gerais, São Paulo e Goiás em meados do século XVIII.

As culturas e modo de vida dos povos africanos dispersos pelo globo são temas de diferentes estudos. Para nos acercarmos de parte dessas discussões, apresentamos um panorama sobre os conceitos de diáspora africana, negritude e quilombismo. 


\section{3 - NOTAS SOBRE O CONCEITO DE DIÁSPORA AFRICANA E SOBRE O IDEAL DE QUILOMBO PARA A IDENTIDADE CULTURAL E LUTAS POLÍTICAS NO BRASIL}

O termo "diáspora" foi incorporado ao vocabulário dos estudos e prática política dos negros a partir do pensamento sionista. Associados à ideia judia de dispersão, exílio e escravidão, os discursos libertadores de movimentos negros usaram a metáfora da terra prometida como meio de restauração e retorno ao momento originário ${ }^{13}$. A genealogia do conceito de diáspora africana é nebulosa, podendo, segundo Paul Gilroy, serem destacados seus impactos nas formulações pan-africanas (a partir de meados de século XIX), no movimento da Negritude (inspirado na cultura do Harlem nos Estados Unidos e lançado em Paris em 1930) e na revista francesa Présence Africaine (publicada desde 1947). ${ }^{14}$

A experiência da diáspora é uma questão conceitual e epistemológica, mas também empírica, relacionada à identidade cultural. De acordo com Stuart Hall, em certos momentos essa identidade cultural foi entendida como unidade essencial e indivisível fixada no nascimento, constituindo a natureza dos indivíduos e de suas comunidades e, portanto, impermeável às influências superficiais e mundanas, como a alteração do local de residência. Esse teste de autenticidade, ao que chamamos tradição, foi matéria para construção de imaginários que buscavam conferir sentido às histórias e influenciar ações. No entanto, essas ideias de culturas inatas e imutáveis são mitos fundadores, que se apoiam em narrativas anacrônicas e cíclicas.

Fora do mundo das fábulas, as identidades culturais são questões históricas, não podendo ser interpretadas a partir de metáforas, já que a cultura não é uma questão de ser, mas de se tornar, estando em permanente trabalho de produção, formação e tradução de significados. Relacionada aos imaginários de rigidez e imutabilidade cultural, construída pela diferenciação radical entre certos grupos de "outros", uma concepção fechada de diáspora não é adequada para a compreensão de povos com origens diversas. ${ }^{15}$

A ideia de "África" é um conceito moderno que engloba uma grande diversidade de povos (com culturas e línguas variadas) habitando espaços com diferentes ecologias, sendo

\footnotetext{
${ }^{13}$ HALL, Stuart. Da diáspora: Identidades e mediações culturais. trad. Adelaine Resende; org. Liv Sovik. $2^{\circ}$ edição. Belo Horizonte: ed. UFMG, 2013. [original em inglês de 2003]. p.30-32.

${ }^{14}$ GILROY, Paul. O Atlântico negro. trad. Patrícia Farias. São Paulo: Ed. 34; Rio de Janeiro: Univ. Candido Mendes, Centro de Estudos Afro-Asiáticos, 2001. [original em inglês de 1993]. p.382-393.

${ }^{15}$ HALL, op. cit., p.30-32/ p.36/p.49.
} 
que o contato entre alguns grupos africanos ocorreu somente através do tráfico atlântico de escravizados, a partir do século XV. Dessa maneira, a modernidade ocidental foi inaugurada por ato de violência, nascendo pela expropriação, genocídio, escravidão e dependência colonial. Povos de diferentes continentes, obrigados a se juntar na cena do Novo Mundo, geraram culturas híbridas que não podem ser desmembradas para reconstituir elementos autênticos de origem. ${ }^{16}$

Dessa maneira, os conceitos apresentados por Mary Pratt e Stuart Hall são adequados para compreensão das sociedades constituídas na lógica colonial. Nessas "zonas de contato" se deram a copresença espacial e temporal de sujeitos anteriormente isolados por disjunturas geográficas e históricas, gerando interações que se desenrolam no interior de relações de poder radicalmente assimétricas ${ }^{17}$.

Ocorre assim o fenômeno de "transculturação", onde os grupos subordinados selecionam e reinventam suas culturas a partir dos materiais transmitidos a eles pela cultura metropolitana dominante. Vistas como impuras em termos antropológicos (devido às perdas do formato original que se fizeram necessárias à sua inserção na modernidade), as culturas sincréticas modeladas no violento turbilhão colonial criaram o que podemos chamar de estética cultural diaspórica.

Stuart Hall analisou a cultura afro-caribenha na Grã-Bretanha como exemplo de cultura híbrida gerada na diáspora moderna, cuja produção relê o significado das heranças africanas espalhadas pelo mundo, não como ponto de referência antropológica fixo, mas como matéria-prima para histórias alternativas, com sobrevivências sobrepujadas pelo processo de tradução cultural. Não se trataria de transportar significados (que não vêm prontos), mas de uma reconstrução e remodelação do significado original. A tradução e reencontro com tradições, nesse caso, tem a ideia de África como um significante apropriado e transformado nos diferentes partes do globo. ${ }^{18}$

Uma nova discussão sobre conceito de diáspora teria surgido como resposta aos ganhos advindos do movimento Black Power durante a guerra fria, propondo a reconfiguração da relação entre África e população descendente de africanos do hemisfério ocidental. A argumentação foi sustentada por ativistas com ideais de libertação nacional, apontando as

\footnotetext{
${ }^{16}$ HALL, op. cit., p.33-34.

${ }^{17}$ PRATT, 1992 , loc. cit.

${ }^{18}$ HALL, op. cit., p.34-38/ p.44-45.
} 
limitações dos meios vigentes para conceituar as culturas, identidades e organizações políticas. Esse novo raciocínio não recupera tradições raciais hermeticamente lacradas e culturalmente absolutas que invocam o pré-moderno e o antimoderno, mas reconhecem o valor legitimo da mutação, hibridez e mistura cultural e social. ${ }^{19}$

Essa renovada concepção de diáspora possibilita realizar leituras alternativas das trajetórias de povos modernos e suas culturas, que se desenvolveram no interior da civilização ocidental, mas são obrigados a se sentir fora dela. Observadas por epistemes pretensamente internacionalistas, que estruturam suas visões de sociedade a partir de eixos dominantes de afiliações políticas, militares e econômicas, as sociedades pós-coloniais seriam zonas de silêncios. $^{20}$

Segundo Gilroy, a ideia de diáspora encoraja populações dispersas a sincronizar elementos de suas vidas culturais e sociais para além das fronteiras dos Estados nacionais, não buscando simples sobrevivências africanas (que nunca serão intactas ou completas), mas enxergando as relações sociais na lógica de combinações e sincretismos, como processos que amalgamam elementos imprevisíveis e não planejados vindos das fontes mais diversas. Essa narrativa emergente propõe relacionar, combinar e unificar experiências modernas das comunidades e interesses dos negros de várias partes do mundo.

Assim, o conceito de diáspora se tornou menos um argumento a respeito da identidade, hibridez, globalização de culturas, confrontadas com os mecanismos disciplinares dos Estados, e mais uma disputa de códigos que não observam raças, mas formas geopolíticas e geoculturais de vida resultantes da interação entre grupos em diferentes espaços. Fundandose nesse pensamento é possível elaborar novos reguladores para a escrita da História das culturas negras no ocidente. ${ }^{21}$

No Brasil, um epicentro da escravidão moderna, o ideal de pureza teria sentido mais nebuloso em relação à política cultural, ideias de raça e identidade nacional. Aqui, as lutas políticas buscavam forçar o reconhecimento do racismo como aspecto estruturante da sociedade brasileira $^{22}$. A releitura das heranças africanas e a proposição de conexões entre os povos negros dispersos pelo mundo foram exploradas por integrantes do movimento negro

\footnotetext{
${ }^{19}$ GILROY, op. cit., p. 17 e 415.

${ }^{20}$ HALL, op. cit., p.52-53.

${ }^{21}$ GILROY, op. cit., p.11/ p.20-25.

${ }^{22}$ GILROY, op. cit., p.10.
} 
brasileiro. Entre eles, temos os trabalhos do político e artista Abdias do Nascimento (19142011), iniciados na década de 1970.

Na publicação de seu discurso para VI congresso pan-africano (realizado em junho de 1974 na Tanzânia) Abdias do Nascimento defendeu que a luta dos povos negros de todo o mundo requeria o conhecimento e compreensão recíproca, porém a comunicação entre os membros da "família africana fora do continente" era dificultada pela diversidade de línguas faladas. Os negros em diferentes países tinham em comum as experiências de discriminação e humilhação social, tendo sua cor transformada em marca e causa de sua pobreza, opressão e afastamento do poder, cuja minoria branca monopolizava. Nas análises dos problemas enfrentados pela população, era ignorada a influência de fatores raciais de discriminação e desigualdade, reduzindo os argumentos a critérios socioeconômicos.

Abdias do Nascimento apontou a necessidade de combate ao tipo peculiar de racismo de criação luso-brasileira, "sutil, difuso, evasivo, camuflado, assimétrico, mascarado, porém tão implacável e persistente que está liquidando definitivamente os homens e mulheres da raça negra que conseguiram sobreviver ao massacre praticado no Brasil". Esse racismo teria sido disfarçado pela utopia da "Democracia racial", que confunde e frustra o povo afrobrasileiro, barrando sua autoafirmação de identidade com integridade e orgulho. Segundo o autor, era necessário deixar de silenciar a voz e não mais perdoar ou esquecer o "holocausto de milhões sem conta - cem, duzentos, trezentos milhões? - de africanos (homens, mulheres, crianças) friamente assassinados, torturados, estuprados e raptados por criminosos europeus durante a escravidão e depois dela", assim como evitar o desaparecimento das massas negras no Brasil, por miscigenação compulsória, assimilação ou morte.

A proposta desse movimento político era reatar os liames com a África, recriar os vínculos de solidariedade com os irmãos africanos do continente e da diáspora, para firmar o lugar das nações negras no globo e acessar o poder em seus países.

Abdias entende o quilombo dos Palmares como exemplo de implantação de um "comunalismo tradicional africano", que seria um tipo de socialismo de modelo africano anterior às formulações europeias similares, onde não havia exploradores e explorados. Esse modelo despertaria a consciência afro-brasileira e proclamava o direito desses ao poder. ${ }^{23}$

${ }^{23}$ NASCIMENTO, Abdias do. O Quilombismo: documentos de uma militância pan-africanista. Rio de Janeiro: ed. Vozes, 1980. p.11-30. 
Outros pensadores brasileiros também se apoiaram no imaginário sobre quilombos famosos na história como símbolos para lutas travadas ao longo do século XX. Os trabalhos do etnólogo Edison Carneiro (1912-1972) e do sociólogo Clóvis Moura (1925-2003), figuram entre os precursores nos estudos dos quilombos.

Para Edison Carneiro, a fuga e ajuntamento dos escravizados negros nos quilombos era uma forma de restaurarem antigos estilos de vida e organizações sociais de acordo seus valores africanos. Já para Clóvis Moura, os quilombos constituiriam uma sociedade alternativa baseada no trabalho livre, onde havia associação de diferentes grupos em oposição ao sistema dominante (negros fugidos da escravidão, índios destribalizados, foragidos da justiça, entre outros), constituindo uma democracia racial em meio à sociedade escravista, onde teriam sido reelaborados valores sociais e culturais africanos, acrescidos pela experiência empírica adquirida em cativeiro na América. ${ }^{24}$

As visões de Edison Carneiro, Clóvis Moura e Abdias do Nascimento eram abrangentes e vinculadas a esquemas interpretativos preestabelecidos e politicamente orientados. Por isso, suas idéias esboçadas sobre os quilombos (onde imperaria a fraternidade entre grupos oprimidos, a liberdade e extinção local da escravidão ou, de isolamento com sociedade e reedificação de comunidade autenticamente africana), não são perfeitamente adequadas para compreender a diversidade e complexidade das organizações quilombolas constituídas ao longo dos séculos em diferentes regiões.

Apesar das análises históricas de Edson Carneiro, Clóvis Moura e Abdias do Nascimento estarem defasadas frente aos debates atuais, os pronunciamentos desses intelectuais de vanguarda são fundamentais para nosso entendimento das questões sobre as quais foram construídos os pensamentos a respeito dos quilombos, sendo referência para estudos posteriores. A potencialidade do conceito de quilombo foi explorada por membros do movimento negro como instrumento de construção de identidade cultural, manifestação de resistência e afirmação política, que nos convidam à revisão de conceitos históricos.

Como apontado pela historiadora Beatriz Nascimento (1942-1995), a intenção era reverter a visão ocidental da África como um continente isolado e sem história até a chegada

${ }^{24}$ CARNEIRO, Edison. Singularidades dos Quilombos. In: MOURA. Os quilombos na dinâmica social do Brasil, Alagoas: EDUFAL, 2001. p.11-18.; MOURA, Clóvis. A quilombagem com expressão de protesto radical. In: MOURA. Os quilombos na dinâmica social do Brasil. Alagoas: EDUFAL, 2001. p.103-115. 
dos europeus. A revelação do passado africano e do lugar de seus povos na história dos países em que foram alocados depois da travessia do atlântico, era essencial para a construção da identidade dos afrodescendentes. Assim, a ideia de quilombo representava um marco da capacidade de resistência e organização do negro na História do Brasil.

O imaginário sobre as comunidades de fugitivos durante o período escravista começou a ter significado como meio ideológico contra a opressão no fim do século XIX, alimentando o sonho de liberdade de escravizados. De acordo com Beatriz Nascimento, já nesse momento o "quilombo" começa a ser redefinido com símbolo de resistência. No início do século XX, com o desejo de libertação da consciência nacional, o quilombo foi caracterizado em publicações de Nina Rodrigues, Ernesto Enne, Edson Carneiro, Arthur Ramos e Guerreiro Ramos.

A busca por aspectos positivos que pudessem reforçar a identidade histórica brasileira negra perdurou. Nas manifestações artísticas (como no samba, teatro e outros) o quilombo é ícone da resistência popular às formas de opressão e da esperança de união e igualdade social.

Na década de 1970 (momento em que o Estado sufocava o pensamento e liberdade de reunião) a figura de Zumbi ganhou força como símbolo heróico do passado. Em substituição ao "13 de maio" assombrado pela memória da escravidão, foi proposto o destaque do dia 20 de novembro no calendário de celebrações nacionais para fundar sobre a recordação da queda do quilombo dos Palmares e assassinato de Zumbi a memória da capacidade de resistência dos antepassados, criando uma identificação cultural mais positiva. ${ }^{25}$

Para esses ativistas, os quilombos são um conceito, um símbolo de resistência e identidade dos negros, de valorização de suas heranças, de suas afirmações como importantes personagens na constituição nacional, interligados ao mundo moderno através de suas origens e vivências em comum com diferentes grupos em diáspora, que buscam unir suas forças nas lutas pela conquista da cidadania plena.

Conhecer o passado de lutas dos mais diferentes grupos, entre elas as dos quilombolas, interessa a todos aqueles que compõem nossa sociedade. Esses temas dizem respeito mesmo

25 NASCIMENTO, Beatriz. O conceito de quilombo e a resistência cultural negra. Revista Afrodiáspora, Rio de Janeiro, ano 3, v. 6 e 7, p-41-49, abr./dez., 1985. Disponível em: <http://ipeafro.org.br/acervo-digital/leituras/publicacoes-do-ipeafro/afrodiaspora-vol-6-e-7/> . Acessado em: dez.2018. 
àqueles que por ventura não se identifiquem como afrodescendentes, pois são relevantes à História do Brasil. Somente no momento em que formos capazes de equilibrar a balança da igualdade de direitos e representatividade, poderemos obter um Estado democrático efetivo.

É importante salientar que a imagem dos quilombos elaborados pelas organizações político-culturais são monumentos imateriais e atemporais. Eles não devem ser confundidos com as comunidades de fugitivos do passado que estudos históricos e geográficos recentes buscam compreender a partir de seus poucos vestígios documentais e arqueológicos.

Com olhar diferente desses movimentos político-culturais, esta pesquisa analisa os quilombos do Campo Grande no século XVIII como objetos históricos (circunscritos aos seus tempos e indissociáveis dos espaços geográficos onde estavam implantados), procurando traçar esboços sobre suas conformações espaciais através dos poucos registros que nos restaram sobre esses povoados.

Os dados trazidos pelas fontes, por vezes, podem frustrar expectativas idealizadas sobre o que foram tais comunidades. Devido à escassez de documentos, nossas insatisfações normalmente derivam das poucas respostas que conseguimos ter, diante de nossas muitas perguntas. Resta-nos, portanto, extrair questões válidas desses documentos para construir o máximo de conjecturas sobre as realidades possíveis desses quilombos que estão séculos distantes de nós. 


\section{4 - INTRODUÇÃO AOS ESTUDOS SOBRE QUILOMBOS}

Para nos acercar das questões que podem ser investigadas ao observarmos os vestígios das comunidades que constituem o objeto central da pesquisa, revemos adiante a interpretação de alguns dos autores sobre os quilombos no Brasil.

\subsection{1 - Primeiros trabalhos sobre quilombos na historiografia}

Como visto anteriormente, um dos primeiros autores no Brasil a tratar do tema foi Edison Carneiro. Durante conferência em Dakar em $1953^{26}$, o etnólogo apresentou sua análise sobre os quilombos brasileiros, considerando a fuga e ajuntamento dos africanos escravizados nos matos como o principal método utilizado para escapar das agruras do cativeiro e como forma de rejeitarem a sociedade oficial (que oprimia sua língua, religião e cultura). No isolamento dos quilombos, os fugitivos podiam restaurar antigos estilos de vida e organizações sociais de acordo com suas tradições africanas.

Já na visão de Clóvis Moura ${ }^{27}$ (sociólogo integrante do movimento negro e de partidos comunistas brasileiros desde a década de 1940), ao se unir à uma organização quilombola, o escravizado em fuga passava de rebelde solitário para um nível superior de consciência de negação coletiva da escravidão. O quilombo formaria uma sociedade paralela ao sistema colonial escravista, contra o qual instituíra uma ruptura social e econômica radical. Essa sociedade alternativa seria baseada no trabalho livre, com ausência de hierarquias que não fossem as necessárias para defesa de suas liberdades. Local de concentração de diferentes grupos em oposição ao sistema dominante (negros fugidos da escravidão, índios destribalizados, foragidos da justiça, entre outros), os quilombos constituiriam uma democracia racial em meio à sociedade escravista, da qual não estavam isolados, mas manteriam interações, fossem pacíficas ou conflitantes.

Segundo a leitura de Moura, a formação de quilombos eram formas de defesa contra a violência escravista. Neles seriam reelaborados valores sociais e culturais africanos, acrescidos pela experiência empírica adquirida em cativeiro na América. Alguns quilombos tiveram líderes famosos, como Zumbi, Ambrósio, Dom Cosme. Para o autor, apesar dos núcleos quilombolas terem sido individualmente destruídos, eles permaneceram ressurgindo

\footnotetext{
${ }^{26}$ CARNEIRO, 2001, loc. cit.

${ }^{27}$ MOURA, 2001, loc. cit.
} 
em diferentes espaços geográficos e históricos, instituindo um contínuo desgaste ao sistema de produção escravista.

Como já dito, as obras de Edison Carneiro e de Clóvis Moura destacaram a importância dos quilombos como símbolos das lutas pela igualdade de direitos. No entanto, interpretações gerais e idealizadas são inadequadas para análises históricas detalhadas. Estudos de caso sobre quilombos específicos ${ }^{28}$ têm revelado situações geográficas, alianças econômicas e sociais complexas e heterogêneas.

\subsection{2 - 0 que são Quilombos e Mocambos}

As palavras "Mocambo" e "Quilombo" podem ser consideradas sinônimos 29 . O termo "mocambo" era inicialmente usado para se referir aos redutos de negros em fuga do cativeiro, enquanto o termo "quilombo" foi difundido somente a partir de 1740. Houve variações na definição do Estado luso-americano sobre o número mínimo de habitantes ou necessidade da existência de pilões para fabricação de farinhas para que essas aglomerações fossem consideradas quilombos. ${ }^{30}$

Visto que esta pesquisa se restringe ao estudo das povoações quilombolas implantadas nas proximidades de regiões auríferas no século XVIII e às relações dessas com os demais elementos dessa sociedade, não tratamos das comunidades atualmente existentes que também são chamadas de quilombos.

${ }^{28}$ Os casos do quilombo do Oitizeiro (implantado dentro de fazendas na Bahia em 1806), da conspiração de escravos na Bahia em 1814 e do quilombo do Piolho em 1770 e 1795 no Mato Grosso, mostram a diversidade das associações e disputas entre diferentes grupos sociais nas comunidades quilombolas e sociedade escravista. Ver: REIS, 1996, p.332-372; SCHWARTZ, 1996, p.373-406; GOMES, 2005, p.358-364.

${ }^{29}$ Ver: MOCAMBO; QUILOMBO. In: MOURA, Clóvis. Dicionário da Escravidão Negra no Brasil. São Paulo: Editora da Universidade de São Paulo, 2004. 277p./ 335-339p.; GOMES, Flávio. Quilombos/ Remanescentes de Quilombos. In: SCHWARCZ; GOMES (org.). Dicionário da escravidão e liberdade: 50 textos críticos. São Paulo: Companhia das Letras, 2018. p.367-373.

${ }^{30}$ GUIMARÃES, Carlos Magno. Quilombos, classes, estado e cotidiano: Minas Gerais, século XVIII. 1999 f. Tese (Doutorado em História) - Faculdade de Filosofia, Letras e Ciências Humanas da Universidade de São Paulo, São Paulo. p.191-196. 


\subsection{3 - A heterogeneidade dos quilombos}

Segundo o geógrafo Manuel Correia de Andrade (1922-2007), para compreender as particularidades de cada um dos quilombos é essencial observar as características físicas (relevo, clima, solos, hidrografia e vegetação) e humanas (população, tipo de povoamento, integração entre grupos, distribuição da população no espaço) do território de implantação dos povoados. Fossem pequenas aglomerações ou comunidades com centenas de fugitivos, os povoados quilombolas estiveram presentes em todas as regiões onde houve escravidão. Os quilombos do século XVI e início do XVII (quando a dominação portuguesa era territorialmente restrita) eram muito diferentes daqueles dos séculos XVIII e XIX (momento quando houve a apropriação do interior do território pelos luso-americanos através da penetração de criadores de gado, caçadores de indígenas e minérios).

As regiões montanhosas com florestas exerciam especial atração à fundação de núcleos quilombolas, devido à facilitação da defesa, oferta de alimentos como frutos e animais para caça, disponibilidade de espaço para cultivo, fornecimento de madeira para construções e armas. As construções seriam feitas com folhas e galhos de árvores, sendo executadas com rapidez. A proximidade de cursos d'água era necessária para abastecimento doméstico, sendo os riachos e rios não navegáveis os preferidos, por dificultar acesso do inimigo através de embarcações.

Os pontos altos do relevo funcionavam como mirantes para observação de invasores à distância, assim podendo afastar os moradores e o gado do local antes da chegada de tropas repressoras. Favorecidos pelo conhecimento do terreno, para o combate contra os adversários os quilombolas usavam sistema de guerrilha, atacando em pequenos grupos e empregando emboscadas no caminho para que não chegassem às cercas do quilombo. ${ }^{31}$

\subsection{4 - Relações entre quilombolas e outros grupos da sociedade}

Sobre as relações entre quilombos e sociedade dominante, Manuel Correia de Andrade ressalta as trocas comerciais ou furtos para obtenção de sal, pólvora e armas. Alguns quilombolas poderiam ter acesso regular às cidades, preferindo o período da noite para fazêlo, quando a parca iluminação dificultaria seu reconhecimento por inimigos. Os quilombos

31 ANDRADE, Manuel Correia de. Geografia do quilombo. In: MOURA, Clóvis (org.). Os quilombos na dinâmica social do Brasil. Alagoas: EDUFAL, 2001. p.75-86. 
seriam internamente hierarquizados, possivelmente com organização tributária de estruturas africanas. Por vezes os quilombolas se aliavam aos ameríndios contra inimigos comuns. Os africanos eram batizados antes da travessia do atlântico e recebiam catequização no cativeiro, o que podia resultar no sincretismo religioso e uso corrente da língua portuguesa dentro dos mocambos. Dessa forma, os quilombos seriam um ponto de encontro entre culturas. ${ }^{32}$

Carlos Magno Guimarães fala que as relações dos calhambolas ${ }^{33}$ com a sociedade escravista mineira podiam consistir no comércio clandestino com contrabandistas, taverneiros, negras de tabuleiro e fazendeiros; nos ataques contra viajantes, tropeiros, fazendas e arredores urbanos; em relações afetivas entre livres, libertos e quilombolas, que frequentavam as vilas e senzalas, onde trocavam informações. Outro tipo de ligação com a sociedade, negativa, era a repressão por meio de legislação e tropas de ataque. ${ }^{34}$

As interações entre quilombolas e indígenas eram ambíguas. Como analisa Mary Karasch, ainda que ambos se associassem algumas vezes, em muitos eventos eles se encontravam de lados opostos. Os indígenas guerreavam contra quilombolas por agenciamento próprio, devido à disputa por terras ou para preservar mulheres do sequestro pelos calhambolas. Outras vezes, eram recrutados pelo governo para servirem como homens do mato na repressão aos quilombos. ${ }^{35}$

Os relacionamentos entre grupos da sociedade com diferentes estamentos jurídicos e sociais eram complexos e instáveis. Por vezes, a convergência de interesses uniu quilombolas com escravizados, com pessoas livres pobres, com ameríndios, com senhores de terras e com outros integrantes da sociedade, agregando suas forças contra inimigos em comum. Foram os casos da guerra da Balaiada (ocorrida nas províncias do Maranhão, Piauí e parte do Ceará entre 1838 e 1841) e da guerra dos Cabanos (cujas batalhas aconteceram na fronteira entre Alagoas e Pernambuco entre 1832 e 1835), que figuraram entre as maiores revoltas populares

\footnotetext{
${ }^{32}$ ANDRADE, 2001, loc. cit.

${ }^{33}$ Segundo Clóvis Moura o termo "calhambola" pode ser usado com sinônimo de quilombola, sendo comumente usado nos documentos oficiais da época da escravidão para identificar o negro fugido, fosse ameríndio ou afrodescendente. Ver: CALHAMBOLA. In: MOURA (org.), 2004, p.79.

${ }^{34}$ GUIMARÃES, Carlos Magno. Mineração, quilombos e Palmares: Minas Gerais do século XVIII. In: REIS; GOMES (org.). Liberdade por um fio: história dos quilombos no Brasil. São Paulo: Companhia das Letras, 1996. p.139-163.

${ }^{35} \mathrm{KARASCH}$, Mary. Os quilombos do ouro na capitania de Goiás. In: REIS; GOMES (org.), op. cit., p.240-262.
} 
de nossa história. No entanto, tais alianças eram extraordinárias e circunstanciais. Com o declínio desses movimentos, as situações divergentes entre os grupos eram usadas para derrubá-los. ${ }^{36}$

Certos aspectos dos quilombos que figuram nas guerras dos Cabanos $^{37}$ e da Balaiada ${ }^{38}$ - como o uso das matas como local de preservação e de batalha contra o sistema dominante, a possível associação de diferentes grupos dentro nos quilombos (pretos, ameríndios e brancos pobres), a mistura de elementos católicos com os de outras religiões e culturas dentro das comunidades - surgiram também nos quilombos do Campo Grande do século XVIII estudados nesta pesquisa.

\subsection{5 - Composição social das tropas contra quilombos}

A descoberta de ouro no interior do continente coincidiu com a destruição dos Palmares, maior e mais duradouro dos quilombos de nossa história, que permaneceu nas matas nos arredores de Pernambuco por quase todo o século XVII. A possibilidade da repetição do fenômeno era motivo de medo por parte das autoridades do Estado lusitano. Por esse motivo, a administração portuguesa teria criado um aparelho repressor que pudesse conter a atuação dos quilombolas dentro de limites suportáveis para a ordem escravista. Parte

${ }^{36}$ ANDRADE, Manuel C. de. A guerra dos Cabanos. Rio de Janeiro: Conquista, 1965. p.197-213. CARVALHO, Marcus J. M. de. Um exército de índios, quilombolas e senhores de engenho contra os 'jacubinos': a Cabanada, 1832-1835. In: DANTAS, Monica Duarte (org.). Revoltas, motins, revoluções: homens livres pobres e libertos no Brasil do século XIX. São Paulo: Alameda, 2011. p.167-200.

ASSUNÇÃO, Matthias Röhring. "Sustentar a Constituição e a Santa Religião Católica, amar a Pátria e o Imperador". Liberalismo popular e o ideário da Balaiada no Maranhão. In: DANTAS (org.), op.cit., p.295-327.

${ }^{37}$ Ao fim da guerra dos Cabanos, cerca de 50 "negros aquilombados" que lutaram contra o governo estabelecido se exilaram no vale do Rio Jacuípe (mesma região onde se encontravam os quilombos dos Palmares no século XVII), onde permaneceram por décadas. Segundo a descrição do frei Messina (que os visitou em 1842, chegando ao local após dois dias de caminhada em mata fechada) naquela povoação vivia um povo seminu com hábitos indígenas de casamento e fervorosa fé católica. Ver: CARVALHO, 2011, loc.cit.

${ }^{38}$ Líder de lutas na guerra da Balaiada (ocorrida no nordeste no início do século XIX) e do quilombo da Lagoa Amarela (que contava com escola para as crianças), Dom Cosme vestia adornos de estilo africano, usava feitiçaria para impressionar seu séquito e se identificava com a Irmandade do Rosário, intitulava-se imperador, falava em república e defendia a abolição generalizada com indenização para os senhores. Ele lutou pela liberdade dos de sua nação e forçou proprietários a firmar carta de alforria para aqueles que estavam sob seus cuidados. Ver: ASSUNÇÃO, 2011, loc.cit. 
dessa institucionalização se deu através da formação de tropas especializadas no combate aos quilombos, que tinham entre seus integrantes ex-escravizados africanos, indígenas e descendentes. $^{39}$

O recrutamento de brancos pobres, negros libertos, indígenas e condenados pela justiça para compor as tropas de milícias e ordenanças é um dos temas trabalhados por Laura de Mello e Souza ${ }^{40}$. A autora entende que durante o ciclo do ouro essa camada intermediária (situada entre os escravizados e os grandes proprietários) era essencial no trabalho em obras públicas, povoação de locais remotos, formação de polícias privadas e combate em áreas de fronteiras. Assim, a ordem portuguesa teria encontrado um meio de "dar utilidade a esses vadios" em seu processo de conquista colonial. Boa parte dos integrantes das tropas contra quilombos eram advindos desse setor da sociedade, através do trabalho compulsório.

Os principais documentos que dispomos para esta pesquisa sobre quilombos do século XVIII foram produzidos por essas tropas. Uma vez que, com a aproximação das expedições, os calhambolas geralmente fugiam, os cotidianos dos quilombos não aparecem nos documentos.

\subsection{6 - Quilombos nos sertões das minas no século XVIII}

Os quilombos nos sertões das minas em meados do século XVIII, que estamos investigando através de seus vestígios documentais, tiveram certos aspectos analisados por pesquisadores que nos são contemporâneos.

O historiador Carlos Magno Guimarães identificou 160 quilombos nos relatos oficiais de Minas Gerais entre anos 1710 e 1798. Para o autor, os quilombos seriam uma das formas de manifestação do conflito geral entre classes. As principais atividades de subsistência dessas comunidades seriam a caça, coleta, agricultura, criação de animais, mineração, assalto a viajantes e fazendas. Constituídos majoritariamente por escravizados fugidos, cada mocambo teve sua época de existência, região e mecanismo de sobrevivência próprio, ou seja, uma

39 GUIMARÃES, 1996, loc. cit.; GUIMARÃES, Carlos Magno. Quilombos, classes, estado e cotidiano: Minas Gerais, século XVIII. 1999 f. Tese (Doutorado em História) - Faculdade de Filosofia, Letras e Ciências Humanas da Universidade de São Paulo, São Paulo. p.8.

${ }^{40}$ SOUZA, Laura de Mello e. Desclassificados do ouro: a pobreza mineira no século XVIII. Rio de Janeiro: Ed. Graal. $4^{\circ}$ edição, 2004. p.77-130 
configuração histórico-cultural específica. Nas áreas com ouro e diamantes, dedicavam-se à mineração clandestina e venda do material extraído para obtenção de armas, pólvora, alimentos. Já no sertão da capitania, onde não havia esses minerais, sobreviviam da agricultura, pesca e afins. $^{41}$

Estudando quilombos em diferentes épocas e regiões no Brasil, o historiador Flávio Gomes dedicou uma parte de seu livro aos quilombos registrados pela expedição comandada por Ignacio Correya Pamplona em 1769. Essa campanha foi enviada para desbravar novas terras, descobrir áreas para mineração, destruir mocambos, levar justiça às populações longínquas e promover a fé católica. Como veremos no capítulo 2, os relatórios da expedição são compostos por documentos escritos e gráficos, contendo desenhos de implantações de seis quilombos.

Gomes conjectura sobre possíveis formas de entender as hierarquias políticas e religiosas desses quilombos a partir das construções identificadas nesses desenhos (casas do rei, do conselho, de audiência e de ferreiro). Provedores de armas para guerra e ferramentas para agricultura e, como contam as tradições, fundadores de reinos na região do rio Congo na África Central, os ferreiros eram vistos como governantes generosos, habilidosos e conciliadores, sendo atribuído poder espiritual a eles.

Outro ponto enfatizado por Gomes é o sistema de defesa para contenção de ataques, como saídas com estrepes (pontaletes de madeira fincados ao chão), entradas com buracos disfarçados, trincheiras e fossos. Um dos principais meios de proteção dos quilombos contra a sociedade escravista seria o uso das florestas não colonizadas pelos agentes portugueses como local de ocultamento e batalha. A constituição dos núcleos de quilombolas nas matas permitia a invisibilidade de seus moradores em locais, por vezes, próximos de estradas ou vilas com as quais os quilombos se relacionavam através de trocas comerciais, relações sociais, saques e sequestros. $^{42}$

\footnotetext{
${ }^{41}$ GUIMAR ÃES, 1996, loc. cit.

${ }^{42}$ GOMES, Flávio dos Santos. A hidra e os pântanos: mocambos, quilombos e comunidades de fugitivos no Brasil (séculos XVII-XIX). São Paulo: Ed. UNESP: Ed. Polis, 2005. p.358-395.
} 


\subsection{7 - Considerações para os estudos dos quilombos setecentistas do Campo Grande}

Tendo em mente o panorama extraído de diferentes autores sobre quilombos em épocas e regiões distintas, podemos conceber um espectro de questões a serem observadas nos quilombos estudados como o reconhecimento dos aspectos geográficos dos sítios escolhidos para os povoados quilombolas (relevo, presença de matas e cursos d'água para abastecimento ou transporte, proximidade ou afastamento de vias de acesso e núcleos urbanos), as possíveis relações entre quilombolas e outros grupos da sociedade, os interesses dos agentes portugueses sobre os sertões do Campo Grande, a apropriação dos territórios quilombolas por súditos da coroa portuguesa e a substituição da população nessas áreas.

Esta pesquisa se concentra nos quilombos encontrados na região de fronteiras entre as capitanias de Minas Gerais, São Paulo e Goiás em meados do século XVIII, quando essas áreas constituíam parte subalterna da estrutura colonial portuguesa de regime absolutista.

Como veremos em seguida, os espaços ocupados pelos povoados quilombolas estudados ficavam nas margens das áreas dominadas pela coroa portuguesa até que - com a decadência da mineração aurífera em meados do século XVIII (gerando a sede de encontrar novas minas de ouro) e o crescente medo dos "inimigos internos" (africanos, índios ou brancos pobres, todos eles potenciais rebeldes) - a sociedade luso-americana percebeu a utilidade na abertura de novas frentes de exploração do território americano nos "sertões" 43 vizinhos.

\footnotetext{
${ }^{43}$ A noção relativa do conceito de "sertão" é exposta em: FONSECA, Cláudia Damasceno. Arraiais e vilas d'el rei: espaço e poder nas Minas setecentistas. Tradução de Maria Juliana G. Teixeira. Belo Horizonte: Ed. UFMG, 2011. p.51-57.
} 


\section{5 - EXPANSÃO DO IMPÉRIO LUSITANO NOS SERTÕES DAS MINAS SETECENTISTAS}

A expansão colonial portuguesa sobre o continente americano durante o século XVIII foi marcada pelo interesse na extração de minerais preciosos e pela disputa entre as coroas ibéricas pelo domínio de territórios.

Com o acordo de Paz de Utrecht de 1713, que invalidou o tratado de Tordesilhas, o reconhecimento da soberania sobre as terras dependia de sua ocupação efetiva. Assim, foram adotadas diferentes estratégias para ampliação e defesa do patrimônio ultramarino da coroa Bragança $^{44}$. Com o Tratado de Madri e a ascensão do primeiro ministro marquês de Pombal na década de 1750, o povoamento das zonas de fronteiras com súditos da coroa portuguesa (mesmo que fossem com indígenas aldeados, mestiços ou ilhéus dos açores) passou a ser uma das prioridades da administração metropolitana ${ }^{45}$.

Na capitania de Minas Gerais, o estabelecimento de povoados luso-americanos e a busca de jazidas minerais estiveram associados. Em meados do século XVIII, com a decadência das minas auríferas, ocorreu o crescimento do interesse por terras cujos relevos e solos fossem apropriados para a agricultura e criação de gado. A exploração de regiões até então desconhecidas pelo Estado português, dominando novos espaços através da implantação de sua estrutura civil e eclesiástica sobre locais que, geralmente, já eram ocupados por grupos de outras culturas e estruturas sociopolíticas, como "índios bravos" ou "negros aquilombados", resultava no confronto entre esses povos rivais. ${ }^{46}$

A partir da década de 1740 o governo de Minas Gerais organizou diversas expedições militares que tinham o propósito de avançar com os limites de suas fronteiras de povoamento ao mesmo tempo em que combatiam os habitantes desses locais, vistos como inimigos da coroa lusitana. Conforme prática do Antigo Regime, os súditos que empregavam seus recursos materiais e esforços pessoais no massacre dos adversários religiosos e culturais de

${ }^{44}$ KANTOR, Íris. Cartografia e diplomacia: usos geopolíticos da informação toponímica (17501850). Anais do Museu Paulista, São Paulo, v.17, n.2, p.39-.61, jul.-dez. 2009.

${ }^{45}$ SOUZA, Laura de Mello e. Norma e conflito: aspectos da História de Minas no século XVIII. Belo Horizonte: Ed. UFMG, 1999. p.111-137.

${ }^{46}$ GUIMARÃES, 1999, p.104-171; MORAES, Fernanda B. de. De arraiais, vilas e caminhos: a rede urbana das Minas coloniais. In: RESENDE; VILLALTA (org.). As Minas Setecentistas, vol.1. Belo Horizonte: Autêntica; Companhia do Tempo, 2007. p.55-85. 
sua majestade podiam ser recompensados com cargos administrativos, títulos honoríficos e concessão de sesmarias.

Assim, as terras férteis dos "sertões" próximos das escarpas mineradoras foram palco de guerra entre os quilombolas, que ali estavam estabelecidos, e os luso-americanos, que desejavam obter novas terras e proteger suas propriedades nos arredores das ameaças de ataques por "negros fugidos". 47

Integrantes de diferentes expedições bélicas confeccionaram relatos escritos e mapas para apresentarem os resultados das campanhas para as autoridades do Estado português. Produzidos nesse contexto, os três mapas selecionados como fontes primárias para a pesquisa tratam da zona entre os rios Grande, São Francisco e Paranaíba. Tais espaços eram chamados pelo nome genérico de "Campo Grande", tendo limites imprecisos, uma vez que eram pouco conhecidos pelos luso-americanos em meados do século XVIII.

O conteúdo desse tipo de documento interessava ao Estado colonial português como instrumento de conhecimento desses espaços e como meio de reivindicação do direito de domínio dos mesmos frente à civilização ocidental. A riqueza de detalhes nos registros dos quilombos da região faz com que esses manuscritos sejam extremamente valiosos aos estudos históricos contemporâneos.

Tendo em vista esse cenário, adiante nos detemos na análise de mapas e relatórios referentes a distintas campanhas que exploraram o Campo Grande entre as décadas de 1740 e 1780. A partir dos dados apresentados nos documentos, buscaremos entender algumas características dos quilombos registrados, procurando também reconhecer os interesses e as estratégias de conquistas territoriais dos agentes da coroa portuguesa sobre aqueles espaços.

\footnotetext{
47 BARBOSA, Waldemar de Almeida. A decadência das Minas e a fuga da mineração. Belo Horizonte: Imprensa da Universidade Federal de Minas Gerais, 1971. p.13-63; SOUZA, 1999, loc. cit.; FONSECA, op. cit., p.118-123.
} 


\section{Capítulo 2 - MAPAS E RELATÓRIOS DE EXPEDIÇÕES AO CAMPO GRANDE - ANÁLISE DAS FONTES PRIMÁRIAS}

De modo geral, a preservação dos quilombos estava condicionada à sua inacessibilidade pela sociedade escravista. Paradoxalmente, nossos principais meios contemporâneos de estudo dessas comunidades são os registros feitos pelas tropas que os destruíram. Executados por grupos inimigos apartados do cotidiano dos quilombolas, esses documentos militares são peças fundamentais desta pesquisa. Tais fontes primárias foram usadas por nosso estudo sob um olhar divergente ao de suas produções, para, a partir delas, esboçar um panorama do que possam ter sido alguns desses quilombos e compreender como se deram as disputas pelo domínio dos territórios.

Os três mapas manuscritos analisados e demais documentos escritos tratam de um assunto, região e período em comum: a conquista pelo Estado português de territórios povoados por quilombolas na região do Campo Grande no século XVIII. A baliza temporal da pesquisa é dada pelos episódios estudados. Os documentos aqui examinados foram produzidos entre as décadas de 1760 e 1780, mas, como veremos, seus conteúdos abordam também eventos ocorridos ao longo de todo aquele século.

A partir desses documentos de textos e imagens, procuramos entender as características arquitetônicas e espaciais daqueles povoados quilombolas implantados nas franjas das minas auríferas setecentistas e as possíveis relações entre eles. Buscamos também reconhecer como se deu o confronto entre quilombolas e súditos portugueses no Campo Grande, com incorporação das estruturas dos quilombos para instalação da estrutura colonial do Estado português.

Nesse capítulo apresentamos as análises de cada um dos documentos manuscritos selecionados para constituição do corpo central dessa investigação, explorando os elementos neles apresentados com o mínimo de interferência de outras fontes primárias ou secundárias, buscando informações provenientes de elementos externos apenas onde eles foram imprescindíveis para o esclarecimento de pontos que surgiram nos documentos.

A apresentação dos documentos segue ordem cronológica inversa, sendo analisados do mais recente para o mais antigo. 
As edições paleográficas dos textos dos documentos iconográficos (mapas e desenhos), que se encontram junto às suas respectivas análises, foram realizadas pessoalmente, procurando seguir as normas técnicas para transcrição de manuscritos de $1993^{1}$, preservando a grafia original das palavras.

Assim, na análise de cada documento mantivemos os nomes próprios de rios, serras, quilombos, arraiais e outros conforme aparecem nos mesmos, ainda que existam divergências ortográficas de locais em comum entre os mapas estudados na pesquisa.

Há também divergências de grafia dos mapas analisados em relação à publicação dos diários da campanha de Pamplona nos Anais da Biblioteca Nacional, que se devem às diferenças nos critérios paleográficos adotados. Como os documentos da expedição de 1769 são as fontes primárias centrais desta pesquisa, nas análises gerais priorizamos a utilização dos topônimos conforme surgem nos desenhos dessa campanha de Pamplona.

Para viabilizar a leitura dos documentos incluímos chamadas para as transcrições nos mapas editados e também nas análises dos mesmos (mantendo a numeração existente nos manuscritos e acrescentando outras identificações entre colchetes para os demais textos da imagem). As edições dos documentos iconográficos podem ser vistas no fim subcapítulos onde foram analisados.

Para possibilitar a interpretação dos documentos em conjunto, construímos um mapa sobre base atual que unifica os dados extraídos das cartografias históricas. Os critérios utilizados para execução desse mapa atual são apresentados mais à frente.

\footnotetext{
${ }^{1}$ ARAÚJO, Roberto Jorge Chaves. Normas técnicas para transcrição e edição de documentos manuscritos, sistematizadas pela Comissão de Sistematização e Redação do II Encontro Nacional de Normatização Paleográfica. São Paulo: 16 e 17 de setembro de 1993. Disponível em: $<$ http://www.al.pb.leg.br/elegispb/wpcontent/uploads/2013/08/TEXTO_DO_PROF._DR._ROBERTO_JORGE_CHAVES_ARAUJO1.pdf> Acesso em nov. 2018
} 


\section{1 - MAPPA DA CONQUISTA DO MESTRE DE CAMPOS REGENTE CHEFE DA LEGIÃO IGNACIO CORREYA PAMPLONA [ca.1784]}

A recuperação da história dos quilombos no Campo Grande no século XVIII tem no "Mappa da Conquista do Mestre de Campos Regente Chefe da Legião Ignacio Correya Pamplona" (M01) uma fonte valiosa ${ }^{2}$. Executado na década de 1780, esse registro de possessões portuguesas na América representa a região ao norte do rio Grande onde nascem os rios atualmente chamados de São Francisco, Paranaíba, Quebra-Anzol, Araguari e afluentes dos mesmos, localizando nessa zona as estradas, destacamentos militares, cinco povoações luso-americanas e treze quilombos destruídos por diferentes expedições.

Tal peça cartográfica nos é hoje acessível devido o trabalho do Projeto Resgate, que buscou documentos relativos ao atual território brasileiro no Arquivo Histórico Ultramarino (fundo que reúne documentos da administração imperial lusitana no globo terrestre entre o século XVI e início do século XIX). É possível que o mapa estivesse originalmente anexado a relatórios ou cartas, que hoje não nos são acessíveis.

Nesse subcapítulo, que se dedica especificamente ao "Mappa da Conquista do Mestre [...] Pamplona", usamos os topônimos conforme eles aparecem nesse documento. Uma vez que não há acesso ao documento original, esse documento cartográfico foi analisado nesse trabalho através de suas reproduções ${ }^{3}$. Indistinguíveis nas fotografias, o tipo de suporte, tintas usadas e outras características materiais do manuscrito são descritas pelo catálogo da coleção organizado por Maria Dulce de Faria ${ }^{4}$. Segundo tal inventário, esse mapa de folha única foi desenhado a nanquim com detalhes aquarelados, com textos escritos em nanquim e tinta ferrogálica, sendo feito sobre papel que apresenta marca d'água da D\&C Blauw. O uso de papel de trapo importado para suporte do mapa, assim como a alta qualidade do acabamento do desenho demonstram a importância do documento para seus produtores e destinatários.

\footnotetext{
${ }^{2}$ Outra versão de analise desse mapa foi apresentada por geógrafos em simpósio cartográfico. Ver: SILVA FILHO; AMORIM FILHO; CASTRO. A contextualização histórica e geográfica dos quilombos do campo grande. In: I Simpósio Brasileiro de Cartografia Histórica, 2011, Paraty, Rio de Janeiro. Anais [...].

${ }^{3}$ Fotografia de Caldas e Cintra. In: COSTA; FURTADO; RENGER; SANTOS. Cartografia das Minas Gerais: Da capitania à fronteira. Belo Horizonte: Ed. UFMG, 2002.

${ }^{4}$ FARIA, Maria Dulce de. Catálogo da Coleção Cartográfica e Iconográfica Manuscrita do Arquivo Histórico Ultramarino. Rio de Janeiro: Museu de Astrofísica e Ciências Afins, 2011. p.1720, 225-226.
} 
Adiante examino tal mapa buscando decifrar a localização dos quilombos e a importância dos mesmos para os produtores e destinatários do documento.

\subsection{1 - Título, assuntos, produção e cronologia do "Mappa da Conquista [...] "}

O título "Mappa da Conquista do Mestre de Campos Regente Chefe da Legião Ignacio Correya Pamplona" aparece destacado no cartucho na parte inferior esquerda do documento (ver mapa M01). Junto a ele, à direita, vemos a indicação de escala gráfica em léguas $^{[\mathrm{AC}]}$ e a rosa dos ventos com norte apontando para baixo.

Na margem superior há uma inscrição ${ }^{[\mathrm{AB}]}$ que o identifica como uma "Fiel copia" de um mapa que foi entregue a Luiz da Cunha de Menezes (a quem era atribuído o título de conde de Lumiares, que foi governador da capitania de Minas Gerais entre anos 1783 e 1788). Segundo essa anotação, Menezes teria implantado, na região da "Conquista do Campo grande" e em suas anexas na Comarca do Rio das Mortes, uma legião compostas de dois regimentos, de cavalaria e infantaria, e catorze esquadras do mato. Tais destacamentos militares teriam sido criados no ano de 1784, possível data de produção desse manuscrito.

Estamos, portanto, observando um registro oficial do Estado português, cujo mapa original foi destinado ao governador da capitania de Minas Gerais e essa cópia (com a qual lidamos) foi enviada para a administração central do império ultramarino lusitano. O título do mapa aponta Ignacio Correya Pamplona como regente dessa legião e, considerando a ênfase que esse registro deu aos seus feitos, tal Mestre de Campos também devia estar relacionado à produção desse manuscrito.

\subsection{2 - Geografia}

A hidrografia e marcos do relevo são destaques no mapa. Os principais cursos d'água representados são as nascentes do rio de São Francisco ${ }^{[\mathrm{F00]}}$ e do rio "Pernaiba"[P00] (atual Paranaíba), o rio "Santa Fê",[S00] (atuais rios de São João e Quebra-Anzol) e parte do rio Grande ${ }^{[\mathrm{G} 00]}$, juntamente com seus respectivos afluentes. Entre as serras identificadas estão a "Serra da Canastra",[n] ou "Serra da Castra"(№23), "Serra da Marçela"(№22), "Serra do

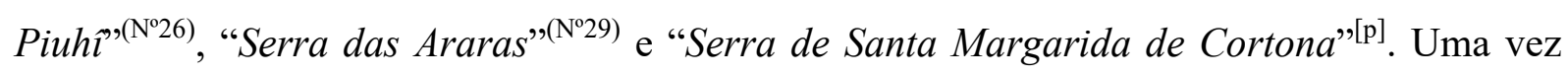
que muitos desses topônimos se mantiveram similares ainda hoje, os elementos da paisagem 
natural são referências fundamentais para localização dos demais elementos como arraiais, quilombos, estradas e outros.

Ao centro o mapa temos o rio de São Francisco ${ }^{[\mathrm{F00}]}$ dividindo a imagem em duas partes. Na metade leste da imagem vemos a vila nova de Tamandoâ ${ }^{\left(N^{\circ} 2\right)}$ (atual Itapecerica) e a matriz da Senhora do Livramento do Piuhî $\hat{(N o}^{\left({ }^{\circ} 11\right)}$, dezessete capelas e mais três quilombos próximos de Piuhî. Na parte oeste temos o arraial do Rio das Velhas ${ }^{\left(\mathrm{N}^{\mathrm{4}} 48\right)}$ (na região do atual Desemboque), a Matriz de Santa Anna de Bamboy $\hat{y}^{\left(\mathrm{N}^{\circ} 20\right)}$ e o arraial de Piracatû ${ }^{\left(\mathrm{N}^{\circ} 44\right)}$ (estando o $^{\circ}$ último ao norte do rio Pernaiba ${ }^{[\mathrm{P} 00]}$ ), além de quatro destacamentos militares, seis fazendas (uma delas na margem sul do rio Grande, no canto superior do desenho), três "Gentio"[Gg] e dez quilombos.

No mapa não há maior esclarecimento sobre o que seriam esses três locais apontados para os gentios. O documento não informa se eram aldeamentos de grupos indígenas aliados da coroa lusitana que foram instalados nessas áreas pelo Estado português ou se, ao contrário, referiam às áreas habitadas por "gentios bravos", nome que os luso-americanos davam aos seus inimigos autóctones, que deviam ser combatidos por suas expedições bélicas.

Outros elementos presentes no documento são os marcos de fronteiras, que reivindicavam essas áreas para as capitanias de Goŷas ${ }^{[\mathrm{Mb}]}$ ou de Minas Gerais ${ }^{[\mathrm{Ma}, \mathrm{Mc}]}$ e as estradas que atravessavam a região. Adiante descrevo a rota desses caminhos de acordo com o mapa, cujos trajetos reforçamos na imagem M01b.

\subsection{3 - Caminhos terrestres}

A Picada de Goŷas ${ }^{[\mathrm{c}]}$ (em verde claro no M01b) vinha do sudeste, atravessando os rios

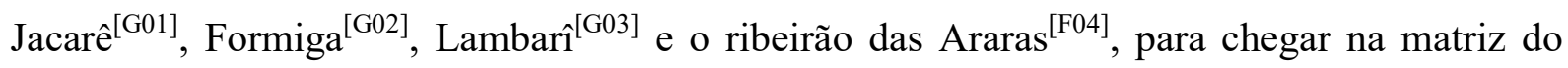
Piuhî $\hat{(N}^{\left(\mathrm{N}^{\circ} 11\right)}$. A picada, então, atravessava o rio de São Francisco ${ }^{[\mathrm{F} 00]}$, passava pelo quilombo $\mathrm{N}^{\mathrm{o}} 33$ ao pé da serra da Marçela ${ }^{\left(\mathrm{N}^{\circ} 22\right)}$, seguindo pela margem nordeste do rio Santa $\mathrm{Fe}^{[\mathrm{S} 04]}$ (atuais rios São João e Quebra-Anzol), passando pelo quilombo do Ambrozio ${ }^{(43)}$ (perto do rio de Santa Tereza ${ }^{[\mathrm{S} 03]}$ ) e pelo quilombo $\mathrm{N}^{\circ} 39$ (que ficava próximo ao ribeirão dos Dourados $\left.^{[\mathrm{P} 01]}\right)$, cruzava o rio Pernaiba ${ }^{[\mathrm{P} 00]}$, chegava ao arraial do Piracatû ${ }^{\left(\mathrm{N}^{\circ} 44\right)}$ e dali seguia rumo noroeste. Nas vizinhanças da picada de Goŷas foram representadas cinco capelas ao leste do rio de São Francisco e, ao oeste do mesmo rio, mais cinco fazendas, dois gentios ${ }^{[\mathrm{Gg}]} \mathrm{e}$ dois destacamentos militares ${ }^{\left[\mathrm{Dc}, \mathrm{N}^{\circ} 40\right]}$. 
O caminho que vinha da vila de São Josê ${ }^{[a]}$ (em ciano) teve parte de seu percurso representado no desenho. Nesse trecho, a estrada corria próxima da margem norte do rio Grande $\mathrm{e}^{[\mathrm{G} 00]}$, se juntado à picada de Goŷas ${ }^{[\mathrm{c}]}$ nos arredores da matriz de Piuhî ${ }^{\left(\mathrm{N}^{\circ} 11\right)}$. Ao longo dele foram indicadas três capelas. Essa trilha também se conectava à estrada de Goŷas através de dois caminhos secundários (tracejados em verde), junto aos quais também havia capelas.

O arraial do Rio das Velhas ${ }^{\left({ }^{\circ} 48\right)}$ e a matriz de Piuhî ${ }^{\left(N^{\circ} 11\right)}$ eram conectados por uma estrada $^{[\mathrm{m}]}$ (em amarelo) que corria por sobre a serra da Canastra ${ }^{[\mathrm{n}]}$. O arraial ficava junto ao rio das Velhas ${ }^{[\mathrm{G} 17]}$, que nesse mapa foi retratado como afluente do rio Grande ${ }^{[\mathrm{G} 00]}$. Junto desse caminho foram assinalados um destacamento militar ${ }^{[D e]}$ e um marco posto pela capitania de Minas Gerais ${ }^{[\mathrm{Mc}]}$. Não tão distante dessa estrada, entre o rio Grande, a serra do Piuhî ${ }^{\left(\mathrm{N}^{\circ 26}\right)}$ e o rio de mesmo nome ${ }^{[\mathrm{G} 04]}$ (que aqui também aparece como afluente do rio Grande), estava o quilombo $\mathrm{N}^{\circ} 41$.

A “estrada" feita por Pamplona ${ }^{[\mathrm{d}, \mathrm{o}]}$ (em vermelho) vinha das vizinhanças da vila de São Josê se juntava à picada de Goŷas ${ }^{[\mathrm{c}]}$ perto do rio Lambarî ${ }^{[\mathrm{G} 03]}$, havendo uma capela ${ }^{\left(\mathrm{N}^{\circ} 10\right)}$ no entroncamento desses dois caminhos. O caminho de Pamplona também se ligava nessa região à estrada de Goŷas por duas trilhas complementares que atravessavam vertentes do rio Jacare $^{[\mathrm{G} 01]}$, com capelas ${ }^{\left(\mathrm{N}^{\circ} 1, \mathrm{~N}^{\circ} 3 \text { e } \mathrm{N}^{\circ} 4\right)}$ nas proximidades de ambas. Depois de passar o rios do Piui ${ }^{[\mathrm{G} 04]}$ e de São Francisco ${ }^{[\mathrm{F} 00]}$, a estrada feita "pessoalmente pelo Mestre de Campos para se conheçer estas vertentes no Sentro da Capitania" ${ }^{[0]}$ se distanciava da picada de Goŷas, indo em direção a serra da Canastra ${ }^{[\mathrm{n}]}$ até as margens do ribeirão de Santo Antonio ${ }^{[\mathrm{F} 01]}$, onde estava o quilombo $\mathrm{N}^{\circ} 32$. Seguia até as nascentes de afluentes do rio das Velhas ${ }^{[\mathrm{G} 17]}$ e voltava a encontrar a picada de Goŷas perto do rio da Perdição ${ }^{[\mathrm{F} 12]}$ ao pé da serra da Marçela ${ }^{\left[\mathrm{N}^{\circ} 22\right]}$. O caminho de Pamplona seguia, então, pela margem nordeste do rio de Santa Fê ${ }^{[\mathrm{S} 00]}$, passando pelo quilombo do Ambrozio ${ }^{(43)}$, pelo quilombo $\mathrm{N}^{\mathrm{o}} 36$ e por um gentio ${ }^{[\mathrm{Gg}]}$, até o marco que dividia as capitanias de Minas Gerais e de Goŷas ${ }^{[\mathrm{Mb}]}$. A trilha margeava a serra de Santa Margarida de Cortona ${ }^{[\mathrm{p}]}$ até o ribeirão dos Dourados ${ }^{[\mathrm{P} 01]}$, acompanhava o rio do Salitre até o quilombo No38 e, nas proximidades desse, se ligava novamente à picada de Goŷas.

Assim, segundo esse mapa, o caminho feito por Pamplona passava por três quilombos destruídos por ele ${ }^{\left(N^{\circ} 32, N^{\circ} 36, N^{\circ} 38\right)}$, e pelo quilombo do Ambrozio. O quilombo №37 (também arrasado pelo Mestre de Campos) estava fora da rota da estrada feita por Pamplona ${ }^{[0]}$, sendo localizado entre os rios Santa Fe ${ }^{[\mathrm{S} 00]}$, Turvo ${ }^{[\mathrm{S} 09]}$, de São Hipolito ${ }^{[\mathrm{S} 10]}$ e a Serra das $\operatorname{Araras}^{\left(\mathrm{N}^{\circ 29)}\right.}$. 
A vila de Tamandoâ ${ }^{\left({ }^{\circ} 2\right)}$ se ligava à matriz de Bamboŷ ${ }^{\left({ }^{\circ} 20\right)}$ por um caminho (em azul escuro) que atravessava o rio de São Francisco ${ }^{[\mathrm{F00]}}$ perto da confluência com o ribeirão de São Miguel $^{[\mathrm{F} 05]}$. Passava por Bamboŷ e, então, se agregava à picada de Goŷas ${ }^{[\mathrm{c}]}$ no ponto onde havia o quilombo No33 (destruído pelos “Boinos"). Nas margens dessa trilha, a leste do rio de São Francisco, havia duas capelas.

A estrada para o rio de São Francisco ${ }^{[\mathrm{e}]}$ (em rosa) cruzava uma vertente de tal curso d'água (rio Parâ ou Pará) seguindo para norte. Antes de atravessar o rio Parâ, esse caminho se bifurcava duas vezes (perto das capelas $\mathrm{N}^{\mathrm{o}} 16$ e $\mathrm{N}^{\mathrm{o}} 17$ ) para se conectar a vila de Tamandoâ ${ }^{\left(\mathrm{N}^{\circ} 2\right)}$. Saindo de Tamandoâ, a trilha seguia na margem nordeste do ribeirão de Santa $\mathrm{Ana}^{[\mathrm{F09]}}$ (possivelmente o atual ribeirão de Santa Luzia), passava por uma capela e se dividia novamente em dois braços antes de cruzar o rio de São Francisco.

Um era a estrada para São Romão ${ }^{[\mathrm{g}]}$ (também em rosa) passava pelo quilombo $\mathrm{N}^{\mathrm{o}} 42$ (destruído por Pamplona), atravessava o leito dos rios Andaŷa ${ }^{[\mathrm{F} 16]}$, Abaitê ${ }^{[\mathrm{F} 20]}$ e seguia para norte nas margens do rio de São Francisco ${ }^{[\mathrm{F} 00]}$. Não distantes desse caminho, nas margens de tal rio, foram indicados dois destacamentos militares e um marco da câmara de S. José [Ma] $^{[\mathrm{M}}$ (instância da administração civil integrante da capitania de Minas Gerais).

Outra vertente era a estrada para Piracatú ${ }^{[j]}$ (em verde escuro) que, depois de atravessar o São Francisco, margeava o rio da Perdição ${ }^{\left[{ }^{[12]}\right.}$ rumo sudoeste em direção do quilombo No34 (arrasado pelos "Boinos") para dali mudar seu curso, seguindo rumo noroeste perto das nascentes dos rios Andaŷa ${ }^{[\mathrm{F} 16]}$ e Abaite $\hat{e}^{[\mathrm{F} 20]}$, se agregando à picada de Goŷas na margem nordeste do rio Pernaiba ${ }^{[\mathrm{P} 00]}$, ao pé da serra dos Paulistas ${ }^{\left(\mathrm{N}^{\circ} 38\right)}$. No lado oposto dessa serra estava implantado um destacamento militar $^{[\mathrm{Dc}]}$.

\subsection{4 - Caminhos, hidrografia, povoados e destacamentos militares}

Ao mesmo tempo em que os caminhos terrestres tiveram suas rotas bastante detalhadas, não há indicação de portos ou uso de navegação fluvial nesse mapa. Compreendemos, por isso, que a locomoção nessa zona era feita por terra, através de caminhos que margeavam e atravessavam os muitos rios e ribeirões da região, que deviam servir como fornecedores de água para os viajantes.

Na ilustração do mapa, no entanto, todas essas estradas foram traçadas com sutileza (com linhas pontilhadas e finas), em contraste com a paisagem natural, que apresenta desenho 
bem mais visível (com os rios representados com linhas duplas grossas e as serras com sombreado). Tal delicadeza no desenho dos caminhos sugere alguma dificuldade de identificação desses no ambiente ${ }^{5}$, enquanto a hidrografia e relevo foram eleitos pelos próprios produtores do mapa como os principais elementos de referência para o reconhecimento dessa zona.

Há um contraste significativo entre os elementos apresentados nas duas metades da imagem, dividida ao meio pelo rio de São Francisco ${ }^{[\mathrm{F} 00]}$.

Como vimos, na metade leste do mapa os caminhos estavam envoltos por mais de uma dezena de capelas e por duas povoações subordinadas à coroa ibérica (Tamandoâ e Piuhî). Foram identificados três quilombos nessas partes, dois deles junto a nascentes de ribeirões afluentes do rio de São Francisco (N³0 e N³1, destruídos por Pamplona) e um outro entre o rio Grande ${ }^{[\mathrm{G} 00]}$ e rio de Piuî ${ }^{[\mathrm{G} 04]}\left(\mathrm{N}^{\circ} 41\right.$, destruído em 1764). Não foram indicados gentios ou postos militares nesse lado leste do mapa.

$\mathrm{Na}$ metade oeste do desenho, as estradas tinham suas rotas pontuadas por três povoados luso-americanos (Rio das Velhas ${ }^{\mathrm{N}^{\circ} 48}$, Bamboy $\hat{\mathrm{N}}^{\mathrm{N} 20}$ e Piracatû ${ }^{\mathrm{N}^{\circ} 44}$ ), oito quilombos, três gentios e cinco postos militares. Não há indicação de capelas nessa região.

Todos os seis destacamentos militares indicados estão no lado oeste do mapa, aparecendo nas margens de rios ${ }^{\left[\mathrm{Da}, \mathrm{Db}, \mathrm{N}^{\circ} 40\right]}$ ou junto às serras ${ }^{[\mathrm{Dc}, \mathrm{Dd}, \mathrm{De}]}$. Possivelmente, a dita legião que teria sido criada nessa região em 1784 segundo a anotação ${ }^{[\mathrm{AB}]}$ (composta por cavalarias, infantarias e esquadras do mato), se referisse a um ou mais desses destacamentos do desenho. Apenas dois postos militares aparecem próximos de estradas, estando um sobre a serra da Canastra ${ }^{[\mathrm{De}]}$ e outro junto ao rio de São $\operatorname{Marcos}^{\left[\mathrm{N}^{\circ} 40\right]}$. Os demais destacamentos ou estavam localizados no lado oposto das serras onde passavam as estradas, ou estavam mais próximos dos rios do que dessas rotas. Dessa maneira, entendemos que a escolha de local para a implantação desses agrupamentos bélicos não priorizava a coincidência com as estradas.

Já as cinco povoações luso-americanas e oito dos quilombos aparecem diretamente relacionados às estradas nesse mapa. A picada de Goŷas ${ }^{[\mathrm{c}]}$ (em verde claro), entre Piuhî e

\footnotetext{
${ }^{5}$ Muitos dos caminhos em meio aos sertões não passavam de estreitas picadas abertas nas matas, que desapareciam facilmente depois de algum tempo sem uso, por isso os rios serviam de meios de orientação. Ver: HOLANDA, Sérgio Buarque de. Caminhos e Fronteiras. Rio de Janeiro: Ed. José Olympio, 1957. p.15-37.
} 
Piracatû, passava por 3 quilombos $\left(\mathrm{N}^{\circ} 33, \mathrm{~N}^{\circ} 39\right.$ e 43) e dois gentios. O caminho para Piracatú $^{[\mathrm{j}]}$ (em verde escuro) passava pelo quilombo $\mathrm{N}^{\mathrm{o}} 34$. A estrada de Pamplona ${ }^{[\mathrm{d}, \mathrm{o}]}$ (em vermelho) saindo de Piuhî rumo noroeste, atravessava um gentio e quatro quilombos ( $\mathrm{N}^{\mathrm{o}} 32$, $\mathrm{N}^{\mathrm{o}} 36, \mathrm{~N}^{\mathrm{o}} 38$ e 43). A estrada para São Romão ${ }^{[\mathrm{g}]}$ (em rosa) passava por Tamandoâ e atravessava o quilombo Nº42. O caminho que ligava Tamandoâ com Bamboŷ (em azul escuro) culminava no quilombo $\mathrm{N}^{\mathrm{0}} 33$.

Fora das rotas dessas estradas estavam, na face oeste, os quilombos №37 e o Andaŷa No35 e, a leste, os quilombos N³0, º31 e Nº41 próximos do povoado de Piuhî. Apesar de não serem atravessados pelas estradas, tais quilombos estavam a poucas léguas de distância das mesmas.

Fica a questão sobre quais foram os elementos precursores nessa região. Teriam primeiro se assentados os arraiais e vilas luso-americanos e suas respectivas estradas e, depois desses se consolidarem, teriam sido erguidas as povoações quilombolas às suas margens, sendo posteriormente destruídas? Se esse foi o caso, por que os quilombos ficariam tão próximos da circulação de seus inimigos? Por facilidade de acesso para fuga de escravizados, viabilização de comércio clandestino com povoados luso-americanos, assalto de viajantes nas estradas? Ou os quilombos teriam se estabelecido primeiro nessa zona, sendo demolidos e apropriados para construção das estradas e povoados subordinados à coroa ibérica? Por que juntamente a esses dois tipos de povoações rivais e às vias de acesso, também são mostrados no mapa algumas fazendas, capelas, gentios e destacamentos militares?

O documento deu ênfase aos responsáveis pela destruição dos quilombos assinalados. Somente os quilombos $\mathrm{N}^{\mathrm{o}} 35, \mathrm{~N}^{\mathrm{o}} 41$ e 43 (Ambrozio) não tiveram seus exterminadores nomeados. De acordo com esse documento, a destruição dos quilombos No33, N³4 e No39 foi de responsabilidade dos "Boinos". Já os quilombos No30, No31, N³2, N³6, N³7, N³8 e No42 (total de sete povoados) teriam sido destruídos pelo "Mestre de Campos Regente" Pamplona.

Como vimos, o mapa indica Pamplona como autor de uma das estradas (que passa por três dos quilombos que o próprio Mestre de Campos destruiu) e, também, como chefe da legião militar que estava sendo criada em 1784 a mando do governador da capitania de Minas Gerais. 
A forte presença de sua figura no documento sugere que Pamplona tenha encomendado esse mapa para destiná-lo à administração do Estado português. Contudo, por que ele realizaria as atividades de destruir quilombos e construir estradas, assim como produzir um documento que identificasse os locais onde ele e outros atuaram? Por qual motivo a localização dessas estradas, quilombos e outros foram apresentados nesse manuscrito?

O fato de o mapa ter sido entregue para o governador e para o conselho ultramarino (e ter sido conservado nos arquivos do último), mostra o interesse das instituições da coroa lusitana nessa zona do "Campo grande e sua anexas da Comarca do Rio das Mortes" em fins do século XVIII. Que interesses seriam esses? Como podemos entender a "Conquista" que está sendo apresentada por esse mapa?

Adiante busco explorar tais questões trazidas a partir da leitura do mapa, procurando entender os elementos que surgiram no documento com o auxílio de outras fontes.

\subsection{5 - Cronologia dos confrontos pelo povoamento e exploração do Campo Grande}

Citados no "Mappa da Conquista [...]" como destruidores de quilombos, tanto Bartolomeu Bueno do Prado e sua família (os "Boinos") quanto Ignacio Correya Pamplona comandaram diferentes expedições militares que adentraram os sertões do Campo Grande, sob ordens de governadores da capitania de Minas Gerais, para combater os "inimigos da coroa" e promover o povoamento da região com seus súditos.

As incursões de tropas luso-americanas contra quilombolas foram recorrentes na região, sobretudo entre as décadas de 1740 e 1770. Os principais participantes dessas expedições costumavam receber sesmarias e mercês em troca dos serviços prestados à coroa Bragança.

Podemos compreender um pouco da cronologia dos conflitos entre agentes lusitanos, quilombolas e indígenas nessa zona através de trabalhos de pesquisadores que analisaram os processos de povoamentos e disputas pelo domínio dessa região no século XVIII a partir de documentos oficiais da administração portuguesa. 
As regiões do Alto do São Francisco e do Alto Paranaíba foram ocupadas por índios Tremembé que se instalaram em terras entre o rio das Velhas e Quebra-Anzol (rio de Santa $F \hat{e}^{[S 00]}$, sendo conhecidos por ali por Cataguá ou Araxá. No século XVII, com a migração de índios Kayapó para a região que hoje chamamos de triângulo mineiro, os dois grupos entraram em conflito pelo domínio desses espaços, resultando no predomínio dos Kayapó. Essas áreas sofriam ataques de bandeirantes para captura de índios (levados como escravizados para outras regiões) até que, nos últimos anos do século XVII, tal zona passa a ser visada por súditos portugueses para pecuária. No entanto, as ações guerreiras dos Kayapó bloqueavam o estabelecimento desses. ${ }^{6}$

Quanto à presença de quilombolas nessa região conhecida então por Campo Grande, podemos identificar a presença de quilombos pelo menos desde a década de 1720, através de documentos oficiais do Estado colonial português ${ }^{7}$. É possível que o estabelecimento de quilombos nessa zona fosse anterior, mas não restaram documentos que não de seus inimigos para confirmação de datas mais precisas.

Os primeiros focos de povoamentos luso-americanos no interior do continente se deveram à exploração aurífera. Esses surgiram primeiramente na serra do Espinhaço, com exploração iniciada ali nos últimos anos do século XVII. Mais a oeste, entre as primeiras e mais prósperas jazidas descobertas, estavam as de Pitangui (próximo da região estudada, com ouro encontrado em 1711) e as de Goiás (mais distante dos locais analisados, descoberta em 1725). Algumas minas auríferas prosperavam anos e se estabeleceram algumas aglomerações urbanas derivadas delas, outras não apresentavam minério em volume satisfatório e eram abandonadas rapidamente. ${ }^{8}$

\footnotetext{
${ }^{6}$ VENÂNCIO, Renato Pinto. Antes de Minas: fronteiras coloniais e populações indígenas. In: RESENDE; VILLALTA (org.). As Minas Setecentistas, vol.1. Belo Horizonte: Autêntica; Companhia do Tempo, 2007. p.87-102.

${ }^{7}$ O Gomes Freire falava em carta de 1746 sobre quilombo no Campo Grande com mais de 20 anos, que governador especulava ter mais de mil habitantes. Ver: BARBOSA, Waldemar. Negros e quilombos em Minas Gerais. Belo Horizonte: 1972. p.32.

${ }^{8}$ BARBOSA, Waldemar de Almeida. A decadência das Minas e a fuga da mineração. Belo Horizonte: Imprensa da Universidade Federal de Minas Gerais, 1971, p. 27-30;

FONSECA, Cláudia Damasceno. Arraiais e vilas d'el rei: espaço e poder nas Minas setecentistas. Tradução de Maria Juliana G. Teixeira. Belo Horizonte: Ed. UFMG, 2011. p.63-77.
} 
Não sendo encontrado ouro em quantidades significativas na região das nascentes das bacias do rio de São Francisco e Paranaíba, o povoamento dessas áreas por luso-americanos foi decorrente da busca de terras para agricultura e criação de gado (fosse para abastecimento das áreas mineradoras, ou em decorrência da decadência da extração aurífera em outras regiões, resultando na busca de economias alternativas). As incursões de agentes da coroa lusitana nessas áreas foram iniciadas na década de 1730 e seus povoados só puderam se estabelecer décadas depois, a partir de meados do século XVIII. ${ }^{9}$

Apesar do interesse da metrópole pela extração de ouro na América e ainda que muitas dessas expedições sabidamente tenham buscado ouro nessas paragens, o mapa não indica qualquer jazida. A partir da bibliografia estudada, identificamos que três dos povoamentos luso-americanos assinalados no documento tiveram origem em função da descoberta de ouro: o arraial do Rio das Velhas ${ }^{\left[\mathrm{N}^{\circ} 16\right]}$, Piracatû ${ }^{\left[\mathrm{N}^{\circ} 4\right]}$ e Piuhî ${ }^{\left[\mathrm{N}^{\circ} 11\right]}$.

As primeiras faisqueiras no Piuhî foram encontradas em 1731, mas o volume de ouro naquele momento estava muito abaixo do esperado, não tendo prosperado sua exploração. Para conectar as fartas minas auríferas da serra do Espinhaço às de Goiás, foi emitida uma ordem régia em 1736 para abertura de estrada entre ambas, com extermínio de seus inimigos junto à mesma. Um das "Picadas de Goiás" (nome dado a diferentes estradas que conectavam as minas de Goiás e Minas Gerais) atravessava a região entre Formiga ${ }^{[\mathrm{G} 02]}$, Piuhî ${ }^{\left[{ }^{\circ} 11\right]}$. Os responsáveis por abrir tal picada receberam a concessão de sesmarias na região de Piuhî em 1737, como contrapartida aos serviços prestados ao rei lusitano. Esses sesmeiros, no entanto, poucos anos depois abandonaram a área devido à ação de quilombolas, que rivalizavam com eles pelo povoamento daquela área. ${ }^{10}$

Em 1741 uma ordem do governador da capitania de Minas Gerais apresentou queixa contra negros que assaltavam e matavam súditos lusitanos, fazendo com que os sesmeiros abandonassem suas terras. Tal bando ordenava que capitães-mores e oficiais da milícia do distrito do sertão combatessem os quilombos. Em 1743 foram empreendidos fortes ataques contra os quilombos na região de Formiga $^{[\mathrm{G} 02]}$ e Piuhî ${ }^{\left[\mathrm{N}^{\circ} 11\right]}$, sendo, então, concedidas sesmarias nesse "deserto sertão que até agora servia de couto a negros aquilombados que ali se achavam com grande poder" ". Houve uma nova notícia de ouro no Piuhî em 1754, o que

\footnotetext{
${ }^{9}$ BARBOSA, 1971, p.13-63.

${ }^{10}$ BARBOSA, 1971, p.27-36; VENÂNCIO, op.cit., p.99.

${ }^{11}$ Arquivo Público Mineiro (APM cód. 90 fl.37).
} 
provocou uma corrida de aventureiros até o local mas, por fim, esse povoado não chegou a ser um relevante produtor aurífero. ${ }^{12}$

As minas de Piracatû (atual Paracatu) foram descobertas em 1744, estando entre as mais prósperas até o início dos anos $1780^{13}$. Como vemos no mapa, Piracatû ${ }^{\left[\mathrm{N}^{\circ} 44\right]}$ concentrava boa parte das rotas que ligavam o leste do alto São Francisco com as minas goianas. Sendo assim, os interesses luso-americanos sobre Piracatû estavam relacionados à mineração e à sua posição na rota de comunicação entre regiões auríferas.

A partir de 1745 o número de pedidos de sesmarias nas regiões do Piuhî, serra da Marçela, "sertões" do Bamboî e arredores se tornaram significativos. De acordo com o historiador Waldemar Barbosa, há documentos que indicam que a região entre os rios de São Francisco e Lambari (junto à Tamandoâ) não era trilhada por súditos portugueses até a metade da década de 1750, documentos esses que associam o combate de "negros quilombolas" com o povoamento da região por luso-americanos através do estabelecimento de fazendas de gado. Muitos desses pedidos de sesmarias foram feitos por indivíduos dedicados à exploração aurífera, demandando terras produção de alimentos para abastecimento daquela atividade.

Sendo assim, somente a partir de meados das décadas de 1740 ou de 1750 que súditos da coroa Bragança começaram a estabelecer fazendas para agricultura e pecuária nas imediações de Piuhî ${ }^{\left[\mathrm{N}^{\circ} 11\right]}$, Tamandoâ ${ }^{\left[\mathrm{N}^{\circ} 2\right]}$, serra da Marçela ${ }^{\left[\mathrm{N}^{\circ} 22\right]}$. A colonização luso-americana se estabeleceu nessa parte leste das cabeceiras do rio de São Francisco após uma guerra de grandes proporções contra os quilombolas da região travada a partir de 1746. No entanto, a formação de quilombos continuava ocorrendo, se concentrando agora na margem ocidental do São Francisco. ${ }^{14}$

As faisqueiras de ouro no arraial do Rio das Velhas ${ }^{\left[\mathrm{N}^{\circ} 48\right]}$ foram descobertas em 1756 pela expedição comandada por Bartolomeu Bueno do Prado (por um dos "Boinos", portanto). Situada para além da serra da Canastra, a exploração aurífera do Rio das Velhas era impedida pela presença de negros aquilombados e índios Kayapó na região. Foi então preparada uma expedição pelas câmaras das imediações para combater tais "inimigos da colonização lusitana", reunindo recursos e tropas por três anos para então adentrar aqueles sertões, saindo

\footnotetext{
${ }^{12}$ BARBOSA, 1971, p.30-36.

${ }^{13}$ BARBOSA, 1971, p.20.

${ }^{14}$ Dados extraídos de documento do acervo do Arquivo Público Mineiro (APM cód. 129, fl 99 e 100 / APM cód. 156, fl. 8 / APM cód. 172, fl. 16) citado em: BARBOSA, 1971, p.23-36 /p.57-58.
} 
de Piuhi $\hat{1}^{\left[\mathrm{N}^{\circ} 11\right]}$ em agosto de 1759 para combater os quilombos do Campo Grande e tomar posse daqueles sertões além da serra da Marçela. Nessa guerra foram destruídos um quilombo nas margens do rio Bamboŷ (que deve se referir ao quilombo №33 do mapa), um chamado de Andaial (possivelmente o $\mathrm{N}^{\mathrm{o}} 35$ ), o quilombo Grande (também conhecido por Ambrozio ${ }^{(43)}$, onde foram capturadas crianças nascidas ali com até 12 anos de idade), o Pernaíba (que devia ficar junto ao rio de mesmo nome ${ }^{[\mathrm{P} 00]}$ ) e o Endaí. Atravessando novamente para leste do rio de São Francisco, Bartolomeu Bueno queimou os quilombos do Careca e Morro de Angola, ambos na bacia do rio Grande. Em retribuição a seus serviços de extermínio de quilombolas, Bartolomeu Bueno do Prado recebeu sesmaria entre rio Lambari, serra da Esperança, Pouso Alegre e Rio Grande, além de cargo de comandante de São Pedro de Alcantara. ${ }^{15}$

O arraial de Bamboy $\hat{y}^{\left[\mathrm{N}^{\circ 20]}\right.}$ foi fixado somente depois de conquistados os arredores de Piuhî $\hat{\imath}^{\left[\mathrm{N}^{\circ} 11\right]}$, tendo seu estabelecimento relacionado à figura de Ignacio Correya Pamplona. Segundo Barbosa, a primeira expedição de Pamplona para o oeste do rio de São Francisco, para combater índios e negros aquilombados, foi empreendida em 1765. Os combatentes dessa expedição requereram concessão de terras para povoarem aquele "sertão inculto" com fazendas de gado, tendo suas petições deferidas em 1767.

Outra expedição de combate aos quilombos para além da serra da Marçela (ou Marçella) foi liderada por Pamplona em 1769, quando foi lavrado o auto de posse das paragens de Bamboy ${ }^{\left[\mathrm{N}^{\circ 20]}\right.}$ para o termo da vila de São José, integrante da comarca do Rio das Mortes. Correspondências do governador de Minas Gerais para Pamplona e para o vigário de Pitangui, no início dos anos 1770, afirmavam a utilidade, para o "Real Serviço", da fixação de povoamentos nos arredores de Bamboŷ (com cultivo das terras, construção de capelas e igrejas para assistência espiritual dos entrantes e estabelecimento de meios de sua permanência), assim como da descoberta de faisqueiras. ${ }^{16}$

No início da década de 1770, o combate de quilombos na serra Negra (onde nasce o ribeirão do Dourados ${ }^{[\mathrm{P} 01]}$ ) resultou no aprisionamento de mais de 50 negros que foram devolvidos ao cativeiro em Piracatû ${ }^{\left[{ }^{\circ} 44\right]}$, enquanto o responsável pela expedição criou ali uma fazenda que originou o atual município de Patrocínio. Até os anos de 1780, ainda há registros de confrontos contra quilombolas nos arredores de Piracatût ${ }^{\left[\mathrm{N}^{\circ} 4\right]}$ e Bamboy $\hat{y}^{\left[\mathrm{N}^{\circ} 20\right]}$ na

\footnotetext{
${ }^{15}$ BARBOSA, 1972, p.41-53.

${ }^{16}$ Análise de documentos do Arquivo Público Mineiro (APM cód.103, fl.23/ cód.145), apresentada em: BARBOSA, 1971, p.30-39.
} 
documentação da administração pública luso-americana, registros esses que vão rareando nos últimos anos do século XVIII. ${ }^{17}$

O domínio dos índios Kayapó na zona do Campo Grande foi combatido pelos lusoamericanos por pelo menos meio século. Em 1739, sob a liderança de um agente português, foi empreendido um ataque de índios Bororó contra os Kayapó, sendo fixado um quartelaldeamento na região para servir de base aos luso-americanos. Os custos desse combate foram divididos entre as capitanias de Minas Gerais e Goiás. Procurando garantir a segurança dos viandantes e para combate aos índios inimigos na região os agentes portugueses fundaram três aldeias de índios Bororó ao longo do caminho de Goiás e, também, foi enviada outra expedição comandada por Pamplona em $1782 .^{18}$

Como indicado em sua inscrição ${ }^{[\mathrm{AB}]}$, a produção do "Mappa da Conquista [...]" se deu logo após tais eventos de enfrentamentos de grupos indígenas rivais. Assim, os três gentios ${ }^{[\mathrm{Gg}]}$ indicados nesse mapa podem se referir aos locais onde foram destruídos os povoados Kayapó, ou se referem aos tais aldeamentos dos Bororó implantados ao longo da picada de Goŷas pelos agentes lusitanos para proteção dos viandantes. Pela coincidência na quantidade e local dessas aldeias, parece mais provável que os gentios apontados no mapa se refiram a povoados Bororó, indígenas habituais associados aos lusitanos naquelas partes.

De acordo com Guimarães, houve uma mudança na administração do Estado colonial luso-americana na relação com os ameríndios naquele período. Alguns grupos indígenas eram considerados aliados pelos agentes portugueses até 1777, após essa data foram despachadas tropas para combater quilombos e também aldeias ${ }^{19}$. Se esse foi o caso, a expedição de Pamplona de 1782 não teria sido enviada para combater seus rivais Kayapó ou, mas para eliminar as aldeias de seus antigos aliados Bororó.

A auto promoção de Ignacio Correya Pamplona para as autoridades a respeito dos serviços prestados por ele à sua majestade, rendeu-lhe a concessão de sesmarias em seu nome e de seus familiares na região. Ele também recebeu as patentes de Mestre de Campos e

\footnotetext{
${ }^{17}$ BARBOSA, 1971, p.63; BARBOSA, 1972, p.72-75.

${ }^{18}$ BARBOSA, 1972, p.88-89; SOUZA, Laura de Mello e. Norma e conflito: aspectos da História de Minas no século XVIII. Belo Horizonte: Ed. UFMG, 1999. p.83-137; VENÂNCIO, op.cit., p.96-99.

${ }^{19}$ GUIMARÃES, Carlos Magno. Quilombos, classes, estado e cotidiano: Minas Gerais, século XVIII. 1999 f. Tese (Doutorado em História) - Faculdade de Filosofia, Letras e Ciências Humanas da Universidade de São Paulo, São Paulo.1999. p.297.
} 
Regente do Piuhî, Bamboŷ, Campo Grande e picada de Goŷas, se tornando chefe militar e civil dessa ampla zona ${ }^{20}$.

\subsection{6 - Considerações ao "Mappa da Conquista [...]”}

A partir da analise do mapa, compreendemos que a conquista do Campo Grande pelos súditos portugueses foi decorrente da ação bélica de seus agentes ao longo de, pelo menos, cinco décadas. No "Mappa da Conquista [...]" foram destacadas as atuações de Pamplona e dos Buenos na apropriação daquela zona, sendo implantada uma legião militar para a manutenção de seus domínios.

O manuscrito nos permite observar que a circulação de luso-americanos nessas áreas, com estabelecimento de suas povoações, fazendas e aparatos político-religiosos, estavam diretamente associada ao combate de quilombolas e indígenas, que rivalizavam com os primeiros pelo domínio daquele território ao longo do século XVIII.

A conquista da região do Alto São Francisco e Alto Paranaíba pelo império português se deu por diferentes meios, como o envio de tropas para destruir povoações inimigas, estabelecimento de aldeias de ameríndios aliados, instalação de destacamentos militares, abertura de vias de circulação, concessão de terras para seus súditos, construção de igrejas e capelas para assistência espiritual de luso-americanos, implantação de arraiais e vilas. A colonização por súditos portugueses nesses territórios só pode se efetivar através de força militar continua para combate de seus rivais, "negros quilombolas" ou "gentios bravos", lutas que foram travadas ao longo de meio século.

Nesta análise, buscamos definir as épocas de povoamento das áreas pelos diferentes grupos que as disputaram. De maneira geral, os povoados indígenas e quilombolas precederam os dos súditos portugueses nessa zona. Após os primeiros embates entre esses povos rivais, com vitória dos luso-americanos, a fixação dos últimos nos espaços não era irrefutável. Depois de abertas estradas e concedidas sesmarias, os quilombolas e indígenas inimigos podiam tornar a ameaçar os luso-americanos que, por vezes, foram expulsos pela ação daqueles. A permanência da colonização do Estado português nessa zona teve de ser reafirmada através de repetidas investidas militares.

${ }^{20}$ SOUZA, 1999, p.115-117 
A produção do "Mappa da Conquista [...]" devia estar relacionada à negociação de cargos ou reafirmação da importância da contribuição de Pamplona para o estabelecimento da colonização por súditos da coroa Brangança no Campo Grande e imediações. A execução de mapas detalhados por expedicionários que desbravaram aquelas paragens era fundamental para a administração portuguesa (em suas instâncias regionais e metropolitana), meio pelo qual podiam conhecer o território que buscavam conquistar.

Produzido na década de 1780, o contraste apresentado no "Mappa da Conquista [...]" entre os dois lados do São Francisco, demonstra um estabelecimento mais efetivo dos lusoamericanos no leste, com suas muitas capelas e somente três quilombos. No oeste, a destruição recente de dez quilombos, a presença ostensiva de destacamentos militares, contrapostos à ausência de capelas (marco da presença da coroa Bragança tanto quanto da igreja), são dados que revelam que a apropriação daqueles espaços estava ainda em curso.

As construções religiosas marcavam o domínio da igreja católica e, por consequência, também da coroa portuguesa a ela associada através do padroado régio na América. Já os marcos de divisa assinalados ${ }^{[\mathrm{Ma}, \mathrm{Mb}, \mathrm{Mc}]}$ separavam o território para essa ou aquela divisão administrativa, demarcações que indicam também que tal área estava sendo disputada entre as capitanias, comarcas ou câmaras.

O detalhamento das estradas no "Mappa da Conquista [...]" evidencia a importância dessas vias de circulação no processo de apropriação dos espaços pelo Estado português. A coincidência das estradas na região com os quilombos destruídos, apresentada nesse material gráfico, suscita questionamentos sobre a relação dos traçados das rotas com as povoações quilombolas.

A estrada para Piracatù ${ }^{[j]}$ (em verde escuro) desviava seus curso, formando o desenho de um V em planta, para encontrar o quilombo $\mathrm{N}^{\mathrm{o}} 34$, que estava implantado em um vale em meio a serra da Marçela ${ }^{\left[{ }^{\mathrm{N} 22}\right]}$, próximo ao rio da Perdição ${ }^{[\mathrm{F} 12]}$. A estrada que vinha de Bamboŷ se fundia com a Picada de Goŷas junto ao quilombo No33.

É difícil estabelecer com precisão se os quilombos precederam as estradas ou o inverso. No entanto, um detalhe na rota da estrada de Pamplona nos permite especular algo.

A "Estrada que fes pessoalmente o Mestre de Campos para se conheçer estas vertentes no Sentro da Capitania" ${ }^{[0]}$, que atravessava a região entre as nascentes do rio de São Francisco ${ }^{[\mathrm{F} 00]}$, Pernaiba ${ }^{[\mathrm{P} 00]}$, e Santa $\mathrm{Fe}^{[\mathrm{S} 00]}$ (onde os poucos povoados portugueses 
contrastam com os muitos quilombos), segundo sua própria descrição, foi feita com o objetivo de conhecer a área ainda estranha para esses agentes do Estado português naquele momento. De acordo com esse documento, a execução dessa picada foi contemporânea à destruição dos quilombos. Porém, ambas as atividades foram realizadas no mesmo momento?

Os quilombos instalados nas imediações das estradas poderiam ter se implantado junto aos caminhos abertos por luso-americanos para atacar os mesmos. O comércio clandestino entre quilombolas e moradores luso-americanos nas suas imediações não pode ser descartado. É possível que os quilombolas fornecessem mantimentos para núcleos mineradores subordinados ao Estado português, que ficavam muitas léguas distantes.

Contudo, se os quilombos vinham depois de instaladas as estradas, por que a picada aberta por Pamplona iria em direção ao Ambrozio ${ }^{[43]}$, uma vez que esse quilombo tinha sido extinto a pelo menos uma década? É possível que alguns desse quilombos tenha sido apropriados pelos súditos portugueses para servir de base de apoio para as tropas bélicas e outros viajantes.

Buscamos explorar essas e outras questões, confrontaremos o "Mappa da Conquista do Mestre Pamplona [...]" com outros documentos produzidos no mesmo período que abordam a destruição de quilombos na zona do Campo Grande. Assim, no item seguinte, analisamos os relatórios da expedição empreendida anos antes pelo mesmo Mestre de Campos, cujos detalhados diários de jornada, mapa da região e desenho dos quilombos encontrados nos dão mais elementos para a investigação sobre as disputas travadas pela colonização dessa região. 
Documento M01 - Mappa da Conquista do Mestre de Campos Regente Chefe da Legião

Ignacio Correya Pamplona. [ca.1784]

EDIÇÃO DOS TEXTOS DO MAPA

[AA] Mappa da Conquista do Mestre de Campos Regente Chefe da Legião Ignacio Correya Pamplona

[AB] Fiel copia do Mappa que entreguei ao $\mathrm{Ill}^{\mathrm{mo}}$. Luiz da Cunha Menezes, que por elle foi Criado a Legião com 2// Regimentos de Cavallaria e Infantaria e 14//Esquadras do Matto tudo na Comquista do Campo grande, e suas anexas da Comarca do Rio das Mortes, no anno 1784// $\mathrm{N}^{\circ} 6$.

$<28><$ Monteiro $>$

[AC] [escala gráfica] 5 Legoas

$\mathrm{N}^{\mathrm{o}} 1$ Capela da Snr ${ }^{\mathrm{a}}$. da Oliveira.

No28 Serra dos Paulistas

No2 $\mathrm{V}^{\mathrm{a}}$. nova de Tamandoâ Matris de S.

No29 Serra dos Araras

Bento

No3 Capela de S. Francisco de Paulla

No4 Capela do Bom Suçeço detras da Serra da Iboturuna

No5 Capela de Santo Antonio do Amparo

No6 Capela do Sr. Bom Jezus dos Perdoens

No7 Capela de S. Anna

$\mathrm{N}^{\circ} 8$ Bom Jezus de Matozinhos

No9 Capela da Snr ${ }^{\mathrm{a}}$. das Candeyas.

$\mathrm{N}^{\circ} 10$ Capela de S. Vicente da Formiga

$\mathrm{N}^{\circ} 11$ Matris da $\mathrm{S}^{\mathrm{a}}$. do Livramento do Piuhî

No12 Capela de Santo Antonio da Serra da ponte de Diamante

$\mathrm{N}^{\circ} 13$ Capela de S. Francisco de Salis

No14 Capela da Snr ${ }^{\mathrm{a}}$. do Carmo do Japão

No15 Capela da Snr ${ }^{\mathrm{a}}$. do Desterro

$N^{\circ} 16$ Capela da Snr ${ }^{\mathrm{a}}$. da Apareçida do Clausio

$\mathrm{N}^{\circ} 17$ Capela do Espirito Santo e S. Francisco de Paulla

$\mathrm{N}^{\mathrm{o}} 18$ Capela do $\mathrm{S}^{\mathrm{r}}$. Bom Jezus dos Moraes

No19 Capela de S. Antonio do Monte de Diogo Lopes

$\left[\mathrm{N}^{\circ}\right] 20$ Matris de S. Anna de Bamboŷ

No21 Rio de S. Francisco

No22 Serra da Marçela

No23 Serra da Castra

No24 Fazenda da Palestina

No25 Serra de S. Pedro de Alcantara

No26 Serra do Piuhî

No27 Serra negra

No30 Quilombo destruido pelo Mestre de Campos na Mata da Tapada

No31 Quilombo destruido pelo Mestre de Campos Regente

No32 Quilombo destruido pelo Mestre de Campos Regente

$\mathrm{N}^{\circ} 33$ Quilombo destruido pellos Boinos

No34 Quilombo destruido pelos Boinos

No35 Quilombo do Andaŷa

No36 Quilombo que destruiu o Mestre de

Campos

No37 Quilombo destruido pelo Mestre de

Campos

No38 Quilombo destruido pelo Mestre de

Campos

№ 39 Quilombo destruido pelos Boinos

$\mathrm{N}^{\mathrm{o}} 40$ Destacamento dos Arrependidos

№41 Quilombo destruido no anno de 1764

No42 Quilombo destruido pelo Mestre de

Campos Regente

43 Quilombo do Ambrozio

No44 Arrayal do Piracatû

No45 São Marcos

No 46 Río de Sãa Marcos

$N^{\circ} 48$ Arrayal do Rio das Velhas

49 Dezemboque

$N^{0} 50$ Fazenda do Pedrozo, em terras da Capitania de Minas Geraes

$\mathrm{N}^{\circ} 51$ Cabeceiras do Rio Grande

No 52 Río Pernaiba Barra

$N^{o} 53$ Vertentes para o Rio de S. Francisco 
[a] Caminho que vem da Villa de São Josê

[b] Picada para Piuhî

[c] Picada de Goŷas

[d] Estrada que fes o Mestre de Campos Regente

[e] Estrada para o Río de S. Francisco

[f] Serra do Lourenço Castanho

[g] Estrada para S. Romão

[h] Mata da Corda, que dizem tem de comprido 27 Legoas

[i] Morro do Palhano

[j] Estrada para Piracatù

[k] Este Río da Palestina atravessa[?] da outra parte esta

Serra, e vem do Sentro estas vertentes

[1] Morro do Orubû

[m] Estrada para o Arrayal do Río das Velhas

[n] Serra da Canastra

[o] Estrada que fes pessoalmente o Mestre de Campos para se conheçer estas vertentes no Sentro da Capitania

[p] Serra de Santa Margarida de Cortona

[q] Aragoens

[F00] Rio de S. Francisco

[F01] Ribeirão de S. Antonio

[F02] Ribeirão do Esmiril

[F03] Ribeirão dos Cabrestos

[F04] Ribeirão das Araras

[F05] Ribeirão de S. Miguel

[F06] Ribeirão de S. Julião

[F07] Ribeirão do Arco

[F08] Ribeirão do Paraizo

[F09] Ribeirão de S. Ana

[F10] Ribeirão do Espirito Santo.

[F11] Ribeirão do Desterro

[F12] Rịo da Perdição

[F13] Río Jorge menor

[F14] Río Jorge do meyo.

[F15] Río Jorge mayor

[F16] Río Andaŷa

[F17] Río da Prata

[F18] Rio de S. Antonio

[F19] Rio do Sono

[F20] Río Abaitê

[F21] Barra do Río Parâ

[S00] Rio Santa Fê.

[S01] Ribeirão do Maronbom

[S02] Rio dos Carrapatos

[S03] Río de Santa Tereza

[S04] Río das Onze mil Virgens

[S05] Río de S. Elena

[S06] Río Salitre

[S07] Río Bem fica

[S08] Ribeirão de São Ignacio

[S09] Río Turvo

[S10] Rio de S. Hipolito
[Da] Destacamento das Marmeladas

[Db] Destacamento da Barra do Río Parâ

[Dc] Destacamento do barbas de bode, e mandado redificar pelo $\mathrm{Ex}^{\mathrm{mo}} . \mathrm{S}^{\mathrm{r}}$. Visconde

[Dd] Destacamento na Serra dos confins por ordem do $\mathrm{S}^{\mathrm{r}}$. Visconde de Barbaçena

[De] Destacamento posto pelo Exmo. $\mathrm{S}^{\mathrm{r}}$.

Visconde

[Ma] Marco pella Camara de Sãa Josê

$[\mathrm{Mb}]$ Marco que divide esta Capitania de Goyas

[Mc] Marco posto por esta Capitania

[Fa] Fazenda da Babilonia

[Fb] Fazenda da Gloria

[Fc] Fazenda dos Fomiros[?]

[Fd] Fazenda do Ribeirão das Almas

[Gg] Gentio

\section{[G00] Rịo Grande}

[G01] Río Jacarê

[G02] Rio da Formiga

[G03] Río Lambarî

[G04] Río do Piû̂

[G05] Aonde faz Barra o R ${ }^{\circ}$. Sapucahî

[G06] Río Turvo

[G07] Río da Murça

[G08] Río do Esmeril

[G09] Río Grande

[G10] Río da Forquilha

[G11] Rio das Bateyas

[G12] Río de S. Dionizio

[G13] Río das tres Barras

[G14] Río Claro

[G15] Rịo da Forquilha ou chamado do engano

[G16] Río de Santo Antonio

[G17] Río das Velhas

[G18] Ribeirão da Parida

[G19] Ribeirão Danta

[G20] Ribeirão do Rịo das Velhas

\section{[P00] Río Pernaiba}

[P01] Ribeirão dos Dourados

[P02] Río São Bento

[P03] Ribeirão de São Bento

[P04] Rio Batalha

[P05] Pisarão [?] 


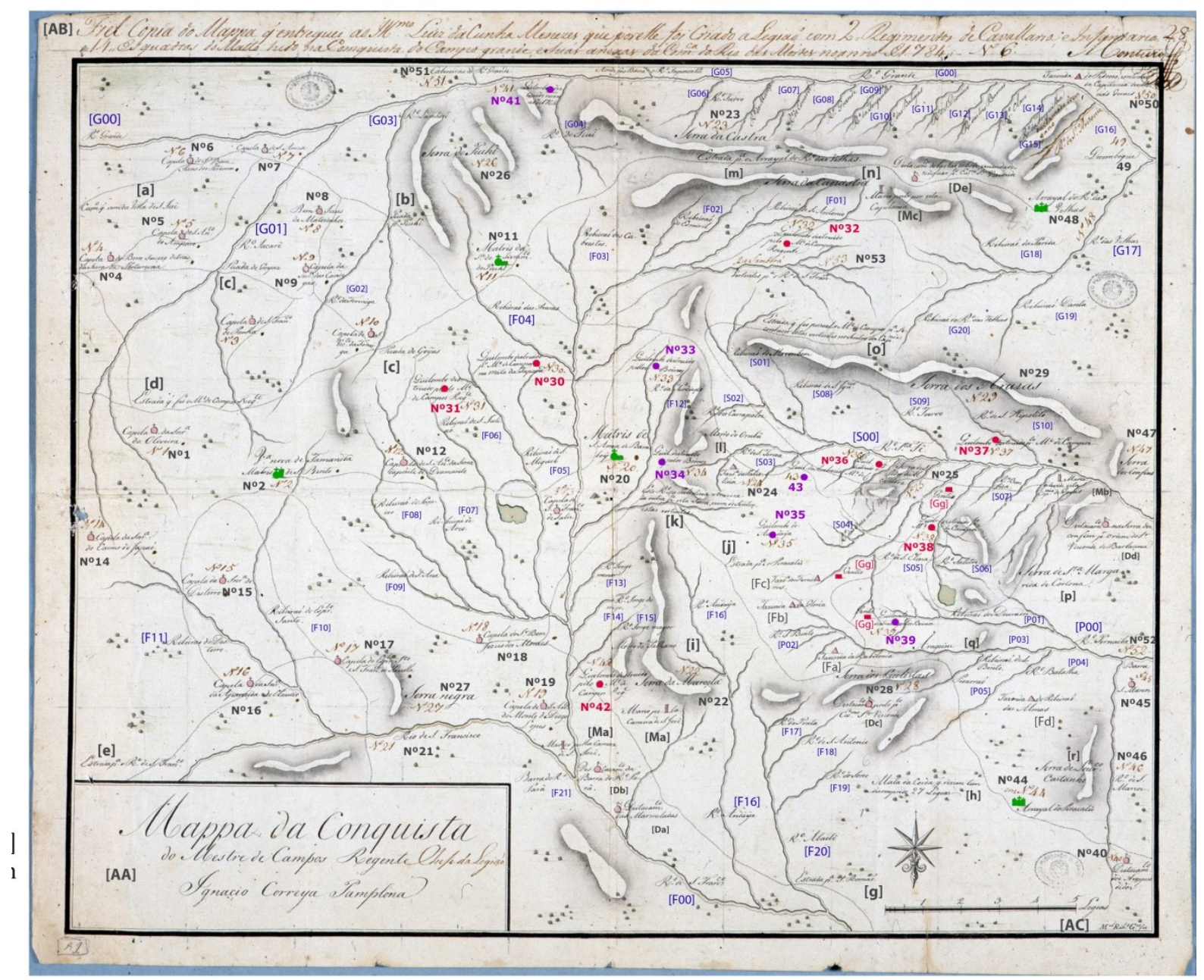

Mappa da Coquista do Mestre de Campos Regente Chefe da Legião Ignacio Correya

Pamplona [ca.1784]. Papel. 1 mapa, 32,4x39,9cm. Projeto Resgate - Arquivo Histórico Ultramarino . código: AHU_CARTm_011, D.1165 . 


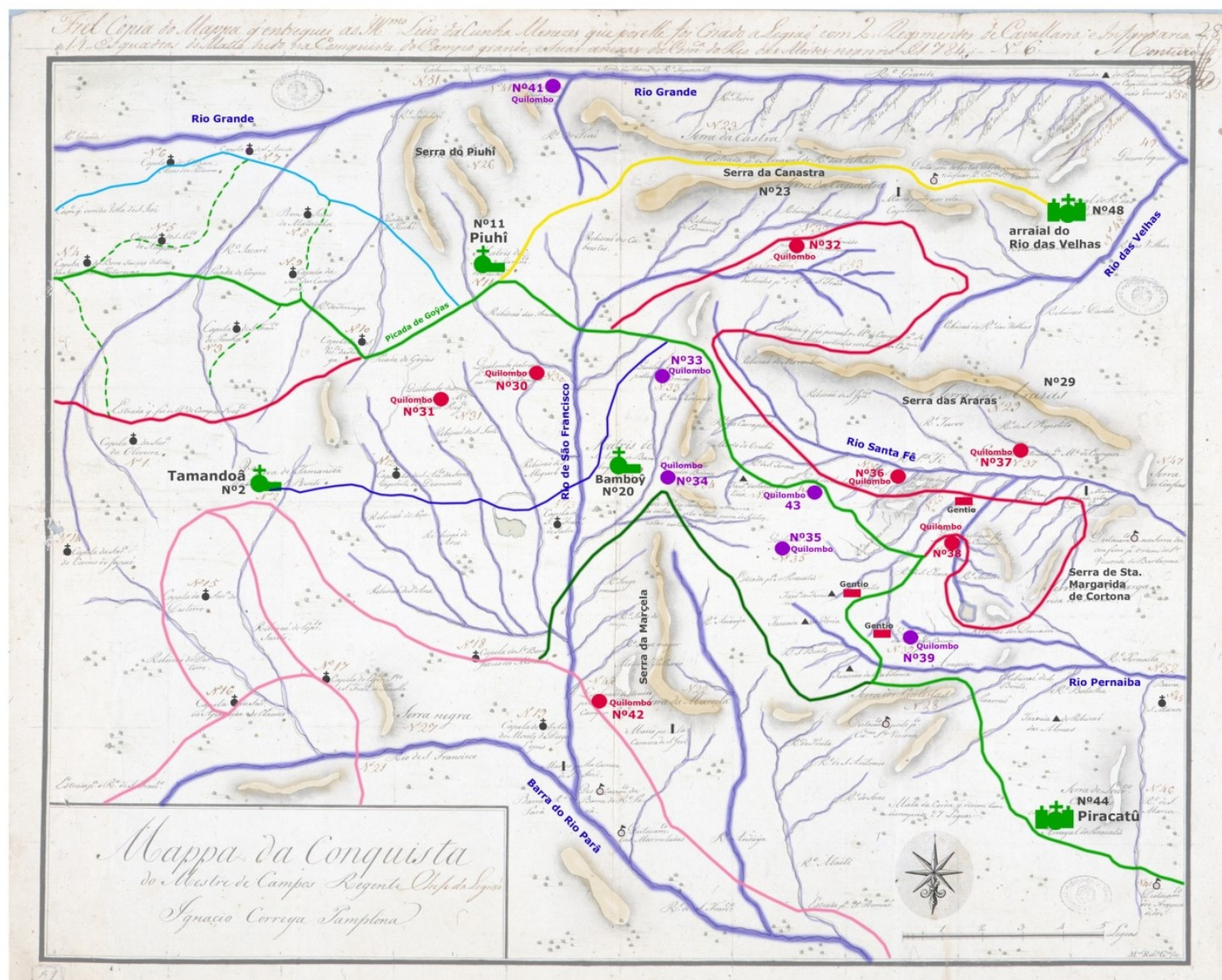

Estradas e povoados no "Mappa da Coquista do Mestre de Campos Regente Chefe da Legião Ignacio Correya Pamplona"

Caminho que vem da Villa de São Josê [a] e Picada para Piuhî [b] (em ciano) Picada de Goŷas [c] (em verde claro) Estrada que fes o Mestre de Campos Regente [d, o] (em vermelho) Estrada para o Arrayal do Rio das Velhas [m] (em amarelo)

Estrada para o Rio de S. Francisco [e] e Estrada para S. Romão [g] (em rosa) [caminho entre villa de Tamandoâ $\left(\mathrm{N}^{\circ} 2\right)$, matriz de Bamboŷ $\left(\mathrm{N}^{\circ} 20\right)$ e quilombo $\mathrm{N}^{\circ} 33$ ] (em azul escuro) Estrada para Piracatù [j] (em verde escuro) 


\section{2 - RELATÓRIOS DA EXPEDIÇÃO DE IGNACIO CORREYA PAMPLONA DE 1769}

Os relatórios da jornada da conquista dos sertões para além da serra da Marçella, comandada pelo Mestre de Campo, Regente e Guarda-Mor Ignacio Correya Pamplona (empreendida entre agosto e novembro de 1769), são constituídos por duas narrativas textuais, por desenhos de seis implantações de quilombos e do "lugar do Salitre" e por um mapa com o trajeto da expedição. ${ }^{21}$

Tais documentos encontram-se atualmente sob guarda da Biblioteca Nacional no Rio de Janeiro, reunidos em um códice ${ }^{22}$ que integra o arquivo Conde de Valadares, que reúne documentos da gestão de José Luís de Meneses Castelo Branco e Abranches, sexto conde de Valadares, que foi governador de Minas Gerais entre os anos de 1768 a 1773.

Devido à restrição de acesso aos originais, para análise dos documentos textuais utilizo aqui sua versão publicada na revista da Biblioteca Nacional ${ }^{23}$. Já para a análise das imagens dos relatórios, utilizamos os documentos originais e suas reproduções fotográficas capturadas pessoalmente. Na edição paleográfica dos textos que aparecem nos documentos iconográficos preservamos a grafia original dos os nomes próprios de rios, serras, quilombos, arraiais e outros conforme aparecem no documento, havendo divergências de ortografia entre esses documentos com outras fontes analisadas.

Para facilitar o cruzamento das informações trazidas pelos relatos textuais com os desenhos do documento, na análise incluímos a referência de legenda do mapa editado entre colchetes.

Adiante nos detemos na analise de tais relatórios da expedição de 1769 buscando, a partir dos dados apresentados nesses documentos, entender as características materiais dos quilombos encontrados pelas tropas, os interesses e as estratégias de conquista territorial dos expedicionários luso-americanos relacionados aos quilombos destruídos, entre outros.

\footnotetext{
${ }^{21}$ Biblioteca Nacional do Rio de Janeiro, seção de manuscritos, Coleção Ottoni, arquivo conde de Valadares, código: MS-575 (1).

${ }^{22}$ Códice é uma coleção de documentos manuscritos reunidos em uma encadernação.

${ }^{23}$ [Encontrando Quilombos]. Transcrição e edição por Maria Filgueiras Gonçalves. Anais da Biblioteca Nacional, Rio de Janeiro, v.108, p.47-113, 1988. (Adiante citado como ANBRJ, 1988)
} 


\subsection{1 - A jornada de conquista do sertão do Campo Grande de 1769 segundo seus relatórios}

No inverno de 1769, partiu dos arredores da vila de São João ${ }^{[1]}$ uma expedição bélica cujo propósito era conquistar parte do sertão do Campo Grande, na margem oeste das cabeceiras do Rio de São Francisco, tomando posse da região em nome do governador da capitania de Minas Gerais. Entre os objetivos expressos da campanha estavam a identificação de novas jazidas de ouro, a destruição de quilombos e a facilitação do povoamento daquela região.

Avançando entre 2,5 e 8 léguas ${ }^{24}$ por dia de marcha, a tropa saiu em meados de agosto das proximidades do rio de Santo Antônio ${ }^{[a]}$, afluente do Rio Grande ${ }^{[34]}$, atravessou o rio de São Francisco ${ }^{[\mathrm{k}]}$ e a serra da Marçella ${ }^{[\mathrm{rr}]}$, seguindo sertão adentro até pouco além da paragem do salitre ${ }^{[\mathrm{xx}]}$, dali retornando para o ponto de partida, encerrando a jornada no fim de novembro do mesmo ano de 1769.

Saíram inicialmente com 52 bestas de carga com comestíveis, bebidas e botica, alguns cavaleiros, 58 escravizados "com armas de espingarda, clavinas, facões, patrona, pólvora, chumbo e bala", dois "pretos tambores, com suas caixas cobertas de encerado", oito músicos (sete dos quais também eram escravizados) com "violas, rebecas, trompas e flautas travessas", juntamente com seu proprietário e líder da expedição, Ignacio Correya Pamplona, que acumulava os títulos de Mestre de Campo, Regente e Guarda-Mor "de todas as picadas de Goiases, Bamboí e Piui'. Durante o percurso, se juntaram às tropas um reverendo capelão, um "surigião", soldados pagos, homens recrutados e outros.

Acompanharam a jornada ao menos dois diferentes cronistas: um autor da "Notícia diária e individual das marchas" 25 que apresentou os "sucessos de cada dia" da campanha de

\footnotetext{
${ }^{24}$ Légua é uma medida de comprimento empregada na cartografia que se reporta ao corpo humano e tem como referência astronômica uma fração do arco de meridiano terrestre de um grau. $\mathrm{Na}$ cartografia da América portuguesa a légua correspondia a 3.000 braças, que equivalem a 6.522 metros, dimensões que eram representadas com exatidão dependendo dos instrumentos e técnicas de medição disponíveis. Tomada por aproximação, uma légua corresponde a uma hora de caminhada a passo cheio. Ver: BUENO, Beatriz P. S. Desenhando o Brasil: o saber cartográfico dos cosmógrafos e engenheiros militares da Colônia e do Império. In: COSTA, Antônio Gilberto. Roteiro prático de cartografia: da América portuguesa ao Brasil Império. Belo Horizonte: ed. UFMG, 2007. p.29-49; SANTOS, Márcia Maria Duarte dos. Técnicas e elementos da cartografia da América portuguesa e do Brasil Império. In: COSTA, 2007, p.51-81.

${ }^{25}$ ANBNRJ, 1988, p.53-96
} 
conquista do sertão; outro, responsável pelo mapa com trajeto da expedição e seus arredores (ver mapa editado M02) ${ }^{26}$, pelos desenhos de implantação dos quilombos por onde passaram (documentos G01-G06) e do lugar do Salitre, assim como pelo respectivo relatório associado às ilustrações ${ }^{27}$, que nesta análise batizamos de "Memorial dos Mapas".

A rotina da comitiva foi destacada em seu diário: ao romper da aurora, eram tocadas as caixas da alvorada, os músicos executavam seus minuetos, era celebrada a missa, servido almoço e então as tropas se dedicavam aos serviços do dia. Para abrir caminho para a expedição, escravizados com foices, machados e enxadas rompiam os matos, faziam pontes nos córregos e ribeirões, construíam ranchos para descanso de tropas ${ }^{28}$. Durante o trajeto, o Mestre de Campo nomeou diversos capões do mato, cursos d'água e serras ainda não batizados por representantes da coroa portuguesa. Ao longo do percurso, alguns "magnatas do País" vieram ao encontro do Regente, lhe ofertando poemas, solicitando terras e apaziguamento de contendas. Nos povoados por onde passou, Pamplona prendeu e emitiu ordens de prisão para algumas pessoas, enquanto o reverendo capelão batizava crianças e tomava confissões.

Transcorridas apenas cinco léguas para além da capela de Nossa Senhora da Oliveira, o relator diz não achar mais "gente de qualidade algũa, mais que um pobre velho" em um sítio composto de duas casas velhas de capim, ameaçadas de ruína. Chegando ao povoado de Piuhÿ ${ }^{[66]}$, o Mestre se "enfadou contra a gente tão bárbara e endômita, que abusavam de Deus, e de seus santos, por não conservarem um templo", ordenando a construção de uma igreja. $^{29}$

Seguindo em direção ao rio de São Francisco ${ }^{[\mathrm{k}]}$, chegaram às suas margens no Porto velho $^{[67]}$ fazendo a travessia das gentes por canoas, enquanto os animais foram a nado, levando seis dias para passar todo o "trem". A expedição dedicou aproximadamente um mês de trabalho para construção de ponte em madeira sobre tal rio ${ }^{[68]}$. Para a inauguração, foi feita uma procissão solene, com marcha sobre a ponte, celebração de missa na capela de São Francisco de Sales e Santa Maria (que também construíram), seguida de um "banquete onde se contavam 65 homens brancos" que declamaram poemas e fizeram requerimentos de

\footnotetext{
${ }^{26}$ [Mapa do trajeto da expedição de 1769 de Ignacio Correya Pamplona]. [1769?]. Papel. 1 mapa. Manuscrito. Português. Arquivo BNRJ, Coleção Ottoni, código: MS-575 (1), folha 245. A imagem apresentada é uma edição da reprodução fotográfica do documento original.

${ }^{27}$ ANBNRJ, 1988, p.96-113

${ }^{28}$ ANBNRJ, 1988, p.57-60 e 67

${ }^{29}$ ANBNRJ, 1988, p.57-58
} 
sesmarias. Pamplona os questionou se eles tinham condições de "fabricarem as ditas 3 léguas de terras". Em resposta, tais requerentes "Ihe deziam um tinha oito Negros, outro dez, e outro doze". A construção da ponte foi destacada por um dos cronistas como um "serviço tão útil à real Coroa como necessário ao bem comum e aos novos entrantes, cujos já passaram de duzentos, a qual entrada lhe facilitou a dita ponte de tal sorte que em breves tempos, se verá aquele País coltivado de Abondantes povos de que o Irário Real receberá grande otilidade". 30

Seguiram, então, para o arraial de Nossa Senhora Santa Ana de Bambohÿ ${ }^{[70]}$, na margem oeste do rio de São Francisco, onde Pamplona mandou erguer a nova capela-mor da freguesia. Dali o Mestre de Campo despachou duas bandeiras para a outra parte da serra da Marçella, uma comandada por José Serra e outra por José Cardoso, partindo no início de setembro. Esses destacamentos retornaram cerca de um mês depois, um não tendo achado o ouro procurado, enquanto o outro encontrou dois quilombos próximos ao rio da Perdição ${ }^{[\mathrm{q}]}$, apresentando "notícia dos Negros, que tinham morto, dos que tinham fugido e de um que trouxeram amarrado". 31

Para a travessia da serra da Marçella ${ }^{[\mathrm{rr}]}$, todas tropas foram reunidas na fazenda de Pamplona ${ }^{[69]}$, nos arrabaldes de Bambohÿ ${ }^{[70]}$, onde preparam as armas, distribuíram pólvora, chumbo e bala para prevenção dos viajantes. A campanha partiu em meados de outubro com 96 pessoas (sendo 42 cavaleiros e 54 pedestres), 42 bestas de carga e 2 cavalos adestra. ${ }^{32}$

No segundo dia de jornada para além da serra da Marçella ${ }^{[\mathrm{rr}]}$ a expedição chegou às ruínas do Ambrozio ${ }^{[74]}$, "quilombo não afamado nestas minas como prejudicial aos moradores delas", onde admiraram "os arruinados idificios e multiplicados fojos, todos crivados de estrepes". Implantado em área de restinga de capoeira, o extinto povoado ficava junto a um córrego, onde as tropas aquartelaram por sete dias, quando metade das gentes foi examinar os córregos e ribeirões vizinhos à procura de mostras de ouro, enquanto a outra parte se dedicou ao cultivo, passando fogo na terra para plantar feijão, algodão e seis alqueires de milho. ${ }^{33}$

Finalizados os trabalhos no Ambrozio, foram a cavalo até a paragem do Sambabaÿa ${ }^{[76]}$, "onde tinha um quilombo de Negros e ali plantamos ũa Roça de milho, feijão

\footnotetext{
${ }^{30}$ ANBNRJ, 1988, p.61-64/ p.100

${ }^{31}$ ANBNRJ, 1988, p.58/ p.64/ p.100

${ }^{32}$ ANBNRJ, 1988, p. $67 /$ p. 100

${ }^{33}$ ANBNRJ, 1988, p.67-70 / p.101
} 
e algudão". Ainda no mesmo dia seguiram para o rio das Honze mil virgens ${ }^{[81]}$. Novamente buscaram ouro nos veios d'água das imediações, sem resultados. Ali, Pamplona destinou a área entre o córrego do Sacramento ${ }^{[77]}$, o córrego do Bom Jesus ${ }^{[75]}$ e a serra de São Pedro de Alcantra $^{[78]}$ até o quilombo do Ambrozio ${ }^{[74]}$ (polígono que abrange o quilombo da Sambabaÿa ${ }^{[76]}$ ) para constituição de sua própria fazenda e para patrimônio de Nossa Senhora da Conceição, determinando o sítio para fundação de um novo arraial. ${ }^{34}$

O temor de integrantes das tropas acerca dos quilombolas se destacou na narrativa desde a marcha para a serra da Marçella, engrossando os murmúrios e o receio à medida que adentravam aquela região. Seguindo viagem pela serra das Mangabas ${ }^{[\mathrm{tt}]}$ e de São Rafael ${ }^{[\mathrm{vv}]}$, avistaram "grandes fomaças",[85/87], "julgando os mais Tapijaras ${ }^{35}$ do Sertão, que eram muntos negros que se avezinhavam à nossa Cometiva, reciaram o ir a explorá-los e reconhecê-los por mais que o Senhor Mestre de Campo a isso os persuadia, sempre lhe replicaram com apresentação de um grande perigo e que os quilombos eram muntos para aquela parte segundo os sinais dos mesmos fogos e que era pública mente notório que havia para ali quilombo que se compunha de mais de duzentos negros". ${ }^{36}$

Para ir reconhecer as áreas que "estariam com efeito infestadas de Negros", Pamplona mandou buscar toda bagagem e tropas para engrossarem "o número da gente e das armas". Sob comando de José Cardoso, foram enviadas 42 pessoas com pólvora, chumbo e balas e mais armas curtas, para examinar os locais onde os quilombolas podiam estar refugiados, e achando vestígios deveriam mandar avisar para socorrê-los. Tal bandeira marchou dois dias inteiros, "rompendo matos e Serras fragosas", sem achar os povoados quilombolas. Os fogos indicavam estarem por perto, "porém que estes estariam mais amarados ao Sertão". No entanto, como não tinham quem os guiasse "à paragem e habitação dos mesmos Negros", toda a diligência era frustrada e perigosa. ${ }^{37}$

Continuando com a marcha pelo alto do chapadão da serra de São Rafael ${ }^{[\mathrm{vv}]}$, avistaram o lugar do quilombo de Sam Gonçalo ${ }^{[79]}$, em meio a área de Campina ${ }^{[\mathrm{r}]}$. Uma das bandeiras, comandada pelo Tenente José da Serra Caldeira, foi até o local, onde prendeu um quilombola

\footnotetext{
${ }^{34}$ ANBNRJ, 1988, p.70-71/ p.101

${ }^{35}$ Tapijara é termo derivado do tupi que designa o prático que conhece certa região e seus caminhos.

${ }^{36}$ ANBNRJ, 1988, p.68/ p.71

${ }^{37}$ ANBNRJ, 1988, p.71-72
} 
que estava fazendo farinha, tendo os demais fugidos. A tropa confiscou a farinha "junto com vários trastes e panos de Algudões feitos ricamente pelos mesmos Negros ", 38

O restante das tropas seguiu caminho até o pé da serra e, se afastando da picada velha de Goiás cerca de uma légua e meia, o Mestre de Campo e mais 40 pessoas, "todos a pé mas bem armados, foram penetrando uns Capões de Matos por serras altivas, ásperas e fragosas, encaminhando-se ao lugar de um quilombo, chamado Corisco, e mandando ir toda a mais gente e bagagem mais dilatada e vagarosa por diferente rumo ao mesmo lugar." Chegaram a "a ele prevenidos de toda a precisa cautela, porém foi baldada esta deligência, porque os Negros talvez tendo nos avistado por meio de Suas espias, desertaram”. Próximo ao córrego de águas abundantes, o local foi intitulado "Santos fortes". Ali uma parte dos homens foi procurar metais preciosos nos córregos, só achando algum esmeril, enquanto outra plantou três alqueires de milho, e também feijão, abóboras, mamona, mandioca e favas. ${ }^{39}$

A campanha continuou a viagem margeando serra de São Rafael ${ }^{[v v]}$ chegando, no dia 01 de novembro, ao ribeirão do Salitre, “aonde esteve já muntos anos e há poucos se tornou a retificar um quilombo chamado o Catiguá ${ }^{[91]}$, [...] e agora de próximo se retiraram temoratos das nossas Bandeiras, aqui colhemos algum milho que era o resto que eles tinham deixado e nos serviu para dar a algum cavalo mais frouxo." Sobre as terras desse quilombo as tropas armaram "um Arraial de casas de capim mui bem airoso, porque a paragem é de Si mesmo mui vistosa e agradável." Ali "apanharam bastantes caças de viados, perdizes, e Jacuses" e no rio pescaram "com pouco espaço treze peixes, com o nome de Tobaranas de munto boa grandeza". Nessa região perceberam algum sinal de ouro, porém em quantidade insatisfatória: "em cada bateada eram ũa faisquinha, duas até três, mas mui finas". 40

A comitiva partiu a cavalo examinando os arredores para estabelecer o novo arraial de Santa Maria de Cortona do Salitre ${ }^{[93]}$ naquelas partes e "fazer nele ato de posse". Para ato da fundação foram ao alto da serra, tocaram as caixas para juntar a gente toda, fizeram cruzes com pau de sucupira do campo onde colocaram imagens religiosas, rezaram, tocaram trompas, flautas, violas, rebecas e cantaram. O Mestre de Campo, então, pronunciou que "tinha vindo por mandado do Ilustríssimo e Excelentíssimo Senhor Conde Valadares, Governador e Capitão General desta Capitania de minas gerais, para repartir aquelas terras a quem lhas pedir" e, uma vez deferidos os requerimentos por sesmarias, deviam cuidar "em

\footnotetext{
${ }^{38}$ ANBNRJ, 1988, p.101-102

${ }^{39}$ ANBNRJ, 1988, p.72-73

${ }^{40}$ ANBNRJ, 1988, p.75-76
} 
povoar o que tinham pedido", uma vez que o General "não queria as terras devolutas". Pamplona encerrou ali a exploração do território pois "não podia avançar mais Sertão, sem que primeiro se pavoasse aquele para que os que fossem ficando mais distantes tivessem nos daquele lugar sacorro de mantimentos". 41

Os expedicionários voltaram para o quilombo do Catigal ${ }^{[91]}$, para ir até uma paragem "misteriosa", distante pouco mais de uma légua, abrindo caminho por entre os matos "ásporo e terrivel" com foices, machados e enxadas, para entrar os cavaleiros junto com o Mestre ao Salitre ${ }^{[92]}$. O local tinha cheiro semelhante à pólvora, era cercado por árvores frondosas, com muitos pássaros e animais. Corriam ali duas fontes de águas claras, escorregadias como sabão, com cheiro de pólvora e que travava na língua. Os cavalos beberam, ficando "bem purgados", e dois escravizados pelo Mestre sararam suas feridas com essas águas. Novas experiências de ouro foram feitas, sem resultados. ${ }^{42}$

O regresso da expedição para os arredores de São João ${ }^{[1]}$, de onde tinham saído há meses, foi marcado pelo retorno aos quilombos por onde passaram na ida, agora transmutados em pousos para as tropas. Saindo no início de novembro do Catigal ${ }^{[91]}$, onde armaram rancho, passaram pelo quilombo dos Santos Fortes ${ }^{[90]}$, onde tinham ficado "um pardo e dous pretos" cuidando de um animal doente. Esses disseram que "os Negros calhambolas os tinham andado espiando de noute". Ali avistaram fumaças no interior, que julgaram serem quilombolas "pois como no Sertão não mora mais ninguém, é infalível consequência que os fogos haviam ser dos mesmos Negros". Dois dias depois chegaram novamente ao quilombo do Ambrozio ${ }^{[74]}$, onde viram "nascido e bonito" o milho que as tropas plantaram anteriormente. Mais dois dias de marcha e chegaram ao pé da serra da Marçella ${ }^{[\mathrm{rr}]}$, onde tocaram as caixas para reunir a gente. Então Pamplona se despediu do lugar, lembrando de irem povoar suas fazendas e afirmando que a "terra do Sertão era mui fértil, abundante e saudável", com pastos de boa qualidade para criação de gado. ${ }^{43}$

Com salva de 300 tiros e toque dos instrumentos, depois de 102 dias de jornada, a expedição foi encerrada na primavera de 1769 na mesma fazenda onde iniciaram o percurso, localizada entre o arraial e capela de Senhora da Oliveira ${ }^{[41]}$ e as vilas de São João ${ }^{[1]}$ e São José $^{[2]}$. O relato da "Notícia Diária" foi finalizado com a lista de novos entrantes e pedidos de sesmarias nos arraiais de Santa Anna de Bambohÿ, de Nossa Senhora da Conceição da

\footnotetext{
${ }^{41}$ ANBNRJ, 1988, p.77-78

${ }^{42}$ ANBNRJ, 1988, p.75, p.78 e p.79

${ }^{43}$ ANBNRJ, 1988, p.79-81
} 
Conquista do Campo Grande, no ribeirão das Araras, Andaia, até rio do Picão e na Nossa Senhora do Livramento do Piuhÿ. ${ }^{44}$

Não tendo encontrado ouro em volume satisfatório, a utilidade pública dessa expedição foi reafirmada em seus relatórios através do destaque aos seus feitos, como: a promoção da igreja católica por meio da realização de batismos, edificação de templos em Piuhÿ ${ }^{[66]}$ e Bambohÿ ${ }^{[70] ;}$ a aplicação da justiça através de prisões e arbitragem de conflitos; a abertura de estrada de 49 léguas de comprimento desde o pouso alegre ${ }^{[51]}$ até o Salitre $^{[92]}$, com construção da ponte sobre o rio de São Francisco ${ }^{[68]}$ (que apresentava vantagem em relação ao caminho velho por ser livre dos pântanos e travessias em canoas, tornando assim "mais suave a entrada dos que quisessem povoar aqueles sertões"); a concessão de sesmarias em terras férteis com campos para criação de gado na mesma região por onde se abriu passagem; a contribuição para a extinção dos quilombos do campo Grande, "tão projodiciais, e tão nucivos"; a demarcação de dois novos arraiais na região além da serra da Marçella ${ }^{[\mathrm{rr}]}$ : o da Senhora da Conceição e o de Santa Maria de Cortona do Salitre ${ }^{45}$. Esse conjunto de iniciativas tinha a finalidade declarada de "dilatar o domínio americano" da coroa portuguesa ${ }^{46}$.

\subsection{2 - Estrada de Pamplona e picada velha de Goiás no “Memorial dos Mapas “ de 1769}

Entre os documentos da expedição de 1769 de Pamplona, há um relato escrito que está associados às ilustrações dos locais explorados (mapa da região percorrida, implantações dos quilombos e da área do salitre) que, nesta análise, chamamos de "Memorial dos mapas" 47 . A seguir destacamos algumas das observações extraídas desse relatório que explicitam detalhes dos desenhos.

O memorial dos mapas principia com a descrição geral do caminho novo construído pela expedição: "Para se poder povoar esta terra, se fez ũa estrada de 49 léguas de comprido, que pega no pouso alegre e corre o rumo de precatu até o Salitre. Primeiramente depois de doze léguas de estrada, tem ũa capela com a vocação de São Francisco e Santa Maria, e ũa ponte no Rio de São Francisco ${ }^{[68]}$ ". No relato, foram identificadas as povoações inauguradas pelo Regente: logo depois da travessia do rio de São Francisco foi feita a matriz

\footnotetext{
${ }^{44}$ ANBNRJ, 1988, p.90-96

${ }^{45}$ ANBNRJ, 1988, p.53-112

${ }^{46}$ ANBNRJ, 1988, p.87

${ }^{47}$ ANBNRJ, 1988, p.96-103
} 
do novo arraial de Santa Anna de Bambohÿ ${ }^{[70]}$ e, para além da Serra da Marçella ${ }^{[\mathrm{rr}]}$, foram demarcados o arraial da Senhora da Conceição e o arraial de Santa Maria de Cortona do Salitre $^{[93]}{ }^{48}$

Ainda na abertura do texto, o memorialista diz que foi executando o "um Mapa de todo o País que fosse avançando na viagem em que Eu o acompanhei ao Campo Grande" destinado ao governador da capitania de Minas Gerais em exercício, o conde de Valadares, em cumprimento de ordem de Pamplona. Neste memorial, foi justificado que para maior precisão do mapa, eram necessárias melhores informações e medições geométricas dessas terras do que as que teve disponíveis. Sobre a escala usada, ele explica que foi adotada a proporção de 1 petipé $^{49}$ por légua de terreno. O próprio desenhista utilizou "algarismos" para referência das paragens, rios, serras, matos, cerrados e campos por onde estiveram, incluindo as legendas desses nas margens do mapa ${ }^{50}$.

O memorialista descreve o trajeto da picada velha para Goiás feita por Urbano Couto, que corria de "Su sueste para És noroeste" com início na ponte do Carandai ${ }^{[5]}$. Trechos desse caminho velho foram percorridos pela expedição de Pamplona: no início da jornada desde o morro Quebra Cangalhas ${ }^{[30]}$, passando pelo ribeirão de Santa Anna ${ }^{[46]}$ até o pouso alegre ${ }^{[48]}$; depois de passado o rio de São Francisco, rumo à serra da Marçella (letra A), novamente a tropa se aproximou da estrada na serra das Mangabas ${ }^{[\mathrm{tt}]}$ (letra B), na subida da serra de São Rafael $^{[\mathrm{vv}]}$ pelo chapadão até próximo ao Salitre (letra $\mathrm{C}$ ), e desse ponto em diante não tinham mais notícia do caminho velho.

De acordo com esse narrador, a estrada nova que o Mestre de Campo mandou abrir desde o Morro Cavado ${ }^{[i i]}$, atravessando rio de São Francisco ${ }^{[68]}$ sobre a ponte nova, daí para a Matriz de Santa Anna de Bambohÿ ${ }^{[70]}$ até acima da serra da Marçella ${ }^{[\mathrm{rr}]}$ (letra A), apresentava vantagem em relação ao caminho velho por ser livre dos cerrados, pântanos e travessias em canoas. $^{51}$

\footnotetext{
${ }^{48}$ ANBNRJ, 1988, p.96

49 "Petipê" ou "petipé" é um tipo de escala gráfica usada na época. A medida adotada podia ser gravada em régua de latão ou madeira para servir de instrumento para levantamento em campo e, depois, para transposição dessas medidas para os mapas. Ver: BUENO, op. cit., p.38-40.

${ }^{50}$ Para facilitar a visualização, em nossa edição do mapa esses números do manuscrito foram transcritos em azul, enquanto as letras em vermelho entre colchetes se referem à legenda que incluímos para transcrição dos textos no corpo do documento.

${ }^{51}$ ANBNRJ, 1988, p.96-97.
} 
No "Memorial dos mapas" descreve o trajeto da expedição (reforçado em vermelho no mapa editado M02), que teve início na capela de Nossa Senhora da Penha de França da Laje $^{[12]}$, passando pela cabeceira do rio Jacaré ${ }^{[31]}$, pela capela de Nossa Senhora da Oliveira $^{[41]}$, pela ponte natural em pedra no ribeirão do pouso alegre ${ }^{[48]}$ e daí adiante até o "Lugar de posse" ${ }^{\text {[93] }}$ próximo ao Salitre ${ }^{[92]}$. O memorialista diz que desde a fazenda Cachoeira ${ }^{[44]}$ até o rio Grande ${ }^{[34]}$ estava tudo povoado, e na mata da outra parte do rio Jacaré ${ }^{[b]}$ estava também quase tudo povoado. ${ }^{52}$

As tropas seguiram dali para fundar o arraial de Nossa Senhora Santa Anna de Bambohÿ, onde Pamplona mandou fazer uma capela-mor da freguesia, e depois retornaram para sua fazenda de São Simão, para o Mestre e Capitão-mor "pessoalmente ir ver indagar e repartir as terras que estão de outra parte da Serra da Marcela, de que já tinha algumas noticias que os Comandantes das Bandeiras se lhe tinham trazido". ${ }^{53}$

A expedição, então, adentrou as terras para além da serra da Marçella. Perto das ruínas do quilombo do Ambrozio, há identificação do local onde as tropas aquartelaram, em uma restinga de Capoeiras (letra F). Do alto do espigão da Serra de São Rafael, observaram as dilatadas campinas para norte e para sul, onde poderiam formar grandiosas fazendas. Passaram o rio de Santa Maria de Cortona ${ }^{[95]}$, ao qual se juntava um córrego que vinha da parte do Salitre. Mais adiante, "tomou posse o dito Senhor Mestre de Campo de tudo o quanto tinha avançado té a Serra ${ }^{[94]}$,", encerrando ali o avanço das tropas. ${ }^{54}$

\subsection{3 - Considerações sobre o Diário, Memorial e Mapa do Trajeto da Expedição de 1769}

A "Notícia diária" da jornada comandada por Pamplona traz como objetivos da expedição de 1769 a busca de ouro e a viabilização do povoamento na região próxima às nascentes do rio de São Francisco. Já no início do percurso, a um dia de marcha da capela de Nossa Senhora da Oliveira ${ }^{[41]}$, essa região foi descrita como pouco povoada ${ }^{55}$. Nesse documento, o limite do sertão foi colocado na serra da Marçella ${ }^{[\mathrm{rr}]}$, fronteira que para ser ultrapassada pela campanha exigiu todo um dia para preparação de $\operatorname{armas}^{56}$. Esses cuidados

\footnotetext{
${ }^{52}$ ANBNRJ, 1988, p.97-99.

${ }^{53}$ ANBNRJ, 1988, p.100.

${ }^{54}$ ANBNRJ, 1988, p.99-103.

${ }^{55}$ ANBNRJ, 1988, p.57.

${ }^{56}$ ANBNRJ, 1988, p.67.
} 
foram tomados por receio dos "negros" que moravam naquelas paragens ${ }^{57}$, sendo usados tais aparatos de guerra para destruir os quilombos que a expedição alcançasse. Os territórios quilombolas próximos ao caminho que estavam abrindo foram usados pelas tropas como ranchos para descanso e para plantio de alimentos para os novos entrantes.

A “Notícia diária" destacou o papel de Pamplona como Regente da região para onde foram dilatados os domínios americanos da majestade portuguesa sobre terras já ocupadas por quilombolas, mas vistas como incultas e desertas pelos reinóis ${ }^{58}$. Como saldo geral apresentado na "Notícia diária", compreendemos que a busca por novas minas auríferas foi frustrada, mas a utilidade pública da expedição foi reafirmada através de seus feitos ao construir igrejas, pontes e caminhos pelo sertão, ao conceder terras em nome da coroa para colonos apropriados, ao proteger os súditos portugueses da ameaça de "negros rebeldes", dedicando suas diligências à extinção dos quilombos do Campo Grande, como defende o expedicionário. ${ }^{59}$

No "Memorial dos mapas" a busca de ouro não tem destaque. A ênfase desse relato está na abertura de estradas para facilitação da povoação dos súditos portugueses sobre as terras desbravadas pela expedição e na demarcação de arraiais como pontos de apoio para essa colonização.

As terras dos quilombos surgem nos relatos da campanha de 1769 como locais apropriados para arranchar as tropas, fazendo plantio para futuros viajantes ${ }^{60}$ e, também, como sítios interessantes para estabelecimento de arraiais e fazendas: um dos locais escolhidos pelo Mestre de Campo para sua fazenda ficava sobre o Ambrozio, enquanto, dois dos três arraiais demarcados por Pamplona ficavam em terras subtraídas dos quilombolas que combateram.

\footnotetext{
${ }^{57}$ ANBNRJ, 1988, p.68, p.71-72.

${ }^{58}$ ANBNRJ, 1988, p.83, p.87.

${ }^{59}$ ANBNRJ, 1988, p.53-96.

${ }^{60} \mathrm{O}$ cultivo de alimentos por expedições pioneiras para abastecimento de tropas subsequentes era uma prática entre os exploradores paulistas. Ver: FONSECA, Cláudia Damasceno. Arraiais e vilas d'el rei: espaço e poder nas Minas setecentistas. Trad. de Maria Juliana G. Teixeira. Belo Horizonte: Ed. UFMG, 2011. p.61.
} 
Documento M2 - [Mapa da expedição de 1769 de Ignacio Correya Pamplona]. [1769?]. Papel. 1 mapa. Manuscrito. Português. Arquivo BNRJ, Coleção Ottoni, código: MS-575 (1), folha 245.

EDIÇÃO DE TEXTOS DAS LEGENDAS DAS MARGENS LATERAIS DO MAPA

\begin{tabular}{|c|c|c|c|}
\hline $\mathbf{N}^{\circ}$ & & $\mathbf{N}^{\circ}$ & \\
\hline $80_{/ /}$ & Pavoação do Rịo das velhas & $95 / /$ & Río de $\mathrm{S}^{\mathrm{ta}}$. Maria Cortona \\
\hline $79 / /$ & Quilonbo de S. Gonçalo. & $94 / /$ & Athé donde chegou a pose dos novos Entrantes. \\
\hline $78 / /$ & Serra de S. Pedro de Alcantra & $93 / /$ & Lugar de posse \\
\hline $77 / /$ & Ribeirão do Sacramento. & $92_{/ /}$ & Lugar do Salittre \\
\hline $76_{/ /}$ & Quilonbo da Sanbabaÿa & $91_{/ /}$ & [Quilonbo do Catigal] \\
\hline $75 / /$ & Ribeirão do bom Jezus & $90_{/ /}$ & O Quilonbo dos Santos Fortes \\
\hline $74_{/ /}$ & Quilonbo do Ambrozio & $89 / /$ & Rio da Santa Eria. \\
\hline $73 / /$ & Ribeirão da [mizericordia] & $88_{/ /}$ & Pouzo em Sima da Serra \\
\hline $72 / /$ & Fazenda da mizericordia & $87_{/ /}$ & Lugar que aparecerão muntas e grosas fumaças. \\
\hline $71_{/ /}$ & Rio de Santa Thareza & $86_{/ /}$ & O Ribeirão de S. Simão \\
\hline $70 / /$ & A Matriz da $\mathrm{Sr}^{\mathrm{a}} . \mathrm{S}^{\mathrm{ta}}$. Anna de Bambohÿ & $85_{/ /}$ & Lugar donde aparecerão muntas mais fumaças \\
\hline $69 / /$ & A Estançia de S. Simão & 84 & Rio de Santa Ursula \\
\hline $68 / /$ & Capella, e ponte de $\mathrm{S}^{\text {ta }}$. Maria, no Rio de S. Francisco & 83 & Morro escalvado \\
\hline $67 / /$ & Porto velho. & 82 & Corgo de São. Rafael \\
\hline 66 & A Snr ${ }^{\mathrm{a}}$. do livramento do Piuhÿ & 81 & Honze mil virgens \\
\hline $65 / /$ & Manoel Barboza & 60 & Tres Barras \\
\hline $64 / /$ & Fazenda da Capitinga. & 59 & Capella do Moraes \\
\hline $63 / /$ & Fazenda da ponte Alta & 58 & A barra da Itapeserica \\
\hline $62 / /$ & Fazenda do Quilonbo & 57 & Morro de Calhau de lima \\
\hline $61_{/ /}$ & Fazenda da Fromiga & 56 & A ponte do Lopes no pará \\
\hline $50 / /$ & Fazenda do Cappitão Manoel da Mota Botelho. & 55 & Fazenda de Francisco Ferreira \\
\hline $48_{/ /}$ & Ribeirão do pozo alegre & 54 & N. Sr ${ }^{\mathrm{a}}$. da pareçida do Claudio. \\
\hline $46_{/ /}$ & O Ribeirão de $\mathrm{S}^{\text {ta }}$. Anna & 53 & Capella do Carvalho \\
\hline $45_{/ /}$ & Fazenda do Camacho. & 52 & Arraÿal do Tamandoá. \\
\hline $42 / /$ & São Francisco de Paulla. & 51 & Fazenda do pouzo alegre \\
\hline $35 / /$ & Serra da Ibituruna & 49 & A ponte de pedra \\
\hline $34 / /$ & Rio grande & 47 & Fazenda do Corral \\
\hline $33 / /$ & São Goncalo da Ibituruna. & 44 & Fazenda da Cachoeira \\
\hline $32 / /$ & Capella da $\mathrm{Sr}^{\mathrm{a}}$. da Conceição & 43 & Bernardo Vieira \\
\hline $31_{/ /}$ & Rio do Jacarê. & 41 & A Sr${ }^{\mathrm{a}}$. da Oliveira \\
\hline $16_{/ /}$ & Fazenda do Capão groço. & 40 & Morro do Bicudo \\
\hline $15 / /$ & Capella de SantiAgó & 39 & Capella do Rí do peixe \\
\hline $8_{/ /}$ & Capella de S. Gonçallo & 38 & Ponte no Pará de Alexandre Pereira \\
\hline $7 / /$ & Ponte de S. Gonçallo & 37 & A bella Cruz, do Cappitão João Teixeira \\
\hline $6_{/ /}$ & Capella de S. [Sebastião.] & 36 & Fazenda de Guilherme Ferras \\
\hline $3 / /$ & A ponte Rial do Rio das mortes. & $30_{/ /}$ & O morro do quebra Cangalhas. \\
\hline \multirow[t]{22}{*}{$1_{/ /}$} & A Villa de São. João. & 29 & Fazenda de Bernado Homé \\
\hline & & 28 & Capella de S. João Bapptista \\
\hline & & 27 & Fazenda do Ouro fino. \\
\hline & & 26 & N. $\mathrm{S}^{\mathrm{ra}}$. da Gloria do pasa tempo. \\
\hline & & 25 & Fazenda da ponte Alta \\
\hline & & 24 & Capella do Desterro \\
\hline & & 23 & O Espigam da boa vista athe a lagoa \\
\hline & & 22 & Morro do Corisco \\
\hline & & 21 & Morro da boa vista \\
\hline & & 20 & Morro da Galga \\
\hline & & 19 & Fazenda de Manoel de Araújo Sam Paÿo. \\
\hline & & 18 & Fazenda de Francisco Pinto. \\
\hline & & 17 & O Río do peixe \\
\hline & & 14 & Fazenda de Josê Correa \\
\hline & & 13 & O Río de Santo Antonio \\
\hline & & 12 & A Capella da Laje \\
\hline & & 11 & A Lagoa Dourada \\
\hline & & 10 & A Capella do mosquito \\
\hline & & 9 & Capella de $\mathrm{S}^{\mathrm{ta}}$. Ritta \\
\hline & & 5 & Ponte no Río do Crandahÿ \\
\hline & & 4 & A Serra de São Jozê \\
\hline & & 2 & A Villa de São Jozê \\
\hline
\end{tabular}




\begin{tabular}{|c|c|c|c|}
\hline \multicolumn{4}{|c|}{ LEGENDAS ACRESCENTADAS AO CORPO DO MAPA PELA EDIÇÃO } \\
\hline $\mathrm{a}$ & Rio de Santo Antonio & aa & Petipê de $1_{/ /}$Legoa \\
\hline $\mathrm{b}$ & Rio Jacarề & $\mathrm{bb}$ & Morro do ferro \\
\hline $\mathrm{c}$ & vera cruz & $\mathrm{cc}$ & Serra do Sal \\
\hline $\mathrm{d}$ & Rio Parâ & $\mathrm{dd}$ & [perdas de materialidade e informações do documento] \\
\hline $\mathrm{e}$ & Rìo [ilegível] & ee & Capella de N. Sr ${ }^{a}$. das candeias [?] \\
\hline $\mathrm{f}$ & Rio Lambari & $\mathrm{ff}$ & Morro do Tamandoá \\
\hline $\mathrm{g}$ & Rio [ilegível] & gg & Rumo de calhau de lima a Piracuará \\
\hline $\mathrm{h}$ & Ribeirão da ponte Alta & hh & Serra [ilegível] \\
\hline $\mathrm{i}$ & Ribeirão de São Miguel & ii & Morro cavado \\
\hline $\mathrm{j}$ & Rio de Santa Anna & $\mathrm{jj}$ & Serra da Esperança \\
\hline $\mathrm{k}$ & Rio de São Francisco & $\mathrm{kk}$ & Paraizo \\
\hline $\mathrm{L}$ & Río Bambö̈ & LL & Serra de Piuhÿ \\
\hline $\mathrm{m}$ & Rio de Piuhy & $\mathrm{mm}$ & Morros talhador \\
\hline $\mathrm{n}$ & Ribeirão das Ajudas & $\mathrm{nn}$ & Cabeceras das Araras \\
\hline o & 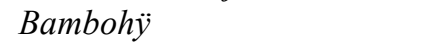 & oo & Morro do Palhano [?] \\
\hline $\mathrm{p}$ & Rio Sambora [?] & $\mathrm{pp}$ & Serra da Canastra \\
\hline $\mathrm{q}$ & Cabeceiras do Rio Perdiçaõ & $\mathrm{qq}$ & Morro do desempinhado \\
\hline $\mathrm{r}$ & Campinas & $\mathrm{rr}$ & A Serra da Marçella \\
\hline s & Ribeirão do quebra [Anzois] & ss & $\begin{array}{l}\text { Não pude exeminar esta grande extenção deste claro. Aonde está } \\
\text { o Andayá }\end{array}$ \\
\hline & & $\mathrm{tt}$ & Serra das Mangabas \\
\hline & & uu & Serra em Santa Fê \\
\hline & & $\mathrm{vv}$ & Serra de São Rafael \\
\hline & & ww & Serra de Santos Fortes \\
\hline & & $\mathrm{xx}$ & Mata do Salitre \\
\hline
\end{tabular}


Documento M02

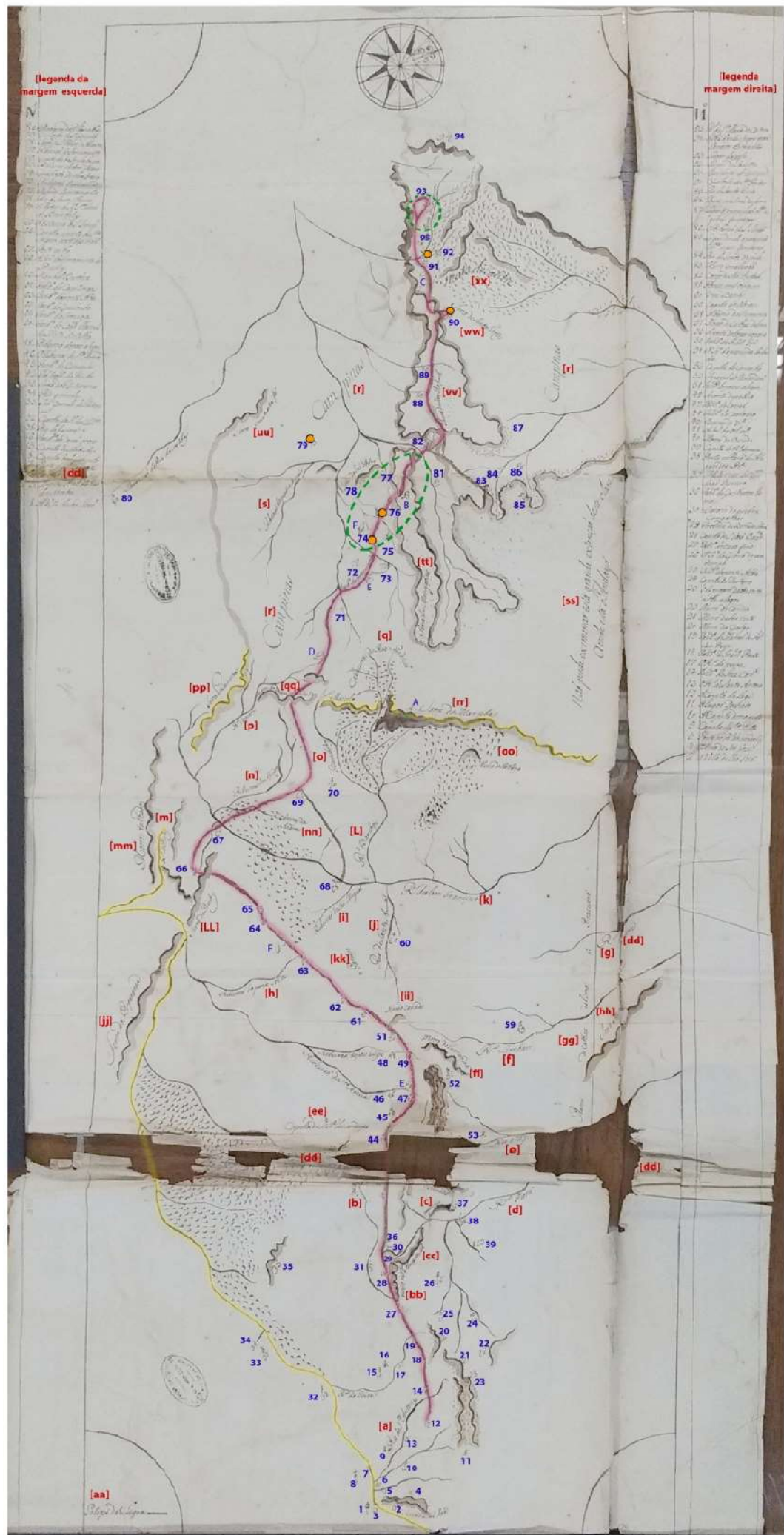

[Mapa do trajeto da expedição de 1769 de Ignacio Correya Pamplona] [ca.1769]. Papel. 1 mapa, 90x43cm. Manuscrito. Português. Biblioteca Nacional, Rio de Janeiro, coleção Ottoni, arquivo conde de Valadares, código: MS-575(1), folha 245 


\subsection{4 - 0 interior dos quilombos do Campo Grande na visão de seus destruidores}

Os relatos da expedição de 1769 foram "estampados" por seis desenhos de implantações de quilombos encontrados durante a jornada. Chamadas de "mapas" por seu autor, ilustrações como essas, detalhando o interior dos povoados quilombolas no século XVIII, são raras, sendo especialmente valiosas para nossa pesquisa.

É importante notar que, apesar da preciosidade que esse conjunto de documentos representa para o estudo da cultura e legado afrodescendente, as más conservações desses documentos os ameaçam de extinção. Os descuidos foram iniciados já na encadernação do códice (que não sabemos em que época foi efetuada), ocultando entre as costuras partes dos desenhos e fazendo com que as folhas dobradas dentro do pesado volume prejudiquem o suporte em papel. Durante as consultas ao códice, verificamos que os maus tratos aos documentos continuam. Por falta de estabilização do material (sem aplicação de reforço para o papel de trapo ou neutralização da tinta ferrogálica), partes significativas das informações estão se perdendo com rasgos, destaques de trechos do papel e migração de tinta para outras páginas. A menos que se invistam recursos financeiros e técnicos com urgência para a conservação desses documentos, a deterioração desses registros em breve fará com que esses quilombos encontrem uma nova ruína, agora de sua memória.

A Biblioteca Nacional, instituição mantenedora dos documentos, não disponibiliza imagens de alta resolução dos mesmos. Por esse motivo, para análise das imagens do relatório utilizo fotografias capturadas pessoalmente durante pesquisa no arquivo.

Como já apontado no início desta análise, a edição paleográfica dos documentos iconográficos foi executada pessoalmente. Como houve consulta aos originais, pudemos verificar que o material usado para suporte desses documentos é de papeis de trapo de alta gramatura onde, contra a luz, vemos a marca d'água da D\&C Blauw, enquanto textos e desenhos foram executados com tinta ferrogálica. Nos anexos apresento as imagens editadas, onde transcrevo os números do manuscrito em azul, e incluo algumas chamadas para auxílio da análise em vermelho entre colchetes (ver documentos G01 ao G06).

Adiante apresento nossa leitura dos mapas dos quilombos, agregando informações extraídas dos relatórios escritos e mapa do trajeto da expedição de Pamplona de 1769. Exibo tais desenhos de implantações na ordem de chegada da expedição aos quilombos. 


\section{OS QUILOMBOS AO PÉ DA SERRA DA MARÇELLA}

A "Notícia diária" nos conta que um destacamento menor da expedição de 1769, liderado por José Cardoso, saiu da fazenda de São Simão ${ }^{[69]}$, próxima à nova Matriz de Bambohÿ ${ }^{[70]}$, para exploração dos arredores. Essa bandeira retornou à fazenda um mês depois, trazendo um prisioneiro e notícias de negros fugidos. ${ }^{61}$

As localizações dos dois quilombos encontrados nessa primeira exploração dos sertões do Bambohÿ não foram expostas no "Mapa do Trajeto da Expedição [...]”. Pelos nomes dados a eles, sabemos que ambos ficavam próximos ao rio da Perdição ${ }^{[q]}$.

A partir da ausência de registros de passagem nesses quilombos na "Notícia diária" e no "Memorial dos mapas", compreendemos que os memorialistas da expedição não estiveram nessa região. Ou seja, tais quilombos foram invadidos pela bandeira destacada do corpo principal das tropas, enquanto os demais integrantes da expedição ficaram na fazenda de Pamplona.

Os desenhos de implantações dos dois quilombos nos arrabaldes do rio da Perdição, portanto, devem ter sido executados a partir de informações fornecidas pelo prisioneiro e pelos integrantes do destacamento militar que os destruíram. Com isso em mente, entramos nas ilustrações dos mesmos.

\footnotetext{
${ }^{61}$ ANBNRJ, 1988, p.59-64
} 


\section{QUILOMBO DE HUM DOS BRAÇOS DA PERDIÇAÕ}

O mapa do quilombo de "hum dos braços da perdiçaõ" ${ }^{62}$ [sic] apresenta a povoação rodeada de "Mattos" (item 6), em meio dos quais vemos traçados sinuosos que aparentam ser três cursos d'água, que se juntam em um único veio na parte inferior da imagem. Esses córregos dividem em três partes a clareira de formato irregular em meio à mata. Uma das partes dessa clareira era ocupada por "Mandiocal" (item 5), a outra por "Algudoaes" (item 4) e uma "Agoada com hua bica" (item 3). Tal bica indica que a captação de água no quilombo era feita através de algum dispositivo construído junto ao veio d'água. Já a terceira clareira na mata (ao centro) tinha algodoais e mandiocal junto com as construções.

As edificações do núcleo central do quilombo foram desenhadas com quadrados acrescidos de triângulos ao topo, aparentando representar paredes e cobertura em vista. Seis construções nas margens da clareira, que julgamos serem casas, envolvem uma "Caza do Thear" (item 2) e uma "Caza do Rey". A presença de algodoais e casa de tear pressupõe a fabricação de tecidos pelos quilombolas.

É difícil entender com precisão que tipo de figura de liderança tinha essa povoação para ter sido considerada pelo memorialista da campanha como um "Rey". Ressaltamos que a localização da "Caza do Rey" (item 1) bem ao centro do núcleo habitável, assim como sua representação como a maior das construções do quilombo, atribui a ela um configuração espacial de destaque dentro do povoado.

Próximo às casas do rei e de tear, há o desenho de uma cruz entre dois totens menores. Essa cruz poderia sugerir que a comunidade tivesse alguma relação com cristianismo, mas como não foi posicionada no desenho sobre construção (como costumavam serem representadas capelas ou igrejas), nossa aposta é de que tal cruz entre totens indicava um cemitério. A existência desse cemitério localizado ao centro do quilombo, junto à casa do rei, pode ter relação com hábitos religiosos de reverência aos ancestrais, com manutenção de seus restos mortais junto às habitações e locais de culto.

Nesse desenho de implantação não foram inseridas rosa dos ventos ou escala gráfica. A ausência da última impede que possamos tomar medidas aproximadas da área do núcleo habitável do quilombo ou de suas edificações. No entanto, por contar com apenas oito

\footnotetext{
${ }^{62}$ Quilonbo de hum dos braços da perdiçaõ [sic]. [1769?]. Papel. 2 folhas. Manuscrito. Português. Biblioteca Nacional, Rio de Janeiro, Coleção Ottoni, arquivo conde de Valadares, código: MS-575(1), folha 250-251. Ver desenho e textos editados no fim deste item no doc.G01.
} 
construções, parece se tratar de uma quilombo pequeno, com menor proporção que as do Ambrozio e ou do Sam Gonçalo, que veremos adiante. Nesse retrato não foram exibidos casa de ferreiro, trincheiras ou buracos com estrepes. Como recurso para defesa foi apresentado apenas um morro ${ }^{[\mathrm{Bm}]}$, que poderia ser usado para avistar o entorno, permitindo, por exemplo, que tivessem tempo para reagir à aproximação de inimigos. Tal morro não foi identificado por legenda, mas seu desenho tem o mesmo padrão de traçado sinuoso usado para identificar os morros nos mapas de outros quilombos.

Interrogamos-nos por que um quilombo com apenas seis construções que poderiam servir de habitação, produziria tecidos próprios e contaria com a liderança de rei. Talvez as casas abrigassem famílias extensas, como muitos moradores em cada uma. Talvez esse tear, cemitério e casa de rei servissem não apenas aos habitantes das casas que os rodeavam mas, também, à outras pessoas que não moravam ali. O memorial dos mapas aponta a relação desse quilombo de "hum dos braços da perdiçaõ", próximo a outro quilombo no mesmo rio, com o Sambabaÿa, para onde teriam se retirado no ano anterior para "fazerem roça",63. É razoável pensar que os moradores do Sambabaÿa frequentassem o quilombo de "hum dos braços da perdiçaõ" para, por exemplo, enterrar seus mortos, fabricar tecidos e encontrarem com seu rei? Analisaremos esse problema mais adiante à luz de outros elementos.

${ }^{63}$ ANBNRJ, 1988, p.102 


\section{QUILOMBO CHAMADO DO RIO DA PERDIÇAÕ}

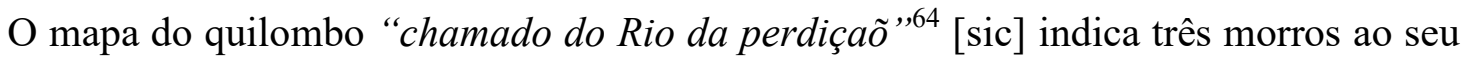
redor: o do tigre (item 3), do Uribu (item 4) e mais um desenho de morro não identificado, abaixo à esquerda. Tais morros podiam ser usados como mirantes. A imagem apresenta o mesmo tipo de hachura que, em outros desenhos, foi usada para caracterizar as matas que rodeavam os quilombos. Em meio às matas encontramos duas linhas sinuosas que se juntam em uma única, que devem representar veios d'água ${ }^{[\mathrm{Pc}]}$. Em espaço aberto com formato irregular rodeado pelas matas, ao pé do morro do Uribu, encontramos o núcleo habitável do quilombo. A abundância de morros no entorno da povoação mostra que essa foi implantada em um fundo de vale.

O núcleo do quilombo possuía uma "roça" (item 5) próxima à nove construções. Representadas em vista (assim como no quilombo "hum dos braços da perdiçaõ" vizinho), foram especificados os usos de duas das maiores construções: as "Cazas do Thear" (item 1) e a "Caza do Conselho" (item 2). Ambas estão dispostas na extremidade esquerda do núcleo do quilombo, próximas ao limite da mata e do curso d'água. Novamente temos uma cruz entre dois totens menores, situada na borda daquilo que parece ser uma praça central entre as construções, espaço que nos parece apropriado chamar de "terreiro".

O desenho não aponta plantio de algodão, porém a presença de casas de tear mostra que fabricavam algum tipo de tecido, que podia ser usado para produzir vestimentas, redes de dormir e afins. A existência do tear indica boa autonomia na produção de subsistência dos quilombolas. Nesse povoado são ausentes indicações de casa de ferreiro ou armadilhas com estrepes. Não há indicação de petipé ou rosa dos ventos na implantação. Como não há escala gráfica, não podemos estimar a área do povoado a partir do desenho.

Segundo esse retrato, o quilombo "do Rio da perdiçã̃" possuía apenas sete construções que poderiam ser destinadas à moradia. $\mathrm{O}$ tamanho de cada uma das casas e o número de habitantes nos são desconhecidos. Apesar da rusticidade do desenho desse quilombo, os equipamentos nele descrito indicam uma sofisticação na organização social dos quilombolas. Nos chama a atenção a casa de conselho (próxima à mata) e o terreiro com cemitério (no centro do povoado). Esses dois equipamentos teriam uma função social e

\footnotetext{
${ }^{64}$ Quilonbo chamado do Rio da perdiçã̃ [sic]. [1769?]. Papel. 2 folhas. Manuscrito. Português. Biblioteca Nacional, Rio de Janeiro, Coleção Ottoni, arquivo conde de Valadares, código: MS-575(1), folha 258-259. Ver desenho e textos editados no fim deste item no doc.G02
} 
religiosa? Esse conselho serviria para a tomada de decisões pelos moradores desse núcleo quilombola ou reuniria também outros habitantes da região associados aos primeiros? Buscaremos explorar em pouco mais essas questões adiante. 


\section{QUILOMBO DO AMBROZIO}

O quilombo Ambrozio ${ }^{[74]}$ surge na narrativa da expedição de 1769 após travessia do rio da Misericórdia ${ }^{[73]}$, quando avistaram um morro que acreditaram ser o da "Gorita", lugar de sentinela do quilombo "não afamado nestas minas". Segundo os diários, no quarto dia de marcha no sertão para além da serra da Marçella, as tropas chegaram no antigo povoado "onde ademiramos os arruinados idifícios e multiplicados fojos, todos crivados de estrepes de que era composto o mesmo Quilombo”.

A tropa aquartelou próximo ao quilombo, em trecho queimado de restingas de capoeira (letra F), para procurar ouro (sem resultados), plantar milho, feijão e algodão, após passar fogo na terra. Seguindo viagem para além do Rio das Onze mil virgens ${ }^{[81]}$ o Mestre destinou local para o novo Arraial da Senhora da Conceição e delimitou fazenda para si entre esse arraial e o quilombo do Ambrozio. No mês seguinte, no retorno da expedição ao local, viram nascido e bonito o milho que a própria tropa plantou nas terras quilombolas. ${ }^{65}$

No mapa do trajeto da expedição (ver M02), o quilombo do Ambrozio ${ }^{[74]}$ ficava junto a restingas de capoeira (letra "F"), tendo ao norte a serra das Mangabas ${ }^{[\mathrm{tt}]}$ e o córrego do Bom Jesus $^{[75]}$; ao leste o rio de São Francisco ${ }^{[\mathrm{k}]}$ e a serra da Marçella ${ }^{[\mathrm{rr}]}$; ao sul o rio Santa Tharesa $^{[71]}$ e áreas de campinas $^{[\mathrm{r}]}$; ao sudoeste a serra de Santa $F \hat{e}^{[\mathrm{uu}]}$ e o quilombo Sam Gonçalo $^{[79]}$; a noroeste o quilombo Sambabaÿa ${ }^{[76]}$.

O desenho de implantação do quilombo do Ambrozio $^{66}$ (doc. G03) teve a rosa dos ventos destacada, devido à reação do papel à tinta ferrogálica. No entanto, as marcas de migração do pigmento para a outra folha do documento nos permitem deduzir sua posição original, como vemos na foto da edição.

Na ilustração vemos ao nordeste o morro de "gorita" (item 2); restingas de matos com vertentes de água (item 5) cercando a antiga povoação ao norte, oeste e sul, enquanto o trecho leste possui um "campo limpo" (item 9), que também é encontrado próximo às matas ao sul e norte. O núcleo do quilombo é cercado por fosso (item 1) com 15 palmos de largura

\footnotetext{
${ }^{65}$ ANBNRJ, 1988, p.67-71/ p.79/ p.101.

${ }^{66}$ Quilonbo do Ambrozio. [1769?]. Papel. 1 folha. Manuscrito. Português. Biblioteca Nacional, Rio de Janeiro, Coleção Ottoni, arquivo conde de Valadares, código: MS-575(1), folha 238-239. Ver desenho e textos editados no doc.G03
} 
(aproximadamente 3,54 metros), nas faces leste, sul e, aparentemente, também na norte ${ }^{67}$, ficando aberto no trecho oeste, onde há um brejo com buraco e estrepes (item 4). Passado o fosso há uma trincheira (item 8), que delimita o centro habitável por todos os lados, formando um quadrado em planta. Entre a trincheira e fosso temos estrepes (item 6), cujo desenho se repete dentro do fosso e para além do mesmo, cercando a povoação. Em todo o perímetro externo da trincheira temos "Goritas" (item 3), uma de cada lado visíveis do desenho, com indício outras duas goritas na face norte.

No interior do espaço retangular formado pelas fortificações encontramos trinta e três “Cazas" (item 7) dispostas em dois lances, acompanhando a trincheira, deixando o centro do terreno livre de construções. As casas são representadas em planta de formato retangular, com sua maioria dividida ao meio por uma linha transversal. Ao menos uma das casas não mostra divisões internas ${ }^{[\mathrm{Ab}]}$ e uma delas, próxima a praça central, foi dividida em 4 partes $^{[\mathrm{Aa}]}$.

Esse conjunto do Ambrozio, retratado pelos expedicionários luso-americanos de 1769, foi descrito como ruínas do antigo quilombo, cuja localização aproximada era previamente conhecida pela tropa, tendo sido extinto em momento anterior. As construções nos tempos da existência desse povoado deveriam estar parcial ou totalmente destruídas durante a passagem de Pamplona. Assim, esses observadores não poderiam definir o uso das edificações ou tipos de produtos feitos no quilombo quando ativo.

A partir da proporção gráfica inserida na legenda, pensando o "Petipé de 5 passos" (item X) como equivalente a 1 metro por passo, as construções teriam aproximadamente 10x7 metros, total de $70 \mathrm{~m}^{2}$ cada, a trincheira com 100x100metros, fechando área de $10.000 \mathrm{~m}^{2}$, enquanto o núcleo fortificado do Quilombo do Ambrozio até o limite do fosso ocuparia aproximadamente de $125 \times 125 \mathrm{~m}^{2}$, com área total de $15.625 \mathrm{~m}^{2}$. O conjunto era rodeado por restingas de matos com vertentes de água e por um campo limpo na face leste, com um morro próximo da povoação, que serviria como mirante para espiar a aproximação de inimigos.

\footnotetext{
${ }^{67}$ Parte do centro do desenho foi omitida pela encadernação. Deduzimos a continuidade do fosso (item 1) nesse trecho pela curvatura no canto superior esquerdo das linhas paralelas que o delimitam, e pela presença do número "6" (Distançia entre foço, e trinxera com estrepes) no limite visível da folha.
} 


\section{QUILOMBO DA SAMBABAŸA}

Segundo a "Notícia Diária" da campanha de 1769, os expedicionários saíram a cavalo do Ambrozio ${ }^{[74]}$ rumo noroeste, passaram pelo córrego do Bom Jesus ${ }^{[75]}$ e chegaram no mesmo dia ao quilombo da Sambabaÿa ${ }^{[76]}$. Uma das bandeiras da mesma expedição tinha queimado o quilombo antes da chegada de toda tropa, tendo nosso memorialista visto seus vestígios e tomado informações pelo bandeirante para fazer o desenho da povoação. A expedição plantou feijão, algodão e um alqueire ${ }^{68}$ de milho sobre a roça que estava queimada.

Antes da chegada de toda a expedição, a bandeira liderada por José Cardoso prendeu um "negro" que se retirava do Sambambaÿa para o antigo quilombo do Corisco. Os demais habitantes do quilombo da Sambabaÿa fugiram, sendo procurados pelas tropas mais adiante no quilombo de Santos Fortes ${ }^{[90]}$. Através do prisioneiro, o memorialista teve notícia de que os habitantes do Sambabaÿa "estavam em um Quilombo em um dos Braços da perdição, ao pé de outro Quilombo na mesma perdição" tendo se retirado dele "o ano passado a fazerem roça na Samambaia por lhe ficar perto para conduzirem o seu Mantimento e dai melhor estabalecer" $" 69$.

Seguindo para além do rio das Onze mil virgens ${ }^{[81]}$, o Mestre delimitou a área entre o córrego do Sacramento ${ }^{[77]}$, o córrego do Bom Jesus ${ }^{[75]}$ e a serra de São Pedro de Alcantra ${ }^{[78]}$ (polígono que abrange o quilombo da Sambabaÿa ${ }^{[76]}$ ), para o estabelecimento do novo arraial de Nossa Senhora da Conceição. ${ }^{70}$

No "Mapa do Trajeto da expedição de 1769 [...]” (M02), o quilombo da Sambabaÿa ${ }^{[76]}$ fica próximo do caminho velho de Goiás, junto à área identificada como “capão do mato chamado Capetinga" ${ }^{,[\mathrm{F}]}$. O quilombo tinha a serra das Mangabas ${ }^{[\mathrm{tt}]}$ ao norte; a serra da Marçella $^{[\mathrm{rr}]}$ e o rio de São Francisco ${ }^{[\mathrm{k}]}$ ao leste; o ribeirão do quebra Anzois ao sul; a serra de São Pedro de Alcantra ${ }^{[78]}$ ao oeste. Tomando as medidas do mapa, essa comunidade estava a aproximadamente 6 léguas de distância do quilombo de São Gonçalo ${ }^{[79]}$ e a cerca de 1,5 léguas do Ambrozio ${ }^{[74]}$.

\footnotetext{
${ }^{68}$ Entendemos alqueire como uma relação entre terras cultivadas e sua capacidade de produção de safras. Assim, quanto mais fértil a terra, menor a área de plantio necessária para colheita de uma cota de alimentos, por isso a medida é variável de acordo com região.

${ }^{69}$ ANBNRJ, 1988, p.102

${ }^{70}$ ANBNRJ, 1988, p.70 e p.101
} 
A ilustração do quilombo da Sambabaÿa ${ }^{71}$ (doc. G04), nos apresenta uma clareira na mata $^{72}$ de formato irregular, delimitada na parte inferior por traço sinuoso que aparenta ser um curso d'água. No interior dessa clareira temos pouco mais de uma dezena de construções retangulares, aparentemente representadas em planta.

A maior parte das edificações são identificadas como "cazas" (item 7), estando algumas divididas ao meio por um traço transversal, outras sem divisão. A repartição de uma das casas $^{[\mathrm{Sa}]}$ em oito partes (assim como a divisão em quatro partes de uma casa no Ambrozio) mostra que essas segmentações não representam a divisão de águas dos telhados em planta. Assim, é provável que essas repartições se referissem à quantidade de ambientes internos das construções. Ou cada módulo correspondia à habitação de uma família, com algumas unidades geminadas formando uma só construção.

As habitações rodeiam duas outras construções ao centro do núcleo quilombola. Uma também foi assinalada como casa, sendo a maior entre todas as casas ${ }^{[\mathrm{Sa}]}$ e estando dividida em oito compartimentos. A outra era a "Caza e forge de ferreiro" (item 6), que não apresenta divisões internas. À direita, isolada das demais construções, tendo a mata como vizinha em três lados, há uma "Caza de audiençia com aSentos" (item 1), com planta retangular, sem divisões internas.

Indicado no item "V" da legenda, o "Cortume de Couros" apresenta dificuldade de localização do desenho ${ }^{73}$. Tal curtume pode estar velado pela encadernação do códice, que suprimiu toda extremidade esquerda do desenho que, por má conservação, também perdeu sua rosa dos ventos no canto inferior direito. No estudo paleográfico, buscando um signo cuja morfologia e dutos caligráficos usados para representar o número " 5 " nesse e em outros desenhos do relatório, percebemos que existe um "5" na imagem, ainda que borrado devido à

\footnotetext{
${ }^{71}$ Quilonbo da Sambabaÿa. [1769?]. Papel. 1 folha. Manuscrito. Português. Biblioteca Nacional, Rio de Janeiro, Coleção Ottoni, arquivo conde de Valadares, código: MS-575(1), folha 243. Ver desenho e textos editados no doc.G04

${ }^{72}$ A larga faixa hachurada possui mesmo padrão de outros desenhos onde são identificados com "matos"

${ }^{73}$ Em seu livro Flávio Gomes indica a casa de audiência com construção no centro do quilombo ${ }^{\text {[Sa] }} \mathrm{e} \mathrm{o}$ curtume de couros como a maior construção, isolada perto da mata. No entanto, ao realizarmos a leitura paleográfica do documento percebemos que a morfologia e dutos caligráficos dos numerais do manuscrito inviabilizam a interpretação do autor. Ver GOMES, Flávio dos Santos. A hidra e os pântanos: mocambos, quilombos e comunidades de fugitivos no Brasil (séculos XVII-XIX). São Paulo: Ed. UNESP: Ed. Polis, 2005. p.374.
} 
deterioração do documento. Assim, esse cortume foi representado por um simples traço mais grosso, localizado no interior do quilombo na borda da mata.

Ao redor das construções temos uma roça "que se plantou" (item 4), que também aparece em duas clareiras menores na outra margem do curso d'água, juntamente com o plantio de milho (item 2). No canto superior, na divisa com a mata existe um mandiocal (item 3). Esse cultivo entre as casas podia se referir às roças de milho, feijão e algodão feito pela expedição sobre o quilombo após queimá-lo. Os relatórios não falam das tropas terem plantado mandioca. A ilustração do Sambabaÿa não apresenta pilões, teares ou silo para guarda de grãos.

Acima à direita temos o "morro que servia de gorita "(item 8), cujo uso para avistar os inimigos foi exposto na descrição. A imagem não assinala fossos, buracos com estrepes, trincheiras ou outros dispositivos de defesa.

Como vimos nos relatórios da expedição, os quilombolas fugiram antes da chegada da bandeira que queimou o Sambabaÿa, tendo o desenhista chegado depois do fogo. Novamente a representação do quilombo foi feita a partir de ruínas, sem que seu retratista conhecesse a dinâmica dessa povoação ou sua aparência enquanto ativo.

Tomando o petipé indicado na legenda (e considerando que 1 passo tenha cerca de 1 metro), temos as seguintes medidas aproximadas: clareira principal com $3.000 \mathrm{~m}^{2}$; casas entre $6 \mathrm{~m} \times 5 \mathrm{~m}=30 \mathrm{~m}^{2}$ e $12 \times 7 \mathrm{~m}=84 \mathrm{~m}^{2}$; casa de oito compartimentos ${ }^{[\mathrm{Sa}]}$ com $15 \times 5 \mathrm{~m}=75 \mathrm{~m}^{2}$; casa e forje de ferreiro com $5 \times 4 \mathrm{~m}=20 \mathrm{~m}^{2}$; casa de audiência com $15 \times 6 \mathrm{~m}=90 \mathrm{~m}^{2}$.

Como dito anteriormente, o Sambabaÿa aparece nos diários como associado a outro quilombo na bacia do rio da Perdição, tendo os habitantes do último ido fazer roça, conduzir seu mantimento e melhor se estabelecer no Sambabaÿa um ano antes. Outro aspecto que nos chama a atenção é a proximidade da casa de audiência com a mata, o que também foi observado no quilombo "chamado do Rio da perdiçaõ". Exploraremos novamente essas constatações no próximo capítulo. 


\section{QUILOMBO DE SAM GONÇALO}

O memorialista dos mapas avistou o quilombo de Sam Gonçalo do alto da serra de São Rafael $^{[\mathrm{vv}]}$, espigão por onde se chegava ao caminho velho de Goiás. Dali uma parte dos expedicionários, liderados pelo Tenente José da Serra Caldeira, se destacaram do grupo para abater o quilombo. Tal bandeira aprisionou apenas um quilombola que estava fazendo farinha, tendo os demais fugido, e se apropriou de "vários trastes e panos de Algudões feitos ricamente pelos mesmos Negros". ${ }^{74}$

No "Mapa do Trajeto da expedição de 1769[...]”, o quilombo de São Gonçalo ${ }^{[79]}$ encontra-se junto à área de campina ${ }^{[\mathrm{r}]}$, tendo ao norte um rio e o espigão da serra de São Rafael $^{[\mathrm{uu}]}$; ao leste o rio de São Francisco ${ }^{[\mathrm{k}]}$ e serra da Marçella ${ }^{[\mathrm{rr}]}$; ao sul o ribeirão Quebra Anzóis $^{[\mathrm{s}]}$ e a serra de Santa Fê ${ }^{[\mathrm{vv}]}$.

Tomando as distâncias em linha reta nesse mapa, através do Petipé indicado ${ }^{\text {[aa], }}$ sabemos que o quilombo de Sam Gonçalo ficava a aproximadamente 6 léguas do Sambabaÿa ${ }^{[76]}$ do Ambrozio ${ }^{[74]}$, distancia que levaria cerca de seis horas de marcha para ser transposta, sem considerar as dificuldades advindas da geografia do local. A povoação lusoamericana do Rio das Velhas ${ }^{[80]}$ ficava a cerca de 11 léguas desse quilombo, mas a serra de Santa $F \hat{e}^{[v v]}$ separava ambas as povoações, o que deveria dificultar a circulação entre ambas. O caminho velho para Goiás e a estrada nova de Pamplona, ao nordeste, ficavam distantes do Sam Gonçalo, se comparado ao Sambabaÿa ou Santos Fortes ${ }^{[90]}$, sendo todos esses quilombos ativos naquele momento.

De acordo com o desenhista da campanha de Pamplona, a implantação do quilombo de Sam Gonçalo ${ }^{75}$ era envolta por matos (item 9) e limitada por uma larga trincheira (item 5) com 10 palmos de altura (aproximadamente 2,30 metros) que circundava todo o quilombo. Essa trincheira era atravessada por uma entrada com dois fojos (item 4), uma saída com estrepes (item 8), e dois pares de buracos por onde os quilombolas fugiram (item 2). A ilustração não exibe morro próximo ao quilombo, nem escala gráfica.

A circunferência central da povoação, formada pelo espaço no interior da trincheira, é dividida em duas partes no desenho.

\footnotetext{
${ }^{74}$ ANBNRJ, 1988, p.101-102

${ }^{75}$ Quilonbo de Sam Gonçalo. [1769?]. Papel. 1 folha. Manuscrito. Português. Biblioteca Nacional, Rio de Janeiro, Coleção Ottoni, arquivo conde de Valadares, código: MS-575(1), folha 244. Ver desenho e textos editados no doc.G05
} 
No trecho sul havia duas edificações e uma horta (item 3), sendo que boa parte do espaço foi representado vazio. É possível que essas duas construções isoladas fossem casas de moradores recém-chegados, casas de reis e lideranças sagradas ou casas para grupos etários ou de gênero temporariamente afastados da comunidade ${ }^{76}$. É possível também que esse trecho fosse usado para plantações, com as duas construções sendo usadas como paióis ${ }^{77}$.

No trecho norte temos algumas construções não identificadas, dois conjuntos de casas conectadas umas as outras por paredes (item 6), uma "casa de pilões" (item 7) e uma "casa de tear" (item 10), cujo alinhamento entre elas forma um espaço livre ao centro sem construções além de uma "casa de ferreiro" (item 1) com uma edificação ao lado.

Os conjuntos de casas conectadas por paredes (item 6) - dois trios na parte norte e mais um par de casas ligadas entre si na parte sul - são representados por quadrados culminados em triângulos, parecem se referir a habitações com paredes e coberturas independentes, atadas por paredes externas, e não a uma edificação única.

Ainda que a ilustração não apresente os locais de outras plantações além da horta, a presença da casa de pilões e de tear, assim como a informação sobre as farinhas e tecidos, indicam a existência de culturas de algodão, milho, mandioca ou similares em quantidade suficiente para o confisco pela tropa ser motivo de notação no relatório. Talvez as roças ficassem em outra área, talvez ficassem na metade sul do núcleo, apenas não sendo indicadas no desenho. O armazenamento de grãos ou farinha poderia ocorrer na própria casa pilões ou em construção própria não identificada.

A fabricação de tecidos, farinhas e manipulação do ferro, mostram que essa comunidade tinha uma economia de subsistência bem estabelecida. O sistema de defesa desse quilombo era eficiente o bastante para que a maioria de seus habitantes fugisse antes da chegada das tropas bélicas, optando por não as enfrentarem.

A casa de ferreiro constitui um rico tema para discussão. $O$ trabalho com ferro nesse quilombo indica que poderiam produzir suas próprias ferramentas para cultivo da terra, ou mesmo de armas. Significa também que havia jazidas desse minério disponíveis. A escolha da posição central no quilombo poderia derivar do caráter coletivo da atividade, mas a casa de

\footnotetext{
${ }^{76}$ GOMES, 2005, p.379-380.

${ }^{77}$ As indicações desses tipos de depósitos são comuns nos relatos das tropas antiquilombos (ver: BARBOSA, 1972, p.39, p.49, p.67-68), sendo verificado também no "Mapa de todo o campo Grande [...]" (analisado no item 2.3 desta dissertação).
} 
tear e de farinha (que também demandariam trabalho comunitário) ficavam nas bordas do terreiro. Talvez a posição fosse escolhida por sua importância social, simbólica ou política.

Apesar do desenho não mostrar capela ou cruzes, segundo o "Memorial do mapa", o nome São Gonçalo foi atribuído pelos próprios quilombolas em devoção ao santo ${ }^{78}$. Dessa maneira, os quilombolas poderiam praticar alguma forma de devoção sincrética derivada do catolicismo.

${ }^{78}$ ANBNRJ, 1988, p.102 


\section{QUILOMBO DOS SANTOS FORTES}

Na Notícia diária aparece um sítio que o Mestre de Campo intitulou de Santos Fortes e, no retorno da expedição, o memorialista diz que voltaram ao quilombo dos Santos Fortes onde teria ficado "um pardo e dois pretos" cuidando de um animal doente. Esses suspeitavam que os "calhambolas" os espreitavam durante a noite, dizendo que avistaram fogos próximos que só poderiam ser dos Negros, pois no "Sertão" não morava mais ninguém ${ }^{79}$.

De acordo com o "Memorial dos mapas", a tropa foi ao quilombo de Santos Fortes, onde procuraram fugidos do Sambabaÿa, "e neste Lugar os destroçou e saquiou grande quantidade de panos de Algudões e feitos nos dito Quilombo e outros mais Roubos que eles tinham feito, ali nos demoramos de se plantar a Roça que eles tinham queimado". Por se demorarem aí para plantar, houve tempo de fazer seu desenho. ${ }^{80}$

No "Mapa do Trajeto da expedição de 1769[...]" (M02) o quilombo dos Santos Fortes $^{[90]}$ encontra-se junto à serra de Santos Fortes ${ }^{[\mathrm{ww}]}$, tendo a Mata do Salitre ${ }^{[\mathrm{xx}]}$ ao noroeste; área de campina ${ }^{[\mathrm{r}]}$ ao nordeste; a Serra de São Rafael ${ }^{[\mathrm{VV}]}$ ao sul; estando bem próximo da picada velha para Goiás e do quilombo do Catinguá ${ }^{[91]}$ ao oeste (a menos de 4 léguas de distancia em linha reta).

O desenho do quilombo de Santos Fortes ${ }^{81}$ (doc. G06) mostra uma clareira de formato irregular em meio à hachura que representa a mata, com um curso d'água dividindo o espaço em duas partes.

No trecho sudoeste temos nove "Cazas do quilonbo" (item 1) ${ }^{82}$, representadas em planta, com forma retangular e divididas em duas partes cada uma. Na parte superior da clareira foi indicada a roça plantada pela expedição (item 2), sobre a plantação que os quilombolas queimaram antes da chegada das tropas.

\footnotetext{
${ }^{79}$ ANBNRJ, 1988, p.73 e p.79

${ }^{80}$ ANBNRJ, 1988, p.102.

${ }^{81}$ [Quilonbo] dos Santos fortes. [1769?]. Papel. 1 folha. Manuscrito. Português. Biblioteca Nacional, Rio de Janeiro, Coleção Ottoni, arquivo conde de Valadares, código: MS-575(1), folha 253. Ver desenho e textos editados no doc.G06.

${ }^{82}$ Duas casas caíram da folha por falta de estabilização do suporte de papel. Podemos ver parte delas na imagem publicada nos anais da instituição de 1988. Essa reação à tinta ferrogálica também fez com que o desenho da rosa dos ventos se destacasse do papel, mas devido às marcas da migração da tinta para folha anterior, é possível reconstituir sua posição original, como se vê na foto da edição paleográfica.
} 
O desenho não indica morros, mas pelo relato sabemos que o quilombo estava junto à serra. Também não foram assinalados buracos com estrepes ou trincheiras. Entre os quilombos representados, o Santos Fortes aparenta ser o mais simples deles.

Através do petipé indicado, podemos estimar que a clareira apresentava cerca de $60 \mathrm{x}$ 90 metros em seus limites mais extremos, com área aproximada de $3.000 \mathrm{~m}^{2}$, enquanto as nove casas teriam entre $4 \mathrm{~m} \times 5$ metros e $4 \mathrm{~m} \times 8$ metros, ou seja, entre $20 \mathrm{~m}^{2}$ e $32 \mathrm{~m}^{2}$. 


\section{QUILOMBO DO CATIGAL}

Segundo a Notícia diária, no dia 01 de novembro os tropeiros foram

"dormir ao pé de um Ribeirão chamado Salitre, aonde esteve já muntos anos e há poucos se tornou a retificar um quilombo chamado o Catiguá ${ }^{[91]}$, de mais de cento e cinquenta jiraus, sendo certo que foi quilombo de munta força e de munto poder, o que claramente se evidenceia, porque havendo nestas paragens muntos matos, os mais próximos ao lugar do mesmo quilombo todos estão destruídos e safados de muntas e repetidas plantas que os Negros ali fizeram, e agora de próximo se retiraram temoratos das nossas Bandeiras, aqui colhemos algum milho que era o resto que eles tinham deixado e nos serviu para dar a algum cavalo mais frouxô."

"Aqui se armou um Arraial de casas de capim mui bem airoso, porque a paragem é de Si mesmo mui vistosa e agradável. Aqui se apanharam bastantes caças de viados, perdizes, e Jacuses, aqui no dia em que chegamos foi Simão Rodrigues ao Rio, e nele pescou com pouco espaço treze peixes, com o nome de Tobaranas de munto boa grandeza." 83

É interessante notar o apontamento do memorialista sobre os espaços desmatados pelos quilombolas para agricultura, relacionando as proporções das clareiras com o poder e força do quilombo. Os documentos detalham a abundância de pesca, caça e fontes de água naquele local, mas não falaram das construções quilombolas encontradas em 1769, apenas da existência de mais de 150 habitações no passado. A presença dos quilombolas foi marcada pelos restos de suas colheitas, que foram apropriados pela expedição de Pamplona.

Esse quilombo não foi descrito no "Memorial do Mapa", nem teve seu interior retratado pelos desenhos. A localização do quilombo do Catigal ${ }^{[91]}$ foi indicada no "Mapa do Trajeto da expedição de 1769 [...]" (M02), distando menos de 4 léguas do quilombo dos Santos Fortes ${ }^{[90]}$, ao pé do espigão da Serra de São Rafael, estando em meio à mata do Salitre ${ }^{[\mathrm{xx}]}$, entre as margens do Rio Santa Maria Cortona ${ }^{[95]}$ e outro curso d'água não nomeado. A supor pela surpresa que a Paragem do Salitre ${ }^{[92]}$ suscitou nos relatores, parece que o local era até então desconhecido pelos exploradores da coroa portuguesa. Foram ressaltadas as nascentes de água salgada e a abundância de caça e pesca na região.

\footnotetext{
${ }^{83}$ ANBNRJ, 1988, p.75.
} 
Pouco adiante do lugar do Salitre, o Mestre de Campo decidiu encerrar o progresso das tropas, proclamando a posse para o Estado portuguesa de todo território avançado ${ }^{84}$ até o pé da serra ${ }^{[94]}$ próxima ao Salitre no mapa.

${ }^{84}$ ANBNRJ, 1988, p.102. 


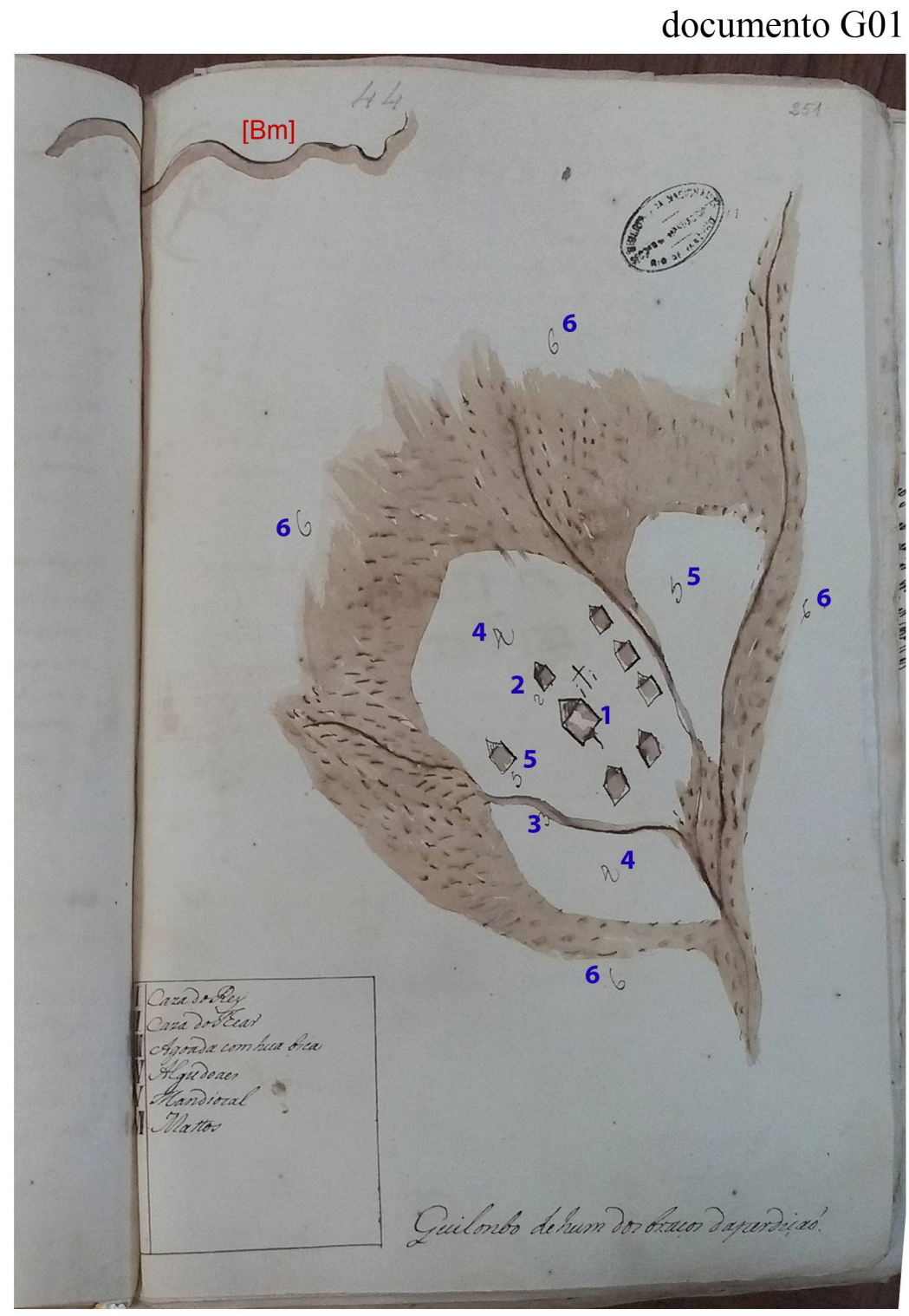

Quilonbo de hum dos braços da perdiçaõ. [1769?]. Papel. 2 folhas. Manuscrito. Português. Biblioteca Nacional, Rio de Janeiro, Coleção Ottoni, arquivo conde de Valadares, código: MS-575(1), folhas 250-251.

\section{Caza do Rey}

II Caza do Thear

III Agoada com hua bica

IV Algudoaes

$\mathrm{V}$ Mandiocal

VI Mattos 


\section{documento G02}

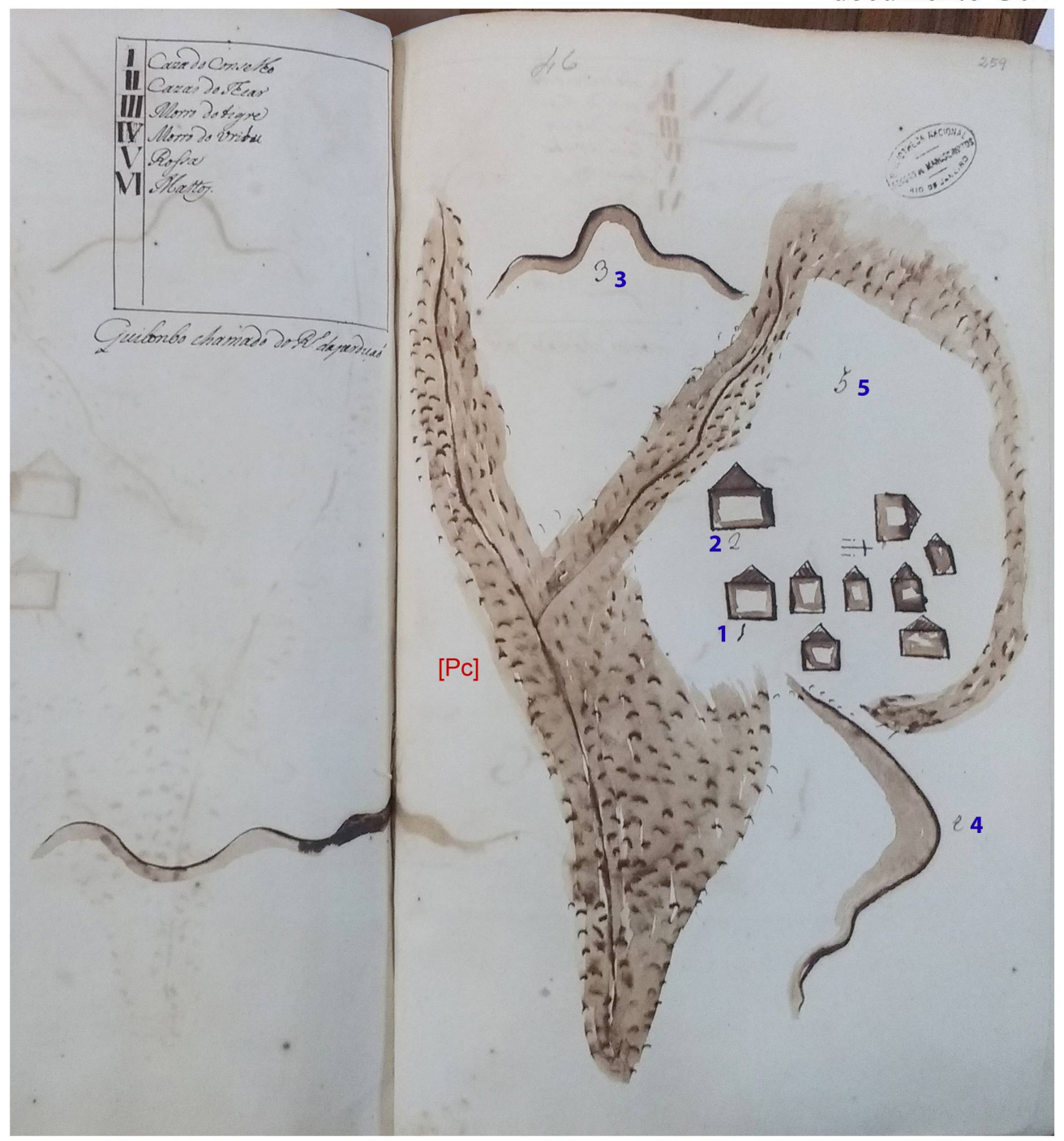

Quilonbo chamado do Rio da perdiçaõ. [1769?]. Papel. 2 folhas.

Manuscrito. Português. Biblioteca Nacional, Rio de Janeiro,

Coleção Ottoni, arquivo conde de Valadares, código: MS-575(1), folha 258-259.
I Caza do Conselho
II Cazas do Thear
III Morro do tigre
IV Morro do Uribu
V RoSsa
VI Mattos. 
documento G03

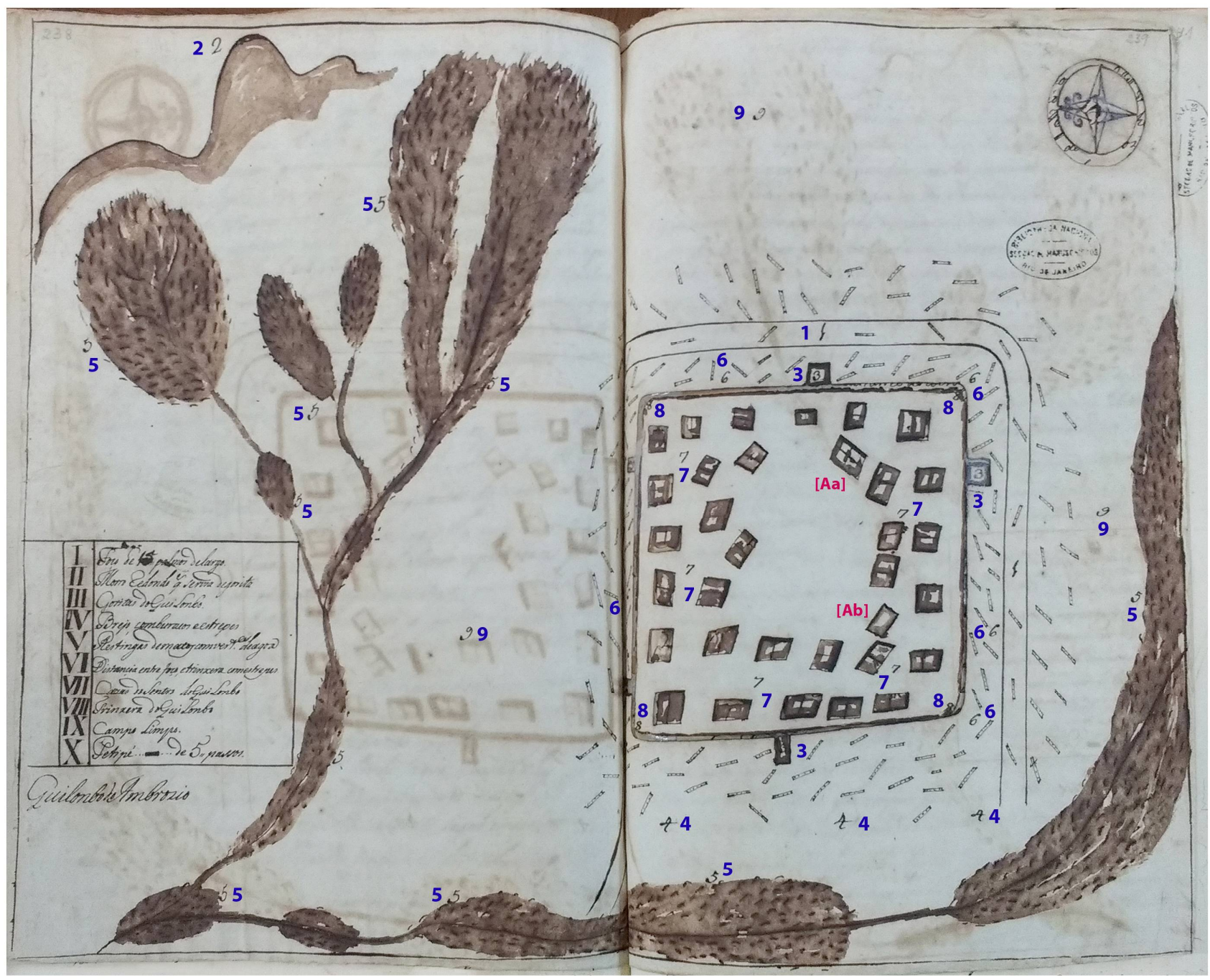

Quilonbo do Ambrozio. [1769?]. Papel. 2 folhas. Manuscrito. Português. Biblioteca Nacional, Rio de Janeiro, Coleção Ottoni, arquivo conde de Valadares, código: MS-575(1), folhas 238-239.

\footnotetext{
I Foço de 15// palmos de largo.

II Morro Redondo que servia de gorita

III Goritas do Quilonbo.

IV Brejo, com buracos e estrepes

$\mathrm{V}$ Restingas de matos com vertentes de agoa

VI Distançia entre foço, e trinxera com estrepes.

VII Cazas do Sentro do Quilonbo

VIII Trinxera do Quilonbo

IX Campo Limpo.

X Petipé ...[traço para medida de escala gráfica] de 5// passos.
} 
documento G04

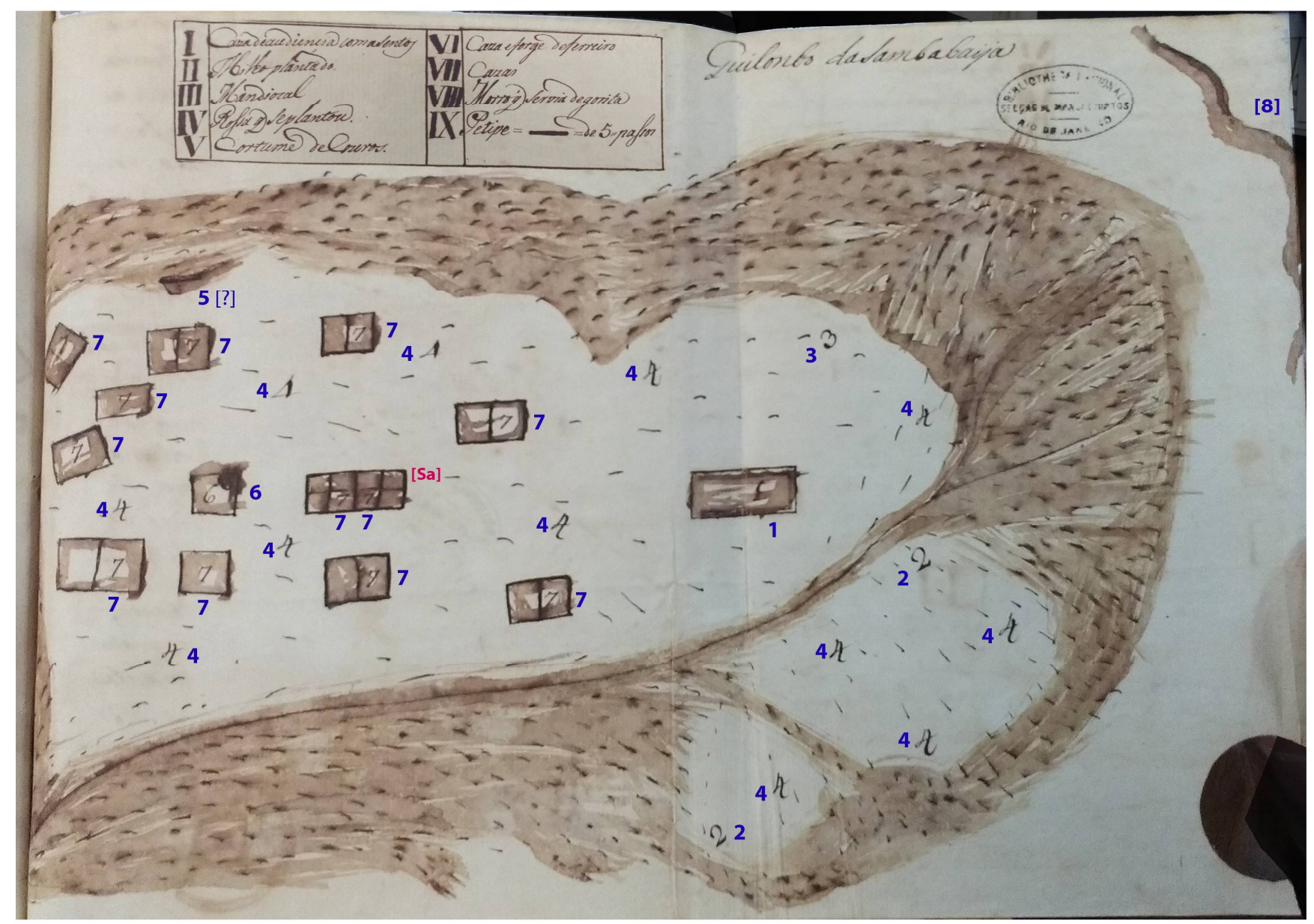

Quilonbo da Sambabaÿa. [1769?]. Papel. 1 folha. Manuscrito. Português. Biblioteca Nacional, Rio de Janeiro, Coleção Ottoni, arquivo conde de Valadares, código: MS-575(1), folha 243.

\begin{tabular}{lcl}
\hline I Caza de audiençia com aSentos & VI & Caza e forge de ferreiro \\
II Milho plantado. & VII & Cazas \\
III Mandiocal & VIII & Morro que servia de gorita \\
IV RoSia que se plantou. & IX & Petipe $=[$ traço para escala $]=5 / /$ paSsos \\
V Cortume de Couros. & & \\
\hline
\end{tabular}




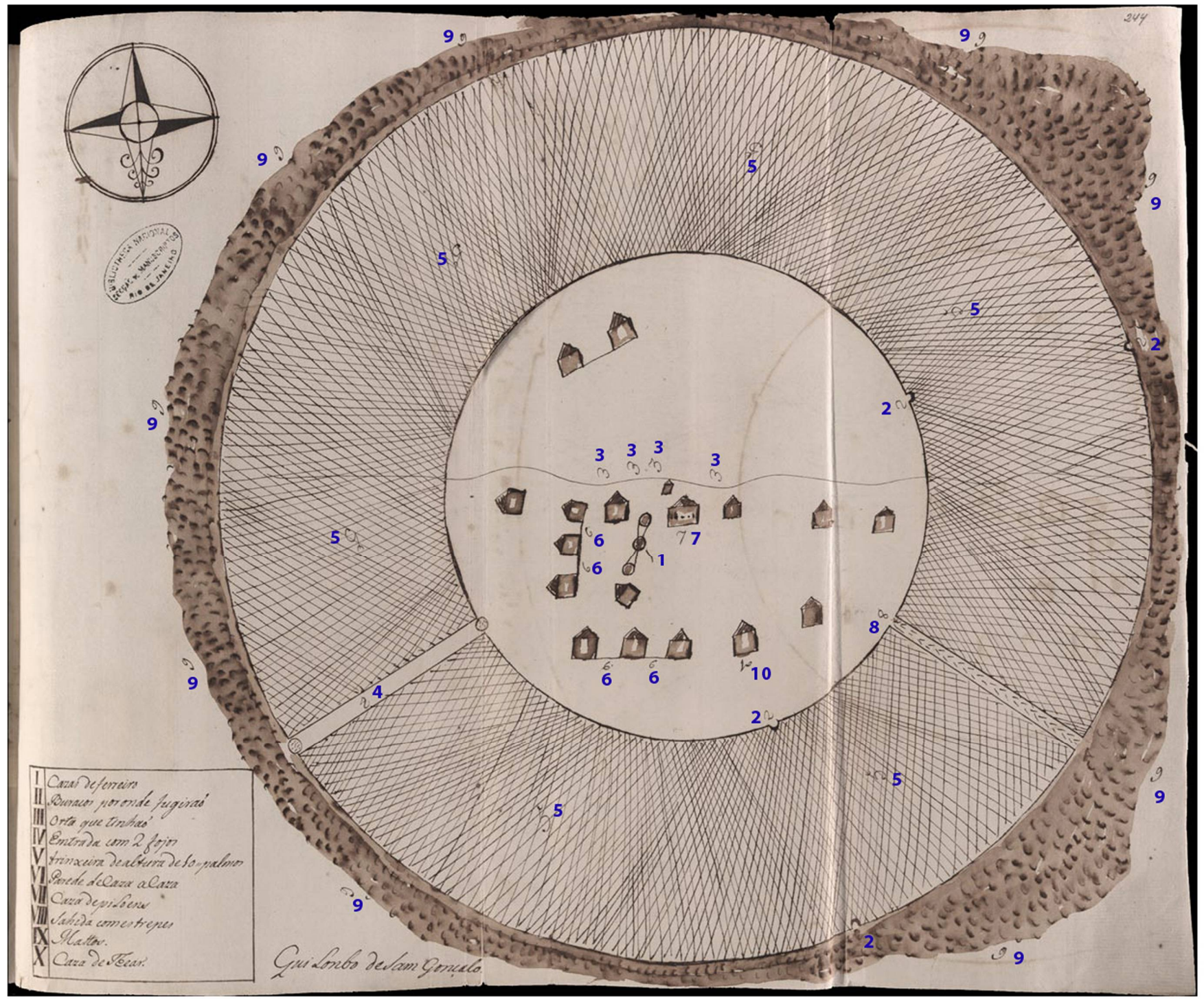

Quilonbo de Sam Gonçalo. [1769?]. Papel. 1 folha. Manuscrito. Português. Biblioteca Nacional, Rio de Janeiro, Coleção Ottoni, arquivo conde de Valadares, código: MS-575(1), folha 244.

I Cazas de ferreiro

II Buracos por onde fugiraõ

III Orta que tinhão

IV Entrada com 2 fojos

V trinxeira de altura de $10 / /$ palmos

VI Parede de Caza a Caza

VII Caza de piloens

VIII Sahida com estrepes

IX Mattos.

X Caza de Thear. 
documento G06

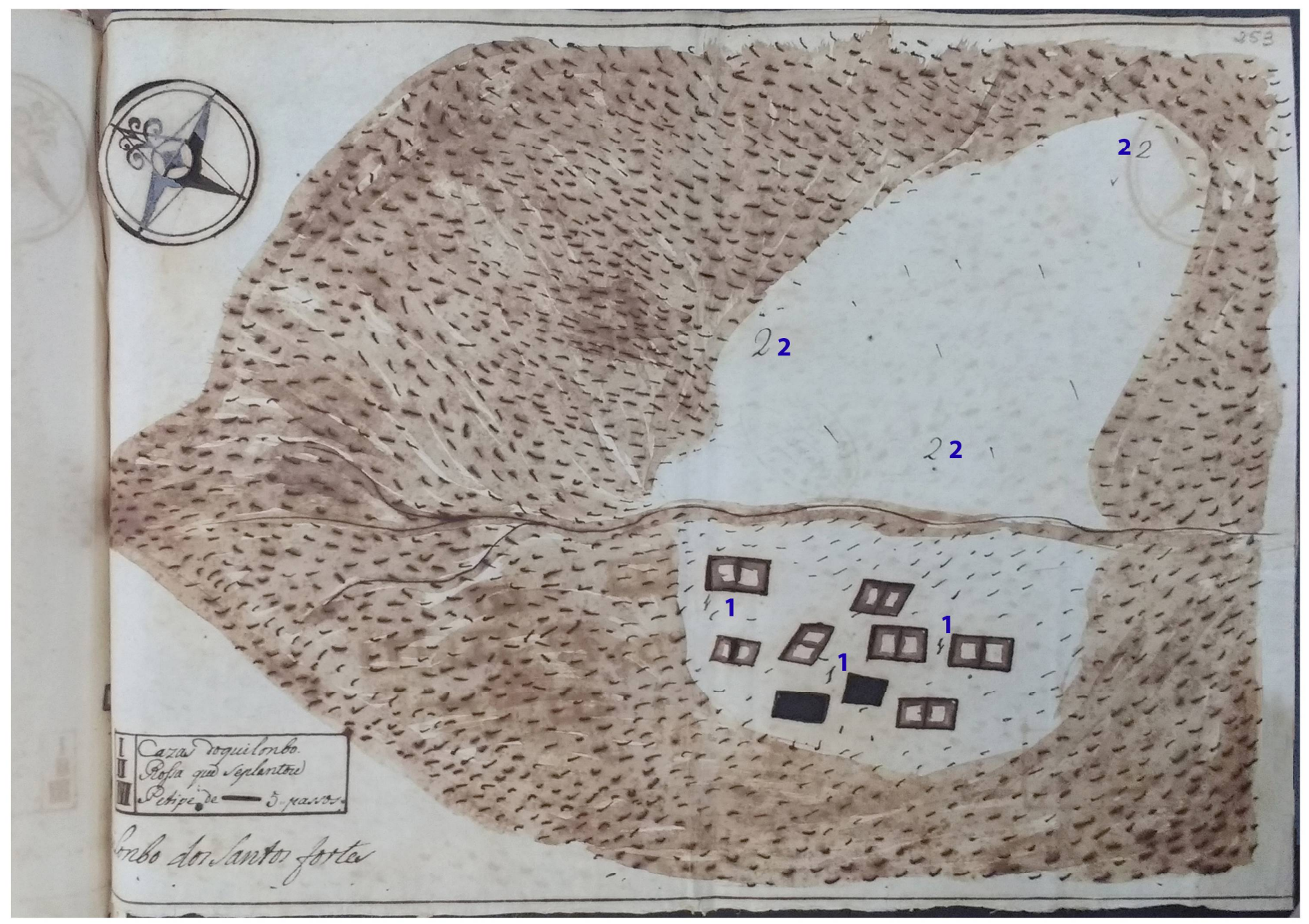

[Quilonbo] dos Santos fortes. [1769?]. Papel. 1 folha. Manuscrito. Português. Biblioteca Nacional, Rio de Janeiro, Coleção Ottoni, arquivo conde de Valadares, I Cazas do quilonbo. II RoSsa que se plantou

III Petipé de [traço para medida de escala gráfica] 5// passos. código: MS-575(1), folha 253. 


\section{3 - MAPA DE TODO O CAMPO GRANDE [...] [176-]}

O manuscrito intitulado "Mapa de todo o campo Grande tanto da parte da comquista, que parte com a Campanha do Rio verde, e S. Paulo, como de Piuhy cabeceyras do Rio de S. Francisco, e Goyazes" (doc. M03) integra a coleção J. F. de Almeida Prado do Instituto de Estudos Brasileiros da Universidade de São Paulo (IEB-USP).

O mapa foi executado sobre folha importada de trapo de algodão da D\&C Blauw, com textos e contornos das figuras em tinta ferrogálica. Para pigmentação dos desenhos foram utilizados dois tons de tintas cinza azulado, um mais claro e outro mais escuro, cujo efeito de transparência da pintura faz parecer que se trata de tinta aquarela. A alta qualidade do papel utilizado e os excelentes cuidados de preservação pelo IEB fazem com que, passados mais de dois séculos e meio desde sua produção, esse documento se mantenha em ótimo estado.

Tal manuscrito é constituído por uma folha única, onde há o desenho esquemático dessas regiões, acrescido de um título e um breve texto. Essa rica peça cartográfica pode servir de matéria para diferentes estudos que abordem tanto os assuntos por ela expostos, como sua composição iconográfica. Nesta pesquisa o "Mapa de todo o campo Grande [...]" é usado como contraponto ao relatório da expedição de Pamplona de 1769, uma vez que ambos tratam dessa região no mesmo período e circunstâncias.

Produzido em meados da década de 1760, esse documento apresentava para a administração pública portuguesa o resultado das expedições que, a seu serviço, exploraram a região do Campo Grande, buscando ouro, destruindo quilombos, construindo estradas e pontes para viabilizar o povoamento dessa zona com súditos da coroa ibérica.

O desenho retrata uma dilatada zona entre os rios Mogi-Guaçu, Pardo, Corumbá, Pernayba, São Francisco e serra da Mantiqueira, tendo o rio Grande ao centro. Nessas áreas

\footnotetext{
${ }^{1}$ Mapa de todo o campo Grande tanto da parte da comquista, que parte com a Campanha do Rio verde e S. Paulo como de Piuhy cabeceyras do Rio de S. Francisco, e Goyazes. [176-]. Papel. 1 mapa $89,5 \times 43 \mathrm{~cm}$. Manuscrito. Português. Arquivo IEB-USP, Coleção Yan de Almeida Prado, código: YAP023-016.

O manuscrito integra a coleção proveniente da biblioteca pessoal do historiador João Fernandes de Almeida Prado. Um breve histórico da chegada dessa coleção no IEB na década de 1960, assim como características do volume do qual foi extraído o mapa podem ser vistas em: HORCH, Rosemarie E. Relação dos manuscritos da coleção J. F. de Almeida Prado. Catálogo do Instituto de Estudos Brasileiros da Universidade de São Paulo, 1966. p.I-V p.55-58.
} 
foram localizados vinte e três núcleos quilombolas, alguns com o respectivo número de casas encontradas.

A análise paleográfica que fizemos para esse manuscrito, tanto do título e histórico das expedições (inserido no cartucho da lateral direta do documento), quanto dos textos do corpo do mapa (para os quais acrescentamos legenda), segue junto ao mapa editado (doc. M03). Buscando facilitar a leitura do documento, incluímos tal legenda também na transcrição do histórico da expedição, [entre colchetes].

\subsection{1 - Delimitação geográfica da zona do Campo Grande e expedições enviadas para sua conquista}

O "Mapa de todo o campo Grande tanto da parte da comquista, que parte com a Campanha do Rio verde, e S. Paulo, como de Piuhy cabeceyras do Rio de S. Francisco, e Goyazes" apresenta para a administração do Estado português o resultado da exploração dessas regiões por expedições militares.

No título temos a indicação das regiões tratadas pelo manuscrito: "campo Grande", "Rio verde”, "S. Paulo”, "Piuhy”, “cabeceyras do Rio de S. Francisco" e "Goyazes". O próprio mapa esclarece a abrangência dessas áreas. As cabeceiras do rio de São Francisco ${ }^{[32]} \mathrm{e}$ o rio do Piohy ${ }^{[33]}$ aparecem ao norte (na parte inferior da imagem), junto às serras da Canastra $^{[\mathrm{L}]}$ e da Marçela ${ }^{[\mathrm{m}]}$. O rio Verde ${ }^{[14]}$ nasce ao sudeste, no vale entre as serras do Ouro Fino $^{[\mathrm{a}]}$, da Mantiqueyra ${ }^{[\mathrm{b}]}$ e das Carrancas ${ }^{[\mathrm{c}]}$. A Campanha de São Paulo ${ }^{[126]}$ e Santa Anna de Goyazes $^{[129]}$ estão ao sudoeste e noroeste, sendo ligadas por uma longa estrada ${ }^{[125]}$.

Esses marcos geográficos delimitam o "campo Grande" como toda essa vasta zona próxima ao rio Grande ${ }^{[1]}$ (representado no centro do mapa), que estava relativamente distante dos focos de povoações luso-americanas em São Paulo ${ }^{[126]}$, Goyazes $^{[129]}$ e Minas Gerais ${ }^{[138]}$ (assinalados nas extremidades do desenho).

A relação dos produtores desse documento com a área retratada também foi indicada já no título: esse era um território em processo de "comquista" pelos expedicionários lusoamericanos que ali atuaram. A expressão "Campanha do Rio verde" pode dizer respeito às características físicas da paisagem natural ou se refere à forma de apropriação desse local, tomado através da atuação de campanhas militares. 
Inserido na lateral do manuscrito, o relato nos mostra que este era um documento destinado à administração pública portuguesa, a respeito de um empreendimento solicitado pela mesma. No início da inscrição, verificamos que o manuscrito foi produzido para ser entregue ao general Luís Diogo Lobo da Silva (governador da capitania de Minas Gerais entre dezembro de 1763 e julho de 1768), indicando o período de execução do documento. O mapa apresentava o resultado de explorações anteriores ao Campo Grande, que foram ordenadas pelo "conde de Bobedela”, título atribuído a Gomes Freire de Andrada ${ }^{2}$ em 1758 (que foi governador de Minas Gerais em três diferentes ocasiões, entre os anos de 1735 a 1736, de 1737 a 1752 e de 1758 até janeiro de 1763).

\subsection{2 - Expedições de Antonio Francisco França e de Bartolomeu Bueno do Prado entre 1756 e 1760}

A partir das informações apresentadas no "Mapa de todo o campo Grande [...]" verificamos que tal documento foi produzido por alguém que participou da expedição empreendida pelo capitão Antônio Francisco França. O historiador Waldemar Barbosa identificou tal capitão como um grande fazendeiro na região do Piuhy e nos "sertões da conquista", que teria fornecido mantimentos para a guerra contra os negros aquilombados do Campo Grande realizada em 1759, sob liderança de Bartolomeu Bueno do Prado ${ }^{3}$.

As realizações das campanhas de Bartolomeu Bueno e de Antônio Francisco França se tornaram matéria do "Mapa de todo o campo Grande [...]".

A narrativa informa que a "entrada" liderada pelo capitão França para "os çertoes das comquistas do Campo grande" teve como ponto de partida a povoação dos Buenos ${ }^{[101]}$, próxima ao arraial de Santa Anna das Lavras ${ }^{[102]}$ (ao sudeste do mapa), seguindo por terra na margem sul do rio Grande ${ }^{[1]}$ em direção à estrada de São Paulo para Goyazes ${ }^{[125]}$, atravessando o rio de Sapocahy ${ }^{[19]}$.

\footnotetext{
${ }^{2}$ A após a morte de Gomes Freire em 1763, a nomeação foi transmitida ao seu irmão, José Antônio Freire de Andrada (que também foi governador de Minas Gerais entre os anos de 1752 e 1758). A cronologia dos governadores da capitania nesse período pode ser vista em documento da época executado por: COELHO, José João Teixeira. Instrução para o governo da capitania de Minas [1780]. Transcrição e edição paleográfica por Cláudia Alves Melo. Belo Horizonte: Fundação João Pinheiro, Centro de Estudos Históricos e Culturais, 1994.

${ }^{3}$ BARBOSA, 1971, p.35-36; BARBOSA, 1972, p.41-47.
} 
O foco do relato escrito são os locais onde foram feitas experiências em busca de ouro. A expedição de França encontrou algumas tênues faíscas pela primeira vez na serra da Quadrilheira das Ezperanças ${ }^{[\mathrm{h} / \mathrm{i}]}$. Também foi achada faisqueira mais volumosa nas margens do rio Grande ${ }^{[1]}$ junto ao "descuberto de S. Pedro de Alcantra" [23], com extração de três quartos até uma oitava de ouro por semana.

A campanha do capitão Antônio Francisco França recuou quando, com a entrada das águas (possivelmente na estação de chuvas na primavera), muitos adoeceram de "Bexigas", saindo as gentes e "cavalgaduras" para o arraial de Santa Anna, na mesma região onde tinham começado a viagem. Os expedicionários embarcaram no Porto Real ${ }^{[104]}$ onde seguiram pelo rio Grande ${ }^{[1]}$ até as cabeceiras da serra das Ezperanças ${ }^{[\mathrm{k}]}$, onde encontraram ouro.

No relato foi destacado que a campanha de França destruiu um quilombo e deixou estradas e pontes sobre todos os cursos d'água que julgavam ser do Sapocahy ${ }^{[19]}$, adiante do Ribeirão das Araras ${ }^{[13]}$, que ficava a cerca de 50 léguas ${ }^{4}$ de distância da capital Vila Rica do Ouro Preto. O texto foi finalizado com a afirmação de que depois dessa diligência "se entrou a povoar com a gente" de São Paulo, Goyazes e Minas Gerais.

A narrativa fala também das experiências de ouro realizadas por Bartolomeu Bueno do Prado na cabeceira do rio das Velhas ${ }^{[31]}$ e de São Francisco ${ }^{[32]}$, onde em apenas dois córregos haviam encontrado faisqueiras de 4 a 6 vinténs ${ }^{5}$ por dia.

Segundo Waldemar Barbosa, documentos da administração da capitania de Mias Gerais descrevem que uma entrada comandada por Bartolomeu Bueno do Prado em 1756 encontrou faisqueira de ouro no rio das Velhas, ou das Abelhas, mas a exploração da jazida não era viável, devido à "insegurança" da região, pois era povoada por índios Kayapó e "negros aquilombados". Desde então foi preparada uma grande expedição para dominar o Campo Grande, financiada por câmaras de Minas Gerais, para a qual foram convocados índios Bororó como soldados das tropas luso-americanas.

\footnotetext{
${ }^{4}$ Como visto anteriormente, légua é uma medida de comprimento empregada na cartografia que, na América portuguesa, correspondia a 3.000 braças, ou o equivalente a 6.522 metros.Tomada por aproximação, uma légua corresponde a uma hora de caminhada a passo cheio. Ver: Bueno, 2007, loc. cit.; SANTOS, 2007, loc. cit.

${ }^{5}$ No sistema de unidades portuguesas, cada vintém correspondia a 1/32 oitavas de ouro, sendo usado como moeda naquele momento. $\mathrm{O}$ ouro era pesado em onças, sendo que $1 / 8$ de onça, conhecida por oitava de ouro, equivalia a 3,585 gramas.
} 
Tal campanha saiu em junho de 1759 de São João del Rei, sob liderança de Bartolomeu Bueno, com 400 homens (munidos com granadas, armas emprestadas, pólvora, chumbo, facões, tachos, mantimentos e botica), entre eles, capitães "experimentados", cirurgião, índios e "negros guias". Essa "guerra contra quilombos" foi encerrada em dezembro do mesmo ano de 1759, enviando os prisioneiros homens para às galés no Rio de Janeiro, enquanto as "negras" aprisionadas podiam ser restituídas aos proprietários mediante pagamento de taxa de tomadia. Em contrapartida, Bartolomeu Bueno recebeu o cargo de comandante do distrito de São Pedro de Alcantara e arredores e, obteve sesmaria entre o rio Lambari $^{[34]}$, serra das Ezperanças ${ }^{[i]}$, rio Grande ${ }^{[1]}$ e Pouso Alegre. ${ }^{6}$

\subsection{3 - Povoações e estradas}

A expedição de 1759 liderada por Bartolomeu Bueno do Prado teria sido responsável pela extinção do quilombo Grande, também conhecido por Ambrozio ${ }^{[136]}$, onde havia paióis cheios e roças plantadas, tendo os habitantes avistado as tropas antes de sua chegada e, assim, fugido. Os inimigos montaram guarda naquele povoado, caso algum quilombola viesse buscar mantimento e, dessa forma, capturaram algumas mulheres e crianças entre 4 a 12 anos de idade, nascidas no quilombo ${ }^{7}$. Assim, tomando pela idade das crianças nascidas ali, o Ambrozio estaria implantado naquele local pelo menos desde 1747.

Alguns dos quilombos que aparecem no "Mapa de todo o campo Grande [...]", provavelmente, são os mesmos que surgem no auto de posse para a capitania de Minas Gerais de 1759, referente aos territórios explorados pela expedição de Bartolomeu Bueno do Prado, com diferenças na grafia. Caso dos quilombos da Pernaiba ${ }^{[131]}$, do Creça ou Caregua ou Careca $^{[111]}$, do Bamboy ou Mammoi ${ }^{[135]}$, do Endaí ou Indaô ${ }^{[132]}$, do Morro do Angola ou Nova Angola ${ }^{[116]}$ (com 90 casas segundo o mapa M03), onde foram presos 25 "negros e crias, quase todos da nação Angola". ${ }^{.}$

Assim, o quilombo do Mammoi (com 150 casas) seria o quilombo do Bamboy, descrito nos relatos da campanha de Bueno como bem resguardado, com roças plantadas para o ano seguinte e paióis cheios. Seus moradores teriam enfrentado o ataque das tropas

\footnotetext{
${ }^{6}$ BARBOSA, 1972, p.43-53

${ }^{7}$ BARBOSA, 1972, p.48-50.

${ }^{8}$ BARBOSA, 1972, p.41-53.
} 
destruidoras, resultando em 59 presos (contando mulheres e crianças), poucos fugitivos e um grande número de quilombolas mortos, que tiveram o rio Bamboÿ por sepultura.

Na ilustração do mapa os destaques são o relevo, a hidrografia e os quilombos. Foram nomeados somente quatro arraiais (de Santa Anna das Lavras ${ }^{[102]}$, de Santa Anna ${ }^{[124]}$, de Sta. Anna de Goyazes ${ }^{[129]}$ e outro arraial com nome ilegível ${ }^{[127]}$ ), mais dois outros núcleos junto ao de Goyazes (o de Gurixaes ${ }^{[130]}$ e o "meya ponte" ${ }^{[128]}$ ). A mesma representação usada para essas povoações aparece entre o rio do Piohy ${ }^{[33]}$ e a serra das Ezperanças ${ }^{[\mathrm{k}]}$, local onde ficava o arraial de Piuhy. Já Minas Gerais ${ }^{[138]}$ e a Campanha de São Paulo ${ }^{[126]}$ tiveram apenas suas direções indicadas nas extremidade do desenho, assim como a povoação dos Buenos ${ }^{[101]}$. Portanto, esse documento apresenta um total de dez diferentes núcleos de povoamentos lusoamericanos implantados em toda a zona do Campo Grande e arredores.

No "Mapa de todo o campo Grande [....]" foram nomeadas apenas duas estradas: a de São Paulo para Goyazes ${ }^{[125]}$ (que ligava ambos os polos) e a "estrada por donde se fez a entrada para a comquista" ${ }^{[103]}$ (que começava próxima à povoação dos Buenos ${ }^{[101]}$, passava pelo quilombo da Boa Vista ${ }^{[108]}$ e ia até quilombo do Cascalho ${ }^{[110]}$ ), cuja execução foi ao menos parcialmente realizada pela expedição de França. Com a mesma tipologia de traçado dessas estradas, o desenhista fez a ligação entre uma série de quilombos próximos aos rios Pardo $^{[25]}$ e Sapucahy ${ }^{[19]}$. Esses caminhos poderiam ter sido abertos pelos quilombolas, conectando suas povoações, ou poderiam ser as rotas utilizadas pelas tropas destruidoras dos quilombos.

Escrito por um expedicionário da campanha de França, no texto há citação de apenas dois quilombos. Um deles era o quilombo "queymado chamamado a Boa Vista, já a tempos demolido" ${ }^{,[108]}$, situado entre o Rio Verde ${ }^{[14]}$ e o Rio Grande ${ }^{[1]}$, onde as tropas fizeram "Cituação", para procurar faisqueiras de ouro nos arredores. Outro era o quilombo do Cascalho $^{[110]}$, destruído pela campanha do capitão França.

Localizado nas cabeceiras do ribeirão da Conquista ${ }^{[21]}$ (curso d'água identificado como delimitador da faisqueira na margem oeste do rio Sapocahy ${ }^{[19]}$ ), o quilombo do Cascalho ${ }^{[110]}$ é assunto de um documento de 1760, que ordenava ao capitão Antonio Francisco França que entregasse para a câmara de São João del Rei as "negras e crias" capturadas por ele nesse quilombo ${ }^{9}$. Tais dados inferem que nesse povoado havia famílias cujas mulheres

\footnotetext{
${ }^{9}$ APM, cód.130, fl.49-50v analisado por: GUIMARÃES, 1999, p.88.
} 
eram fugitivas da escravidão, que estavam ali junto com seus filhos. O documento esclarece, também, que a expedição de França ocorreu no ano de 1760 ou pouco antes.

O padrão de identificação dos quilombos no mapa (circulando seus nomes e outras informações escritas) difere da representação dos povoamentos subordinados aos portugueses (com desenho de construções com cruzes ao topo). Na ilustração são assinaladas as localizações de vinte e três quilombos.

$\mathrm{Na}$ margem sul do rio Grande foram identificados dezesseis quilombos: um Quilombo $^{[105]}$ sem nomeação (despovoado), o quilombo do Gondu ${ }^{[106]}$ (com 80 casas), o quilombo do quebra $\mathrm{Su}^{[107]}$ (com 80 casas, despovoado), o Boa Vista ${ }^{[108]}$ (quilombo que foi destruído antes da chegada da expedição de França, sobre o qual o capitão fez "Cituação"), o quilombo do Cascalho ${ }^{[110]}$ (com 80 casas e conectado a um paiol ${ }^{[109]}$ ), o quilombo do Careca $^{[111]}$ (com 110 casas), o quilombo do Calaboca ${ }^{[112]}$ (com 70 casas), o quilombo do Zondú $^{[113]}$ (com 80 casas), o quilombo do Cacté e[114] $^{\text {(com } 90 \text { casas), o quilombo do Pinhaó }}{ }^{[115]}$ (com 200 casas), o quilombo da Nova Angola ${ }^{[116]}$ (com 90 casas), o quilombo da Boa vista ${ }^{[117]}$ (com 200 casas), o quilombo do Ooapeo ${ }^{[118]}$ (com 137 casas), o quilombo das Goaveyra ${ }^{\text {s[119] }}$ (com 90 casas, conectado a um canal de água de 1 légua de comprimento ${ }^{[120]}$ ), o quilombo das pedras $^{[121]}$, o quilombo do Fala ${ }^{[122]}$ (despovoado).

Na margem norte do rio Grande, próximo às nascentes do rio de São Francisco, foram assinalados quatro quilombos: a primeira povoação do Ambrozio $^{[137]}$ (despovoado), outro quilombo do Ambrozio ${ }^{[136]}$ (também despovoado), o S. Gonçalo ${ }^{[134]}$ (despovoado) e o quilombo do Mammoi ${ }^{[135]}$ (com 150 casas).

Entre os rios Pernayba e Corumbâ, foram representados mais três quilombos: o Ajuda $^{[133]}$ (despovoado), o quilombo do Indaô $^{[132]}$ (com 200 casas) e o quilombo do Pernaiba $^{[131]}$ (com 70 casas).

Entre os quilombos assinalados no "Mapa de todo o campo Grande [....]", a destruição de apenas um foi atribuída às tropas do capitão França. Os demais quilombos foram demolidos pela expedição de Bartolomeu Bueno do Prado, citada no documento, ou por outras campanhas militares. 


\subsection{4 - Meios de manutenção dos quilombos}

Mesmo que o "Mapa de todo o campo Grande [....]" não apresente maiores detalhes sobre a configuração e funcionamento dos quilombos, nem sequer possua indicação de escala ou outra medida das áreas desses povoados, a leitura do mapa nos permite algumas conjecturas a respeito dos mesmos.

Entre os elementos encontrados no desenho, sublinhamos o "Rego de Agoa que tinha huá Legoa de comprido" ${ }^{,[120]}$, que ligava afluentes do rio Pardo ao quilombo das Goaveyras $^{[119]}$. Entendemos que esse seria um canal construído pelos quilombolas para abastecer o povoado. A execução desse canal aquífero de 1 légua de comprimento (cerca de $6,5 \mathrm{~km}$ ) demandaria o trabalho de um considerável número de pessoas, o que implicaria uma boa organização por parte dos quilombolas.

Já o paiol ${ }^{[109]}$, que na ilustração está conectado ao quilombo do Cascalho ${ }^{[110]}$, deveria armazenar a produção do último (provavelmente de alimentos) e se localizava na margem oposta do rio da Conquista. Através desse par (quilombo e paiol instalado a certa distância do povoado) podemos supor que as terras de cultivo e armazenamento de alimentos ou outras estruturas desses quilombos excedessem os locais pontuados no desenho. Assim, a representação que circula os nomes e número de casas dos quilombos, talvez, se referisse às áreas onde estavam concentradas as habitações, enquanto o território dominado por esses povoados fossem maiores ou, talvez, vários dos quilombos individualmente nomeados fossem núcleos de habitações relacionados a outros vizinhos, constituindo comunidades mais complexas.

É notável a grande quantidade de casas atribuídas aos quilombos nesse registro. Não encontramos documentos que especificasse o número de habitantes de cada quilombo. Contudo, especulando que cada construção abrigaria uma família com no mínimo três pessoas (com um casal com um filho, por exemplo), o quilombo do Cascalho abrigaria ao menos 240 pessoas nas 80 casas. Seguindo o mesmo critério, o quilombo do Careca, teria aproximadamente 660 pessoas em suas 220 casas.

No entanto, esses números são apenas conjecturas, necessitando de mais dados para se chegar a um raciocínio bem embasado sobre a população dos quilombos. Muitas dimensões poderiam ser exploradas a partir da analise do "Mapa de todo o campo Grande [...]", confrontado com outras fontes que abordem os elementos nele citados. Novos trabalhos 
dedicados a esse documento colaborariam para compreensão das características de cada um dos povoados quilombolas indicados no manuscrito, ou da movimentação do povoamento dessa zona por escravizados fugidos, agentes lusitanos ou mesmo por indígenas, ou das formas de conflitos entre esses grupos pelo domínio desses territórios, entre outros. Todavia, o desenvolvimento de muitas dessas questões era inviável no tempo desta pesquisa.

Independentemente do número preciso de moradores em cada casa, o sustento desses populosos quilombos demandaria uma farta oferta de alimentos, visto que nos menores deles foram assinaladas 70 casas.

A oferta abundante de água pela farta rede hidrográfica da região (incluindo a construção de canais d'água) poderia ser um facilitador do estabelecimento dos numerosos quilombos citados no documento. O registro dos paióis e roças infere que ao menos parte desses quilombos possuíam cultivo e armazenamento de alimentos para sua própria manutenção.

Alguns quilombos que estivessem próximos de jazidas de ouro podiam se dedicar à exploração desse metal, trocando tais produtos por mantimentos ou armas ${ }^{10}$.

\subsection{5 - Considerações ao Mapa de todo o campo Grande [...]}

O "Mapa de todo o campo Grande [....]" registra os quilombos encontrados nessa região entre as fronteiras das capitanias de S. Paulo, Minas Gerais e Goyazes que, em meados do século XVIII, passava por um processo de conquista pelo Estado português. Esse documento iconográfico nos oferece pistas sobre as conformações espaciais e geográficas dos povoados quilombolas abatidos.

Nos chama atenção a decisão do capitão Antônio Francisco França de fazer "Cituação" sobre o sítio do antigo quilombo da Boa Vista ${ }^{[108]}$, talvez por este local apresentar alguma vantagem geográfica. As tropas de França arrancharam sobre as cinzas do povoado, para dali seguir para destruir o quilombo do Cascalho, construindo sua estrada para a conquista $^{[103]}$ sobre as ruínas de ambos os povoados quilombolas demolidos.

Nesta aproximação com o "Mapa de todo o campo Grande [...]” vemos que, segundo o documento, a expedição do capitão Antonio Francisco França buscava novos locais para

\footnotetext{
${ }^{10}$ GUIMARÃES, 1996, p.143.
} 
mineração ao mesmo tempo em que se dedicava à destruição de quilombos e à abertura de estradas e pontes sobre rios e córregos para facilitação do povoamento dessas áreas. Em outras palavras, a mesma campanha tinha atribuição de encontrar riquezas, expulsar os habitantes quilombolas daqueles locais e viabilizar o "povoar com a gente" subordinada à coroa portuguesa no novo território conquistado.

Os poucos arraiais e estradas ilustradas nesse documento contrastam com os numerosos quilombos, com dezenas ou centenas de casas cada um. Explorando esse mapa, fica a impressão de que, até aquele momento, a região entre os núcleos coloniais de São Paulo, Minas e Goyazes estava menos sob domínio da coroa portuguesa do que de povoações não subordinadas a ela.

Observando o "Mapa de todo o campo Grande [...]" em confronto com análises das campanhas nele descritas, constatamos que as expedições ali empreendidas tinham como objetivo declarado o arrasamento dos quilombos e a procura de novas jazidas. Assim como os memorialistas de Pamplona, os relatores da campanha de França, ao apresentar suas realizações para os governadores da capitania de Minas Gerais, destacaram a construção de estradas e ranchos para tropas sobre quilombos arrasados e se vangloriaram de que a atuação de suas expedições militares facilitou o povoamento das áreas exploradas por súditos lusitanos. 
documento M03 - Mapa de todo o campo Grande tanto da parte da comquista, que parte com a Campanha do Rio verde, e S. Paulo, como de Piuhy cabeceyras do Rio de S. Francisco, e Goyazes. [176-]

\section{EDIÇÃO DO TEXTO NA LATERAL DIREITA DO MAPA DE TODO O CAMPO GRANDE}

Mapa de todo o

campo Grande tanto da parte da

comquista, que parte com a Campanha do

Rio verde, e S. Paulo, como de Piuhy cabe-

ceyras do Rio de S. Francisco, e Goyazes.

Na entrada que se fes para os

çertoes das comquistas do Campo grande por Ordem do $\mathrm{Ill}^{\text {mo }}$.

$S^{r}$. conde de Bobedela como se ordenou ao capp ${ }^{\text {am }}$. Antonio Francisco

França o qual agora poem na presença do Ill $^{\text {mo }}$ e Ex ${ }^{\text {mo }} \overline{S n r} G^{\text {nal }}$ Luis

Diogo Lobo da Silva como dito $S^{r}$ ordena, o seguido.

Sahimos da Pavoacão dos Buenos ${ }^{[101]}$ ao Arrayal de $S^{\text {ta }}$.

Anna das Lavras ${ }^{[102]}$ que Sáo Cratro Legoas, donde se proçeguio a via gé por terra entre o Rio Grande ${ }^{[1]}$, e Rio verde ${ }^{[14]}$, em partes tem de distançia de hú a outro de 25 // té 30 Legoas. Primeiramente se passarão dous Ribeyrotes grandes chamados o Servo ${ }^{[7]}$, em Ru mo direito a Serra das tres pontas ${ }^{[\mathrm{g}]}$, te chegar ao Quilombo quey mado chamado a Boa Vista ${ }^{[108]}$, já a tempos demolido o qual estava cituado entre o Rio Verde $e^{[14]}$, e Rio grande ${ }^{[1]}$ co mo se mostra no titulo do mapa; e em todos os mais daqueles continentes; e fazendoçe experiencia de Ouro em toda aquela campanha não mostrou couza algúa, e somente pegado a Serra da Quadrilheir $\underline{a}^{[\mathrm{h}]}$ das esperanças mostrou algúas tenuas faíscas cuja deligência proceguio o capp $^{a m}$. Antonio Francisco França, emquanto se foi destruhir o Quilombo chamado o do Cascalho ${ }^{[110]}$ ' $q$ se achava nas Cabeceiras do Ribeirão da Comquista ${ }^{[21]}$, o qual he delimitada faisqueira para sima da Outra banda de Sapo cahy ${ }^{[19]}$ fica os Ribeiroes do Cabo Verde ${ }^{[15]}$, c agoas claras $^{[16]}$, adonde hoje he o discuberto chamado do Ezpindola ${ }^{[15]}$, e para as cabeceiras do Rio das Velhas $^{[31]}$, e de S. Francisco ${ }^{[32]}$ havia feito o Cappitão Bartolomeu Bueno do Prado algúas experiencias, em 'q achou faisqueira de jornal de 4 vinteis té seis vinteis por dia em dous corgos somente e por Respeito de entrarem 'as agoas, e adoecer muita gen te de Bexigas sahimos para fora com toda a gente, e cavalgaduras para o a Rayal de $S^{\text {ta }}$. Anna ${ }^{[102 ? / 124 ?]}$ deyxando estradas, e pontes em todos os Rios, e Corgos 'q se julga ser do Rio Sapocahy ${ }^{[19]}$, q fica adiante do Ribeirão das Araras ${ }^{[13]}$ te a capital de Vila Rica do Ouro Preto 50 Legoas pouco mais ou menos embarcando[?] nós no Porto Real ${ }^{[104]}$, abaxo de $S^{\text {ta }}$. Anna ${ }^{[102]}$ pelo Rio grande. ${ }^{[1]}$ abaxo te as Caxoeiras das Ezperanças ${ }^{[\mathrm{i}]}$ donde se fes varias experiencias de Ouro, e no Rio em alguás em taypabas [?] por ja hir cheyo se achou alguás [faisqueiras] de ouro porem nas Gopiaras, 'q vertem ao Rí Grande. ${ }^{[1]}$ principalmente para o Certão, em 'q hoje se acha o descuberto de S. Pedro de Alcantra ${ }^{[23]}$,e aprovando-se, em varias partes se achou faisqueira de tres Coartos, te oita va por semana e nas marges do dito Rio $\mathrm{gr}^{\text {de }} .{ }^{[1]}$ se fes alguá expe riencia, e se achou ser de te novas[?] faisqueiras; e como depois desta deligência se entrou a povoar com a gente, 'q comcorreo[?] de S. Paulo ${ }^{[126]}$, e Goya $z{ }^{[130]}{ }^{2}$ e destas Geraes ${ }^{[138]}$, em 'q já esta Caresma próxima povada se dez obrigarão mil e cem pessoas pouco mais ou menos. 


\begin{tabular}{|c|c|c|}
\hline \multicolumn{3}{|c|}{ Legendas acrescidas à imagem do Mapa de todo o campo Grande - CURSOS D'ÁGUA } \\
\hline 1 - Rio Grande & 14 - Cabeceyras do Rio Verde & 27 - Rio de Iagoari [?] \\
\hline 2 - Ingahy / todo Capivari & 15- discoberto chamado o do & 28 - Rio da Itibaya \\
\hline 3 - Corgo dos tabudes [?] & Ezpindola Cabo Verde & 29 - Rio de Carumbâ \\
\hline 4 - Ribeirão de Sta. Ana das & 16 - agoas claras & 30 - Rio de Pernayba \\
\hline Lavras & 17 - Rio muzambo & 31 - Rio das Velhas \\
\hline 5 - Ribeirote de agoa Limpa & 18 - tupixé & 32 - Cabeceyras do Rio de S. \\
\hline 6 - Ribeirão de Fr. João & 19 - Rio de [Sapocahy] & Francisco \\
\hline 7 - Rio do Servo & 20 - Barra de Sapocahy & 33 - Rio do Piohy \\
\hline 8 - Ribeirão do Couro do Servo & 21 - Rio da conquista & 34 - Rio Lambari \\
\hline 9 - Lagoa & 22 - S. João & 35 - Ribeirote \\
\hline 10 - Reaxo das tres pontas & 23 - S. Pedro de Alcantra & 36 - Rio Grande pequeno \\
\hline 11 - Ribeirão verde & 24 - todo Jacuhy & 37 - Rio [Jacaré] \\
\hline 12 - Reaxo & 25 - Rio Pardo & 38 - Rio das Mortes \\
\hline 13 - Ribeirão das Araras & 26-Rio Moji á Sû & \\
\hline
\end{tabular}

Legendas acrescidas à imagem do Mapa de todo o campo Grande - POVOAÇÕES, ESTRADAS E OUTROS

\begin{tabular}{|c|c|}
\hline 101 - Pavoação dos Buenos & 120 - Rego de Agoa 'q tinha huá Legoa de \\
\hline 102-Arrayal de Sta. Anna das lavras & comprido \\
\hline 103 - estrada por donde se fez a entrada para a & 121 - Quilombo das pedras \\
\hline comquista & 122 - Quilombo o Fala dezpovoado \\
\hline 104 - Porto Real & 123 - desemboque \\
\hline 105 - Quilombo despovoado & 124 - Arrayal de Sta. Anna \\
\hline 106 - Quilombo do Gondu cazas 80 & 125 - estrada de S. Paulo para Goyazes \\
\hline 107 - Quilombo do quebra Sû cazas despov. 80 & 126 - Campanha de S. Paulo \\
\hline 108 - Boa Vista adonde se fez a Cituação o capitão & 127 - Arrayal de Sta. [ilegivel] \\
\hline França & 128 - meya ponte \\
\hline 109-Payol & 129 - Sta. Anna de Goyazes \\
\hline 110 - Quilombo do Cascalho prese . [?] cazas 80 & $130-$ Gurixaes \\
\hline 111 - Quilombo do Careca [?] cazas 220 & 131 - Quilombo da Pernaiba cazas 70 [?] \\
\hline 112 - Quilombo do Calaboca cazas 70 & 132 - Quilombo do Indaô cazas 200 \\
\hline 113 - Quilombo do Zondú cazas 80 & 133 - Ajuda despovoado \\
\hline 114 - Quilombo do Cacté cazas 90 & 134 - S. Goncalo despovoado \\
\hline 115 - Quilombo do Pinhaó cazas 200 [?] & 135 - Quilombo do Mammoi cazas 150 \\
\hline 116-Quilombo da Nova Angola cazas 90 & 136 - Quilombo do Ambrozio despovoado \\
\hline 117 - Quilombo da Boa vista cazas 200 & 137 - Prim $^{a}$. Povoação do Ambrozio \\
\hline 118 - Quilombo do OOареo [?] cazas 137 & despovoados \\
\hline 119 - Quilombo das Goaveyras cazas 90 & 138 - Minas Gerais \\
\hline
\end{tabular}

Legendas acrescidas à imagem do Mapa de todo o campo Grande - RELEVO

\begin{tabular}{lll}
\hline a-Serra do Ouro Fino & e-Itacolomi & $j$-Ponta da Serra das \\
b-Serra da Mantiqueyra & - Serra de Pedro & Carrancas \\
c-Serra das Carrancas & Francisco[?] & $k$-Serra das Ezperanças \\
d- Morro mais alto q tem todo o & g-Serra das tres pontas & L-Serra da Canastra \\
Certão e chamado o & $h$-Coadrilheyra & $m$-Serra da Marçela \\
Bertururo Sû [?] & $i$-Serra das Ezperanças &
\end{tabular}




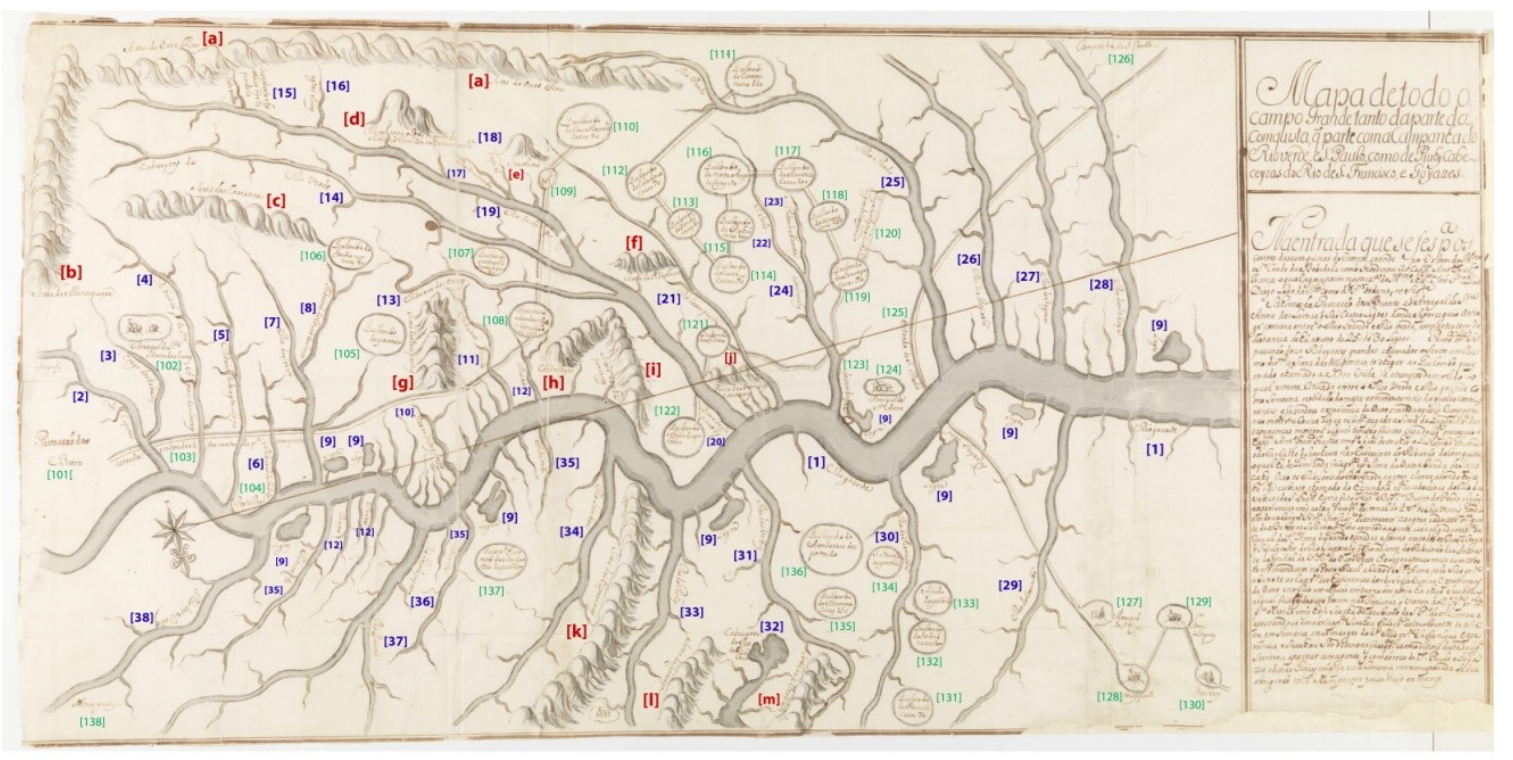

Mapa de todo o campo Grande tanto da parte da comquista, que parte com a Campanha do Rio verde, e S. Paulo, como de Piuhy cabeceyras do Rio de S. Francisco, e Goyazes. [176-]. Papel. 1 mapa, 89,5×43cm. Manuscrito. Português. Arquivo IEB-USP, Coleção Yan de Almeida Prado, código: YAP-023-016. 


\section{4 - CARTAS DA ADMINISTRAÇÃO PÚBLICA DA CAPITANIA DE MINAS GERAIS}

No acervo do Arquivo Nacional selecionamos duas cartas do governador da capitania de Minas Gerais que tratam do combate aos quilombos em meados do século XVIII, servindo de comparativo aos documentos iconográficos analisados.

Uma é a carta do governador Gomes Freire destinada ao vice-rei, de outubro de 1746 (AN cod.84, vol. 11, fl.164v - fl.165v). A correspondência informava que uma campanha militar com 400 homens foi enviada para combater os "negros aQuilombados" que atacavam os moradores da comarca do Rio das Mortes. A expedição atacou um quilombo fortificado com 2 estacadas e 1 fosso com estrepes. As tropas tiveram atacá-lo por duas vezes, pois os "negros se defendião com mais furor do que se entendeu ultimamente", usando granadas para cortar a segunda estacada. Dentro do quilombo as tropas encontraram 106 quilombolas armados com dardos, flechas e umas poucas espingardas. Ao fim do combate contaram 32 quilombolas mortos, mais de 70 homens rendidos, além dos "pequenos e negras", contra 22 soldados luso-americanos feridos.

Segundo a carta, esse quilombo estava instalado na região da comarca cujo nome derivava do curso d'água onde estava implantada, o rio das Mortes ${ }^{[38]}$, afluente do rio Grande, que aparece no "Mapa de todo o campo Grande [...]" (M03). Tomando pela data da carta, talvez o quilombo destruído em 1746 relatado na carta se refira à primeira povoação do Ambrozio $^{[137]}$, identificado desse mapa.

Pela descrição vemos que aquele era um quilombo populoso e longevo o bastante para abrigar famílias com crianças, cuja estrutura de defesa era suficiente para dificultar invasão dos inimigos luso-americanos. As fortificações descritas na carta de 1746 lembram as retratadas pela expedição de Pamplona para o quilombo do Ambrozio (doc.G03) que, segundo nossa analise, deve ter sido destruído em 1759. Se esse foi o caso, depois de destruído o primeiro quilombo do Ambrozio ${ }^{[137]}$, outro Ambrozio $^{[43}$ ou 74 ou 136] similar ao primeiro foi reerguido mais adiante, na margem ocidental das cabeceiras do rio de São Francisco, por indivíduos que escaparam do ataque de 1746 ou por outros grupos quilombolas.

A segunda carta selecionada é também de autoria do governador Gomes Freire, o conde de Bobadella, destinada ao secretário de Estado da Marinha e Ultramar, Tomé Joaquim da Costa Corte Real, datada de 1759 (AN cod.80, vol.9, fl.105-105v). Nela foi descrita a destruição de quilombos localizados entre as capitanias de Goiás e Minas Gerais. O escrito 
fala de três ou quatro quilombos que eram subordinados a um quilombo maior "donde residia a negra Corte, e o chamado Rey a que os mais obedecião". Todos esses quilombos foram destruídos por tropas luso-americanas, prendendo 50 homens e 50 "negras", sem contar o número de mortos.

Essa carta de 1759 aponta novamente para a existência de quilombos com grande número de habitantes nessa zona de fronteiras entre as capitanias auríferas, que contava com homens e mulheres. Esse documento reafirma a formação de uma rede quilombola complexa e hierarquizada nessa região, com líderes que eram chamados de "Rey" por seus inimigos, nesse caso agregado a uma corte real. Alegando a formação de uma realeza, com séquito e quilombos subordinados a eles, que rivalizaria com o poder do Estado português, os agentes lusitanos justificariam a destruição desses povoados. Também é possível que a titulação de realeza fosse atribuída aos seus líderes pelos próprios quilombolas.

Adiante apresentamos a edição paleográfica de ambas as cartas. 


\section{Carta de Gomes Freire para o vice-Rei de 1746}

Arquivo Nacional - Secretaria de Estado do Brasil - Códice 84 (cópia do códice 83)

Correspondência dos governadores do Rio de Janeiro com autoridades (1718-1763) / Livro 11 anos de 1743 até 1749 (cod.84, vol. 11, fl.164v - fl.165v)

Para o Vice-Rey

$\mathrm{IIl}^{\mathrm{mo}} / / \mathrm{e} \mathrm{Ex}{ }^{\mathrm{mo}}$ Snor. Não obstante o grande embaraço que o tempo causava a expedição da frota, e estou persuadido a que estas embarcações não a encontrão já em esse [?] porto, sempre repito a minha obediencia às ordens de V.Ex ${ }^{\mathrm{a}}$. A frota desta Capitania sahio a barra o dia 16: Deos lhe de feliz viagem, pois creyo não vai menos importante este, que o passado anno. _ Insultando os negros aQuilombados com desmedidos atrevimentos os moradores da Comarca do Rio das mortes, resolvi mandalos atacar em suas fortificações; armei quatrocentos homens, que continuão na deligencia, havendo já conseguido extinguir o primeiro que encontrarão outro armado de duas estacadas, e hum fôço, semeado de estrépes duas vezes fora os rechaçados; pois os negros se defendião com mais furor do que se entendeu ultimamente, foi entrada a segunda estacada sendo cortada a favor das nossas Granadas, e hé certo sem ellas seria mais difficil, e estavão dentro cento e seis negros de armas poucas espingardas, tudo dardos, e flechas, morrerão no conflicto trinta e dous negros, ficarão rendidos settenta e tantos, não contando pequenos e negras; a tropa vai continuando a marcha pelas noticias, que encontra bom será tenha a mesma felicidade com os outros: dos nossos soldados ficarão feridos vinte e dous; mas não haverá risco de vida com mais de dous. $\S \_$No mais tudo gosa tranquilidade, e eu estou prompto no serviço de V.Ex ${ }^{\mathrm{a}}$. Deos guarde a V.Ex ${ }^{\text {a }}$ muitos// annos. Rio de Janeiro 23 de Outubro de 1746. Ill $^{\mathrm{mo}}$ e $\mathrm{Ex}^{\mathrm{mo}} / /$ Snor. Vice-Rey do Estado// Gomes Freire $/ /$ de Andrada. 
Carta do Conde de Bobadella para Tomé Joaquim da Costa Corte Real de 1759

Arquivo Nacional - Secretaria de Estado do Brasil - Códice 80- vol.09 -

Correspondência ativa e passiva dos governadores nos anos de 1750-1752 / 1759-

1761(cod.80, vol.9, fl.105-105v)

$<$ Menezes $>$

De Janr. [?] 16 de Dezembro de 1759//

Ill. ${ }^{\mathrm{mo}}$ e Ex. ${ }^{\mathrm{mo}} \mathrm{S}$. Tomé Joaquim da Costa Corte Real//

Conde de Bobadella

Sobre se haverem destruido tres,

ou quatro quilombos de negros nas

Minas Geraes.

$\mathrm{Ill}^{\mathrm{mo}}$. Ex. ${ }^{\mathrm{mo}} \mathrm{S}^{\mathrm{r}}$. Estando essa Náo Levando ancora

para se ir por em franquia, recebo aviso de Josephe Antonio

Freire de Andrada de que felizmente se havião destruido os Quilombos, que erão tres, ou quatro, alguns delles ja na

Capitania de Goyás, todos subordinados a hum Mayor, donde residia a negra Corte, e o chamado Rey a que os mais obedecião. Ainda me não dá inteira conta, nem refere o numero dos mortos, se foi, que entre elles acabára o chamado Rey, e que vierão cincoenta prezos, e cincoenta negras; e visto que estas não tenhão culpa, mando se entreguem a seos donos com hum donativo, que as Camaras determinarem á [beneficio] dos homens, que tantos meses trabalharão, e os cincoenta negros the declaro mos mande, pois ficando e sem legal prova em breve se irão livrando. Eu os mando meter na Fortaleza de Villagalhon [?], a qual precisa de trabalho de hum grande desmonte:/ vem a bom tempo/

$\mathrm{V}$. Ex ${ }^{\mathrm{a}}$. medirá, não se provando com a legalidade, que os Jurîstas pedem, | impoSivel em Minas, e desertos| o que devo praticar com estes cincoenta negros.

A Camara da Cidade Marianna me fez a Carta da Copia junta, a qual posto, que firmada em Novembro, a esta hora a Recebo, e me pareceo remettella por aSim o dar providencias, que remede e ouso em que os negros estão de se aquilombarem / ainda os [ilegível] bem tratados/ neceSita providencia.

Sobre o que prepoem de animar os descobridores, não poSo discorrer ao presente, na frota repetirei o que me socorrer [?] para V. Exa ${ }^{\text {a }}$ o pôr na Real prezença. Deos [guarde] a V. Ex ${ }^{\text {a }}$. Rio de Janeiro $16 \mathrm{de}$ Dezembro? de $1759_{/ /} \mathrm{Ill}^{\mathrm{mo}}$. Ex ${ }^{\mathrm{mo}} \mathrm{S}$. Tome [Joaquim] da Coroa Corte Real// Conde de Bobadella 


\section{5 - TRADUÇÃO DOS MAPAS HISTÓRICOS PARA CARTOGRAFIA ATUAL}

Visto que cada peça cartográfica analisada possui uma proporção diferente das demais, criamos um mapa unificado que traduz parte das informações dos documentos para uma linguagem mais familiar aos nossos dias.

Pela facilidade de acesso, confiabilidade e qualidade dos materiais, adotamos os mapas físicos fornecidos pelo Instituto Brasileiro de Geografia e Estatística (IBGE) ${ }^{11}$ como base de trabalho. Sobre tais bases destacamos a hidrografia e relevo que aparecem nos documentos analisados. Boa parte dos rios e povoados luso-americanos identificados nos documentos ainda hoje são conhecidos por nomes similares.

Confrontando os mapas históricos com as bases cartográficas atuais, percebemos que há distorções nas escalas dos desenhos. Porém, mesmo com as imprecisões dos documentos iconográficos, a partir dos cursos d'água, serras e outros elementos atualmente reconhecíveis, é possível ter uma boa ideia das regiões onde estariam implantados os quilombos representados. A rede hidrográfica abundante dessa zona possibilita restringir as variáveis dos locais onde poderiam estar os antigos povoados quilombolas: entre um e outro rio, entre essa e aquela serra. Apenas os três quilombos entre os atuais rios Paranaíba e Corumbá tem sua posição mais incerta, visto que o documento onde eles são apresentados não oferece maior detalhamento desses locais.

Interpretando as cartografias históricas abordadas e transpondo a localização dos quilombos do Campo Grande nelas apresentadas para um desenho unificado, o mapa contemporâneo torna as informações dos documentos mais legíveis aos nossos olhos, figurando entre os destaques do trabalho desta pesquisa.

Produzindo tal mapa, pudemos confrontar as fontes primárias e verificar, por exemplo, que certos quilombos que aparecem com nomes similares em diferentes documentos, podem realmente se referir aos mesmos povoados.

\footnotetext{
${ }^{11}$ Fundação Instituto Brasileiro de Geografia e Estatística - IBGE. Cartas e mapas. Disponíveis em: $<$ https://portaldemapas.ibge.gov.br/portal.php\#homepage>. Acesso em jun.2019.
} 


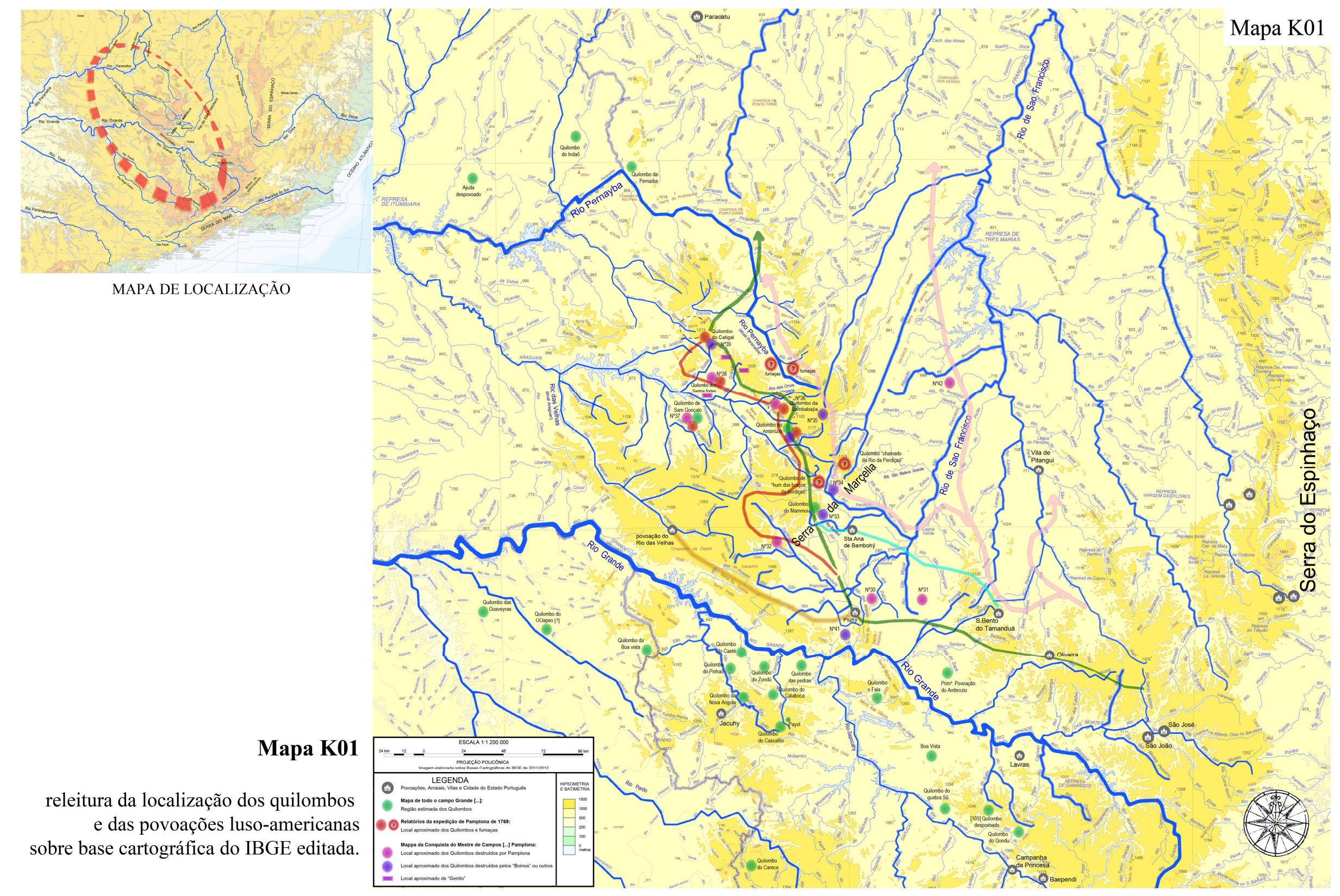




\section{Capítulo 3 - QUILOMBOS E DISPUTAS TERRITORIAIS NO CAMPO GRANDE NO SÉCULO XVIII}

Nesse capítulo realizamos o cruzamento das fontes primárias selecionadas para elaboração do corpo central da pesquisa (apresentadas no capítulo 2), analisando as informações delas extraídas com o auxílio de outros registros da época, de bibliografia relacionada e do mapa atual que construímos para unificar os dados extraídos das cartografias históricas.

A partir das fontes, discutiremos as características dos quilombos estudados, a localização desses povoados, a importância do combate dos quilombos para os agentes lusoamericanos, a apropriação de espaços quilombolas para implantação da estrutura colonial do Estado português, entre outros.

\section{1- DEFINIÇÃO DE “QUILOMBO" E "NEGROS” SEGUNDO OS DOCUMENTOS OFICIAIS DAS REGIÕES MINERADORAS NO SÉCULO XVIII}

\subsection{1 - Quem são os “Negros"}

Nos relatos da campanha de Pamplona de 1769 (os mais volumosos entre os documentos estudados) os habitantes dos quilombos foram chamados de "Negros", "negros aquilombados" ou "calhambolas". Nos mesmos textos, também são chamados de "Negros", de "escravo" ou de "bom preto" aqueles que eram tratados como propriedade de agentes lusitanos. A divisão da sociedade local foi evidenciada em certo evento, em que Pamplona foi procurado para resolver questões sobre terras e justiça, quando o relator descreveu a presença de pessoas "brancas", "mais pardagem e Negraria em quantidade", onde os últimos provavelmente eram escravizados dos primeiros ${ }^{1}$. Sendo assim, entendemos que, nesses documentos, "Negros" é uma categoria relacionada à cor de pele e também à passagem pela condição de escravizados.

Dessa maneira, quando os relatores dos documentos da expedição de 1769 se referiram aos quilombolas como "Negros", eles estavam presumindo que esses eram pretos de ascendência africana, fugitivos do cativeiro. No entanto, tal hipótese dos expedicionários nem sempre foi confirmada pelos mesmos, já que a grande maioria dos quilombolas fugia antes da chegada das tropas.

\footnotetext{
${ }^{1}$ ANBNRJ, 1988, p.58-60/ p.64.
} 
Visto que nas regiões auríferas vizinhas predominava a escravização de africanos e descendentes, os fugitivos das áreas mineradoras que se refugiavam nos sertões do Campo Grande deveriam constituir boa parte dos moradores desses povoados quilombolas. A população autóctone dessa região tinha sofrido decréscimo devido à caça e escravização pelos bandeirantes. No entanto, alguns índios Kaiapó ainda se mantinham nessas partes ${ }^{2}$. Desse modo, é possível que africanos e ameríndios estivessem ali misturados, sendo que, nos quilombos de maior longevidade nasciam novas gerações, que podiam ser de mestiços desses povos. Os quilombos podiam eventualmente abrigar também alguns luso-americanos livres fugidos da justiça ou afins. No entanto, a associação aos quilombolas era arriscada devido à agressividade dos agentes portugueses contra os mesmos. Assim a presença desses indivíduos nos quilombos devia ser restrita.

Poucos são os relatos oficiais que oferecem maiores informações sobre as pessoas que habitavam os quilombos, sendo difícil confirmar as composições populacionais dos mesmos.

\subsection{2 - 0 que são “Quilombos”}

O termo "Quilombo" (habitualmente usado com letra maiúscula naquele momento) era usado para se referir aos ajuntamentos de fugitivos pelos documentos públicos da administração portuguesa na América, que tratam da região das minas auríferas no XVIII. Nas fontes trabalhadas não encontramos a palavra "mocambo" para especificá-los, por isso não empregamos tal substantivo para se referir aos povoados estudados. ${ }^{3}$

Ao longo dos anos, houve modificações quanto ao número mínimo de habitantes e tipos de equipamentos existentes que eram necessários para que tais ajuntamentos fossem considerados "Quilombos" pelo Estado português. O regimento de capitães do mato de 1722 definia "Quilombo" como um reduto de escravizados fugidos, com ao menos 4 pessoas, instalados a alguma distância dos povoados luso-americanos, que tivessem "ranchos e pilões e modo de ali se conservarem".

2 VENÂNCIO, Renato Pinto. Antes de Minas: fronteiras coloniais e populações indígenas. In: RESENDE; VILlALTA (org.). As Minas Setecentistas, vol.1. Belo Horizonte: Autêntica; Companhia do Tempo, 2007. p.87-102.

${ }^{3}$ MOCAMBO; QUILOMBO. In: MOURA, 2004, p.277/ p.335-339; GOMES, Flávio dos Santos. Quilombos/ Remanescentes de Quilombos. In: SCHWARCZ; GOMES (org.). Dicionário da escravidão e liberdade: 50 textos críticos. São Paulo: Companhia das Letras, 2018. p.367-373. 
A palavra "Quilombo" foi difundida a partir de 1740, quando uma carta do rei de Portugal ao Conselho Ultramarino o redefiniu como "toda habitação de negros fugidos que passem de cinco, em parte desprovida, ainda que não tenham ranchos levantados nem se achem pilões neles". 4

Sendo assim, uma única família de fugitivos ou um pequeno grupo de rebeldes que se estabelecesse fora dos domínios do Estado português poderiam ser chamados de quilombolas e, portanto, combatidos como tal.

A diferença legislativa apontada acima se concentra, sobretudo, nos "ranchos" e "pilões". Nos anos de 1720 era necessário que houvesse plantio e beneficiamento de alimentos para que as aglomerações fossem consideradas quilombos. Segundo a ordem régia, a partir da década de 1740, a existência de meios de subsistência dos habitantes no local onde estavam instalados era indiferente, podendo qualquer ajuntamento de fugitivos, mesmo que temporário, ser considerado um quilombo. Considerados ilegais, esses povoados podiam sofrer ataques por agentes lusitanos, estivessem eles organizados em grandes tropas oficiais aparelhadas pelo Estado português ou fossem alguns poucos homens do mato em busca de recompensas pela captura de fugitivos.

A legislação luso-americana justificava os assassinatos de quilombolas pelos repressores em caso de reação desses. Segundo a ordem régia de 1741, o prêmio pago aos capitães do mato por calhambola capturado era superior àquele pago pelos que fossem mortos. No entanto, em ambos os casos os enfrentamentos eram remunerados. Uma das formas de certificação do combate aos quilombos pelos capitães do mato, para que recebessem seus pagamentos, era a entrega dos corpos dos calhambolas para as autoridades. Os rebeldes mortos eram desmembrados e suas cabeças ou orelhas eram salgadas para retardar a decomposição e, então, tais partes de seus cadáveres eram transportadas até o destino final. Assim, as cabeças ou orelhas dos inimigos se tornavam um tipo de moeda de circulação restrita. O castigo exemplar marcado nos corpos dos rebeldes era uma prática institucional recorrente no absolutismo. Assim, a exposição das cabeças de quilombolas em locais públicos, onde todos pudessem ver as consequências de suas transgressões à ordem

\footnotetext{
${ }^{4}$ GUIMARÃES, Carlos Magno. Quilombos, classes, estado e cotidiano: Minas Gerais, século XVIII. 1999 f. Tese (Doutorado em História) - Faculdade de Filosofia, Letras e Ciências Humanas da Universidade de São Paulo, São Paulo. p.191-196.
} 
instituída, era um dos sádicos atos do espetáculo de divulgação do poder do Estado colonial português. ${ }^{5}$

Vemos, portanto, que são os agentes lusitanos que compreendem esses ajuntamentos como "quilombos" e seus habitantes como "negros aquilombados". Os próprios moradores dos povoados quilombolas da região poderiam se compreender como parte de um único grupo ou, ao contrário, certos quilombos poderiam rivalizar com outros ajuntamentos quilombolas vizinhos.

Como nossa visão sobre os quilombos é intermediada pelos olhos de seus inimigos, é difícil saber como aqueles quilombolas entediam a si mesmo ou quais eram as relações entre os povoados da região. No entanto, mesmo que nossos meios disponíveis não sejam os ideais, é possível buscar pistas sobre o funcionamento de tais povoações nos documentos oficiais do Estado português que dispomos.

Desejando adentrar o interior desses quilombos extintos, nos detivemos, sobretudo, em seus registros executados pela campanha de Pamplona de 1769, confrontando-os com outros documentos da época e com o estudo arqueológico do Ambrozio.

A partir dessas fontes, procuramos entender os tipos de ajuntamentos documentados. Seriam compostos de uns poucos indivíduos rebeldes que, sem meios próprios de subsistência, viveriam do assalto em estrada, arraiais e fazendas, como se queixavam as autoridades luso-americanas ${ }^{6}$ ? Ou tais ajuntamentos eram populosos e bem estruturados, com "ranchos e pilões e modo de ali se conservarem"? Quais seriam as características arquitetônicas e espaciais daqueles quilombos? Existiria uma rede de solidariedade que conectasse os quilombos da região, ou cada aglomeração era independente e estranha às suas vizinhas? Perseguiremos tais questões adiante.

\footnotetext{
${ }^{5}$ BARBOSA, Waldemar de Almeida. Negros e quilombos em Minas Gerais. Belo Horizonte: 1972. p.72-73; SOUZA, Laura de Mello e. Norma e conflito: aspectos da História de Minas no século XVIII. Belo Horizonte: Ed. UFMG, 1999. p.98; GUIMARÃES, 1999, p.248-253.

${ }^{6}$ Ver cartas dos governadores da capitania de Minas Gerais sobre os "perniciosos estragos" causados pelos negros dos quilombos em: GUIMARÃES, 1999, p.258-298.
} 


\section{2 - ARQUEOLOGIA DO AMBROZIO}

A fama do quilombo do Ambrozio foi tamanha que sua memória se manteve por séculos depois de destruído. Devido à permanência de seu nome nos topônimos, nos registros de terras da região e no conhecimento popular local, foi possível localizar suas ruínas em pleno século XX.

As publicações dos resultados parciais das escavações, iniciadas em 1987, tornam possível um diferente tipo de aproximação à organização espacial, características das construções e regime alimentar praticado no extinto quilombo do Ambrozio. ${ }^{7}$

O levantamento arqueológico identificou o núcleo habitável do povoado, delimitado por vestígio de fosso em forma de ferradura, que possuía área aproximada de $15.000 \mathrm{~m}^{2}$, com mata e córrego fechando sua extremidade norte. Como vimos na análise do desenho executado pela expedição de 1769 , tomando as medidas através da escala gráfica, o fosso que protegia as construções do Ambrozio abrangia uma área de cerca de $15.625 \mathrm{~m}^{2}$, segundo a imagem. A constatação de similaridades entre o desenho e o estudo arqueológico infere uma boa confiabilidade à escala gráfica e às características físicas do povoado apresentada na ilustração do Ambrozio, credibilidade que porventura foi empregada nos demais desenhos dos quilombos realizados por tal campanha militar.

Os vestígios de incêndio, encontrados pelos trabalhos de escavação, constituem o marco da morte do quilombo. Até a data da publicação do levantamento arqueológico (que estava em andamento na época), foram encontrados resquícios alimentares em apenas uma das construções, o que pode significar a concentração do preparo ou armazenamento de alimentos em uma edificação especializada.

Nas escavações dos quilombos do Ambrozio e da Cabaça foram descobertos fragmentos de ferro fundido, chapas metal, tiras estanho, panelas, caldeirões, chaleira, colher, pote e objetos reparados com rebites.

Nas ruínas arqueológicas do Ambrozio foram identificados fragmentos carbonizados de postes de madeira fincados no chão, junto com restos de troncos, blocos de barro cru com

\footnotetext{
${ }^{7}$ GUIMARÃES, Carlos Magno; LANNA, Ana Lúcia Duarte. Arqueologia de quilombos em Minas Gerais. Pesquisas: Antropologia, São Leopoldo, v.31, p.147-167, 1980;

GUIMARÃES, Carlos Magno; CARDOSO, Juliana. Arqueologia do quilombo: Arquitetura, Alimentação e Arte (Minas Gerais). In: MOURA (org.). Os quilombos na dinâmica social do Brasil. Alagoas: EDUFAL, 2001. p.35-58.
} 
marcas de dedos e de madeira, resquícios de piso alisado ao brilho e sem pedregulhos. Não foi encontrado no local qualquer fragmento de telha cerâmica. Tais destroços indicam que as construções possuíam estrutura em madeira, paredes com trama de paus a pique vedadas com barro, cobertura com material de origem vegetal (como folhas de palmeiras) e piso em terra batida. O uso da taipa de mão foi comum nas construções populares por séculos, sendo algumas delas objeto de diferentes estudos, como abordaremos adiante. 


\section{3 - POSSÍVEIS ARQUITETURAS DOS QUILOMBOS DO CAMPO GRANDE NO SÉCULO XVIII}

\subsection{1 - Construções em madeira "a pique" e barro}

Construções rústicas em madeira eram comumente encontradas no atual território brasileiro até o início do século XX. Na década de 1930, os modernistas Gilberto Freyre e Lucio $\operatorname{Costa}^{8}$ se dedicaram à observação de habitações populares, considerada primitiva ${ }^{9}$ por eles, para inspirar a fundação de um novo código estético e social ${ }^{10}$. Naquele momento, Freyre liderou um estudo que analisava essas residências elementares, produzindo ilustrações das mesmas (fig.01). Tais tipologias construtivas foram amplamente difundidas por séculos, sendo também adotada em alguns quilombos.

Essas construções eram executadas com estruturas de troncos de madeira, conhecidas como "pau a pique". Esse consiste de paus, geralmente roliços e com casca (de diâmetro entre 15 e $20 \mathrm{~cm}$ ), fincados perpendicularmente entre os baldrames e frechais, com espaçamento médio de um palmo entre eles. Para constituir as paredes, horizontalmente são colocadas varas ou ripas mais finas, amarradas com cipó, fibras vegetais, couro ou pregos (fig.02). Para vedação dos vãos da trama das paredes, essa armadura de madeira pode ser preenchida com barro, posto com as mãos. Esse conjunto de barro e madeira é nomeado como "taipa de mão", que pode ser usada para construção de paredes externas ou divisões internas, sendo uma obra

${ }^{8}$ COSTA, Lucio. Documentação Necessária. Revista do Serviço do Patrimônio Histórico e Artístico Nacional, Rio de Janeiro, n.1, p.31-39, 1937; FREYRE, Gilberto. Mucambos do Nordeste: Algumas notas sobre o tipo de casa popular mais primitiva do nordeste do Brasil. Rio de Janeiro, SPHAN, s.d. [1937].

9 Nesse caso, o termo "primitivo" está relacionado à noção de origem primeira. Não está necessariamente atrelado ao desdobramento evolucionista do conceito de primitivo como contraposição ao civilizado. $\mathrm{O}$ homem primitivo e sua edificação primeira são pontos de referências constantes na teoria arquitetônica de diferentes povos e épocas, sendo convocados quando há desejo de renovação de paradigmas ou quando se buscam reformas de práticas corrompidas. Ver: RYKWERT, Joseph. A casa de Adão no paraíso: A idéia da cabana primitiva na História da Arquitetura. São Paulo: Perspectiva, 2009.

${ }^{10}$ Sobre as disputas travadas na época a respeito da manutenção ou extinção dos mocambos, comuns no Recife na primeira metade do século XX, ver: LIRA, José Tavares Correia. "A construção discursiva da casa popular no Recife (década de 30)". Revista Análise Social, vol. XXIX (127), p.733753, 1994; Quanto ao projeto modernista de inserção da arte brasileira no contexto internacional, ver: CHUVA, Márcia. Fundando a nação: a representação de um Brasil barroco, moderno e civilizado. Revista Topoi. Rio de Janeiro, v.4, n.7, p.313-333, jul/dez, 2003. 
econômica e de rápida execução. Tais materiais são suscetíveis à umidade advinda do solo e das chuvas, caso estejam expostos à água. ${ }^{11}$

No trabalho de Lemos e Corona a técnica construtiva onde a terra umedecida é agregada a uma estrutura de madeira foi chamada de "taipa de mão", "de sebe" ou "de sopapo”. Quando publicam seu dicionário de arquitetura na década de 1970, a taipa de mão sem trabalhos de carpintaria sofisticados ou emprego de madeiras de lei, era usada por lavradores que não dispunham de meios ou aprimoramento técnico. Assim, segundo tais autores, o pau a pique encontrado em casas roceiras e mucambos era indicativo da "transitoriedade das obras". ${ }^{12}$

Em sua pesquisa, Antônio Luiz de Andrade também reconhece maior sobrevivência da técnica de pau a pique em fins do século XX nas construções populares nas periferias urbanas e nas áreas rurais, às quais intitula "Arquitetura Vernacular". Nelas os baldrames, quando existem, geralmente são apoiados diretamente sobre o solo (sem alicerce) e raras são as peças de madeira aparelhadas, sendo utilizadas com sua sessão natural. Os telhados (cobertos por palha ou telha de barro) utilizam tesouras ou caibros armados, descarregando os esforços sobre as vigas e esteios de madeira (fig.03). Nessa arquitetura vernacular, os materiais construtivos eram extraídos do ambiente e a construção era feita pelo próprio morador, com auxílio de seus vizinhos. ${ }^{13}$

Apesar de seu rareamento, essas casas compactas de poucos ambientes, executadas artesanalmente a partir de materiais naturais extraídos do entorno, herdeiras de conhecimentos técnicos heterogêneos, ainda no início do século XXI apresentam exemplares habitados ${ }^{14}$.

\footnotetext{
${ }^{11}$ VASCONCELLOS, Sylvio C. de. Arquitetura no Brasil - sistemas construtivos. Belo Horizonte: Escola de Arquitetura UFMG, 1958.

12 TAIPA. In: CORONA, Eduardo \& LEMOS, Carlos A. C. Dicionário da Arquitetura brasileira. São Paulo: Edart, 1972. p. 437-439

13 ANDRADE, Antonio Luiz Dias de. Vale do Paraiba, sistemas construtivos. 1984 f. Dissertação (Mestrado em arquitetura) - Faculdade de Arquitetura e Urbanismo da Universidade de São Paulo, São Paulo.

${ }^{14}$ A técnica contemporânea do pau a pique, para construção e manutenção de edificações de comunidades rurais quilombolas, pode ser visto nos documentários a respeito do Vale do Ribeira ver:

TAIPA DE MÃO, CASA DE CABLOCO. Direção de Luiz Bargamann. São Paulo: Faculdade de Arquitetura e Urbanismo da Universidade de São Paulo, 1998. 19', português, colorido. Disponível em: <https://vimeo.com/51696268>. Acesso em: mar.2018;

TAIPA NO ESTADO DE SÃO PAULO. Direção de Lia Marcia Marinho. São Paulo: Ministério da Cultura, Secretaria do Audiovisual, Instituto Marlin Azul e Petrobras, 2008. 14', português, colorido. Disponível em: <https://www.youtube.com/watch?v=qnQKaN86LmI > . Acesso em: mar.2018.
} 


\subsection{2 - Tipologias de moradias afro-americanas}

Como exemplos de moradias afro-americanas, destacamos três imagens que representam tais habitações, produzidas na primeira metade do século XIX.

Uma é a litografia "Habitação de negros" (fig. 04), produzida em 1835 a partir do desenho de Johann Moritz Rugendas - artista bávaro que entre 1822 e 1825 percorreu regiões de Minas Gerais, São Paulo, Rio de Janeiro, Salvador e Recife. Na imagem, a adoção da taipa de mão no exterior da construção foi evidenciada pelo desenho de textura das paredes. Tomando as proporções das pessoas na composição, a construção deve medir cerca de 2x3 metros em planta, com não mais que 3 metros de altura até a cumeeira. A cobertura de duas águas parece ser constituída por algum tipo de folha de palmeira. No desenho da habitação há apenas uma abertura visível, usada como porta de acesso, não muito mais alta ou larga que a pessoa sob o vão.

Tal casebre representado por Rugendas exemplifica o que foi chamado de "senzalabarraco" pelo historiador Robert Slenes ${ }^{15}$. Esse tipo de construção pequena, com volume independente de outras, que comportaria uma única família de escravizados, foi também registrada em uma aquarela de 1817 (fig.05) de Thomas Ender (austríaco que percorreu territórios luso-americanos como integrante da expedição científica que também contou com os naturalistas Johann von Spix e Carl von Martius) ${ }^{16}$.

Outra tipologia de habitação foi ilustrada pela litografia "Senzalas" (fig.06), publicada em 1859, de autoria de Victor Frond (artista francês exilado no Brasil na época de Napoleão III). A construção apresentada possui planta retangular com telhado cerâmico de quatro águas que se prolonga na lateral recobrindo também um trecho externo. Sem presença de janelas frontais, o corpo principal da edificação conta com três portas com esteios verticais entre elas e nas extremidades, acrescido de mais um cômodo em sequência com porta mais baixa e pé-

\footnotetext{
${ }^{15}$ Em sua pesquisa sobre famílias escravas no sudeste no século XIX, Slenes trata das habitações dos cativos a partir de iconografia e relatos de viajantes ou membros das elites nacionais. Tendo usado as litografias aqui apresentadas, o autor recorre às descrições do livro de Rugendas e de Charles Ribeyrolles, companheiro de exílio de Frond, cujo texto é ilustrado pelas imagens do último. Ver: SLENES, Robert W. Na senzala uma flor: esperanças e recordações na formação da família escrava, Brasil Sudeste, século XIX. Rio de Janeiro: Nova Fronteira, 1999. p.131-236.

${ }^{16}$ Aquarela de Thomas Ender de 1817, analisada por: MARQUESE, Rafael de Bivar. Moradia escrava na era do trafico ilegal: senzalas rurais no Brasil e em Cuba, c. 1830-1860. Anais do Museu Paulista, São Paulo: v.13, n.2, p.165-188, Jul - Dez. 2005.
} 
direito acompanhando a caída do telhado. Os vãos entre os esteios de madeira parecem ter menos de 2 metros de largura, com o corpo da construção totalizando cerca de 8 metros de comprimento, com cerca de 3 metros de altura na fachada sob o beiral da cobertura. Essa tipologia pode ser chamada de "compartimento/cabana", caracterizado pelo agrupamento de alguns pequenos cômodos, cada um deles podendo abrigar uma família ou grupo.

A "senzala-pavilhão" seria uma construção de maior porte, formada por uma série de cômodos dispostos em linha. Um exemplo desse tipo de habitação pode ser visto em outra litografia de Victor Frond (fig.07).

Segundo o historiador, diferentes tipologias construtivas poderiam ser encontradas em uma só fazenda, ficando os solteiros prioritariamente em senzalas-pavilhão, com construções separadas para homens e mulheres, enquanto os casais escravizados prefeririam usar senzalasbarraco.

Sobre os materiais e volumetria das habitações, Slenes apresenta também o relato do viajante inglês Robert Walsh:

"As choças eram muito toscas, feitas com paus e cobertas com folhas de palmeira, e seu teto era tão baixo que só no centro dela [sic] uma pessoa conseguia manter-se perfeitamente ereta. Um tabique feito de vime trançado dividia as choupanas em dois cômodos (...); uma porta de taquara trançada vedava a entrada." 17

Robert Slenes vê nesses registros de habitações de escravizados formas de manifestações de algumas liberdades na execução das próprias moradias pelos cativos, feitas de acordo com seus padrões culturais e organizações familiares, reconhecendo similaridades entre essas senzalas com construções da África subsaariana. Semelhanças essas que seriam justificadas se considerarmos o quão recente era a presença desses indivíduos na América. A partir de recenseamentos da época, o historiador afirma que $80 \%$ dos escravos adultos das regiões da grande lavoura no Rio de Janeiro, São Paulo e da agropecuária mais dinâmica de Minas Gerais eram africanos, sendo os demais majoritariamente filhos dos mesmos.

As semelhanças entre as "senzalas-pavilhão" brasileiras com construções africanas foram apontadas também no ensaio de Günter Weimer ${ }^{18}$. Segundo o autor, os aldeamentos do

\footnotetext{
${ }^{17}$ Robert Walsh. In:SLENES, op.cit., p.160.

${ }^{18}$ WEIMER, Günter. Arquitetura Popular Brasileira. S.Paulo: WMF Martins Fontes, 2005.p.128-147.
} 
povo Fangue (de origem bantu, que povoam a fronteira entre Gabão, Guiné Equatorial e Camarões na África Ocidental), são ordenados linearmente em duas filas de casas retangulares geminadas de $3 \times 4$ metros cada, sem presença de janelas, unidas sob cobertura contínua de duas águas de folhas de palmeiras, formando grandes edifícios conhecidos por "Sanzalas", também encontradas no norte de Angola.

Segundo esses autores, as construções comumente encontradas na África Central e Ocidental em áreas de floresta tropical - térreas, com paredes de pau a pique (com ou sem fechamento da estrutura com barro ou folhagens), com cobertura de folhas de palmeira ou palha, piso em terra apiloada, com janelas externas ausentes ou de pequenas dimensões teriam servido de referência para as construções populares afro-americanas.

O historiador Rafael Marquese destacou que, em solo brasileiro, os escravizados teriam recriado técnicas de construção empregadas na zona congo-angolana, não só nos elementos formais construtivos (como no emprego de paus de forquilha para sustentação da cobertura em duas águas, formato retangular da planta, adoção de cômodos pequenos com ausência de janelas) mas, também, no uso das cabanas como local de abrigo e sono, enquanto todas as demais atividades se desenvolveriam no entorno da construção. ${ }^{19}$

Outro estudo recente que assinala parentescos entre África e Brasil na arquitetura é de autoria do geógrafo Rafael Sanzio dos Anjos. Em seu livro encontramos uma série de fotografias, produzidas desde o início do século XX até recentemente, de povoados na bacia do rio Congo na África equatoriana (fig.08), assim como de remanescentes de quilombos brasileiros (fig.09), comparando os materiais e técnicas construtivas empregadas, volumetria das construções e prática de atividades manuais e descanso nas áreas externas. ${ }^{20}$

O agrupamento de pequenas casas (com cerca de 3 metros de profundidade por 1,5 metros de largura) sob um grande telhado comum de palha ou folha de palmeira era comum entre Iorubás, um dos povos africanos que teve grande fluxo populacional para a colônia luso-

\footnotetext{
${ }^{19}$ Essa autonomia de agenciamento dos cativos na construção de suas habitações teria sido restringida quando a legalidade da escravidão começou a ter seu futuro ameaçado por conflitos internos e externos no Brasil, no início do século XIX. A partir da década de 1840, as maiores propriedades cafeicultoras do Vale do Paraíba passaram a normatizar a arquitetura das senzalas em quadras fechadas, organizadas em torno dos terreiros de café, observáveis a partir da vivenda senhorial e encerradas por portão único, ampliando o controle sobre o cativo.Ver: MARQUESE, 2005, loc.cit.

${ }^{20}$ ANJOS, Rafael Sanzio A. dos. Quilombos: Geografia africana - cartografia étnica, Territórios Tradicionais. Brasília: Mapas Editora \& Consultoria, 2009.
} 
americana. Marianno da Cunha e Pierre Verger registraram exemplares dessa tipologia construtiva na década de $1930 .^{21}$

Pensando as habitações aqui expostas como possíveis referências para análise dos quilombos setecentistas no Campo Grande, nos questionamos se essas construções, apesar de executadas em épocas e espaços distintos, teriam adotado tipologias, técnicas e materiais construtivos análogos.

\footnotetext{
${ }^{21}$ CUNHA, Marianno Carneiro da; VERGER, Pierre (fotos). Da Senzala ao Sobrado: arquitetura brasileira na Nigéria e República Popular do Benin. São Paulo: Nobel/Edusp, 1985. p.56-91.
} 


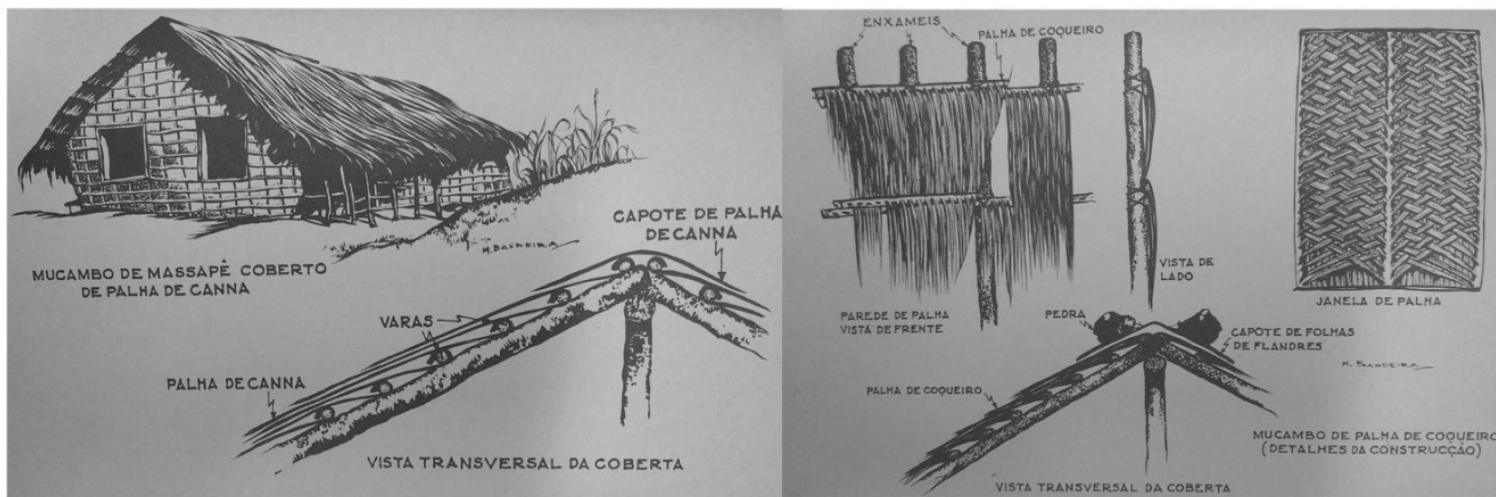

(Figura 01) perspectiva de mucambo e detalhes construtivos de cobertura, paredes e janelas Ilustrações de Manuel Bandeira. Fonte: Gilberto Freyre [1937]

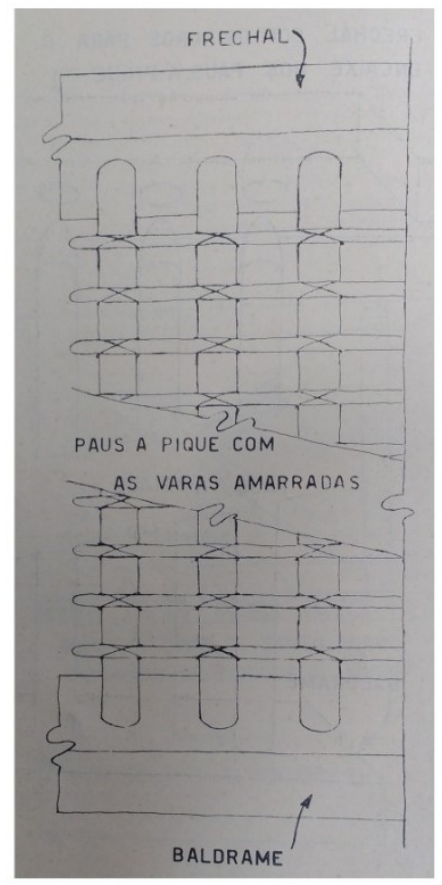

(Figura 02)

Estrutura de paus a pique com varas amarradas Fonte:Sylvio Vasconcelos

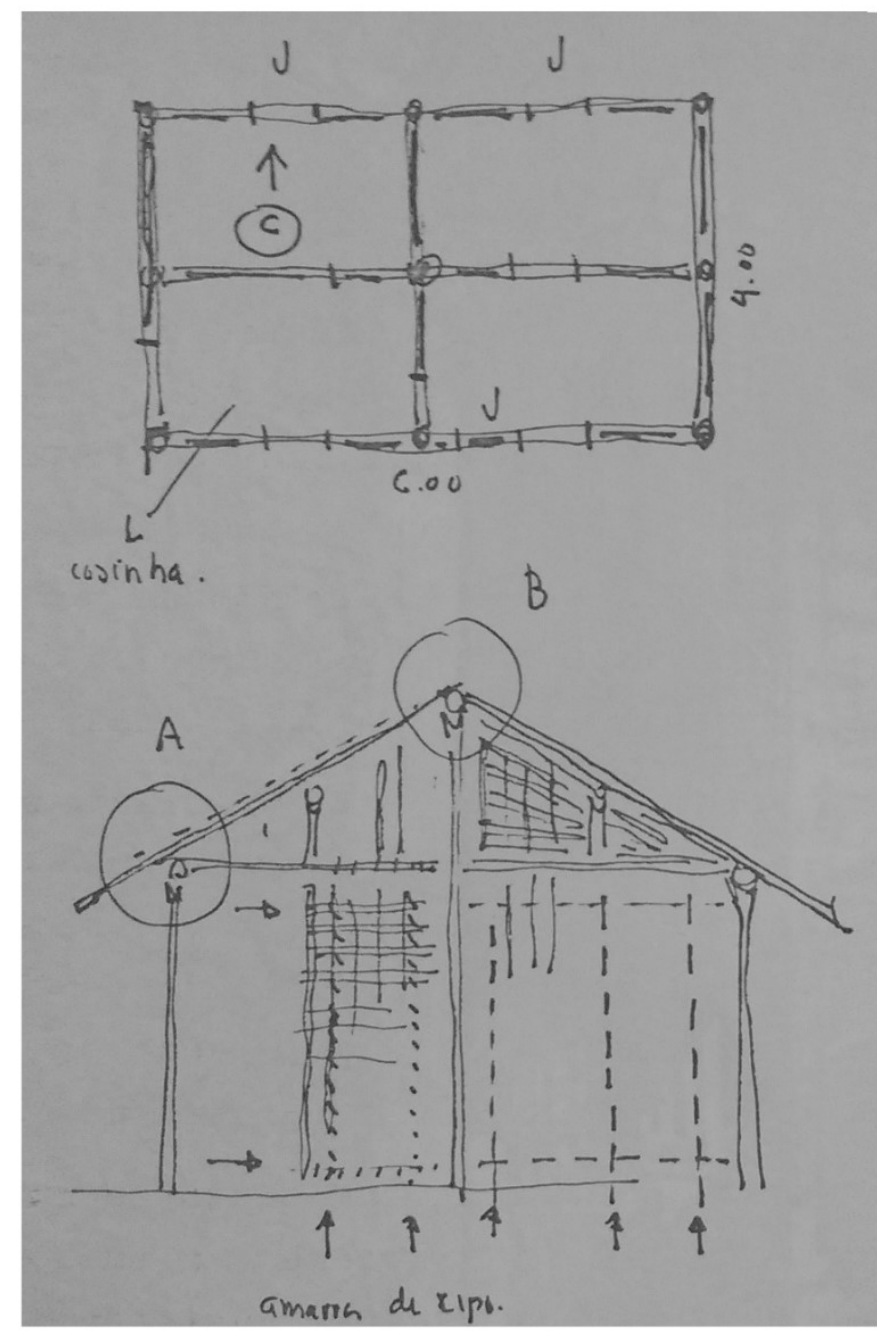

(Figura 03) Planta e vistas de residência em pau a pique Fonte: Antônio Luiz de Andrade 


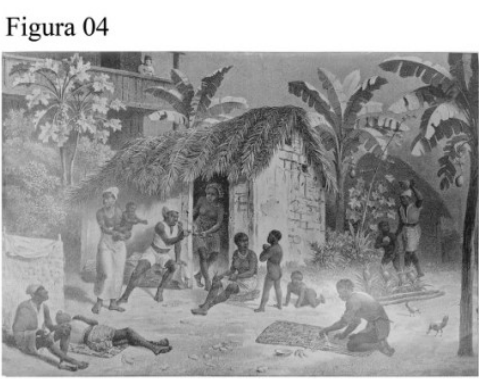

"Habitação de negros", litografia de I.L.Deroi a partir de desenho de J. M. Rugendas
Fonte: Robert Slenes

Figura 05

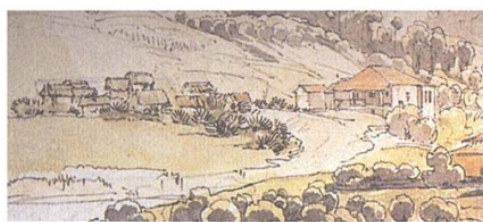

Fazenda do capitão Estevão, na passagem do Rio Piraí pouco antes de se entrar na Provincia de São Paul
desenho a lápis aquarelado de Thomas Ender, 181 Acervo do Gabinete de Gravuras da Academia de Belas Antes de Viena
Fonte: Rafael Marquese
Figura 06

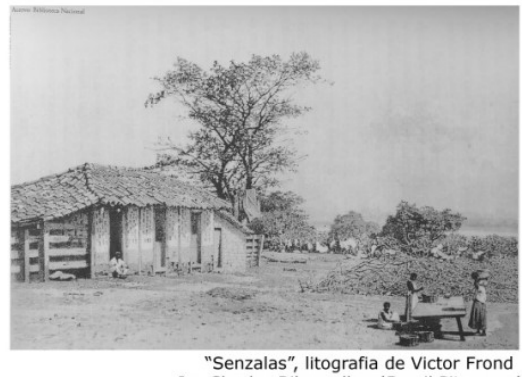

In: "Senzalas", Ittografia de Victor Frond Fonte: Robert Slenes
Figura 08

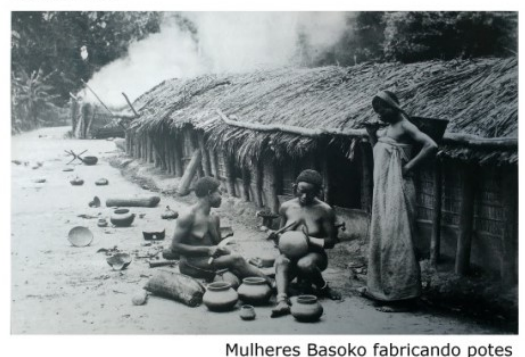

Mulheres Basoko fabricando potes fotografia anônima da coleção Mirac Tervuren Fonte: Rafael Sanzio A. dos Anjos
Figura 07

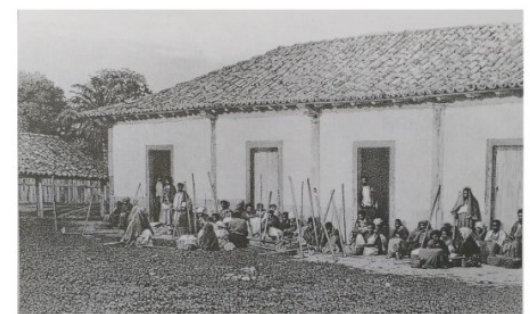

"Antes da partida para a roça", litografia de Victor Frond. In: Charles Ribeyrolles, 'Brasil Pitoresco'
Fonte: Robert Slenes
Figura 09

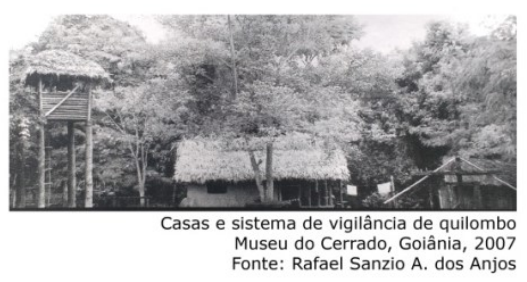




\subsection{3 - Arquitetura dos quilombos}

O emprego de estruturas de troncos de madeira "a pique", com esteios fincados diretamente no solo (sem fundação em pedra ou em outro material mais resistente à umidade), com paredes feitas em madeira e barro, aplicado com as mãos, foi atestado no levantamento arqueológico do quilombo do Ambrozio (como vimos no item 3.2). A abundância de madeira nas matas da região deve ter sido um fator decisivo na adoção desse material para as construções. É provável que os demais quilombos daquela zona também utilizassem tais elementos construtivos.

No entanto, poderíamos atribuir o uso do pau a pique e da taipa de mão nos quilombos às sobrevivências construtivas africanas, ou seriam apenas fruto da abundância desses materiais no ambiente e da escassez de recursos mais sofisticados? O uso da taipa de mão nas paredes exteriores das construções era recorrente tanto em certas regiões da África subsaariana, quanto em habitações populares nessas partes da América. Todavia, tais técnicas e materiais construtivos aplicados no Novo Mundo teriam necessariamente uma ascendência africana?

$\mathrm{Na}$ África Central equatoriana, em áreas úmidas com abundância de florestas, tiveram uso difundido as construções com pé-direto baixo, com poucas aberturas para exterior, feitas com estruturas de madeira. Todavia, essa era só uma entre as muitas tipologias, sistemas construtivos e materiais que eram empregados na arquitetura africana na época do tráfico negreiro, que derivavam de acordo com as ecologias locais, circunstancias históricas e cultura dos povos que as executavam. ${ }^{22}$

\footnotetext{
${ }^{22} \mathrm{Na}$ África ocidental (região sudoeste entre o oceano Atlântico e deserto do Saara), onde domina um clima mais seco e a vegetação de savana, com baixa umidade e frequência das chuvas, preponderavam construções em terra crua (adobe e taipa de pilão). Também eram utilizados tijolos de barro cozido. Entre os exemplos de edifícios tradicionais dessa zona estão a mesquita e centro de ensino de Sankore, construída no início do séc. XIV em Tombuctu e, os complexos habitacionais do povo Iorubá (compounds) de paredes e piso em barro, cobertura de material vegetal, organizados ao redor de pátios internos com implúvios ao centro.

$\mathrm{O}$ uso da pedra como material construtivo foi menos recorrente, mas foram encontrados exemplos em diferentes regiões como entre os Ovimbundu no século XVII (no sul da atual Angola), em casas do império Songaí entre os séculos XV e XVI ou, nas ruínas do Grande Zimbabwe entre os século X e XVI.

Dentro de uma única aglomeração urbana poderiam ser encontrados diferentes tipos de materiais construtivos, como na capital do Império de Gana, com auge no século X, cujas descrições falam em duas aglomerações separadas (uma para muçulmanos e outra cidade real animista com bosque
} 
Antes da difusão dos materiais construtivos industrializados, a disponibilidade de recursos naturais locais e influência climática eram alguns dos fatores dominantes na escolha das matérias-primas usadas para as edificações. Além das imposições do clima e recursos naturais disponíveis, o uso de diferentes materiais e técnicas, assim como as dimensões e adornos das construções, variam também de acordo com o poder econômico de seus usuários, da função do edifício, do tempo de uso da edificação, do poder político, econômico e religioso da cidade. Na África ou na América, a complexidade dos sistemas construtivos e a monumentalidade das edificações costumam se tornar mais pujantes de acordo com o crescimento do poder do grupo ou instituição que representam.

$\mathrm{Na}$ zona entre a serra da Canastra e Paracatu, décadas depois da conquista empreendida pelo Estado português, as habitações de diferentes grupos sociais eram caracterizadas pela rusticidade das construções. Segundo as descrições do naturalista francês Auguste de Saint-Hilaire (que viajou pela região em 1819 e em 1822), quase todas as edificações da região tinham paredes feitas de troncos de árvores e barro, sem reboco, com telhados feitos com troncos de palmeiras ou folhas vegetais, piso em terra batida, com cômodos escuros devido às poucas janelas, ou nenhuma, com quase ausência de móveis. $\mathrm{O}$ viajante se admira que, naquelas partes, tais "palhoças" eram moradia também de homens "brancos". De acordo com Saint-Hilaire, no ocidente do São Francisco, as "miseráveis habitações, todas feitas de barro", "pequenas e escuras" serviam de moradia também para os donos das fazendas, cujas casas mal se diferenciavam dos alojamentos de seus escravizados. ${ }^{23}$

sagrado) ligadas por avenida com casas de pedra e madeira e várias cubatas de teto arredondado; ou na cidade de Gao, do Império Songaí, onde foram contadas "7626 casas, mais cubatas de palha".

Ver: KI-ZERBO, Joseph. História da África Negra I. Sintra: Publicações Europa-América, 1972. p.133-141/ p.189/ p.233-237;

DENYER, Susan. African Traditional Architecture: an historical and geographical perspective. Londres: Heinemann, 1978;

CUNHA; VERGER, op. cit., p.56-9; Thierry Joffroy, 2005, p.74-79; WEIMER, 2005, loc. cit;;

WILLETT, Frank. Arte Africana. São Paulo: Edições SESC; Imprensa Oficial do Estado de São Paulo, 2017. p.128-149;

FREIRE, Karen. Materiais construtivos na África Subsaariana e sua influência sobre a arquitetura brasileira. In: $1^{\circ}$ Seminário em História e Fundamentos da Arquitetura e do Urbanismo/ Mestrado PPG AU USP, Caderno de Resumos/ org. Ana Castro. São Paulo: FAU/USP, 2018. p.45.

${ }^{23}$ SAINT-HILAIRE, Auguste de. Viagem às nascentes do rio S. Francisco. Trad. Regina R. Junqueira. Belo Horizonte, Ed. Itatiaia; São Paulo: EDUSP, 1975 [França, 1847]. p. 79-158. 
Considerando a difusão dessas cabanas de paus e barro entre diferentes estratos sociais na região, não compreendemos que o emprego desses materiais nas edificações dos quilombos estudados derivasse de uma simples predileção dos indivíduos de ascendência africana que ali estivessem. Além das imposições do clima e recursos naturais disponíveis, o uso de diferentes materiais e técnicas, assim como as dimensões e adornos das construções variam, também, de acordo com a pujança política e econômica da povoação, função do edifício e tempo de uso da edificação.

Nunca podemos perder de vista o caráter clandestino dos assentamentos quilombolas e a ferocidade com que eram combatidos pelos agentes lusitanos. Por isso, mesmo que a influência de hábitos e conhecimentos precursores tivessem algum papel na escolha da técnica, nos parece que a facilidade de acesso aos materiais e a simplicidade de execução das construções (que deviam ser erguidas rapidamente e que podiam ter de ser abandonadas a qualquer momento devido à aproximação de inimigos), deviam prevalecer na escolha dos materiais e acabamentos dedicados a eles.

A escassez de fontes documentais dificulta o desenvolvimento de maiores afirmações a respeito das configurações físicas dos quilombos. No entanto, podemos fazer algumas conjecturas a partir dos desenhos da expedição destruidora de 1769.

Estendendo as tipologias das construções abordadas anteriormente (item 3.3.2) como possíveis referências para os quilombos, observamos as implantações do Ambrozio, Sambabaÿa e Santos Fortes, quilombos onde as casas foram apresentadas em planta nos relatórios de 1769.

Para as ruínas do quilombo do Ambrozio (doc. G03) foram indicadas 33 construções. A maioria delas foi dividida, no desenho, em 2 partes e uma em 4 partes, possivelmente representando seus compartimentos, como vimos para a "Senzala" de Frond (fig.05). Assim, conseguimos contar ao menos 67 compartimentos para o Ambrozio, onde boa parte devia servir de moradia.

No mapa do Sambabaÿa (doc. G04) além da casa de ferreiro e da casa de audiência, há 11 construções para moradia, sendo que 7 delas estão dividas em 2 partes, 1 foi dividida em 8 partes e 3 não possuem divisão. Como dito acima, é possível que cada uma dessa partes representasse um cômodo para abrigo de várias pessoas. Sendo assim, teríamos 25 habitações no Sambabaÿa, totalizando 27 casas (de moradia, ferreiro e audiência). 
Já para o quilombo dos Santos Fortes (doc. G06) foram apresentadas 9 construções, cada uma com 2 compartimentos ${ }^{24}$, ou seja, 18 habitações.

Visto que as habitações nessa região geralmente eram pequenas (fossem para negros ou brancos), cada um cômodo deveria abrigar toda uma família ou grupo quilombola. Sendo assim, todos os quilombos registrados nos desenhos podiam abrigar dezenas de pessoas, ou centenas no caso do Ambrozio.

Esse total de 67 casas no Ambrozio, 27 no Sambabaÿa e 18 no Santos Fortes, é um número pequeno se comparado ao do "Mapa de todo o campo Grande [...]" (doc. M03), cujos quilombos tinham entre 70 e 220 casas cada um (segundo esse registro). Talvez os ajuntamentos quilombolas apresentados por tal mapa, referente a expedições precursoras, fossem realmente mais populosos. Talvez haja outras formas de estimar o número de casas nos registros da campanha de 1769. Respostas mais assertivas para o número de casas desses quilombos, assim como a densidade populacional desses ajuntamentos, demandam trabalhos de pesquisas em diferentes campos, não podendo esgotar as questões nesta dissertação.

Como apontado por Marquese, Gomes, Anjos e outros pesquisadores, é possível que as organizações sociais e hábitos culturais dos negros em diáspora nessas partes da América, se manifestassem também no uso das construções como abrigos e prática de atividades nas áreas externas no entorno das áreas construídas, ou também nos arranjos espaciais dos povoados. Observando os registros dos quilombos, parece razoável seguir por esse raciocínio, como veremos a seguir.

\footnotetext{
${ }^{24} \mathrm{O}$ desenho das divisões internas das casas do Santos Fortes, que atualmente se perderam da folha, podem ser vistas na reprodução do documento nos Anais da Biblioteca Nacional: ANBNRJ, 1988, p.109.
} 


\section{4 - OS QUILOMBOS DO CAMPO GRANDE NOS RETRATOS DE SEUS INIMIGOS}

Os sete quilombos encontrados pela expedição de 1769, liderada por Ignacio Correya Pamplona, tiveram alguns aspectos detalhados nos relatos da campanha, em suas narrativas textuais $^{25}$ e nos seis desenhos de implantação (ver doc. G01 ao G06), tendo as localizações de alguns deles pontuadas no mapa do trajeto da expedição (doc. M02).

Analisando as narrativas, percebemos que os cronistas estiveram pessoalmente no Ambrozio, Sambabaÿa, Santos Fortes (também chamado de Corisco) e Catigal (esse último sem desenho de implantação). Outros povoados foram acessados somente por uma das duas bandeiras da expedição de 1769 (que ora se destacavam do grupo de Pamplona, ora se reencontravam com o mesmo), caso dos dois quilombos da bacia do rio da Perdição e do Sam Gonçalo, sendo retratados nos documentos a partir dos esboços e informações trazidas pelos comandantes das bandeiras ou através de explicações dos próprios quilombolas capturados. Denunciados pelas fumaças avistadas ao longe pelas tropas, mas não encontrados pela expedição, outros quilombos tiveram sua região aproximada indicada nos manuscritos.

A partir dessas narrativas e ilustrações, podemos vislumbrar certas características dessas diferentes povoações, como o meio geográfico onde foram implantados, os tipos de produção para subsistência, o uso das construções, os sistemas de defesa e de organização social e as relações entre os núcleos quilombolas.

\subsection{1- Roças, Pilões e Manufaturas}

Todos os quilombos encontrados pela expedição de 1769 eram próximos de cursos d'água, que corriam em suas imediações ou atravessavam o interior dos povoados, sendo que o Catigal contava também com fontes de água salgada (mineral importante na alimentação animal) que nasciam na paragem chamada de Salitre. A oferta de água possibilitaria o abastecimento doméstico e facilitaria o cultivo de alimentos.

O quilombo Grande, também conhecido pelo nome de um famoso líder quilombola, Ambrózio, foi um dos maiores e mais afamados da região. Possivelmente sendo fundado na década de 1720, tal quilombo foi destroçado uma vez em 1746, ressurgiu na região pouco depois e foi novamente destruído em 1759, sendo que em ambos os eventos as expedições

\footnotetext{
${ }^{25}$ ANBNRJ, 1988, p.53-103.
} 
arrasaram muitas casas, paióis e roças ${ }^{26}$. Quando registrado pela campanha de Pamplona em 1769 restavam apenas ruínas do quilombo do Ambrozio ${ }^{[74]}$, dessa maneira tais expedicionários não puderam verificar os usos das edificações dessa antiga povoação ou os tipos e local de cultivo de alimentos. Por isso, tais informações inexistem nesses documentos.

Os demais quilombos apresentados eram ativos até aquele momento. Todos eles contavam com roças, sendo apontadas plantações de milho, mandioca, algodão e hortas. Os cultivos eram beneficiados pelos próprios quilombolas. A produção de farinhas aparece nas narrativas e na ilustração da "Caza de piloens" para o Sam Gonçalo.

No Sambabaÿa foi indicado um "Cortume de Couros", o que revela que nesse quilombo havia dedicação à atividade de tratar as peles de animais (que podiam ser usados na fabricação de calçados, recipientes para transporte ou mesmo para vestimentas e materiais para proteção contra flechas inimigas, como também era usado por índios e sertanistas ${ }^{27}$ ). Não há registro se as peles vinham de animais criados pelos quilombolas ou eram fruto da caça.

A manufatura de panos de algodão ou outros produtos com tal fibra foram sublinhadas nos quilombos do "chamado do Rịo da Perdiçaõ" [sic], "de hum dos braços da perdiçaõ" [sic], de Sam Gonçalo e dos Santos Fortes, através da identificação de "Caza de Thear" nos desenhos e relatos de confiscos pelas tropas dos panos de algodão feitos pelos calhambolas. A fabricação própria de ferramentas para cultivo ou armas em ferro foi indicada pela presença de uma "Caza e forge de ferreiro" no Sambabaÿa e no Sam Gonçalo pelo conjunto de "Cazas de ferreiro".

Pelos documentos da campanha bélica de 1769, percebemos que os quilombos encontrados pela mesma, não eram de ajuntamentos provisórios com uns poucos indivíduos, mas eram todos bem estruturados, com "ranchos", "modo de ali se conservarem" e com casas o bastante para comportar dezenas ou centenas de pessoas.

\subsection{2 - Organização social, conexão entre quilombos, reedificação de povoados}

As organizações sociopolíticas e cotidianos dos quilombos eram ignorados pelas tropas inimigas. A diversidade de arranjos sociopolíticos dessas povoações podem ser

\footnotetext{
${ }^{26}$ BARBOSA, 1972, p.31-53.

${ }^{27}$ HOLANDA, Sérgio Buarque de. Caminhos e Fronteiras. Rio de Janeiro: Ed. José Olympio, 1957. p.38-46 / p.136-142.
} 
entrevistas a partir das construções identificadas nas imagens, dos depoimentos extraídos dos quilombolas aprisionados e outros dados apresentados nas narrativas das expedições destruidoras.

As casas de ferreiro registrada no Sambabaÿa e Sam Gonçalo indicam não só a capacidade de autossuficiência na produção de ferramentas, mas (como figuras de liderança em culturas africanas ${ }^{28}$ ) os ferreiros podiam também estar relacionados à ordenação política desses povoados. O "chamado do Rịo da perdiçaô" contava com uma "Caza do Conselho", enquanto no Sambabaÿa havia uma "Caza de audiençia com aSentos" [sic] localizada próxima ao curso d'água e mata ${ }^{29}$, afastada das outras construções. No quilombo “de hum dos braços da perdiçaõ" foi identificada uma "Caza do Rey". Não há informações sobre a organização sociopolítica do antigo Ambrozio, Catigal ou Santos Fortes nos relatórios da campanha de 1769.

A existência de reis quilombolas aparece também em uma carta de 1759. Tal relato fala da destruição de 3 ou 4 quilombos localizados entre as capitanias de Minas Gerais e Goiás, todos subordinados a um quilombo maior, "onde residia a negra Corte, e o chamado Rey a que os mais obedecião", onde foram presos 50 homens e 50 mulheres $^{30}$. Nesse registro, nos chama a atenção a presença da figura chamada por rei, a constituição de um

${ }^{28}$ Em algumas culturas da África subsaariana o ícone do ferreiro era revestido de autoridade sociopolítica ou, até mesmo, religiosa. O conhecimento de técnicas de fundição de ferro para fabricação de ferramentas foi fundamental para o domínio dos povos bantos sobre a África central equatoriana, onde as florestas tropicais concorriam com a fixação de populações e cultivo de alimentos. Na África ocidental, a extração de ouro e uso do mineral em pó para comércio de longa distância com outros povos era uma prática secular. O tráfico humano da África para as colônias portuguesas na América fez com que as culturas africanas influenciassem as regiões que receberam essas pessoas. Ver: KI-ZERBO, op.cit., p.29-32, 122-126, 139-141, 172-416;

RUSSEL-WOOD, A. J. R. Escravos e libertos no Brasil colonial. Tradução por Maria Beatriz Medina. Rio de Janeiro: Civilização Brasileira, 2005. [Oxford, Inglaterra, 1982]. p.101;

GOMES, Flávio dos Santos. A hidra e os pântanos: mocambos, quilombos e comunidades de fugitivos no Brasil (séculos XVII-XIX). São Paulo: Ed. UNESP: Ed. Polis, 2005. p.358-395;

M'BOKOLO, Elikia. África Negra: história e civilizações v.1. Salvador: EDUFBA; São Paulo: Casa das Áfricas, 2009. p.11-14/ p.49-53/ p.168-180.

${ }^{29}$ Em religiões animistas africanas havia preservação dos bosques sagrados. Tais bosques figuraram no império de Gana por volta do século $\mathrm{X}$, sendo preservados até o século XV, quando ascenderam os Estados Hauças. No reino de Mbanza Congo (que teve seu auge entre os séculos XV e XVI) a floresta sagrada servia de necrópole real. Ver: KI-ZERBO, op. cit., p.133-141, p.194, p.233-236.

${ }^{30}$ AN cod.80 v.09 fl.105-1055v (ver transcrição no item 2.4). 
séquito em torno dessa liderança e a reunião dessa corte real negra em um dos povoados, cuja influencia sociopolítica se estenderia para outros ajuntamentos da região.

Não sabemos exatamente que tipos de arranjos políticos quilombolas eram esses nos quais foram identificados reis e cortes nos documentos luso-americanos. É possível que alguns quilombos de fato tivessem lideranças entendidas como reis, visto que essas eram figuras usuais naquele momento na África e Europa ${ }^{31}$, sendo que as instituições monárquicas da última se estendiam à suas colônias na América.

Em ambos os quilombos do rio da Perdição há o desenho de uma cruz entre dois totens em “i” que, provavelmente, representa a presença de cemitérios no interior desses povoados. Implantados no centro do quilombo, junto às casas do rei e do conselho, esses cemitérios podiam ter relação com práticas de reverência aos ancestrais e com a identidade de linhagem ${ }^{32}$ dos quilombolas, com a manutenção dos restos mortais dos antepassados perto das habitações e locais de culto religioso.

Uma longa passagem do relatório dos mapas, que apresento adiante, nos permite vislumbrar importantes detalhes sobre o funcionamento dos quilombos analisados como a devoção a um santo católico, a reedificação de quilombos, a conexão entre povoados e a especialização de ao menos um deles como local para plantação de alimentos:

"No dia 29 [...] sobimos a Serra de São Rafael [...] por onde Conhecemos que ia a picada velha de Goiases [...]. Do chapadão desta Serra vimos o lugar do Quilombo de São Gonçalo ${ }^{79}$ [,] o qual o comandante de uma das Bandeiras[,] o Tenente José da Serra Caldeira[,] de repente topou e nele amarrou um Negro que ali estava e os mais fogiram para onde novamente estavam outros camaradas estabelecendo outro novo Quilombo para breve mente se modarem todos, e ali só estavam alguns que se ocupavam em fazer farinhas para os mais[,] as quais o mesmo Comandante confiscou junto com vários trastes e panos de Algudões feito[s] ricamente pelos mesmos Negros, do qual por me dar tão fiel cópia fiz o presente Mapa para ademiração do munto que eles trabalham para Si.

Indaguei a rezão por que se nomeava Quilombo de São Gonçalo, e achei que os primeiros povoadores que tinham estado em outro Quilombo nas Cabeceiras do Rio das onze

\footnotetext{
${ }^{31}$ MARTINS, Tarcísio José. Quilombo do Campo Grande: História de Minas que se devolve ao povo. Contagem: Santa Clara, 2008. p.178-187.

${ }^{32}$ Entre os Iorubás, os ancestrais mortos eram enterrados nos pátios junto às moradias das famílias extensas e tais cemitérios privados se ligavam à identidade de linhagem das mesmas. Nos terreiros de candomblé brasileiros, espaços de celebrações religiosas e reunião comunitária de matriz africana, também há reverência aos antepassados. Ver: CUNHA, op. cit., p.45; SILVA, Vagner Gonçalves . Candomblé e Umbanda: caminhos da devoção brasileira. São Paulo: Selo Negro, 2005. p.63-65.
} 
mil virgens donde sairam por padecerem ai uma grande Epidimia que os obrigou a devota mente fazerem ofericimento ao dito Santo a ereção de um novo Quilombo com o título de São Gonçalo [...].

No dia 30 fomos seguindo o rumo da dita picada velha que em partes nos aparecia e tendo andado Légua e meia ${ }^{89}$ topamos um corgo... em que o dito Senhor deu o nome de Santa Iria [...], o qual passamos e seguindo o mesmo Rumo chegamos de Frote do Quilombo de Santos Fortes em ${ }^{90}$ [,] distante pouco menos de uma Légua[,] onde Largamos a dita picada e fomos ao dito Quilombo para ver se achávamos alguns Negros dos que tinham fogidos do Quilombo da Samambaia[,] e neste Lugar os destroçou e saquiou grande quantidade de panos de Algudões e feitos nos dito Quilombo e outros mais Ro[u]bos que eles tinham feito[,] ali nos demoramos de se plantar a Roça que eles tinham queimado por Cuja rezão tive tempo de tirar o Mapa do dito Quilombo,[...] e como prometi das maior Individuação do Quilombo da Samambaia[,] digo que estes Negros estavam em um Quilombo em ums dos Braços da perdição[,] ao pé de outro Quilombo na mesma perdição [...], e daqui se retiraram o ano passado a fazerem roça na Samambaia por lhe ficar mais perto para conduzirem o seu Mantimento e dai melhor estabalecer; Este Quilombo, cuja notícia so[u]bemos por um Negro que o dito José Cardoso amarrou[,] vindo-se retirando da Samambaia para este que antigamente se chamava do Corisco outro que aqui houve[,] de que ainda se vê vestijos [,] por Cair um raio a[r]Redado dele meia Légua, Lugar por onde nos passamos e se vê ainda os regos que abriu a Terra.", 33

Quanto ao Sam Gonçalo, além da constatação de algum tipo de devoção ao santo católico pelos quilombolas, para o qual foi oferecida a ereção desse quilombo, é interessante a transposição desse povoado para outra região narrada nesse excerto. Enquanto os "primeiros povoadores" estavam estabelecidos perto das nascentes do rio das Honze mil virgens, junto a Serra das Mangabas, devido a uma epidemia uma nova geração de moradores (que podiam ser seus descendentes ou novos integrantes agregados posteriormente) refez o quilombo em uma área de campinas no vale entre as serras de São Rafael e Santa Fê. Na narrativa transparece que a mudança de local de habitação não extinguiu a relação de continuidade com o povoamento original. Tomando medidas a partir do petipe e $^{34}$ indicado no mapa, podemos estimar a distância, em linha reta, entre ambos os quilombos de aproximadamente 12 léguas (percurso que não poderia ser transposto em menos de dois dias de marcha por uma tropa em terreno livre sem maiores dificuldades advindas do relevo ou hidrografia).

A conexão entre os quilombos de "hum dos braços da perdiçaõ" e Sambabaÿa, apontada no trecho acima, chama a atenção. Segundo a descrição, os habitantes do quilombo

\footnotetext{
${ }^{33}$ ANBNRJ, 1988, p.102.

${ }^{34}$ Como já visto, "petipé” é uma escala gráfica usada na época. A medida adotada podia ser gravada em régua de latão ou madeira para servir de instrumento para levantamento em campo e, depois, para transposição dessas medidas para os mapas. Ver: BUENO, op. cit., p.38-40.
} 
de um afluente do rio da Perdição ${ }^{[q]}$ foram para o Sambabaÿa ${ }^{[76]}$ (distantes aproximadamente 7 léguas) pelo local ser mais apropriado para fazer roça e ali melhor se estabelecerem. No entanto, o dito quilombo de "hum dos braços da perdiçaõ" não foi esvaziado para fundação do Sambabaÿa, mas continuava ativo até a invasão da bandeira de 1769. Sendo assim, ambos povoados existiam simultaneamente.

A proximidade do Sambabaÿa ${ }^{[76]}$ e do antigo Ambrozio ${ }^{[74]}$ (a menos de 2 léguas de distância no mapa M02), ambos na subida da serra das Mangabas ${ }^{[\mathrm{tt}]}$, também é motivo de nota. O Ambrozio foi erguido e reerguido nessas partes, permanecendo na região por ao menos quatro décadas, sendo extinto em 1759 pela expedição comandada por Bartolomeu Bueno do Prado ${ }^{35}$. No entanto, dez anos depois, outro quilombo foi encontrado por Pamplona na mesma região, dessa vez sendo nomeado pelos expedicionários como Sambabaÿa. Assim, a área onde estava o Sambabaÿa e o Ambrozio se mostrava particularmente interessante para a implantação dessas povoações clandestinas. O registro de criação do Sambabaÿa por colonos do rio da Perdição, que foram até esse local (distante mais de um dia de marcha) para lá "fazerem roça" e "melhor estabalecer", evidencia que essas terras eram especialmente adequadas ao cultivo. Esse quilombo talvez pudesse servir de pouso para fazerem plantio e colheita, para então “conduzirem o seu Mantimento" para outros povoados que compusessem a mesma comunidade ${ }^{36}$.

A ligação do Sambabaÿa ${ }^{[76]}$ com o Santos Fortes ${ }^{[90]}$ (afastados cerca de 13 léguas um do outro no mapa M02) foi ratificada pela prisão de um quilombola que ia do primeiro para o segundo, sendo que a expedição conseguiu chegar ao Santos Fortes a partir da informação extraída desse prisioneiro. Esse trânsito de habitantes entre os quilombos evidencia que havia relações entre as povoações. O quilombo dos Santos Fortes, cujo acesso era em meio a matas fechadas, estava implantado próximo ao antigo Corisco, cujo local teria sido atingido por um raio que abriu vão na terra. Não foi informado se os habitantes do extinto Corisco e do Santos Fortes eram os mesmos ou, se a nova povoação foi fundada por diferentes colonos, preferindo o local por vantagens geográficas.

\footnotetext{
${ }^{35} \mathrm{O}$ quilombo do Ambrozio teve a reputação de ser o maior existente na região das minas no século XVIII, para sua destruição foi organizada tropa de cerca de 400 homens em 1746. Ver: GUIMARÃES, 1999, p. 197-198 / p.238; BARBOSA, 1972, p.31-53

${ }^{36}$ Outra possibilidade é que os quilombolas conduzissem tal mantimento para o comércio clandestino com luso-americanos que eventualmente se encontrassem por ali, opção menos provável já que a região contava com presença restrita de súditos lusitanos naquele momento.
} 
A reedificação de um novo quilombo no mesmo local de um anterior inativo aparece também no relato para o Catigal. Naquela paragem

"[...] esteve já muntos anos e há poucos se tornou a retificar um quilombo chamado o Catiguá, de mais de cento e cinquenta jiraus, sendo certo que foi quilombo de munta força e de munto poder, o que claramente se evidenceia, porque havendo nestas paragens muntos matos, os mais próximos ao lugar do mesmo quilombo todos estão destruídos e safados das muntas e repetidas plantas que os Negros ali fizeram [...]". 37

Segundo a descrição, esse povoado que no passado, contava com mais de uma centena e meia de construções (que, tomando por modelo os ajuntamentos vizinhos representados nos relatórios, deviam ser usadas umas para habitações e outras para beneficiamento das produções, organização política local ou outros), tinha como evidência de sua antiga "força" e "poder" a dimensão da clareira aberta em meio à mata fechada (feito que exigia grande dedicação de trabalho assim como disponibilidade de ferramentas para derrubada de árvores e demais vegetação). Esse espaço era desmatado para fazer plantio de roças e construções do quilombo.

Próximo à serra de São Rafael, junto ao ribeirão do Salitre, o povoado do Catigal ${ }^{[91]}$ estava localizado a pouco mais de uma légua da mata do Salitre ${ }^{[92]}$ (ver M02), onde as fontes de água salgada atraíam animais, havendo, assim, fartura de caça. Tendo a primeira povoação sido extinta em momento anterior, talvez devido ao ataque de tropas inimigas, o quilombo foi novamente edificado sobre o mesmo espaço. No novo Catigal foram feitas roças pelos calhambolas, cujos restos da colheita de milho foram apropriados pela campanha de 1769. A preferência desse sítio para ereção do quilombo devia estar relacionada à disponibilidade de recursos naturais favoráveis à manutenção de povoados.

\subsection{3 - Fortalezas e mirantes}

Como recurso para suas defesas, esses quilombos estavam implantados nos arredores de morros, que eram usados para avistar os inimigos ao longe. Apenas em duas povoações não foram registradas "espias" nos relatórios. Ainda assim, também nelas os quilombolas souberam com antecedência da chegada dos inimigos e fugiram.

${ }^{37}$ ANBNRJ, 1988, p.75. 
As ruínas do quilombo do Ambrozio possuíam estrutura de fortaleza. Como vimos na análise do desenho de implantação, encerrando o centro habitável por todos os lados havia uma trincheira com guaritas que, por sua vez, era envolta em três faces por um fosso com aproximadamente 3,40 metros de largura, crivado de estrepes ${ }^{38}$, enquanto o trecho oeste era protegido por um brejo com buracos e estrepes.

A partir da proporção gráfica em "Petipé" inserida na legenda do documento, podemos medir que a trincheira teria cerca de $100 \times 100$ metros, encerrando área de $10.000 \mathrm{~m}^{2}$. O núcleo fortificado do Ambrozio limitado pelo fosso ocuparia aproximadamente de 125x125 metros, com área total de $15.625 \mathrm{~m}^{2}$. Como visto, tal estimativa de área através do petipé é coerente com as informações do levantamento arqueológico do Ambrozio ${ }^{39}$.

A construção de fortificações também é verificada no Sam Gonçalo. De acordo com o desenhista da campanha de Pamplona, o espaço habitável desse quilombo era protegido por uma larga trincheira de aproximadamente 2,30 metros de altura, com dois pares de buracos para fuga, acessível por uma entrada com dois fojos (buracos) e por uma saída com estrepes apontados para o exterior da povoação. Esses dispositivos, aparentemente, inviabilizavam o acesso ao quilombo a cavalo ou por tropas de pedestres em velocidade. Essa povoação possuía matos ao redor da trincheira, estando situada no mapa da expedição entre duas serras, em região de campinas, podendo ser avistada ao longe pelos luso-americanos que eventualmente viajassem pela picada velha de Goiás.

Uma vez que o Ambrozio e Sam Gonçalo não ficavam em meio à mata fechada, mas rodeado por restingas de matos e campinas, as estruturas fortificadas e a utilização de morros próximo da povoação como mirantes para espia eram fundamentais para a preservação do povoado e de seus moradores. Nos outros quatro quilombos encontrados pela campanha de 1769 não foram representadas construções de estruturas fortificadas.

A fortificação de cidades era comum em diferentes partes da África subsaariana, sendo registradas entre os Iorubás e nas impressionantes ruínas em pedra do Grande Zimbabwe (entre os séculos X e XVI), nos Estados Hauças e no reino de Mbanza Congo (nos séculos XV e XVI). Segundo o historiador Ki-Zerbo, nesse antigo reino na região do rio Congo, uma

\footnotetext{
${ }^{38}$ Estrepes são pontaletes agudos fincados ao solo para dificultar o acesso dos inimigos aos espaços por eles protegidos. Nesse caso, provavelmente eram feitos de madeira.

${ }^{39}$ Ver item 3.2
} 
cerca de estacas e cipós com aproximadamente $1 \mathrm{~km}$ de perímetro protegia a cidade e uma segunda paliçada com labirinto guardava a casa do rei e rainha. ${ }^{40}$

É interessante a similaridade das fortificações construídas com paliçadas de madeira de Mbanza Congo com aquelas presentes nos registros de certos quilombos no Campo Grande. Além dos desenhos da campanha de 1769 para o Ambrozio e Sam Gonçalo, há outros registros de quilombos com fortificações e armadilhas em cartas oficiais. Em 1746 o governador de Minas Gerais falava de quilombo no Campo Grande com mais de "mil negros e grande número de crias" que uniram poder elegendo um rei e construindo um "palanque assaz forte ${ }^{\text {"41 }}$. Como podemos ver em carta de Gomes Freire para o vice-rei, pelo menos dois quilombos nos arredores da Comarca do Rio das mortes foram destruídos em 1746 por uma tropa composta de 400 homens. Um dos quilombos destruídos era "armado de duas estacadas, e um fôço, semeado de estrépes", onde estavam "106 negros" que se defenderam com "furor"

Não foram descritas reações armadas dos quilombolas contra as tropas nos documentos da expedição de 1769. Para os dois quilombos na bacia do rio da Perdição, falase de mortos (cujo número não foi informado) e de um prisioneiro, tendo os demais fugido. No Sambabaÿa, no Santos Fortes e no Catigal houve fuga; no Sam Gonçalo a maioria fugiu, sendo alguns pegos de surpresa fazendo farinha. Os expedicionários acreditavam que os calhambolas se refugiavam em outros quilombos próximos. É notável que, apesar da provável superioridade de armamentos da campanha de Pamplona, o perigo e temor das tropas sobre o enfrentamento contra "Negros" foram destacados nas narrativas.

O desconhecimento da região pelos luso-americanos e a dificuldade de acesso a alguns quilombos, em meio às matas fechadas, favoreciam a permanência desses povoados "clandestinos" na região. Mesmo nas áreas onde as fumaças indicavam a existência de povoados $^{[85,87]}$, nem sempre as tropas destruidoras tiveram sucesso em encontrá-los. Com o encerramento da campanha de 1769 , ainda se mantiveram alguns quilombos nas imediações do novo caminho aberto pela expedição.

\footnotetext{
${ }^{40}$ KI-ZERBO, op. cit., p.191-196, p.204/ p.233-236; CUNHA, op. cit.1985, p.91.

${ }^{41}$ Carta de Gomes Freire para el Rei de 1746 do acervo do Arquivo Público Mineiro (APM cod.50 fl.43-44 / cod. 45 fl.64v-65) analisada em: GUIMARÃES, 1999, p. 197-198/ p.238.

${ }^{42}$ AN cod. 84 v.11 fl.164v-165v (ver transcrição no capitulo 02)
} 


\subsection{4 - Rede quilombola no Campo Grande e meios de manutenção}

Os quilombos documentados pela campanha de 1769 apresentavam configurações bem distintas, uns em matas fechadas outros em campinas, alguns fortificados, outros contando com recursos do ambiente para sua defesa, cada um com seu conjunto de construções que apontam diferentes organizações sociopolíticas e tipos de produção. Todos tinham em comum a presença de cursos d'água, eram ao menos parcialmente envoltos por matas e tinham áreas para cultivo de roças.

O registro de "roças", "pilões" e manufaturas nesses povoados quilombolas, assim como a capacidade de abrigo de dezenas de pessoas mesmo entre os menores deles, indicam alguma estabilidade desses ajuntamentos no local, assim como sua capacidade de suprir a própria demanda de subsistência. Ainda que ataques de quilombolas contra os lusoamericanos (em fazendas e estradas) pudessem ocorrer, não parece que tais atividades estivessem relacionadas à subsistência desses quilombos, visto que eles tinham meios próprios de manutenção.

A partir dos relatos de 1769 e de outros registros da época, verificamos que alguns dos povoados estavam relacionados a outros da região, havendo indícios de que quilombos em diferentes locais cumprissem funções especializadas, como fornecimento de alimentos, organização sociopolítica (em torno de reis, conselhos, assembleias ou outros tipos de lideranças) ou religiosa (onde talvez se incluíssem os cemitérios). Assim, podemos afirmar que diferentes quilombos compunham uma comunidade maior, cujos integrantes estavam dispersos em diferentes aglomerações constituintes de uma mesma rede quilombola.

Como os quilombos encontrados tiveram suas localizações indicadas nos mapas produzidos pelas expedições que os destruíram (mapas M01 ao M03), a partir de tais cartografias históricas podemos ter uma boa ideia das áreas onde estavam implantados os povoados quilombolas. Com as informações extraídas desses documentos, vemos no mapa atualizado construído nesta pesquisa (mapa K01) que, até a década de 1780, a região que abrange o rio Grande e cabeceiras do São Francisco, Paranaíba abrigou ao menos três dezenas de quilombos e somente alguns poucos povoados luso-americanos. 


\section{5 - POVOAÇÕES NO CAMPO GRANDE NO SÉCULO XVIII}

A vasta região conhecida no século XVIII por Campo Grande fica em zona de planalto intertropical, na faixa de transição entre os domínios morfoclimáticos do cerrado (de fraca fertilidade do solo e menor densidade hidrográfica e cobertura florestal) e dos "mares de morro" (com rede hidrográfica perene e originalmente recoberto por mata atlântica), apresentando características intermediárias de ambos ${ }^{43}$. Nessas áreas nascem os rios Paranaíba e São Francisco (nomes atuais), englobando também parte da bacia do rio Grande.

O "Mapa de todo o campo Grande [...]" (M03) retrata essa zona como um todo, cujas áreas abrangiam desde o rio Grande ao rio das Mortes, ao sudeste, até os rios Pernayba e Corumbá, ao noroeste.

A campanha liderada por Pamplona em 1769 fez o reconhecimento de parte do Campo Grande, desde o vale aos pés das serras da Canastra e Piuhÿ, adentrando a cadeia de serras no entorno do rio Quebra anzol até próximo ao ribeirão do Salitre, percorrendo trajeto exposto no mapa da expedição (M02). O "Mappa da Conquista do Mestre de Campos [...] Pamplona" (M01) tem foco principal na mesma região que o anterior.

Todas as fontes primárias estudadas tem em comum o destaque dado aos quilombos que foram combatidos por expedições luso-americanas. Através dos marcos geográficos indicados nos documentos, pudemos cruzar as informações expostas pelos mesmo em um mapa contemporâneo único (K01).

Comparando os dois mapas relacionados ao Pamplona, notamos que alguns dos ajuntamentos apresentados no mapa da expedição de 1769 (M02) são os mesmos indicados no "Mappa da Conquista [...]" (M01), caso dos quilombos do Ambrozio, Sambabaÿa, Santos Fortes, Sam Gonçalo e Catigal. Os dois quilombos junto ao rio da Perdição (G01, G02) registrados em 1769 não aparecem no mapa dos anos 1780. Talvez durante a execução do novo mapa a real posição deles tenha sido corrigida, sendo na verdade localizados antes da subida da serra da Marçella junto a outros rios afluentes do São Francisco, podendo se tratar dos quilombos N³0, N³1 ou No32 (dois entre eles). Talvez a localização dos quilombos do rio da Perdição tenha sido ignorada em ambos os mapas, e os quilombos №30, No31, No32 e

\footnotetext{
${ }^{43}$ AB' SÁBER, Aziz. Os domínios de natureza no Brasil: potencialidades paisagísticas. 2.ed. São Paulo: Ateliê editorial, 2003. p.11-31; ROSS, Jurandyr L. Sanches. Os fundamentos da geografia da natureza. In: ROSS (org.). Geografia do Brasil. 5ed. São Paulo: Edusp, 2005. p.32-65.
} 
No42 (todos eles) tenham sido destruídos por Pamplona em outros momentos. O “Mappa da Conquista [...]" expõem também a localização de quilombos combatidos por diferentes agentes portugueses.

As regiões abordadas pelos documentos de Pamplona foram representadas também no “Mapa de todo o campo Grande [...]” (M03), apresentando alguns quilombos em comum.

Como visto no item 2.3, alguns dos quilombos que aparecem no mapa M03, provavelmente são os mesmos que surgem no auto de posse dos territórios explorados pela expedição de 1759 de Bartolomeu Bueno do Prado ${ }^{44}$. Dessa maneira, o quilombo do Mammoi seria também conhecido como Bamboy, que ficava nas margens do rio com mesmo nome. A proximidade com tal rio indica que o Mammoi ou Bamboy, seja o quilombo Nº33 destruído pelos "Boinos" do mapa M01.

O Sam Gonçalo e Ambrozio aparecem em todos os mapas estudados.

Quanto ao Sam Gonçalo (ou S. Goncalo ou N³7), os três mapas o inserem entre os rios Grande e Pernayba, tendo sua localização melhor definida nos documentos de Pamplona, que o coloca no vale ao sul do rio Quebra-anzol, na margem oposta de onde estava o Santos Fortes. Como o "Mapa de todo o campo Grande [...]" foi produzido anteriormente (entre os anos de 1763-1768) e a campanha de 1769 encontrou tal ajuntamento habitado, dois quilombos identificados como Sam Gonçalo na mesma região foram invadidos em diferentes momentos. Sendo assim, um novo quilombo foi reerguido no mesmo local ou em região próxima do anterior, talvez pelos mesmos habitantes que fugiram e depois retornaram, ou talvez por outras pessoas, que tenham encontrado ali uma área apropriada para $o$ estabelecimento de suas moradias, roças, pilões, tear e forje de ferreiro.

No "Mapa de todo o campo Grande [...]" (M03) uma primeira povoação do Ambrozio $^{[137]}$ aparece ao oriente das nascentes da bacia do São Francisco, entre os rios Grande, Lambari e Jacaré. A localização desse primeiro Ambrozio ${ }^{[137]}$ é coerente com a descrição de sua destruição em 1743, nas imediações do rio Formiga, pelo capitão Vicente da Costa Chaves ${ }^{45}$.

O novo quilombo do Ambrozio ${ }^{[136]}$, implantado em área afastada da primeira povoação, pode ter se originado a partir da fuga dos moradores do anterior, ou ambos os

\footnotetext{
${ }^{44}$ BARBOSA, 1972, p.41-53.

${ }^{45}$ BARBOSA, 1972, p.34
} 
ajuntamentos, apesar de conhecidos pelo mesmo nome, poderiam ter população, conformação espacial, organização econômica e sociopolítica diversas.

Esse quilombo Ambrozio ${ }^{[43}$ ou 74 ou 136] para além da serra da Marçella foi localizado entre os rios das Velhas, Pernayba e cabeceiras do São Francisco em todas as cartografias analisadas, tendo seu posicionamento mais bem definido nos mapas de Pamplona (M01 e M02), que os localizam próximo ao rio de Santa Thareza, afluente do Quebra-Anzol. É provável que os três mapas estejam se referindo às ruínas do mesmo povoado.

O Ambrozio (ou quilombo Grande) implantado na face ocidental do São Francisco foi destruído um vez em 1746 pelo capitão Antônio João de Oliveira, por uma expedição de 400 homens armados, e novamente em 1759, por Bartolomeu Bueno do Prado ${ }^{46}$. Os mapas estudados não registram o momento de sua destruição nem nos falam qual expedição foi responsável por tal feito. Desse modo, o quilombo do Ambrozio figura nesses documentos não para noticiar seu combate, mas como ponto de referência para exploração daquelas paragens.

Ainda no "Mapa de todo o campo Grande [...]" (M03), são indicados mais 16 quilombos na margem sul do rio Grande, e outros três quilombos ao norte do rio Pernayba, para os lados do rio São Marcos. Não analisamos todos os povoados expostos em tal mapa nessa pesquisa, visto que não estão no foco central da dissertação. Contudo, mesmo sem poder definir as características de cada um dos quilombos expostos nos documentos, podemos verificar a profusão de quilombos nessa área, todos eles com grande número de moradores.

Olhando os documentos em conjunto no mapa que construímos para a pesquisa (K01) vemos que a zona do Campo Grande não abrigava apenas uns poucos ajuntamentos isolados, mas um importante número de povoados quilombolas. Desconsiderando aqueles quilombos que provavelmente estão repetidos nos documentos, nos três mapas que se referem a eventos registrados entre as décadas de 1740 e 1780, foram indicados cerca de 40 quilombos, contra aproximadamente uma dúzia de povoações luso-americanas no Campo Grande.

A partir das informações extraídas dos documentos dos inimigos, vemos que os quilombos predominavam nos "sertões" do Campo Grande, sendo que esses não eram simples ajuntamentos improvisados, mas contavam com complexas estruturas para suas manutenções.

\footnotetext{
${ }^{46}$ BARBOSA, 1972, p.31-53.
} 
A ênfase dada pelos documentos dos agentes lusitanos à presença de reis, de conselhos ou assembleias quilombolas pode ser lida como uma forma de acentuar o caráter de insubordinação desses povoados quilombolas, que não integravam a estrutura administrativa e eclesiástica portuguesa na América, mas pertenciam a outras organizações sociopolíticas. Essas dezenas de quilombos do Campo Grande possivelmente não estavam todos conectados por uma única malha sociopolítica, mas, como vimos, muitos deles compunham uma única comunidade distribuída em diferentes núcleos de povoamento com funções específicas.

Aqueles povoados quilombolas intercambiavam produtos para subsistência, recebiam refugiados de ataques inimigos e alguns podiam servir de centros sociopolíticos ou religiosos de outros. Essa integração dos povoados, organizados em uma ou mais redes quilombolas, constituía um tipo de colonização naquela região, diferente do que estava sendo construída pelos súditos da coroa Bragança.

A abundância de quilombos nessa zona fazia com que o conjunto deles formasse uma só entidade inimiga aos olhos dos agentes portugueses, sendo motivo de grande temor e perigo para aqueles que se arriscassem a adentrar aqueles sertões.

O domínio do Campo Grande pelos calhambolas chamava a atenção das autoridades do Estado português, que dedicava esforços para combatê-los, visando substituir aqueles colonos rivais por outros subordinados à coroa lusitana.Várias guerras foram empreendidas pelas autoridades luso-americanas em busca de extinguir tais inimigos. Mesmo com a derrubada de dados quilombos, outros povoados se formavam na região.

A dedicação dos agentes portugueses à produção de mapas e relatos detalhados sobre os quilombos do Campo Grande indicam, a um só tempo, o interesse deles nessa zona e a dificuldade de se apropriarem daquele território devido à ação dos quilombolas.

A influência dos quilombos sobre o Campo Grande, no século XVIII, foi tão expressiva que a referência aos povoados mais famosos, como o Ambrozio, aparecia nos documentos de identificação das fazendas implantadas sobre suas terras e a expressão “quilombo" aparece na toponímia de rios, serras e povoados da região até hoje. ${ }^{47}$

As fontes analisadas mostram que os meios de apropriação da região pelo Estado português envolveu a destruição dos quilombos e o uso do território quilombola para construção de estradas e concessão de terras para súditos lusitanos naquelas paragens.

\footnotetext{
${ }^{47}$ BARBOSA, 1972, p.34 /p. 85-86.
} 


\section{6 - POVOAÇÕES CONCORRENTES NAS BORDAS DO OURO}

\subsection{1 - Povoamento do Campo Grande e cercanias}

As regiões do Alto São Francisco e Alto Paranaíba, onde estavam implantados os quilombos aqui analisados, eram vizinhas de áreas de exploração aurífera no século XVIII que se encontravam a leste na serra do Espinhaço (onde ficava o distrito diamantino, a cidade de Mariana, vila Rica, vila do Sabará, entre outras); ao sul em alguns trechos da bacia do rio Grande; ao norte junto ao rio Paracatu, entre outras ${ }^{48}$ (ver mapa K01). Nessas áreas mineradoras e suas imediações, os cativos eram predominantemente africanos ou descendentes dos mesmos e as fugas desses indivíduos para os quilombos, ainda que não fossem maciças, eram recorrentes. ${ }^{49}$

As manchas de povoamentos subordinados ao Estado português nessa região eram restritas. Os relatórios da expedição de Pamplona de 1769 definem os limites da colonização luso-americanaao longo do caminho que saía das vilas de São José e São João rumo a Paracatu. De acordo com esses memoriais, a área entre o rio Grande e o rio Jacaré encontravase já povoada naquele momento. Porém, passadas somente 5 léguas do arraial de Nossa Senhora da Oliveira indo em direção ao Piuhÿ e Bambohÿ, o povoamento era escasso e com parco alcance do poder eclesiástico. A serra da Marçella era marco de fronteira do "Sertão". A partir dali, não morava mais ninguém além dos "negros calhambolas".

A parte da região do Campo Grande explorada por Pamplona em 1769 situava-se em meio a uma cadeia serras conhecidas hoje por Canastra, Bocaína, Negra, Zagaia e outros nomes (tendo a denominação "Marçella" caído em desuso), que concentram nascentes da bacia do Paranaíba e São Francisco. Em meados do século XVIII essa zona era "ilegalmente" povoada à revelia do Estado português. A presença abundante de quilombos nessas partes foi reafirmada a todo tempo nos documentos estudados.

\footnotetext{
${ }^{48}$ RESENDE, Maria Efigênia Lage de. Itinerários e interditos na territorialização das Geraes. In: RESENDE; VILLALTA (org.). As Minas Setecentistas, vol.1. Belo Horizonte: Autêntica; Companhia do Tempo, 2007. p.25-53; FONSECA, Cláudia Damasceno. Arraiais e vilas d'el rei: espaço e poder nas Minas setecentistas. Tradução de Maria Juliana G. Teixeira. Belo Horizonte: Ed. UFMG, 2011. p. 25-81.

${ }^{49}$ ANBNRJ, 1988, p.64;

RUSSEL-WOOD, A. J. R. Escravos e libertos no Brasil colonial. Tradução por Maria Beatriz Medina. Rio de Janeiro: Civilização Brasileira, 2005. [Oxford, Inglaterra, 1982]. p.51-81;

SOUZA, Laura de Mello e. Desclassificados do ouro: a pobreza mineira no século XVIII. Rio de Janeiro: Ed. Graal. $4^{\circ}$ edição, 2004. p.100.
} 
Temendo o confronto com os calhambolas, os escreventes da campanha de 1769 se referiram ao sertão do Campo Grande como "infestado por negros", ao mesmo tempo em que divulgaram a expedição de Pamplona como promotora do "povoamento" naqueles espaços. Com esse discurso era justificado o extermínio dessas populações não integrantes da ordem colonial portuguesa. Para viabilizar a nova povoação luso-americana, as tropas abriram estrada e montaram pousos para os viajantes.

\subsection{2 - Expedições militares, estradas e ranchos para tropas}

Uma tentativa anterior de ocupação desse sertão por agentes da coroa lusitana foi evidenciada nos relatórios de Pamplona pela existência da "Picada velha de Goiases, feita por Urbano Couto", que passava próximo do quilombo dos Santos Fortes. Porém, desse caminho só restavam seus vestígios, não tendo vingado seu uso naquelas partes ${ }^{50}$.

A estrada nova aberta no sertão do Campo Grande pelas tropas de 1769 conectava os povoados do Ambrozio, da Sambabaÿa, do Santos Fortes e do Catigal. Por essa razão, a estrada construída por Pamplona ${ }^{[\mathrm{d}, \mathrm{o}]}$ traçada no "Mappa da Conquista do Mestre de Campos [...] Pamplona" (M01) coincide com alguns dos quilombos por ele destruídos.

Para facilitar a entrada de outras campanhas através do novo acesso, a expedição de 1769 cultivou víveres ao longo do caminho ${ }^{51}$. Como visto, essas roças não foram feitas em qualquer parte, mas sobre as terras desses quilombos, uma vez que essas estavam preparadas para o cultivo e onde, provavelmente, os locais mais adequados já tinham sido selecionados. Algumas das variedades plantadas pelas tropas coincidiam com as cultivadas pelos calhambolas como milho, mandioca e algodão. Assim, os quilombos foram transformados em ranchos para o descanso e abastecimento dos entrantes luso-americanos.

É provável que a apropriação dos quilombos por agentes portugueses para constituição de sua própria estrutura colonial fosse uma prática corrente na região, cujos indícios verificamos em documentos de outras expedições.

\footnotetext{
${ }^{50}$ ANBNRJ, 1988, p.96-103

${ }^{51} \mathrm{O}$ cultivo de alimentos por tropas pioneiras para facilitar a exploração de novas áreas de conquista era uma prática usual entre bandeirantes paulistas. Ver: HOLANDA, op. cit., p.160-179; FONSECA, op. cit., p.61.
} 
Segundo o "Mapa de todo o campo Grande [...]" (M03), a expedição do capitão Antônio Francisco França arranchou no "Quilombo queymado chamado a Boa Vista, já a tempos demolido", abrindo estrada entre os quilombos do Boa Vista e do Cascalho (tendo destruído pessoalmente o último) para procurar ouro nos arredores.

A coincidência entre quilombos e estradas constatada no "Mappa da Conquista do Mestre [...] Pamplona" (M01b) talvez se deva a mesma lógica. É o caso da Picada de Goŷas ${ }^{[\mathrm{c}]}$ com os quilombos N³3, No39 e Ambrozio 43, da estrada de São Romão ${ }^{[\mathrm{g}]}$ e para Piracatú ${ }^{[\mathrm{j}]}$ com o quilombo $\mathrm{N}^{\mathrm{0}} 34$, além da estrada feita por Pamplona (que também aparece nesse mapa) com os quilombos $\mathrm{N}^{\circ} 32, \mathrm{~N}^{\circ} 36, \mathrm{~N}^{\mathrm{o}} 38$ e Ambrozio 43. É possível que tal justaposição de quilombos com estradas se devesse a diferentes expedições adotarem a mesma estratégia de destruir os quilombos encontrados e usar suas terras para montar a novas estruturas lusoamericanas para apropriação das paragens.

Tal superposição da estrutura colonial lusitana era também uma forma de posse simbólica dos territórios quilombolas. A demolição seguida pela substituição dos quilombos pelo aparato de seus conquistadores extinguia aqueles povoados quilombolas duas vezes: como entidades físicas e como memória de suas existências.

\subsection{3 - Padroado régio e ocupação dos territórios americanos pelo Império lusitano}

Como promotora da "civilização" naquelas partes ${ }^{52}$, a campanha de Pamplona providenciou a construção de templos católicos, concedeu sesmarias e tomou posse de tais "sertões" para a capitania de Minas Gerais em nome do governador conde de Valadares, formalizada por atos públicos.

O Estado português era indissociável da Igreja católica por meio do padroado régio, acordo no qual, em troca da promoção da fé católica no Novo Mundo, o recolhimento de impostos eclesiásticos era destinado à coroa Bragança ${ }^{53}$. Por esse motivo, nas terras que a expedição de Pamplona buscava conquistar, foram erguidos templos, colocadas imagens religiosas, fincadas cruzes e demarcados patrimônios eclesiásticos junto aos arraiais. Esses

\footnotetext{
${ }^{52}$ SOUZA, Laura de Mello e. Norma e conflito: aspectos da História de Minas no século XVIII. Belo Horizonte: Ed. UFMG, 1999. p.111-137.

${ }^{53}$ FONSECA, op.cit., p.82-123.
} 
símbolos institucionais assinalavam a conquista daqueles locais pelo poder monárquico católico, ao mesmo tempo em que intentavam suprimir as organizações sociopolíticas e religiosas preexistentes, quilombolas ou indígenas.

Como abordado no item 1.5, o século XVIII foi marcado por disputas entre os reinados ibéricos pelo direito de exploração dos territórios na América do Sul. Com os novos tratados, firmados entre Igreja católica e monarquias europeias, o reconhecimento da soberania se dava pela ocupação efetiva do território. Essas conquistas eram documentadas por meio de mapas e memórias, que se transformavam em matéria de negociação entre os Estados $^{54}$.

Inferimos, assim, que as campanhas militares estudadas estavam alinhadas com o projeto português de ampliação e afirmação de seus domínios, ao buscar estender a presença da igreja católica e da administração civil sobre esses locais "remotos", viabilizando sua ocupação por súditos da coroa lusitana e, ao fim das expedições, destinando ao governo da capitania relatórios com mapas e descrições cartográficas das terras conquistadas.

A partir dos relatórios da expedição bélica de Pamplona no Campo Grande em 1769, vemos que a estrutura colonial luso-americana fundada por essa campanha foi feita através do estabelecimento de ranchos para descanso dos tropeiros, fazendas, patrimônios da igreja e arraiais superpostos à rede quilombola ali estabelecida.

Tal sobreposição fazia com que o restabelecimento dos povoados quilombolas naqueles locais fosse dificultado, mas também resultava no ocultamento dos vestígios e memória daqueles quilombos.

\subsection{4 - Arraiais luso-americanos sobre territórios quilombolas}

Os arraiais luso-americanos instalados em meio aos territórios que estavam em processo de apropriação serviam de instrumentos de controle da população submetida àquela estrutura de poder. Depois de estabelecidos, funcionavam como postos avançados para novas frentes de conquista. Com esse propósito foram fundadas as povoações de Tamandoá (em

\footnotetext{
${ }^{54}$ KANTOR, Íris. Cartografia e diplomacia: usos geopolíticos da informação toponímica (17501850). Anais do Museu Paulista, São Paulo, v.17, n.2, p.39-.61, jul.-dez. 2009.
} 
1757), de Piuhy (em 1758) e de Bamboy (em 1768) ${ }^{55}$. Esse foi o objetivo declarado no discurso de Pamplona ao demarcar os arraiais de Nossa Senhora da Conceição e de Santa Maria de Cortona do Salitre (em 1759).

É importante observar que, segundo os relatórios de Pamplona, o arraial de Santa Maria de Cortona do Salitre ${ }^{[93]}$ foi demarcado nas imediações do quilombo do Catigal ${ }^{[91]}$. Já o arraial de Nossa Senhora da Conceição foi estabelecido juntamente com o patrimônio para sua capela e a fazenda que Pamplona destinou para si mesmo, em área limitada pelo rio das Honze mil virgens ${ }^{[81]}$, quilombo do Ambrozio ${ }^{[74]}$, córrego do Sacramento ${ }^{[77]}$, córrego do Bom Jesus $^{[75]}$ e serra de São Pedro de Alcantra ${ }^{[78]}$, polígono que abrange o quilombo da Sambabaÿa ${ }^{[76]}$ (ver áreas tracejadas em verde no M02). ${ }^{56}$

Destruído em 1759, o quilombo do Bamboy (ou Mammoi ${ }^{[135]}$, ou No33 nos mapas M01 e M03) ficava nas margens do rio de mesmo nome e, portanto, na mesma região do futura Matriz de Santa Anna de Bamboŷ. Sendo assim, áreas nos arredores do quilombo do Bamboy, ou talvez o próprio quilombo, teriam sido apropriadas pelos luso-americanos para a fixação de sua povoação com igreja e da estrada que ligava Tamanduá (Tamandoâ) com Paracatu (ou Piracatú) através dos sertões da serra da Marçella (ver M01 e K01).

Colhendo relatos entre a população local décadas depois, o viajante Saint-Hilaire afirmou que o arraial do Piuhy foi originado a partir de um acampamento montado próximo a esse rio para combater um agrupamento de "negros fugidos" que tinham se embrenhado na serra da Canastra ${ }^{57}$.

\subsection{5 - Acesso à terra}

As atividades econômicas tributárias do Estado colonial português eram fundadas sobre a escravidão, tanto como mão de obra, quanto como critério de distribuição de terras. As concessões de datas para extração de ouro e minerais preciosos, assim como a de

\footnotetext{
${ }^{55}$ FONSECA, op. cit., p.25-45/ p. 120.

${ }^{56}$ ANBNRJ, 1988, p.70, p.101.

57 SAINT-HILAIRE, Auguste de. Viagem às nascentes do rio S. Francisco. Trad. Regina R. Junqueira. Belo Horizonte, Ed. Itatiaia; São Paulo: EDUSP, 1975. [França, 1847]. p.96-97.
} 
sesmarias para cultivo e criação de gado, estavam condicionadas ao número de escravizados que o proponente possuía ${ }^{58}$, fato que foi reforçado no discurso de Pamplona.

Antes da lei de terras em 1850, nos tempos de colonização portuguesa as terras não eram propriedades privadas juridicamente mercantilizadas, mas tinham seus direitos de uso concedidos pelo Estado de maneira formal ou informal, como exposto por Fânia Fridman.

Os súditos lusitanos pobres (livres ou alforriados) podiam estabelecer suas moradias e cultivos através de "posses mansas e pacíficas" sobre terras da coroa que fossem reservadas para o uso coletivo, constituindo um tipo de acesso informal à terra.

Já para a obtenção de um título formal do direito de exploração das glebas concedido pela coroa Bragança, desde meados do século XVIII, era necessária a comprovação pelos requerentes da capacidade de produção sobre as mesmas, através da quantidade de escravizados que possuíssem e dos meios de manter seu domínio pela força de armas. As terras desbravadas que não tivessem ocupação e produtividade suficientes eram consideradas devolutas, devendo ser repassada a quem tivesse meios de fazê-lo. ${ }^{59}$

A apropriação de novas terras para exploração agropecuária através do trabalho de escravizado, com confirmação da posse através da concessão de sesmarias, foi um dos frutos das investidas de Pamplona no Campo Grande.

Como retribuição da coroa pela realização dessa e outras campanhas no Alto São Francisco e Alto Paranaíba, Ignacio Correya Pamplona (nascido em ilha nos Açores e casado com uma filha de escravizada vinda da Costa da Mina) se tornou um dos maiores proprietários de terra da região, recebendo em seu nome e de sua família a concessão de várias sesmarias. As sesmarias concedidas naquela zona mediam 3 léguas de largura por 3 de comprimento, totalizando 9 léguas em quadra ${ }^{60}$.

\footnotetext{
${ }^{58}$ GUIMARÃES, 1999, p.46; SOUZA, 2004, p. 47-48.

${ }^{59}$ FRIDMAN, Fania. Donos do Rio em nome do rei: uma história fundiária da cidade do Rio de Janeiro. Rio de Janeiro: Jorge Zahar Ed.: Garamond, 1999. p.55-82.

${ }^{60}$ BARBOSA, Waldemar de Almeida. A decadência das Minas e a fuga da mineração. Belo Horizonte: Imprensa da Universidade Federal de Minas Gerais, 1971. p.17-47, p.124-125.
} 
Considerando a medida usual na cartografia da América portuguesa de 1 légua equivalente a 6,522 quilômetros ${ }^{61}$, cada uma dessas sesmarias teriam aproximadamente 38.283 hectares ou $382,83 \mathrm{~km}^{2}$. Para se ter ideia da magnitude dessas extensões de terras, comparando com certas localidades dessa mesma região ${ }^{62}$, caberiam apenas 2 ou 3 sesmarias de 3x3 léguas dentro dos atuais municípios de Piumhi, São Gotardo, Araxá, Bambuí, São João del Rei e Itapecerica (antiga São Bento do Tamanduá), ou 7,5 sesmarias em Patrocínio (próximo do quilombo do Catigal).

A repartição de territórios quilombolas entre aqueles que se dedicaram à destruição de povoados quilombolas e à expansão os domínios do império lusitano sobre o Campo Grande parece ter sido uma prática comum.

A região entre Formiga e Piuhy teve algumas sesmarias concedidas, a partir do fim década de 1730, como retribuição aos abridores da estrada que ligava as regiões mineradoras das capitanias de Goiás e Minas Gerais, no entanto, esses sesmeiros não conseguiram se fixar na região, que era dominada por quilombolas. Como participante de expedições de combate a quilombos e busca de ouro em 1759 (ou 1760), o capitão Antônio Francisco França estabeleceu fazenda de gado nos arredores de Piuhy. ${ }^{63}$

Como retribuição à expedição de 1759 contra os quilombos do Campo Grande, que tomou posse da região entre o Piuhy e o Pernayba para a capitania de Minas Gerais, Bartolomeu Bueno do Prado recebeu a concessão de sesmaria de 1x3 léguas, em paragens que conheceu durante aquela empreitada, entre os recém fundados arraiais de Piuhy e Tamandoá. $\mathrm{Na}$ mesma região, Francisco Ferreira Fontes combateu quilombos em meados da década de 1750 , fixando fazenda entre os rios Lambari e São Francisco. ${ }^{64}$

Próximo ao quilombo do Catigal (e da atual cidade de Patrocínio), na década de 1770, o capitão Inácio de Oliveira Campos estabeleceu fazenda após combater quilombos na serra Negra (aprisionando 50 negros que foram devolvidos aos proprietários em Paracatu) ${ }^{65}$.

\footnotetext{
${ }^{61}$ SANTOS, Márcia Maria Duarte dos. Técnicas e elementos da cartografia da América portuguesa e do Brasil Império. In: COSTA, Antônio Gilberto. Roteiro prático de cartografia: da América portuguesa ao Brasil Império. Belo Horizonte: ed. UFMG, 2007. p.51-81.

${ }^{62}$ Áreas calculadas a partir dos dados disponíveis In: IBGE, 2010.

${ }^{63}$ BARBOSA, 1971, p.31-36; BARBOSA, 1972, p.47.

${ }^{64}$ BARBOSA, 1972, p. 47-65.

${ }^{65}$ BARBOSA, 1971, p.62-63.
} 
Vemos assim que, os súditos lusitanos proprietários de escravizados que "conquistavam" os "sertões" do Campo Grande "infestados de negros" (destruindo quilombos, construindo estradas e defendendo suas terras do ataque dos "calhambolas"), podiam estabelecer fazendas que atendessem as demandas do Estado luso-americano.

Os beneficiários das sesmarias não precisavam ser nascidos na metrópole ou na colônia luso-americana, desde que contribuíssem com a confirmação do império português. Pamplona era um aventureiro nascido na Ilha Terceira do arquipélago de Açores (uma pequena ilha no meio do Atlântico), casado com Eugênia Luisa da Silva (filha de pai desconhecido e de mãe trazida da Costa da Mina), cujos filhos legítimos (seus herdeiros e também sesmeiros) eram, portanto, netos de uma escravizada africana. Esses indivíduos se tornaram uma das famílias com mais amplos domínios de terras na região. Assim, o que prevalecia para a concessão formal de terras eram os serviços prestados à majestade portuguesa.

No entanto, a titulação formal do direito de uso de terras era restrita aos nascidos livres, sendo vedada aos escravizados e alforriados, mesmo que esses "negros" tivessem se dedicado à extinção de quilombos em nome da coroa Bragança. ${ }^{66}$

A construção de moradia em terras públicas por famílias luso-americanas pobres (que viviam da caça, coleta ou cultivo próprio de viveres), assim como cultivo de alimentos por escravizados em lotes no interior das fazendas de seus proprietários eram práticas comuns, constituindo formas de acesso informais às terras, consonantes àquela estrutura social ${ }^{67}$. Ao contrário, a fuga de escravizados para regiões afastadas com estabelecimento de povoados onde mantinham suas produções de subsistência e organização sociopolítica independente era inadmissível pela ordem colonial lusitana na América.

\footnotetext{
${ }^{66}$ GUIMARÃES, 1999, p.90-97 / p.279-280.

${ }^{67}$ SAINT-HILAIRE, 1974 [1847], p.22-24; FRIDMAN, op.cit., p.133; SLENES, op. cit., p.131-236.
} 


\section{4 - CONSIDERAÇÕES FINAIS}

O desejo de conhecer mais sobre o legado dos povos afrodescentes para a formação de nossa sociedade foi o que moveu esta investigação. Ambição vultosa em decorrência da magnitude do tema, cuja satisfação é restrita devido à escassez de registros documentais disponíveis.

Os acervos públicos que preservam documentos do Estado colonial português nas Américas, produzidos entre os séculos XVI e XIX, forneceram os meios necessários para explorar alguns aspectos dos povoamentos pregressos desses povos. Através desses arquivos, pudemos acessar três preciosas peças cartográficas que expõem uma mesma região, período e assunto: o combate dos quilombos por agentes lusitanos na zona do Campo Grande em meados do século XVIII.

Tivemos, então, o privilégio de poder dedicar estudos minuciosos aos mapas e aos poucos escritos relacionados a eles. Empreendendo uma vagarosa análise dessas relíquias iconográficas (observando a composição do desenho, peso e traçado das linhas, símbolos adotados para representação dos elementos, decifrando cada uma das palavras e números expostos nos textos apresentados nos mapas). Realizando leituras exaustivas dos relatos associados às expedições destruidoras dos quilombos. Buscando compreender o contexto e nexo dos dados que surgiam neles através de diferentes autores. Transpondo as informações das fontes para mapas recentes para possibilitar uma abordagem espacial daquele território. Tudo isso para procurar pistas que pudessem nos levar alguns passos adiante na construção de respostas possíveis para nossas inúmeras perguntas.

Sem ter esgotado os assuntos possíveis de serem explorados a partir dessas fontes primárias, os objetos e objetivos desta pesquisa foram adaptados ao breve tempo e arcabouço teórico disponíveis. Os documentos guiaram este estudo por interessantes caminhos. Neles constatamos eventos inicialmente inesperados pela pesquisa, que abriram novas perspectivas.

Foi no momento de contato entre adversários e a extinção dos quilombos que, contraditoriamente, foram gerados os documentos que hoje nos oferecem um dos poucos vestígios sobre os quais podemos vislumbrar a história dessas povoações quilombolas. A partir do exame dos manuscritos oficiais produzidos em meados do século XVIII, concentrando-nos sobretudo nos relatórios da expedição militar de 1769 liderada por Ignacio Correya Pamplona, compreendemos algumas características dos quilombos registrados, assim 
como os métodos adotados pelas tropas destruidoras para converter os territórios quilombolas em parte integrante da estrutura colonial do Estado lusitano.

Distantes alguns dias de marcha de núcleos mineradores, a região serrana onde nascem os rios São Francisco e Paranaíba e seus arredores no vale do rio Grande abrigou dezenas de quilombos desde a década de 1720 ou ainda antes. Todos os quilombos aqui analisados estavam instalados nas margens de cursos d'água, possuíam roças e alguns contavam com fortificações, pilões, teares, cortume, cemitérios, casas de ferreiros, de rei, de conselho e de audiência. As construções provavelmente eram executadas com recursos disponíveis no ambiente, como madeira e barro, usando técnicas de rápida execução. Cada um desses núcleos quilombolas devia contar com dezenas ou até centenas de habitantes, onde deviam predominar indivíduos africanos, misturados com ameríndios e descendentes de ambos.

As relações entre diferentes quilombos, através do fluxo de habitantes e de alimentos, foram confirmadas pelos relatórios da expedição destruidora de 1769, sendo provável que esses povoados estivessem também inter-relacionados em suas organizações sociopolíticas, com cultivo de alimentos em um quilombo e enterro dos mortos em outro, por exemplo. Dessa maneira, podemos pensar esses povoados não só como unidades autônomas, mas também como integrantes de uma rede quilombola mais ampla, onde núcleos com diferentes atribuições funcionavam em conjunto uns com outros.

Mesmo após diversas batalhas contra expedições militares do Estado lusitano, os quilombos permaneceram naquelas paragens ao longo do século XVIII, sucessivamente refazendo suas construções e roças nos mesmos locais ou nas imediações.

Os quilombos do Campo Grande no século XVIII tiveram tamanha influência na região que seus povoados, mesmo depois de destruídos, continuavam sendo referência para os agentes lusitanos. Caso do quilombo do Ambrozio, que décadas depois de arruinado, continuava servindo como ponto de orientação nos mapas produzidos para o Estado português. A derrubada dos quilombolas pelos súditos da coroa Bragança demandou expedições bélicas, implantação de novos povoados, fazendas, estradas, patrimônios religiosos e destacamentos militares.

Na visão dos agentes do Estado português, suas expedições a um só tempo eliminavam a "infestação de negros" e viabilizavam o "povoamento dos sertões" com seus súditos. Em outras palavras, enquanto uma ação era entendida como povoadora, a existência de habitantes 
bem estabelecidos ali (com produção própria de alimento, manufatura de ferro e tecidos, entre outros) era relacionada a uma praga que estava indesejavelmente disseminada na região. Esses povoados quilombolas eram declarados como prejudiciais à colonização luso-americana uma vez que ameaçavam a última, devido ao risco de assaltos nas estradas ou de perda de escravizados das fazendas e arraiais. Além disso, percebemos nos relatos que um dos principais problemas dos agentes portugueses contra os quilombos era que, como os últimos possuíam suas próprias organizações sociopolíticas, eles não eram subordinados ao sistema colonial luso-americano. Ou seja, estavam fora do alcance econômico, legal e tributário da monarquia portuguesa.

Analisando episódios onde grupos rivais (com diferentes arranjos sociopolíticos culturais) se confrontaram pelo domínio dessa região que hoje integra o triângulo mineiro Grande, podemos afirmar que as povoações quilombolas ali existentes foram usadas como base de implantação da estrutura física destinada à instalação de súditos da coroa Bragança.

A nova estrutura colonial subordinada ao governo da capitania de Minas Gerais naquele sertão, não se distinguia da quilombola preexistente nem pelo local de implantação dos ranchos para descanso das tropas, nem pelas espécies cultivadas nesses pousos, nem pelo trajetos das estradas (cujos traçados conectavam alguns dos quilombos encontrados), nem mesmo na escolha dos sítios para fundação de novos arraiais, patrimônios eclesiásticos e fazendas (que foram demarcados nas imediações dos quilombos ou sobre eles).

O que diferenciava fundamentalmente esses dois tipos adversos de ocupações territoriais eram as formas de acesso à terra. Os "negros" fugitivos obtinham suas liberdades e terras à revelia do Estado português, ou seja, ilegalmente e de maneira instável. Já a colonização luso-brasileira era amparada pela organização estatal à qual estava submetida, cujos aparatos bélicos e institucionais facilitavam seu estabelecimento no local de forma perene.

A estratégia de ocupação por sobreposição à rede quilombola adotada pela expedição de Pamplona parece ter sido adotada também por outras campanhas militares naquele momento de expansão colonial portuguesa. A superposição do povoamento luso-americano sobre as estruturas quilombolas no Campo Grande (trocando uma população de rebeldes por outra de indivíduos subordinados às leis, costumes, religião e tributação da coroa lusitana), tinha como sinalização da conquista ibérica a abertura de estradas, construção de marcos 
religiosos, execução de rituais de posses de terras acompanhados por músicos e comitiva montada, entre outros.

Ao mesmo tempo em que intentavam exterminar os habitantes rivais, a implantação desses símbolos ocultava a memória dos povoados quilombolas. Ainda assim, os quilombos teimavam em reaparecer na região mesmo após sucessivas destruições pelas tropas do Estado português, cuja superioridade bélica, até aquele momento, não era grande o bastante para que suas investidas contra os quilombolas fossem livres de temor e de dificuldades pelos agentes lusitanos.

Como saldo geral deste trabalho, ressalto o protagonismo dos povoados quilombolas para nossa História. A relevância dos quilombos na região do Alto São Francisco, Alto Paranaíba e vale do rio Grande, inclusive, para a formação da malha territorial portuguesa da qual somos herdeiros, reforça nossa premissa de que os saberes sobre o passado das populações afrodescendentes são de interesse não apenas para grupos circunscritos, mas constituem parte indissociável da construção daquilo que veio a ser o Brasil. 


\section{REFERÊNCIAS BIBLIOGRÁFICAS ${ }^{1}$}

\section{DOCUMENTOS MANUSCRITOS}

\section{Arquivo Nacional, Rio de Janeiro}

Carta de Gomes Freire para o vice-Rei, 1746. Arquivo Nacional do Rio de Janeiro, Secretaria de Estado do Brasil, códice 84, vol. 11, fl. 164v-165v

Carta do Conde de Bobadella para Tomé Joaquim da Costa Corte Real de 1759. Arquivo Nacional do Rio de Janeiro, Secretaria de Estado do Brasil, códice 80, vol.9, fl. 105-105v.

\section{Arquivo Histórico Ultramarino, Lisboa, Projeto Resgate}

Mappa da Conquista do Mestre de Campos Regente Chefe da Legião Ignacio Correya Pamplona. [ca.1784] Papel. 1 mapa, color., 32,4 cm x 39,9cm. Manuscrito. Português. Arquivo Histórico Ultramarino, Projeto Resgate, código: AHU_CARTm_011, D.1165.

\section{Biblioteca Nacional, Rio de Janeiro}

[Mapa do trajeto da expedição de 1769 de Ignacio Correya Pamplona]. [ca.1769]. Papel. 1 mapa, color., $90 \mathrm{~cm}$ x $43 \mathrm{~cm}$. Manuscrito. Português. Biblioteca Nacional, Rio de Janeiro, Coleção Ottoni, arquivo conde de Valadares, Coleção Ottoni, código: MS-575 (1), folha 245.

Mapa de todo o campo Grande tanto da parte da comquista, que parte com a Campanha do Rio verde e S. Paulo como de Piuhy cabeceyras do Rio de S. Francisco, e Goyazes. [176-]. Papel. 1 mapa, color., $89,5 \times 43 \mathrm{~cm}$. Manuscrito. Português. Instituto de Estudos Brasileiros IEB-USP, Coleção Yan de Almeida Prado, código: YAP-023-016.

Quilonbo chamado do Rio da perdiçã̃. [1769?]. Papel. 2 folhas. Manuscrito. Português. Biblioteca Nacional, Rio de Janeiro, Coleção Ottoni, arquivo conde de Valadares, código: MS-575(1), folha 258259.

Quilonbo de hum dos braços da perdiçaõ. [1769?]. Papel. 2 folhas. Manuscrito. Português. Biblioteca Nacional, Rio de Janeiro, Coleção Ottoni, arquivo conde de Valadares, código: MS-575(1), folha 250-251.

Quilonbo da Sambabaÿa. [1769?]. Papel. 1 folha. Manuscrito. Português. Biblioteca Nacional, Rio de Janeiro, Coleção Ottoni, arquivo conde de Valadares, código: MS-575(1), folha 243.

Quilonbo de Sam Gonçalo. [1769?]. Papel. 1 folha. Manuscrito. Português. Biblioteca Nacional, Rio de Janeiro, Coleção Ottoni, arquivo conde de Valadares, código: MS-575(1), folha 244.

Quilonbo do Ambrozio. [1769?]. Papel. 2 folhas. Manuscrito. Português. Biblioteca Nacional, Rio de Janeiro, Coleção Ottoni, arquivo conde de Valadares, código: MS-575(1), folhas 238-239.

[Quilonbo] dos Santos fortes. [1769?]. Papel. 1 folha. Manuscrito. Português. Biblioteca Nacional, Rio de Janeiro, Coleção Ottoni, arquivo conde de Valadares, código: MS-575(1), folha 253.

\footnotetext{
${ }^{1}$ De acordo com a Associação Brasileira de Normas Técnicas (ABNT NBR 6023).
} 


\section{DOCUMENTOS IMPRESSOS}

[Encontrando Quilombos]. Transcrição e edição paleográfica por Maria Filgueiras Gonçalves. Anais da Biblioteca Nacional, Rio de Janeiro, v.108, p.47-113, 1988. Disponível em:

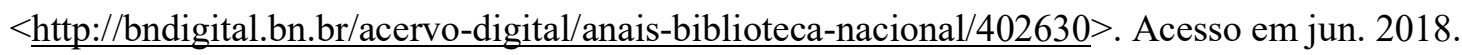

SAINT-HILAIRE, Auguste de. Segunda viagem do Rio de Janeiro a Minas Gerais e a São Paulo, 1822. (trad. Vivaldo di Moreira). Belo Horizonte: Ed. Itatiaia. São Paulo: Ed. da Universidade de São Paulo, 1974. [França, 1847]

. Viagem às nascentes do rio S. Francisco. Trad. Regina R. Junqueira. Belo Horizonte, Ed. Itatiaia; São Paulo: EDUSP, 1975. [França, 1847]

\section{LIVROS, ARTIGOS E TESES}

AB' SÁBER, Aziz. Os domínios de natureza no Brasil: potencialidades paisagísticas. 2.ed. São Paulo: Ateliê editorial, 2003. p.11-57.

AMANTINO, Marcia. O mundo das feras: Os moradores do sertão oeste de Minas Gerais - Século XVIII. São Paulo: Annablume, 2008.

ANDRADE, Antonio Luiz Dias de. Vale do Paraíba, sistemas construtivos. 1984 f. Dissertação (Mestrado em arquitetura) - Faculdade de Arquitetura e Urbanismo da Universidade de São Paulo, São Paulo.

ANDRADE, Manuel Correia de. A guerra dos Cabanos. Rio de Janeiro: Conquista, 1965. p.197-213.

. Geografia do quilombo. In: MOURA, Clóvis (org.). Os quilombos na dinâmica social do Brasil. Alagoas: EDUFAL, 2001. p.75-86.

ANJOS, Rafael Sanzio A. dos. Quilombos: Geografia africana - cartografia étnica, Territórios Tradicionais. Brasília: Mapas Editora \& Consultoria, 2009.

ASSUNÇÃO, Matthias Röhring. "Sustentar a Constituição e a Santa Religião Católica, amar a Pátria e o Imperador". Liberalismo popular e o ideário da Balaiada no Maranhão. In: DANTAS, Monica Duarte. Revoltas, motins, revoluções: homens livres pobres e libertos no Brasil do século XIX. São Paulo: Alameda, 2011. p.295-327

BARBOSA, Waldemar de Almeida. A decadência das Minas e a fuga da mineração. Belo Horizonte: Imprensa da Universidade Federal de Minas Gerais, 1971. p.13-125.

. Negros e quilombos em Minas Gerais. Belo Horizonte: 1972. p.31-53

BUENO, Beatriz P. S. Desenhando o Brasil: o saber cartográfico dos cosmógrafos e engenheiros militares da Colônia e do Império. In: COSTA, Antônio Gilberto. Roteiro prático de cartografia: da América portuguesa ao Brasil Império. Belo Horizonte: ed. UFMG, 2007. p.29-49

CARNEIRO, Edison. Singularidades dos Quilombos. In: MOURA. Os quilombos na dinâmica social do Brasil, Alagoas: EDUFAL, 2001. p.11-18.

CARVALHO, Marcus J. M. de. Um exército de indios, quilombolas e senhores de engenho contra os 'jacubinos': a Cabanada, 1832-1835. In: DANTAS, Monica Duarte. Revoltas, motins, revoluções: homens livres pobres e libertos no Brasil do século XIX. São Paulo: Alameda, 2011. p.167-200 
CHUVA, Márcia. Fundando a nação: a representação de um Brasil barroco, moderno e civilizado. Revista Topoi. Rio de Janeiro, v.4, n.7, p.313-333, jul/dez, 2003.

COELHO, José João Teixeira. Instrução para o governo da capitania de Minas [1780]. Transcrição e edição paleográfica por Cláudia Alves Melo. Belo Horizonte: Fundação João Pinheiro, Centro de Estudos Históricos e Culturais, 1994. p.137-163.

CORONA, Eduardo \& LEMOS, Carlos A. C. Dicionário da Arquitetura brasileira. São Paulo: Edart, 1972. p.362/ p.437-439.

COSTA, Emília Viotti da. A Abolição. São Paulo: Editora da Unesp, 2010.

COSTA; FURTADO; RENGER; SANTOS. Cartografia das Minas Gerais: Da capitania à fronteira. Belo Horizonte: Ed. UFMG, 2002.

COSTA, Lucio. Documentação Necessária. Revista do Serviço do Patrimônio Histórico e Artístico Nacional, Rio de Janeiro, n.1, p.31-39, 1937. Disponível em:

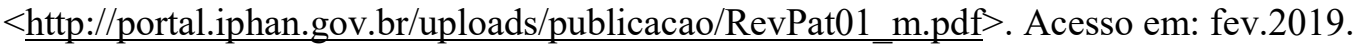

CUNHA, Marianno Carneiro da; VERGER, Pierre (fotos). Da Senzala ao Sobrado: arquitetura brasileira na Nigéria e República Popular do Benin. São Paulo: Nobel/Edusp, 1985. p.56-91.

DANTAS, Monica Duarte (org.). Revoltas, motins, revoluções: homens livres pobres e libertos no Brasil do século XIX. São Paulo: Alameda, 2011. p.511-563.

DENYER, Susan. African Traditional Architecture: an historical and geographical perspective. Londres: Heinemann, 1978.

FARIA, Maria Dulce de. Catálogo da Coleção Cartográfica e Iconográfica Manuscrita do Arquivo Histórico Ultramarino. Rio de Janeiro: Museu de Astrofísica e Ciências Afins, 2011. p.1720, 225-226. Disponível em:

$<$ http://objdigital.bn.br/objdigital2/acervo_digital/div_obrasgerais/drg1366355/drg1366355.pdf $>$

Acesso em out. 2019

FLEXOR, Maria Helena Ochi. Abreviaturas: Manuscritos dos séculos XVI ao XIX. $2^{\circ}$ ed. São Paulo: Arquivo do Estado, 1990.

FLORENTINO, Manolo; VIEIRA RIBEIRO, Alexandre; DOMINGUES DA SILVA, Daniel. Aspectos comparativos do tráfico de africanos para o Brasil: séculos XVIII e XIX. Revista Afro-Ásia da Universidade Federal da Bahia, Salvador, n. 31, p.83-126, 2004.

DOI: http://dx.doi.org/10.9771/aa.v0i31.21072. Disponível em:

https://portalseer.ufba.br/index.php/afroasia/article/view/21072. Acesso em: out. 2020.

FONSECA, Cláudia Damasceno. Arraiais e vilas d'el rei: espaço e poder nas Minas setecentistas. Tradução de Maria Juliana G. Teixeira. Belo Horizonte: Ed. UFMG, 2011. p.25-81

FREIRE, Karen. Materiais construtivos na África Subsaariana e sua influência sobre a arquitetura brasileira. In: $1^{\circ}$ Seminário em História e Fundamentos da Arquitetura e do Urbanismo/ Mestrado PPG AU USP, Caderno de Resumos/ org. Ana Castro. São Paulo: FAU/USP, 2018. p.45.

FREYRE, Gilberto. Mucambos do Nordeste: Algumas notas sobre o tipo de casa popular mais primitiva do nordeste do Brasil. Rio de Janeiro, SPHAN, s.d. [1937].

FRIDMAN, Fania. Donos do Rio em nome do rei: uma história fundiária da cidade do Rio de Janeiro. Rio de Janeiro: Jorge Zahar Ed.: Garamond, 1999. p.13-133/ p.216-217. 
GILROY, Paul. O Atlântico negro. trad. Patrícia Farias. São Paulo: Ed. 34; Rio de Janeiro: Univ. Candido Mendes, Centro de Estudos Afro-Asiáticos, 2001. [original em inglês de 1993]. p.09-25/ p.351-416.

GOMES, Flávio dos Santos. A hidra e os pântanos: mocambos, quilombos e comunidades de fugitivos no Brasil (séculos XVII-XIX). São Paulo: Ed. UNESP: Ed. Polis, 2005. p.358-395.

Quilombos/ Remanescentes de Quilombos. In: SCHWARCZ; GOMES (org.). Dicionário da escravidão e liberdade: 50 textos críticos. São Paulo: Companhia das Letras, 2018. p.367-373.

GUIMARÃES, Carlos Magno; LANNA, Ana Lúcia Duarte. Arqueologia de quilombos em Minas Gerais. Pesquisas: Antropologia, São Leopoldo, v.31, p.147-167, 1980.

GUIMARÃES, Carlos Magno; CARDOSO, Juliana. Arqueologia do quilombo: Arquitetura, Alimentação e Arte (Minas Gerais). In: MOURA (org.). Os quilombos na dinâmica social do Brasil. Alagoas: EDUFAL, 2001. p.35-58.

GUIMARÃES, Carlos Magno. Mineração, quilombos e Palmares: Minas Gerais do século XVIII. In: REIS; GOMES (org.). Liberdade por um fio: história dos quilombos no Brasil. São Paulo: Companhia das Letras, 1996. p.139-163.

Quilombos, classes, estado e cotidiano: Minas Gerais, século XVIII. 1999 f. Tese (Doutorado em História) - Faculdade de Filosofia, Letras e Ciências Humanas da Universidade de São Paulo, São Paulo.

HALL, Stuart. Da diáspora: Identidades e mediações culturais. trad. Adelaine Resende; org. Liv Sovik. $2^{\circ}$ edição. Belo Horizonte: ed. UFMG, 2013. [original em inglês de 2003]. p.27-55.

HERNANDEZ, Leila Maria Gonçalves Leite. A África na sala de aula: visita à história contemporânea. São Paulo: Selo Negro, 2005. p.17-44.

HOLANDA, Sérgio Buarque de. Caminhos e Fronteiras. Rio de Janeiro: Ed. José Olympio, 1957.

HORCH, Rosemarie E. Relação dos manuscritos da coleção J. F. de Almeida Prado. Catálogo do Instituto de Estudos Brasileiros da Universidade de São Paulo, 1966. p.I-V p.55-58.

JOFFROY, Thierry. Les pratiques de conservation traditionnelles em Afrique. Roma: ICCROM, 2005.p.74-79.

KANTOR, Íris. Cartografia e diplomacia: usos geopolíticos da informação toponímica (1750-1850). Anais do Museu Paulista, São Paulo, v.17, n.2, p.39-.61, jul.-dez. 2009.

KARASCH, Mary. Os quilombos do ouro na capitania de Goiás. In: REIS; GOMES (org.). Liberdade por um fio: história dos quilombos no Brasil. São Paulo: Companhia das Letras, 1996. p.240-262.

KI-ZERBO, Joseph. História da África Negra I. Sintra: Publicações Europa-América, 1972. p.29-32/ p.22-126 / p.139-141/ p.172-416.

LEMOS, Carlos A. C. A casa brasileira. São Paulo: Contexto, 1996.

LIRA, José Tavares Correia. "A construção discursiva da casa popular no Recife (década de 30)". Revista Análise Social, vol. XXIX (127), p.733-753, 1994.

MARQUESE, Rafael de Bivar. Moradia escrava na era do trafico ilegal: senzalas rurais no Brasil e em Cuba, c. 1830-1860. Anais do Museu Paulista, São Paulo: v.13, n.2, p.165-188, Jul - Dez. 2005.

Disponível em: 
$<$ http://www.scielo.br/scielo.php?script=sci_arttext\&pid=S010147142005000200006\&lng=en\&nrm=i so\&tlng $=\mathrm{pt}>$

MARTINS, Tarcísio José. Quilombo do Campo Grande: História de Minas que se devolve ao povo. Contagem: Santa Clara, 2008.

M'BOKOLO, Elikia. África Negra: história e civilizações v.1. Salvador: EDUFBA; São Paulo: Casa das Áfricas, 2009. p.11-14 / p.49-53 / p.168-180.

MELLO, Bruno César Euphrasio de. E o negro na arquitetura brasileira?. Arquitextos, São Paulo, ano 13, n. 145.01, Vitruvius, jun. 2012. Disponível em:

https://www.vitruvius.com.br/revistas/read/arquitextos/13.145/4372. Acesso em: out.2018.

MENESES, Maria Paula. O 'indígena' africano e o colono 'Europeu': A construção da diferença por processos legais. Revista E-cadernos CES: Identidades, cidadania e Estado, Lisboa, nº 7, 2010.

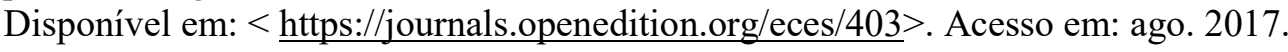

MORAES, Fernanda B. de. De arraiais, vilas e caminhos: a rede urbana das Minas coloniais. In: RESENDE; VILLALTA (org.). As Minas Setecentistas, vol.1. Belo Horizonte: Autêntica; Companhia do Tempo, 2007. p.55-85.

MOURA, Clóvis. Dicionário da Escravidão Negra no Brasil. São Paulo: Editora da Universidade de São Paulo, 2004. p.79/ p.277/ p.335-339.

A quilombagem com expressão de protesto radical. In: MOURA. Os quilombos na dinâmica social do Brasil. Alagoas: EDUFAL, 2001. p.103-115

MUNANGA, Kabengele. "Origem e Histórico de Quilombo na África”. Revista USP, São Paulo, n.28, p.56-63, mar.1996. Disponível em: http://www.revistas.usp.br/revusp/article/view/28364. Acesso em: dez. 2017.

NASCIMENTO, Abdias do. O Quilombismo: documentos de uma militância pan-africanista. Rio de Janeiro: ed. Vozes, 1980. p.11-30.

NASCIMENTO, Beatriz. O conceito de quilombo e a resistência cultural negra. Revista Afrodiáspora, Rio de Janeiro, ano 3, v. 6 e 7, p-41-49, abr./dez., 1985. Disponível em: $<$ http://ipeafro.org.br/acervo-digital/leituras/publicacoes-do-ipeafro/afrodiaspora-vol-6-e-7/>.

Acessado em: dez.2018.

PRATT, Mary. Os olhos do império: relatos de viagem e transculturação. Bauru, SP: EDUSC, 1999. p.23-75.

REIS, João José. Escravos e coiteiros no quilombo do Oitizeiro: Bahia, 1806. In: REIS e GOMES. Liberdade por um fio, 1996. p.332-372.

RESENDE, Maria Efigênia Lage de. Itinerários e interditos na territorialização das Geraes. In: RESENDE; VILLALTA (org.). As Minas Setecentistas, vol.1. Belo Horizonte: Autêntica; Companhia do Tempo, 2007. p.25-53.

RYKWERT, Joseph. A casa de Adão no paraíso: A idéia da cabana primitiva na História da Arquitetura. São Paulo: Perspectiva, 2009.

ROSS, Jurandyr L. Sanches. Os fundamentos da geografia da natureza. In: ROSS (org.). Geografia do

Brasil. 5ed. São Paulo: Edusp, 2005. p.32-65. 
RUSSEL-WOOD, A. J. R. Escravos e libertos no Brasil colonial. Tradução por Maria Beatriz Medina. Rio de Janeiro: Civilização Brasileira, 2005. [Oxford, Inglaterra, 1982]

SANTOS, Márcia Maria Duarte dos. Técnicas e elementos da cartografia da América portuguesa e do Brasil Império. In: COSTA, Antônio Gilberto. Roteiro prático de cartografia: da América portuguesa ao Brasil Império. Belo Horizonte: ed. UFMG, 2007. p.51-81.

SCHWARCZ, Lilia Moritz. O espetáculo das raças: cientistas, instituições e questão racial no Brasil - 1870-1930. São Paulo: Companhia das Letras, 1993. p.11-22/ p.43-66.

SCHWARTZ, Stuart. Cantos e Quilombos numa conspiração de escravos haussás: Bahia, 1814. In: REIS e GOMES. Liberdade por um fio, 1996. (p.373-406)

SILVA FILHO, Edson da; AMORIM FILHO, Oswaldo Bueno; CASTRO, José Flávio Morais. A contextualização histórica e geográfica dos quilombos do campo grande. In: I Simpósio Brasileiro de Cartografia Histórica, 2011, Paraty, Rio de Janeiro. Anais [...]. Disponível em:

$<$ https://www.ufmg.br/rededemuseus/crch/simposio/SILVA_FILHO_EDSON_ET_AL.pdf $>$. Acesso em: nov. 2019.

SILVA, Vagner Gonçalves . Candomblé e Umbanda: caminhos da devoção brasileira. São Paulo: Selo Negro, 2005. p.63-65.

SLENES, Robert W. Na senzala uma flor: esperanças e recordações na formação da família escrava, Brasil Sudeste, século XIX. Rio de Janeiro: Nova Fronteira, 1999. p.131-236.

SOUZA, Laura de Mello e. Desclassificados do ouro: a pobreza mineira no século XVIII. Rio de Janeiro: Ed. Graal. $4^{\circ}$ edição, 2004. p.77-130

Norma e conflito: aspectos da História de Minas no século XVIII. Belo Horizonte: Ed. $\overline{\mathrm{UFMG}}, 1999 . \mathrm{p} .83-137$

SOUZA, Marina de Mello. África e Brasil Africano. São Paulo: África, 2006. p.11-119.

VASCONCELLOS, Sylvio C. de. Arquitetura no Brasil - sistemas construtivos. Belo Horizonte: Escola de Arquitetura UFMG, 1958.

VENÂNCIO, Renato Pinto. Antes de Minas: fronteiras coloniais e populações indígenas. In: RESENDE; VILlALTA (org.). As Minas Setecentistas, vol.1. Belo Horizonte: Autêntica; Companhia do Tempo, 2007. p.87-102

VIOTTI DA COSTA, Emília. A abolição. 9º ed. São Paulo: UNESP, 2010.

WEIMER, Günter. Arquitetura Popular Brasileira. São Paulo: WMF Martins Fontes, 2005.p.115-151.

WILlETT, Frank. Arte Africana. São Paulo: Edições SESC; Imprensa Oficial do Estado de São Paulo, 2017. p.128-149.

\section{SITES}

ARAÚJO, Roberto Jorge Chaves. Normas técnicas para transcrição e edição de documentos manuscritos, sistematizadas pela Comissão de Sistematização e Redação do II Encontro Nacional de Normatização Paleográfica. São Paulo: 16 e 17 de setembro de 1993. Disponível em: $<$ http://www.al.pb.leg.br/elegispb/wpcontent/uploads/2013/08/TEXTO_DO_PROF._DR._ROBERTO_JORGE_CHAVES_ARAUJO1.pdf> Acesso em nov. 2018. 
Fundação Instituto Brasileiro de Geografia e Estatística - IBGE. Cartas e mapas. Disponíveis em: $<$ https://portaldemapas.ibge.gov.br/portal.php\#homepage>. Acesso em jun.2019.

Fundação Instituto Brasileiro de Geografia e Estatística - IBGE. Sinopse do Censo Demográfico 2010: Minas Gerais. Tabela 2.9. Disponível em:

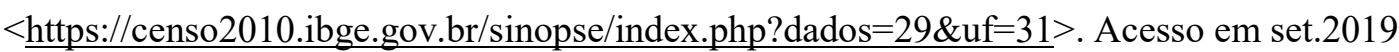

\section{VÍDEOS}

TAIPA DE MÃO, CASA DE CABLOCO. Direção de Luiz Bargamann.. São Paulo: Faculdade de Arquitetura e Urbanismo da Universidade de São Paulo, 1998. 19', português, colorido. Disponível em: <https://vimeo.com/51696268>. Acesso em: mar.2018.

TAIPA NO ESTADO DE SÃO PAULO. Direção de Lia Marcia Marinho. São Paulo: Ministério da Cultura, Secretaria do Audiovisual, Instituto Marlin Azul e Petrobras, 2008. 14', português, colorido. Disponível em: $<\mathrm{https} / /$ www.youtube.com/watch?v=qnQKaN86LmI $>$. Acesso em: mar.2018. 